UNIVERSIDADE DE SÃO PAULO

FACULDADE DE ECONOMIA, ADMINISTRAÇÃO E CONTABILIDADE DEPARTAMENTO DE CONTABILIDADE E ATUÁRIA

PROGRAMA DE PÓS-GRADUAÇÃO EM CONTROLADORIA E CONTABILIDADE

ADOÇÃO COMPLETA DAS IFRS NO BRASIL: QUALIDADE DAS DEMONSTRAÇÕES CONTÁBEIS E O CUSTO DE CAPITAL PRÓPRIO

Ricardo Luiz Menezes da Silva

Orientador: Alexsandro Broedel Lopes

SÃO PAULO

2013 
Prof. Dr. João Grandino Rodas

Reitor da Universidade de São Paulo

Prof. Dr. Reinaldo Guerreiro

Diretor da Faculdade de Economia, Administração e Contabilidade

Prof. Dr. Edgard Bruno Cornachione Jr.

Chefe do Departamento de Contabilidade e Atuária

Profa. Dra. Silvia Pereira de Castro Casa Nova

Coordenadora do Programa de Pós-Graduação em Controladoria e Contabilidade 


\section{ADOÇÃO COMPLETA DAS IFRS NO BRASIL: QUALIDADE DAS DEMONSTRAÇÕES CONTÁBEIS E O CUSTO DE CAPITAL PRÓPRIO}

Tese apresentada ao Departamento de Contabilidade e Atuária da Faculdade de Economia, Administração e Contabilidade da Universidade de São Paulo como requisito para a obtenção do título de Doutor em Ciências.

Orientador: Dr. Alexsandro Broedel Lopes

\section{Versão Corrigida}

(versão original disponível na Faculdade de Economia, Administração e Contabilidade)

\section{SÃO PAULO}




\section{FICHA CATALOGRÁFICA}

Elaborada pela Seção de Processamento Técnico do SBD/FEA/USP

\section{Silva, Ricardo Luiz Menezes da}

Adoção completa das IFRS no Brasil: qualidade das demonstrações contábeis e o custo de capital próprio / Ricardo Luiz Menezes da Silva. - São Paulo, 2013.

$217 \mathrm{p}$.

Tese (Doutorado) - Universidade de São Paulo, 2013.

Orientador: Alexsandro Broedel Lopes.

1. Contabilidade societária 2. Custo de capital 3. Informações contábeis 4.Mercado de capitais I. Universidade de São Paulo. Faculdade de Economia, Administração e Contabilidade. II. Título.

CDD -657.92 
À minha família.

À minha noiva Paula Nardi. 
Agradeço imensamente à Profa. Dra. Silvia Pereira de Castro Casa Nova, que tornou possível a realização de um sonho.

Ao Prof. Dr. Alexsandro Broedel Lopes, pelos ensinamentos e orientação, ao longo do desenvolvimento da pesquisa.

Aos professores, Dr. Eliseu Martins, Dr. Guillermo Braunbeck, Dr. Ariovaldo dos Santos, Dr. Fernando Dal Ri Murcia, Dra. Flávia Zóboli Dalmácio, Dr. Gilberto Martins, Dr. Gerlando Augusto Sampaio Franco de Lima, Dra. Joanília Neide de Sales Cia, Dr. Bruno Salotti, Dr. Arthur Ridolfo, Dr. Alexandre Assaf Neto, Dr. Luís Eduardo Afonso, Dr. Edgard Bruno Cornacchione Junior, Dra. Tânia Regina Sordi Relvas e demais, pelas inestimáveis contribuições.

Aos amigos, Alex Mussoi Ribeiro, Carlos Henrique Silva do Carmo, Alexandre Gonzales, Rafael Sasso, Marcelo Barroso, Tatiana Albanez, Nelma Zubek Valente, Fernando Chiqueto, Kelly Rodrigues, Manoel Farias, Ana Paula Capuano da Cruz, Anderson Feitosa Pereira, Eric Aversari Martins, José Elias Almeida, Josué Braga, Ivan Canan, Patrícia Oda, Vinícius Simmer de Lima, Aziz Xavier Beiruth e demais, pela convivência e ajuda.

Aos professores do departamento de contabilidade da FEA/RP-USP, pelo apoio, em especial, Dra. Maísa de Souza Ribeiro e Dr. Sílvio Hiroshi Nakao, pela cooperação e ensinamentos.

À minha noiva Paula Nardi pelo apoio e paciência ao longo do curso de doutorado. Nos momentos mais difíceis deste desafio, a minha fonte de inspiração foi você.

Aos meus pais, irmãos, parentes e amigos que foram compreensíveis nas situações em que não pude ajudar.

Aos funcionários da FEA, sempre prestativos e muito pacientes.

À Coordenação de Aperfeiçoamento de Pessoal de Nível Superior - CAPES, pelo apoio financeiro. 


\section{RESUMO}

O objetivo desta tese resume-se em investigar o impacto da adoção completa das IFRS na qualidade das demonstrações contábeis e no custo de capital próprio das empresas brasileiras de capital aberto no período 2000-2011. Para isso, dada a multidimensionalidade da qualidade da informação contábil, adotou-se o método denominado portfolio approach, que restringe-se a análise de: i) gerenciamento de resultado (GR); ii) conservadorismo condicional; iii) relevância; e iv) tempestividade. Ademais, pressupondo um aumento no conteúdo informacional após adoção completa, que, por sua vez, contribui para reduzir a informação assimétrica no mercado de capitais, conjecturou-se uma redução no custo de capital próprio, em vista da alocação mais eficiente de recursos. Entre as justificativas da pesquisa, pode-se citar o modelo híbrido de convergência adotado pelo Brasil, que é composto de duas etapas: a primeira em 2008 e 2009 com a adoção parcial das IFRS, e a segunda a partir de 2010 com a adoção completa das normas, despertando interesse em verificar as consequências econômicas oriundas da mudança de GAAP. A originalidade desse trabalho reside na análise do período de adoção completa (2010 e 2011), que compreende transações econômicas antes não incorporadas, quando da análise da adoção parcial (LIMA, 2010; LIMA, 2011), portanto analisou-se, de maneira conjunta, dois benefícios associados às IFRS intensamente discutidos na literatura. O estudo empírico baseou-se em abordagens de dados em painel e diferenças em diferenças, sendo que o GMM Sistêmico foi utilizado para avaliar a robustez dos resultados. A amostra foi definida a partir da carteira teórica do IBrX-100, além de 30 empresas que adotaram as IFRS antecipadamente, caracterizando uma amostra não probabilística. Os resultados revelam que os accruals discricionários estimados pelo modelo de Kang e Sivaramakrishnan (1995), proxy para GR, diminuíram no período da adoção completa. Além disso, observa-se um aumento no conservadorismo condicional mensurado pelos modelos de Basu (1997) e Ball e Shivakumar (2005). Os modelos de relevância e tempestividade, baseados em Easton (1999), revelam um aumento em ambas às dimensões da qualidade da informação contábil. Na análise de curto prazo, o estudo de evento fornece indícios de que o mercado reagiu quando da divulgação dos relatórios contábeis em IFRS, permitindo concluir que a informação foi refletida no preço das ações. Embora a tempestividade seja constatada, os modelos baseados em Horton e Serafeim (2009) não indicam relevância para o curto prazo. Apesar disso, aceita-se a hipótese de aumento na qualidade da informação contábil após adoção completa das IFRS. Por outro lado, os modelos para análise do custo de capital próprio, baseados em Francis et al (2005) e Li (2010), sugerem uma redução no custo de capital em torno de 7 pontos-base das empresas que adotaram obrigatoriamente as IFRS a partir de 2010, permitindo a aceitação da hipótese de redução do custo de capital próprio. Neste sentido, esta tese apresenta evidências empíricas de que a maior qualidade das demonstrações contábeis em IFRS implica em redução do custo de capital próprio, coerente com Lopes e Alencar (2010). A maior divulgação proporcionada pela adoção completa das IFRS pode ser explicada pelo registro de transações anteriormente não contabilizadas. Estes achados implicam que a informação contábil em IFRS pode ser mais útil para os diversos usuários da contabilidade, como os analistas, os quais necessitam de números contábeis mais informativos, com o propósito de avaliar risco e apresentar estimativas mais precisas. Além disso, a informação contábil mais relevante e tempestiva pode ser útil para os acionistas que buscam avaliar o desempenho econômico-financeiro das empresas, contribuindo para uma alocação de recursos no mercado mais eficiente. Por último, estas evidências podem fortalecer a posição do IASB nas atuais discussões sobre o processo de convergência, visto que os resultados corroboram as declarações de representantes do IASB acerca das consequências econômicas advindas da adoção das IFRS. 


\begin{abstract}
The purpose of this thesis is to investigate the impact of the IFRS full adoption in the quality of the financial statements and the equity cost of Brazilian public companies in the period of 2000-2011. Therefore, given the multidimensionality of the accounting information quality, the portfolio approach was adopted, which is restricted to the analysis of: i) earnings management (EM); ii) conditional conservatism; iii) value-relevance; and iv) timeliness. Moreover, assuming an increase in information after full adoption, this contributes to reduce the asymmetric information in the capital market. It is possible to conjecture a reduction in the cost of capital given the more efficient allocation of resources. Among the justifications of this research, it can be cited the hybrid model of convergence adopted in Brazil, which is composed of two stages: the first in 2008 and 2009 with partial IFRS adoption and the second starting in 2010 with full standards adoption, which aroused interest to verify the economic consequences arising from the change in GAAP. The originality of this work lies in analyzing the full adoption period (2010 and 2011), including economic transactions which were not previously incorporated in the partial adoption examination (LIMA, 2010; LIMA, 2011). Therefore, a joint analysis was made of the two benefits associated with IFRS intensively discussed in the literature. The empirical study was based on approach panel data and differences in differences; and the System GMM was used to evaluate the robustness of the results. The sample was defined from the theoretical portfolio $\mathrm{IBrX}-100$, as well as 30 companies that adopted IFRS in advance, setting a non-probabilistic sample. The results show that discretionary accruals estimated by the model Kang and Sivaramakrishnan (1995), proxy for EM, decreased during the full adoption. Moreover, there is an increase in conditional conservatism measured by the models Basu (1997) and Ball and Shivakumar (2005). The models of value-relevance and timeliness, based on Easton (1999), show an increase in both dimensions of the accounting information quality. In the short-term analysis, the event study provides evidence that the market reacted in the disclosure of financial reporting under IFRS, allowing to conclude that the information reflected in the stock prices. Although the timeliness is verified, the models based on Horton and Serafeim (2009) observed no relevance for short term. Nevertheless, it is accepted the hypothesis of an increase in the accounting information quality after IFRS full adoption. On the other hand, the models for analysis of equity cost of capital, based on Francis et al (2005) and Li (2010) suggest a reduction in the cost of capital around 7 basis points of companies that adopted IFRS mandatorily starting in 2010 which allows the acceptance of the hypothesis of reducing the equity cost. Therefore, this thesis presents empirical evidence that, the highest quality of financial statements according to IFRS implies in low cost of capital which is consistent with Lopes and Alencar (2010). The greatest disclosure provided by IFRS full adoption can be explained based on registers of previously unaccounted transactions. These findings imply that the accounting information under IFRS may be more useful for many accounting users such as analysts, who require more informativeness accounting numbers, in order to assess risk and provide more accurate estimates. Also, the accounting information more relevant and timely can be useful for shareholders that seek to evaluate the financial performance of companies, contributing to a more efficient allocation of resources in the market. Finally, these evidences may strengthen the position of the IASB in current discussions regarding the convergence process, since the results corroborate the IASB representative's declarations concerning the economic consequences resulting from the IFRS adoption.
\end{abstract}




\section{SUMÁRIO}

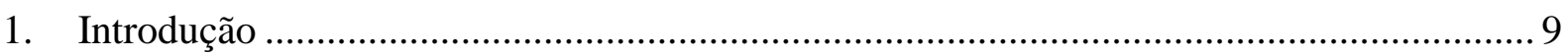

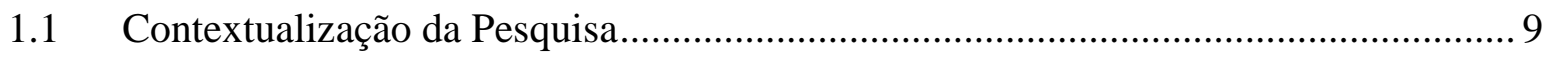

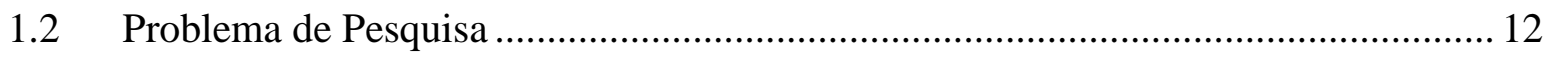

1.3 Tese

1.4 Desenvolvimento das Hipóteses de Pesquisa ...................................................... 13

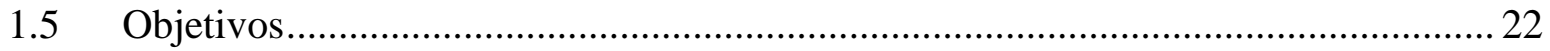

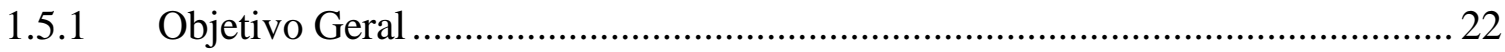

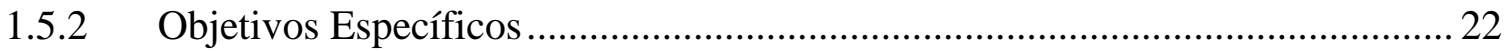

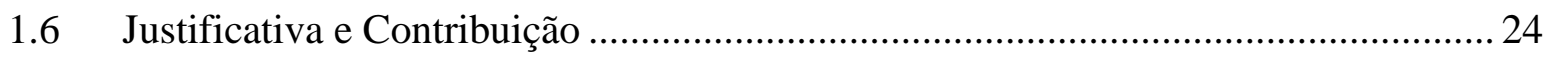

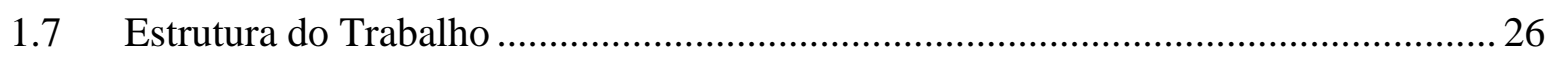

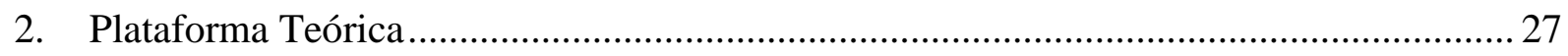

2.1 Mercado de Capitais e Informação Contábil ........................................................... 27

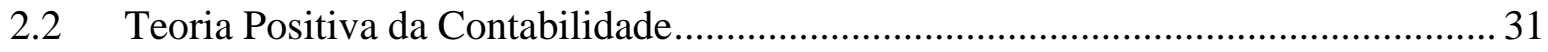

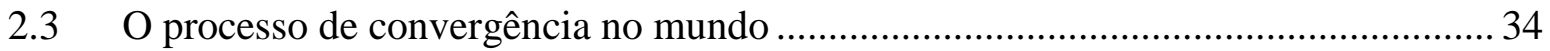

2.4 O processo de convergência no Brasil........................................................................... 39

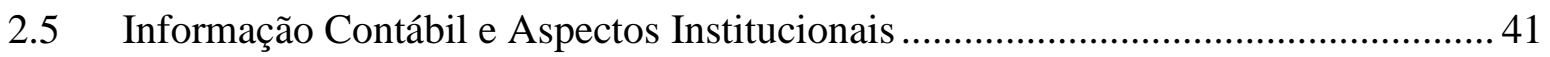

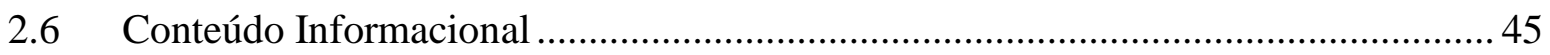

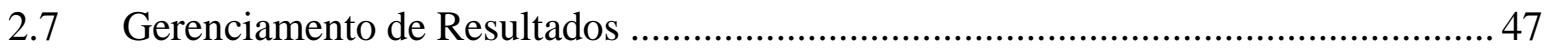

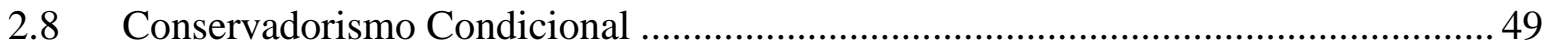

2.9 Relevância da Informação Contábil ....................................................................... 51

2.9.1 Modelos de relevância e tempestividade: fundamentação, evidências empíricas e

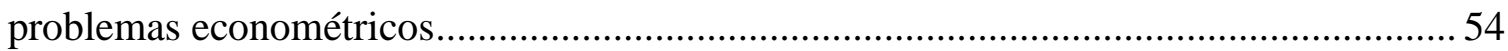

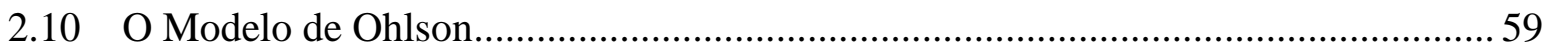

2.11 Governança Corporativa no Brasil e sua relação com a Qualidade da Informação Contábil

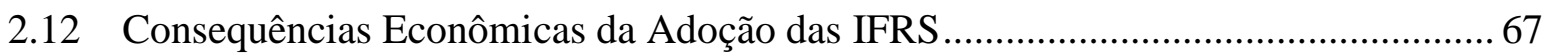

2.13 Quadro resumo das consequências econômicas nos países adotantes das IFRS ....... 73

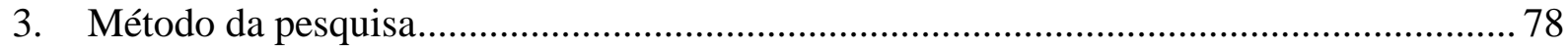

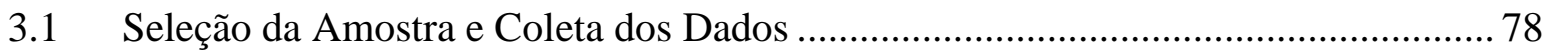

3.2 Especificação do Modelo de Diferenças em Diferenças para Custo de Capital........ 81

3.3 A Aplicação do Portfolio Approach para Conteúdo Informacional ........................... 83

3.3.1 Especificação dos Modelos de Gerenciamento de Resultados........................... 84

3.3.2 Especificação dos Modelos de Conservadorismo Condicional...........................93 
3.3.3 Especificação do Modelo de Relevância da Informação Contábil......................97

3.3.4 Especificação do Modelo de Tempestividade da Informação Contábil ..............97

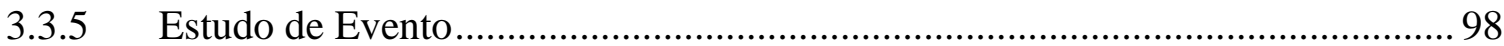

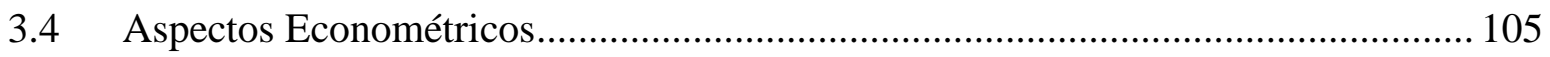

3.4.1 Estimação dos modelos de dados em painel .................................................... 105

3.4.2 Modelo de Diferenças em Diferenças ................................................................. 109

3.5 Brazilian Corporate Governance Index - BCGI.................................................. 113

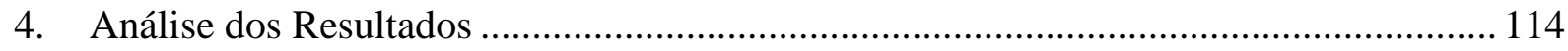

4.1 Análise do Custo de Capital Próprio pelo Modelo de Diferenças em Diferenças ... 114

4.2 Análise do Gerenciamento de Resultados .............................................................. 118

4.2.1 Gerenciamento de Resultados segundo Barth et al (2006) .............................. 119

4.2.2 Gerenciamento de Resultados segundo o Modelo TEOH............................... 123

4.2.3 Gerenciamento de Resultados segundo o Modelo JM ..................................... 126

4.2.4 Gerenciamento de Resultados segundo o Modelo KS .................................... 129

4.2.5 Gerenciamento de Resultados: a relação entre accruals discricionários e a

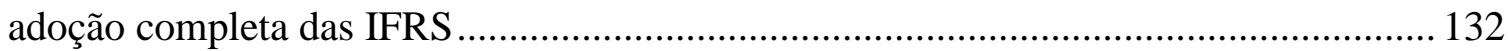

4.3 Análise do Conservadorismo Condicional .............................................................. 134

4.3.1 O reconhecimento oportuno de perdas segundo Basu (1997).......................... 134

4.3.2 Componentes transitórios de ganhos e perdas segundo Basu (1997)............... 138

4.3.3 O reconhecimento oportuno de perdas segundo Ball e Shivakumar (2005) .... 141

4.4 Análise da Relevância da Informação Contábil ..................................................... 144

4.5 Análise da Tempestividade da Informação Contábil............................................. 150

4.6 Achados do Estudo de Evento na Adoção Inicial das IFRS .................................... 152

4.6.1 Análise Gráfica e Teste dos Sinais .................................................................... 153

4.6.2 Análise da Relevância e da Tempestividade na Janela de Evento .................... 161

4.7 A Relação entre Custo de Capital e Qualidade da Informação Contábil.................. 163

4.8 Análise Adicional e Testes de Robustez................................................................ 166

4.8.1 Modelo de Diferenças em Diferenças para Custo de Capital Próprio............... 166

4.8.2 Estimativas pelo GMM Sistêmico.................................................................... 167

4.8.2.1 Gerenciamento de Resultados ................................................................ 169

4.8.2.2 Reconhecimento oportuno de perdas segundo Basu (1997)........................ 170

4.8.2.3 Relevância da Informação Contábil .......................................................... 171

4.8.2.4 Tempestividade da Informação Contábil.................................................... 172

4.8.2.5 Custo de Capital Próprio e Qualidade da Informação Contábil .................... 173 


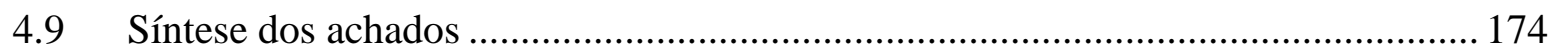

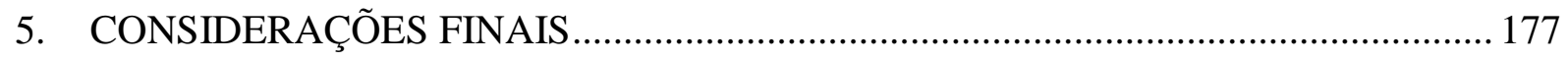

5.1 Um Resumo das Evidências Empíricas .................................................................... 177

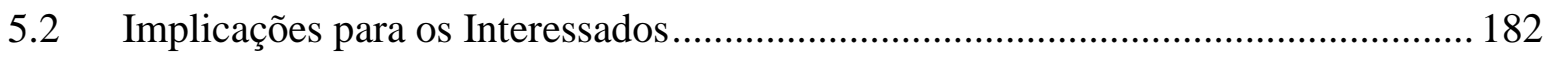

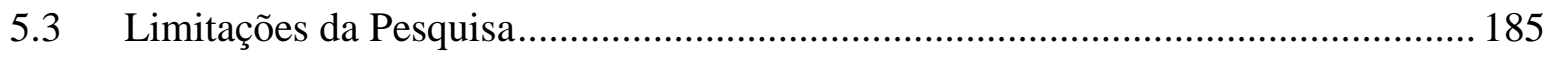

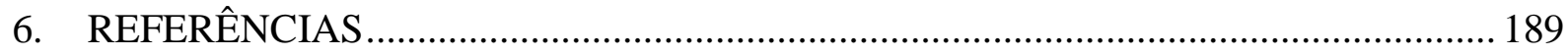

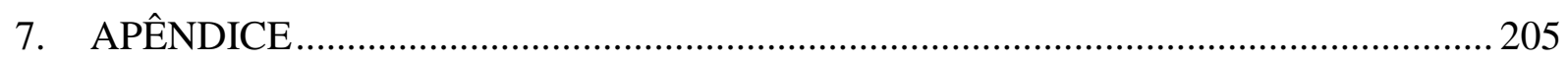

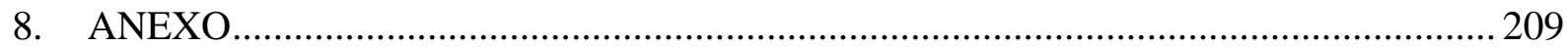




\section{LISTAS DE ABREVIATURAS E SIGLAS}

AAA FASC - American Accounting Association's Financial Accounting Standards Committee

AD - Accruals Discricionários

ADR - American Depositary Receipt

AEG - Abnormal Earnings Growth

AGAAP - Australian Generally Accepted Accounting Principles

AND - Accruals não Discricionários

AT - Accruals Totais

ATE - Average Treatment Effect

BCGI - Brazilian Corporate Governance Index

BM\&FBOVESPA - Bolsa de Mercadorias e Futuros e Bolsa de Valores de São Paulo

BNDES - Banco Nacional de Desenvolvimento Econômico e Social

BRGAAP - Brazilian Generally Accepted Accounting Principles

CA - Conselho de Administração

CAPM - Capital Asset Pricing Model

CAR - Cumulative Abnormal Returns

CPC - Comitê de Pronunciamentos Contábeis

CVM - Comissão de Valores Mobiliários

DAR - Daily Abnormal Returns

DD - Modelo de Diferenças em Diferenças

DC - Demonstrações Contábeis

EBIT - Earnings Before Interest and Taxes

EMH - Efficient Markets Hypothesis

EQ - Earnings Quality

FASB - Financial Accounting Standards Board

GAAP - Generally Accepted Accounting Principles

GMM - Generalized Method of Moments

GR - Gerenciamento de Resultado

HK GAAP - Hong Kong Generally Accepted Accounting Principles

IAS - International Accounting Standards

IASB - International Accounting Standard Board

IASC - International Accounting Standard Committee 
LISTAS DE ABREVIATURAS E SIGLAS

IBGC - Instituto Brasileiro de Governança Corporativa

IFRS - International Financial Reporting Standards

IOSCO - International Organization of Securities Commissions

JM - Jones Modificado

KS - Kang e Sivaramakrishnan

LM - Lagrange Multiplier

MQG - Mínimos Quadrados Generalizados

MQO - Mínimos Quadrados Ordinários

NYSE - New York Stock Exchange

PCB - Pronunciamento Conceitual Básico

PE - Price-Earnings

PEG - Ratio Divided by Short-term Earnings Growth

POLS - Pooled Ordinary Least Squares

PVED - Present Value of Expected Dividends

RIV - Residual Income valuation Model

SA - Sociedade Anônima

SEC - Securities and Exchange Commission

USGAAP - United States Generally Accepted Accounting Principles 


\section{LISTA DE QUADROS}

Quadro 1 - Quadro resumo das principais evidências empíricas decorrentes da adoção das normas internacionais de contabilidade .74

Quadro 2 - Brazilian Corporate Governance Index - BCGI 209 


\section{LISTA DE TABELAS}

Tabela 1 - Pesquisas na área de mercado de capitais e contabilidade .....................................2 29

Tabela 2 - Países e seus respectivos planos de convergência para as IFRS ............................ 37

Tabela 3 - Procedimentos para seleção da amostra final .................................................... 79

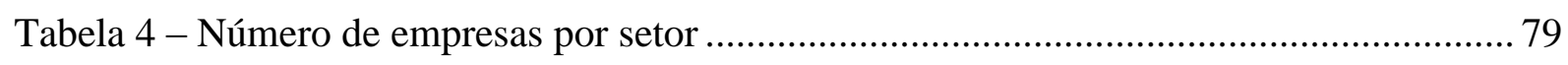

Tabela 5 - Estatística descritiva das variáveis $r_{P E G}, S I Z E, R E T V A R, L E V$, ADR e BCGI para o

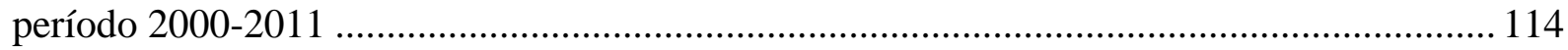

Tabela 6 - Correlação entre as variáveis $r_{P E G}$, SIZE, RETVAR e LEV ................................... 116

Tabela 7 - Estimativas geradas para a equação 15 - custo de capital próprio pelo modelo de diferenças em diferenças

Tabela 8 - Estatística descritiva das variáveis $\triangle N I, M V E$, GROWTH, EISSUE, DEBT, DISSUE e TURN para o período 2000-2011

Tabela 9 - correlação entre as variáveis $\triangle N I, M V E$, GROWTH, EISSUE, DEBT, DISSUE e TURN. 120

Tabela 10 Estimativas geradas para o modelo adaptado de Barth et al (2006) 121

Tabela 11 - Estatística descritiva das variáveis do modelo TEOH, para o período 2000-2011

Tabela 12 - Correlação entre as variáveis do modelo TEOH................................................. 124

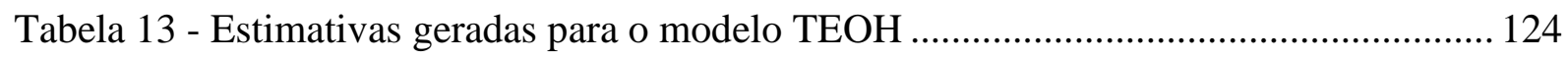

Tabela 14 - Estatística descritiva das variáveis do modelo JM, para o período 2000-2011 .. 126

Tabela 15 - Correlação entre as variáveis do modelo JM .................................................... 127

Tabela 16 - Estimativas geradas para o modelo JM ........................................................... 128

Tabela 17 - Estatística descritiva das variáveis do modelo KS, para o período 2000-2011 .. 130

Tabela 18 - Correlação entre as variáveis do modelo KS ..................................................... 130

Tabela 19 - Estimativas geradas para o modelo KS .......................................................... 131

Tabela 20 - correlação entre as variáveis $A D_{K S}, A D_{T E O H}, A D_{J M}, C F$, SIZE e DEBT ............... 133

Tabela 21 - Estimativas geradas para a equação 31, baseada em Tendeloo e Vanstraelen (2005)

Tabela 22 - Estatística descritiva das variáveis $R E T, D R, D R * R E T$ e $A D R$ para o período $2000-2011$ 135

Tabela 23 - Correlação entre as variáveis EARN, RET e DR*RET. 135

Tabela 24 - Estimativas geradas para o modelo de reconhecimento oportuno de perdas

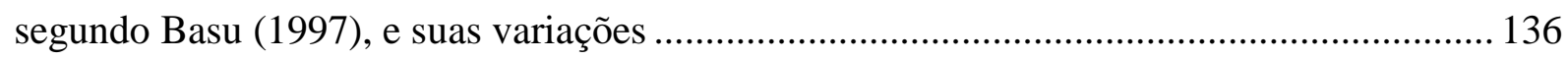

Tabela 25 - Estatística descritiva da variável $\triangle E A R N$ para o período 2000-2011 ................. 139 
Tabela 26 - Estimativas geradas para o modelo de componentes transitórios de ganhos e perdas segundo Basu (1997), e suas variações...................................................................... 140

Tabela 27 - Estatística descritiva das variáveis AT e FCO, para o período 2000-2011 ......... 142 Tabela 28 - Estimativas geradas para o modelo de reconhecimento oportuno de perdas segundo Ball e Shivakumar (2005), e suas variações

Tabela 29 - Estatística descritiva das variáveis do modelo de relevância, para o período 20002011 145

Tabela 30 - Correlação entre as variáveis do modelo de relevância 147

Tabela 31 - Estimativas geradas para o modelo de relevância, e suas variações 148

Tabela 32 - Estimativas geradas para o modelo de tempestividade, e suas variações ..... 150

Tabela 33 -Estatísticas descritivas para as variáveis lucro líquido, patrimônio líquido e CAR. 5+5 segmentadas nos grupos TODAS, VOLUNTÁRIAS e OBRIGATÓRIAS.

Tabela 34 - Teste de sinais para as séries de retorno anormal 160

Tabela 35 - Estimativas geradas para avaliar a tempestividade da informação contábil na janela de evento 162

Tabela 36 - Estimativas geradas para avaliar a relevância da informação contábil na janela de evento

Tabela 37 - Estimativas geradas para avaliar a relação entre custo de capital próprio e gerenciamento de resultado conforme equação 58 165

Tabela 38 - Estimativas geradas para a equação 15 - custo de capital próprio pelo modelo de diferenças em diferenças, excluindo 2009 e 2010. 167

Tabela 39 - Estimativas geradas para o modelo KS: estimador GMM Sistêmico 169

Tabela 40 - Estimativas geradas para a equação 31, baseada em Tendeloo e Vanstraelen (2005): estimador GMM Sistêmico. 170

Tabela 41 - Estimativas geradas para o modelo de reconhecimento oportuno de perdas segundo Basu (1997): estimador GMM Sistêmico 171

Tabela 42 - Estimativas geradas para o modelo de relevância: estimador GMM Sistêmico 172 Tabela 43 - Estimativas geradas para o modelo de tempestividade: estimador GMM Sistêmico 173

Tabela 44 - Estimativas geradas para avaliar a relação entre custo de capital próprio e gerenciamento de resultado conforme equação 59: estimador GMM Sistêmico 174

Tabela 45 - Síntese dos resultados para as hipóteses de pesquisa ........................................ 175

Tabela 46 - Empresas da amostra e suas respectivas datas de adoção inicial das IFRS ....... 205

Tabela 47 - Teste de raiz unitária de Fisher. 207 


\section{LISTA DE GRÁFICOS}

Gráfico 1 - Comportamento do custo de capital próprio médio $\left(\mathrm{R}_{\mathrm{PEG}}\right)$ para os grupos de controle (empresas que adotaram IFRS antecipadamente) e tratamento (empresas que adotaram IFRS obrigatoriamente) no período 2000-2011 .................................................... 112

Gráfico 2 - Variância dos resíduos gerados pela equação 39 ................................................ 122

Gráfico 3 - Accruals discricionários estimados pelo modelo TEOH. ................................. 125

Gráfico 4 - accruals discricionários estimados pelo modelo JM e TEOH............................. 129

Gráfico 5 - Accruals discricionários estimados pelos modelos JM, TEOH e KS.................. 132

Gráfico 6 - Média do lucro líquido e do patrimônio líquido ao longo de 2000-2011 plotada

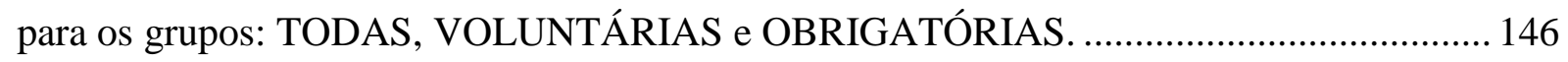

Gráfico 7 - $\overline{C A R}$ representa a agregação do retorno anormal acumulado no período $t$ para todas as ações $(n=101)$ e para aquelas que possuíam ADR $\left(\mathrm{n}_{1}=25\right)$ na janela de evento.

Gráfico $8-\overline{D A R_{t}}$ corresponde à média dos retornos anormais no período $t$ para todas as ações $(\mathrm{n}=101)$ e para aquelas que possuíam $\operatorname{ADR}\left(\mathrm{n}_{1}=25\right)$ na janela de evento.

Gráfico $9-\overline{C A R}$ representa a agregação do retorno anormal acumulado no período $\mathrm{t}$ para as ações que apresentaram um ajuste positivo no resultado $\left(\mathrm{n}_{2}=70\right)$, e para aquelas que apresentaram um ajuste negativo $\left(\mathrm{n}_{3}=31\right)$ na janela de evento; o ajuste de conciliação corresponde à diferença entre os lucros em IFRS e BRGAAP, exigida pelo CPC 37 quando da adoção inicial das IFRS.

Gráfico 10 - $\overline{D A R_{t}}$ corresponde à média dos retornos anormais no período $t$ para as ações que apresentaram um ajuste positivo no resultado $\left(\mathrm{n}_{2}=70\right)$, e para aquelas que apresentaram um ajuste negativo $\left(n_{3}=31\right)$ na janela de evento; o ajuste de conciliação corresponde à diferença entre os lucros em IFRS e BRGAAP, exigida pelo CPC 37 quando da adoção inicial das IFRS.

Gráfico 11 - $\overline{C A R}$ representa a agregação do retorno anormal acumulado no período $t$ para as ações de empresas que adotaram de forma voluntária as IFRS $\left(\mathrm{n}_{4}=27\right)$, e para aquelas que adotaram obrigatoriamente $\left(\mathrm{n}_{5}=74\right)$ na janela de evento. 158 Gráfico 12 - $\overline{D A R_{t}}$ corresponde à média dos retornos anormais no período $\mathrm{t}$ para as ações de empresas que adotaram de forma voluntária as IFRS $\left(n_{4}=27\right)$, e para aquelas que adotaram obrigatoriamente $\left(\mathrm{n}_{5}=74\right)$ na janela de evento 159 


\section{LISTA DE ILUSTRAÇÃO}

Ilustração 1 - Esquema das hipóteses de pesquisa sobre as dimensões da qualidade da

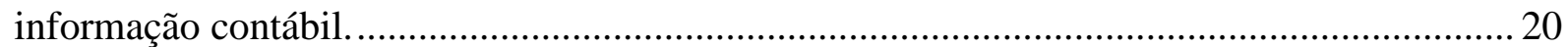

Ilustração 2 - esquema de hipótese de pesquisa sobre custo de capital. ................................. 22

Ilustração 3- Determinantes da Qualidade Contábil ............................................................ 45

Ilustração 4 - Visão esquemática da relação entre conteúdo informacional, estrutura conceitual e características qualitativas das demonstrações contábeis. 46 


\section{INTRODUÇÃO}

\subsection{Contextualização da Pesquisa}

Esta tese fornece evidências empíricas que sugerem um aumento na qualidade da informação contábil após adoção completa das International Financial Reporting Standards - IFRS e, consequentemente, redução no custo de capital próprio. Este trabalho se destaca dos demais, pois a qualidade das demonstrações contábeis é investigada a partir de quatro dimensões da qualidade, sendo elas, gerenciamento de resultados, conservadorismo condicional, relevância e tempestividade, as quais estão convergindo em termos de utilidade da contabilidade. Além disso, embora haja evidências empíricas para a qualidade da informação contábil (LIMA, 2010) e custo de capital próprio (LIMA, 2011) para o caso brasileiro, estes achados são válidos para a adoção parcial das normas (2008 e 2009), sendo que o período de adoção completa (2010 e 2011) carecia de investigação. Outra justificativa para estudar tal período repousa nas próprias demonstrações contábeis divulgadas, as quais compreendem transações econômicas antes não incorporadas, visto que a adoção parcial restringiu-se a alguns pronunciamentos contábeis. Logo, esta tese apresenta um diagnóstico sobre a qualidade da informação contábil full IFRS, e seu efeito no custo de capital próprio das empresas brasileiras de capital aberto, concatenando dois benefícios associados às IFRS intensamente discutidos na literatura, mas não de maneira conjunta. Estes aspectos, juntamente com os outros citados, caracterizam a originalidade da pesquisa.

As consequências econômicas observadas para o caso brasileiro remontam os principais incentivos que levaram ao desenvolvimento de um padrão de normas contábeis para diversos países. No final da primeira metade do século XX, em um cenário de crescente internacionalização e liberalização dos mercados de capital e crédito, houve um aumento no número de transações entre países, os quais possuíam sistemas contábeis diferentes. Naturalmente surgiu uma preocupação por parte dos agentes de mercado, principalmente os investidores, ao observarem demonstrações contábeis tão distintas, o que impedia ou dificultava a comparação das demonstrações entre países.

Em resposta a esta dificuldade, um grupo de países se juntou com o objetivo de produzir um conjunto de normas contábeis internacionais, assegurando aos investidores relatórios contábeis transparentes e comparáveis. Este grupo deu origem ao International Accounting 
Standard Committee (IASC), fundado em 1973. Desde então, o processo para elaboração das normas internacionais tem sofrido uma evolução substancial, culminando na reestruturação do IASC para o International Accounting Standard Board (IASB). Esta organização busca desenvolver um conjunto único de pronunciamentos contábeis de alta qualidade, compreensíveis, exequíveis e aceitáveis globalmente. Mais de 120 países já adotam as International Financial Reporting Standards (IFRS) e muitos outros estão planejando migrar para o conjunto de normas internacionais.

Desde a década de 90 a Comissão de Valores Mobiliários (CVM) e outras entidades têm emitido regras contábeis voltadas para as normas internacionais de contabilidade. Em 2008, a CVM emitiu a Deliberação no. 565 que aprovou o Pronunciamento Técnico CPC 13, com o objetivo de regular a introdução de um novo conjunto de princípios e práticas contábeis com base nas IFRS. Para alcançar este objetivo o CPC 13, após aprovação da CVM, exigiu que as empresas adotassem a Lei $n^{\circ} 11.638 / 07$ e a Medida Provisória n 449/08 ${ }^{1}$, além das normas contábeis emitidas pelo Comitê de Pronunciamentos Contábeis (CPC). Estas normas tiveram como principal objetivo atualizar a legislação societária brasileira para possibilitar o processo de convergência das práticas contábeis adotadas no Brasil. Assim, o CPC emitiu 14 pronunciamentos $^{2}$ técnicos em correlação ${ }^{3}$ às IFRS até 2008, os quais foram aplicados pelas empresas nas demonstrações contábeis de 2008 e 2009.

Em dezembro de 2010, a deliberação CVM nº 647 foi emitida e exigiu a adoção do CPC 37, intitulado “Adoção Inicial das Normas Internacionais de Contabilidade”. Este CPC é baseado na IFRS 1, cujo objetivo é nortear a entidade que adota as IFRS pela primeira vez, e, no caso brasileiro, exigiu, após aprovação da CVM, a aplicação de todos os CPCs vigentes em 2010 nas demonstrações contábeis consolidadas. Portanto, a partir desse exercício social, pode-se dizer que as demonstrações contábeis consolidadas das empresas brasileiras de capital aberto são elaboradas com base nas IFRS.

Neste sentido, o processo de transição das normas contábeis brasileiras ou Brazilian Generally Accepted Accounting Principles (BRGAAP) para as normas contábeis internacionais ou IFRS se deu em duas etapas, diferentemente dos países da União Europeia,

\footnotetext{
${ }^{1}$ Atual Lei no $11.941 / 09$.

${ }^{2}$ Os 14 CPCs são: 01, 02, 03, 04, 05, 06, 07, 08, 09, 10, 11, 12, 13 e 14. Disponível em 〈www.cpc.org.br〉.

${ }^{3}$ Exceto o CPC 09 - Demonstração do Valor Adicionado que não tem uma norma internacional correspondente.
} 
que adotaram obrigatoriamente todas as IFRS/IAS a partir de 2005. No Brasil, a primeira se deu em 2008 e 2009 com a adoção parcial das IFRS, e a segunda a partir de 2010 com a adoção completa das normas internacionais. Como não há relatos de casos similares, o processo de convergência brasileiro pode ser caracterizado como único, despertando interesse em investigar se as consequências econômicas identificadas em outros casos de adoção se aplicam ao Brasil. Outra questão que merece destaque é o tratamento fiscal, sendo que o Regime Tributário de Transição (RTT) foi instituído pela medida provisória 449/08, visando a neutralidade tributária.

O processo de convergência para as IFRS pode trazer maior qualidade para as demonstrações contábeis das empresas brasileiras, maior acurácia na representação da realidade econômicofinanceira, além de proporcionar maior tempestividade e relevância. Portanto, espera-se que os usuários da contabilidade sejam beneficiados com relatórios contábeis mais informativos, o que pode auxiliá-los em suas decisões quanto à alocação de recursos no mercado de capitais e, indiretamente, contribuir para reduzir o custo de capital das empresas listadas em bolsa. Porém, não é sabido em que grau tais benefícios podem ocorrer considerando que a convergência brasileira ocorreu em duas etapas, além dos aspectos institucionais que podem influenciar a qualidade das demonstrações contábeis. Na verdade, estas características representam uma motivação para investigar os efeitos econômicos das IFRS no Brasil.

A motivação desta tese apoia-se na literatura, que aponta alguns benefícios econômicos e financeiros associados à adoção das normas internacionais de contabilidade, como redução com os gastos de conversão de demonstrações contábeis, maior comparabilidade, aumento da transparência dado o maior nível de divulgação de informações, aumento do conteúdo informacional dado a maior relevância da informação contábil (MEULEN; GAEREMYNCK; WILLEKENS, 2007; CAPKUN et al 2008; GJERDE; KNIVSFLA; SAETTEM, 2008; PRATHER-KINSEY; JERMAKOWICZ; VONGPHANITH, 2008; HORTON; SERAFEIM, 2009; ARMSTRONG et al 2010; DEVALLE; ONALI; MAGARINI, 2010; LIMA, 2011), redução do custo de capital (DASKE et al 2008; LI, 2010; LEE; WALKER; CHRISTENSEN, 2010) e aumento da liquidez das ações, oportunidades de investimento proporcionando retornos superiores, uniformização de regras para atender questões contratuais a partir das demonstrações contábeis, ou seja, redução dos custos de transação e da assimetria informacional, contribuindo para uma alocação de recursos no mercado de maneira mais 
eficiente. Grande parte destes benefícios é verificável empiricamente, e muitas pesquisas já foram implementadas em nível nacional e internacional.

\subsection{Problema de Pesquisa}

A adoção das normas internacionais traz como expectativa uma melhora no conteúdo

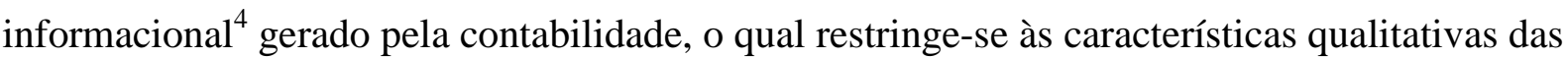
demonstrações contábeis presentes no Pronunciamento Conceitual Básico (R1) ou simplesmente Estrutura Conceitual, tais como: relevância, materialidade, tempestividade, comparabilidade etc. O atual presidente do IASB, Hans Hoogervorst (IFRS, 2011), afirmou que a adoção das IFRS proporciona um aumento na transparência das demonstrações contábeis, ou seja, uma redução no nível de assimetria de informação entre empresa e mercado. Este aspecto, se comprovado, contribui para reduzir o custo de obtenção de informação, que, por sua vez, reflete-se no custo de capital destas empresas, conforme declaração de David Tweedie, ex-presidente do IASB (TWEEDIE, 2006).

Encontram-se na literatura vários trabalhos (quadro 1, página 74) que identificaram benefícios advindos da adoção obrigatória das IFRS, tais como Barth, Landsman e Lang (2008), corroborando as declarações dos defensores das IFRS. Todavia, alguns autores questionam se o padrão contábil internacional é capaz de satisfazer às necessidades informacionais de países tão diferentes em termos de características institucionais (BALL; KOTHARI; ROBIN, 2000; BALL, 2006; HOLTHAUSEN, 2009; WALKER, 2010). Na mesma linha, Soderstrom e Sun (2007) afirmam que o desenvolvimento no ambiente informacional proporcionado pelas IFRS deve ser investigado a partir de diversos incentivos que podem influenciar a divulgação das demonstrações contábeis. Os incentivos compreendem o nível de proteção aos investidores, tributos, estrutura de propriedade, política, estrutura de capital e desenvolvimento do mercado de capitais. As pesquisas de Daske et al (2008), Ball, Robin e Wu (2003) e Christensen, Lee e Walker (2008) são consistentes com a visão de que a implementação das IFRS é heterogênea entre os países, sendo que os incentivos à divulgação dependem de vários fatores, entre eles, o ambiente institucional.

\footnotetext{
${ }^{4} \mathrm{O}$ conteúdo informacional da contabilidade, a qualidade da informação contábil, a qualidade do lucro ou earnings quality podem ser considerados sinônimos, pois estes termos voltam-se, em essência, para a avaliação da utilidade gerada pela contabilidade.
} 
Após confrontar visões favoráveis e desfavoráveis à adoção das IFRS, este trabalho tem o objetivo de investigar se houve um aumento no conteúdo informacional das demonstrações contábeis observado pelas propriedades que definem a qualidade da informação contábil. Ademais, investiga-se o efeito da mudança dos Generally Accepted Accounting Principles (GAAP) sobre o custo de capital próprio. Para observar conteúdo informacional, utiliza-se uma abordagem baseada em Barth et al (2006), na qual algumas dimensões da qualidade da informação contábil são observadas, tais como: gerenciamento de resultados, conservadorismo condicional, relevância e tempestividade. A vantagem de utilizar tal abordagem advém da análise de algumas dimensões da qualidade da informação contábil, sendo que a efetiva utilidade da contabilidade pode ser confirmada ao encontrar resultados coerentes para as dimensões.

A partir deste contexto a questão de pesquisa desta tese é:

\section{Qual o efeito da adoção completa das IFRS na qualidade das demonstrações contábeis e no custo de capital próprio das empresas brasileiras de capital aberto?}

\subsection{Tese}

A proposta de pesquisa partiu da tese de que houve aumento no conteúdo informacional observado pelas propriedades da qualidade da informação contábil (dada pelas dimensões gerenciamento de resultados, conservadorismo condicional, relevância e oportunidade) após adoção completa das normas internacionais de contabilidade e, consequentemente, redução do custo de capital próprio.

\subsection{Desenvolvimento das Hipóteses de Pesquisa}

O desenvolvimento das hipóteses pode tomar como ponto de partida o trabalho de Barth, Landsman e Lang (2008), que observou uma redução no nível de gerenciamento de resultados, um reconhecimento de perdas mais oportuno e, finalmente, maior relevância da informação contábil após adoção das IFRS, ou seja, um aumento na qualidade das demonstrações contábeis. Porém, algumas ressalvas devem ser feitas, visto que, diversos autores (SODERSTROM; SUN, 2007; HOLTHAUSEN, 2009; WALKER, 2010) reconhecem que a implementação das IFRS é influenciada por aspectos legais e institucionais dos países. 
Neste contexto, Armstrong et al (2010) comentam que os investidores podem reagir negativamente a eventos ligados à adoção das IFRS, se eles considerarem que tais normas não refletem adequadamente as diferenças entre os países. Além disso, os investidores poderiam acreditar que a heterogeneidade na aplicação e fiscalização entre os países permitiria um aumento no poder discricionário dos gestores.

Além de Armstrong et al (2010), encontram-se na literatura algumas pesquisas que preveem variações nas práticas de gerenciamento, as quais devem ser consideradas para definir a proposição de gerenciamento de resultado (GR). Por exemplo, Ball (2006) defende que a maior utilização do valor justo pelas IFRS pode contribuir para aumentar a volatilidade das demonstrações contábeis, pois em regimes de baixa qualidade de divulgação os administradores estão dispostos a suavizar os resultados ${ }^{5}$ para alcançar uma variedade de objetivos. Portanto, de acordo com esta linha há uma possibilidade de aumentar as práticas de gerenciamento de resultados. Além disso, Burgstahler, Hail e Leuz (2006) fornecem evidências empíricas de que o nível de gerenciamento de resultados é maior em países de baixo poder de enforcement.

No entanto, é esperado um período de adaptação para as empresas que adotam as novas normas internacionais de contabilidade, o qual está sujeito a transações não contabilizadas adequadamente de acordo com as IFRS, e que podem ser questionadas pelos stakeholders e pela própria CVM. Torres (2011) descreve dois casos de tratamento contábil equivocado. No primeiro, a empresa usa a regra fiscal para explicar as perdas estimadas para créditos de liquidação duvidosa, sendo que não foi analisado verdadeiramente o risco de inadimplência. O segundo caso diz respeito à contabilização de transações entre partes relacionadas por preço que não seja o de mercado. Além disso, há divergência no tratamento contábil de algumas transações ou eventos econômicos, tais como o registro de pagamento de outorga de contratos de concessão, mensuração dos empreendimentos imobiliários pelas administradoras de shopping centers, taxas de depreciação de ativo imobilizado e método para mensuração de ativos biológicos. Segundo Torres (2011), a Energisa - empresa pertencente ao setor de energia elétrica - divulgou em seu balanço instrumentos híbridos de dívida e capital no patrimônio líquido, contrariando a recomendação da CVM de contabilizar no passivo.

\footnotetext{
${ }^{5}$ Resultado equivale ao resultado contábil ou resultado do período, abrangendo tanto casos de lucro quanto de prejuízo.
} 
Diante disto, representantes dos reguladores acreditam que as práticas contábeis devem convergir com o tempo, sendo que, os stakeholders, principalmente, analistas, fundos de investimento e investidores exercerão papel importante em fiscalizar e acompanhar a divulgação das empresas, identificando práticas contábeis que não refletem a substância econômica da transação. Assim, apesar de dificuldades na adoção das IFRS, acredita-se que o início da convergência corresponde a um período educativo, sendo que uma análise do agregado pode revelar uma redução no nível de gerenciamento de resultados como observado por Barth, Landsman e Lang (2008).

Um aspecto favorável à redução do GR baseia-se na relação entre o nível de precisão da norma contábil, rules-based versus principles-based, e a divulgação agressiva $^{6}$ das demonstrações contábeis. Alguns autores (NELSON, et al 2002; MAINES, et al 2003; AGOGLIA; DOUPNIK; TSAKUMIS, 2011) observaram que quanto maior a precisão do sistema contábil (rules-based) maior será a ocorrência de divulgação agressiva. Assim, considerando que a transição de GAAP no Brasil parte de um sistema rules-based para um principles-based, as práticas voltadas para a divulgação agressiva podem ser limitadas ${ }^{7}$. Ademais, a habilidade da administração em gerenciar os resultados pode diminuir quando da emissão de uma nova norma (WATTS; ZIMMERMAN, 1986; BEYER et al, 2010).

Apesar de encontrar aspectos favoráveis ao aumento do GR, acredita-se que o conjunto das normas internacionais pode resultar em demonstrações contábeis mais úteis para os usuários, livre de qualquer tipo de manipulação que resulte em divulgação agressiva. Neste sentido, as demonstrações estariam mais próximas do que se define como representação fidedigna: completa, neutra e livre de erro (PRONUNCIAMENTO CONCEITUAL BÁSICO (R1)). Portanto, a hipótese de gerenciamento de resultados pode ser definida:

\section{$H_{1}$ : a adoção completa das IFRS proporciona uma redução no nível de gerenciamento de resultados das demonstrações contábeis das empresas brasileiras de capital aberto.}

\footnotetext{
${ }^{6}$ A divulgação agressiva tem o propósito de divulgar uma informação que não reflete a realidade financeira da empresa (KOTHARI, 2001).

${ }^{7}$ No Brasil, a divulgação agressiva dada pela manipulação de números contábeis foi constatada por Martinez (2008).
} 
Os conceitos de prudência e conservadorismo são similares ${ }^{8}$ e comumente discutidos no contexto da qualidade informacional da contabilidade. Há duas questões importantes a serem ponderadas: i) se o conceito de prudência é um elemento desejável nas demonstrações contábeis, visto que o mesmo foi excluído da estrutura conceitual das IFRS; ii) quais são as linhas que defendem uma variação no conservadorismo em vista da adoção completa das IFRS.

Em busca de uma estrutura conceitual sólida, a prudência tem sido discutida pelo IASB, resultando em sua substituição pela neutralidade. A supressão do conceito de prudência da estrutura conceitual provocou algumas críticas, voltadas para a possibilidade de menor exercício de cautela nos registros contábeis. Recentemente, o presidente do IABS, Hans Hoogervorst, comentou sobre as implicações e motivações de tal alteração. O presidente declarou que não há nenhum problema com o conceito de prudência, mas o uso excessivo do conservadorismo pode distorcer os relatórios contábeis com o objetivo de enganar os investidores. Além disso, a ausência de prudência na estrutura conceitual do United States Generally Accepted Accounting Principles (USGAAP) motivou a eliminação de prudência da estrutura conceitual do IFRS, em consonância ao processo de convergência entre USGAAP e IFRS. Embora a alteração seja justificada, o presidente reconhece que o conceito de prudência está enraizado em várias normas, tal como o teste de impairment (IFRS, 2012). Na verdade, o conceito de prudência está vivo no conjunto das IFRS, embora não esteja explícito na estrutura conceitual. Neste contexto, justifica-se o estudo do conservadorismo no âmbito da qualidade das demonstrações contábeis.

A segunda questão diz respeito às linhas que defendem uma variação no conservadorismo em vista da adoção completa das IFRS. Por exemplo, Barth (2008) questiona a presença do conservadorismo nas demonstrações contábeis, pois não é uma característica qualitativa da estrutura conceitual do IASB. A autora reforça que o conservadorismo promove a subavaliação deliberada de receitas e ativos, e também a superavaliação de despesas e passivos, resultando em informação contábil tendenciosa. Além disso, a abordagem value-

\footnotetext{
${ }^{8}$ Os eventos registrados pela contabilidade são associados a diferentes níveis de incerteza. A prudência consiste no emprego de cautela diante de eventos incertos, no sentido de que ativos ou receitas não sejam superestimados e que passivos ou despesas não sejam subestimados (PRONUNCIAMENTO CONCEITUAL BÁSICO). Conservadorismo pode ser definido como reconhecimento assimétrico entre despesas e passivos e ativos e receitas. Deve-se escolher sempre o cenário com maiores despesas e passivos, e menores receitas e ativos (LOPES; MARTINS, 2005).
} 
relevance implica em informação neutra. De acordo com essa linha, a aplicação das IFRS não deve resultar em demonstrações contábeis conservadoras. Hendriksen e Van Breda (1999) partilham da mesma visão, e acrescentam que o conservadorismo pode levar a uma distorção completa dos relatórios contábeis.

No entanto, um trabalho publicado pela American Accounting Association's Financial Accounting Standards Committee (AAA FASC, 2010) defende o uso do conservadorismo desde que não haja exagero, ou o exercício da discricionariedade por meio de práticas de gerenciamento de resultado. Na mesma linha, Kothari, Ramanna e Skinner (2010) desenvolveram uma teoria econômica do GAAP, que prevê um tratamento assimétrico entre ganhos e perdas, enquanto Lambert (2010) considera o conservadorismo como um elemento crítico da contabilidade. Por fim, Watts (2003) acredita que a aplicação do conservadorismo ocorre diante de incentivos para os gestores introduzirem viés nas estimativas contábeis, mas a sua eliminação implica no descarte de benefícios voltados para o bem estar de investidores e credores, resultando em problemas nas estimativas divulgadas. Consequentemente, o autor defende a aplicação de um conservadorismo mais verificável, que impede manipulações dos números contábeis, como aconteceu no caso da Enron, no qual, entre vários mecanismos para iludir o mercado, os gestores da empresa aplicaram marcação a mercado sem assegurar a devida verificabilidade para as estimativas contábeis. Em resumo, estes autores reconhecem que o conservadorismo é uma característica fundamental na contabilidade, embora façam algumas ressalvas quanto ao seu uso.

Apesar das linhas divergentes acerca do papel do conservadorismo na contabilidade, a literatura de earnings quality ${ }^{9}$ considera que a existência do conservadorismo reflete um aumento do conteúdo informacional das demonstrações contábeis, assim, como constatado por Barth, Landsman e Lang (2008). Adicionalmente, ao considerar o conservadorismo como um atributo desejável das demonstrações contábeis, espera-se que o conjunto das IFRS permita o reconhecimento de transações anteriormente não contabilizadas pelas empresas, considerando a existência de normas específicas que, indiretamente, invocam o uso do conservadorismo. Portanto, pode-se definir a hipótese de conservadorismo:

\footnotetext{
${ }^{9}$ Earnings quality é uma linha de pesquisa que investiga a qualidade da informação contábil, ou simplemente, a qualidade do resultado contábil. O resultado de alta qualidade fornece mais informações sobre as características de desempenho financeiro de uma empresa, as quais são relevantes para a tomada de decisão (DECHOW; GE; SCHRAND, 2010).
} 


\section{$\mathrm{H}_{2}$ : a adoção completa das IFRS proporciona um aumento no conservadorismo condicional das demonstrações contábeis das empresas brasileiras de capital aberto.}

Após apresentar as proposições para gerenciamento e conservadorismo, pode-se analisar as expectativas quanto à relevância da informação contábil, abordada na literatura internacional por meio dos estudos de value-relevance. A relevância é uma das características qualitativas da informação contábil presente na estrutura conceitual, sendo definida como aquela capaz de fazer diferença nas decisões que possam ser tomadas pelos usuários (PRONUNCIAMENTO CONCEITUAL BÁSICO (R1)). Encontra-se na literatura nacional (LIMA, 2010) e internacional (BARTH; LANDSMAN; LANG, 2008) trabalhos que investigaram a relevância da informação contábil após adoção obrigatória das IFRS ${ }^{10}$, sendo que os achados revelam um aumento na relevância da informação contábil. Considerando que os métodos de avaliação da relevância da informação contábil residem em testes de associação entre preço ou retorno das ações e números contábeis, então, espera-se que, após a adoção completa das IFRS, esta associação tenha aumentado significativamente, revelando maior utilidade da informação em IFRS.

A justificativa para esta maior associação fundamenta-se, segundo Barth, Landsman e Lang (2008), na preocupação do IASB em desenvolver normas contábeis que limitem as ações oportunistas dos gestores. Sendo assim, o investidor pode receber informação contábil de elevada qualidade, portanto, mais relevante para suas decisões de investimento. Portanto, de acordo com esta linha, espera-se que a mudança de GAAP, BRGAAP para IFRS, implique em aumento da relevância da informação contábil.

No entanto, diversos fatores podem influenciar a qualidade da informação contábil divulgada, tais como, sistema político e legal, desenvolvimento de mercado de capitais, estrutura de capital, estrutura de propriedade, tributos (SODERSTROM; SUN, 2007; HOLTHAUSEN, 2009). Complementarmente, Ball (2006) afirma que, na ausência de mecanismos de enforcement adequados, é improvável que a convergência de fato ocorra. Neste sentido, podese não observar um aumento na relevância da informação contábil. Apesar desta ressalva quanto à observação dos benefícios associados às normas internacionais de contabilidade,

\footnotetext{
${ }^{10} \mathrm{O}$ quadro 1 apresenta um resumo de vários trabalhos nacionais e internacionais que investigaram as consequências econômicas da adoção das IFRS.
} 
acredita-se que os indícios já observados por Lima (2010) na adoção parcial são favoráveis à expectativa de aumento da relevância no período da adoção completa, resultando na seguinte hipótese:

\section{H3: a adoção completa das IFRS proporciona um aumento na relevância das demonstrações contábeis das empresas brasileiras de capital aberto.}

A última característica qualitativa da estrutura conceitual investigada nesta tese corresponde à tempestividade, que significa ter informação disponível para tomadores de decisão a tempo de poder influenciá-los em suas decisões (PRONUNCIAMENTO CONCEITUAL BÁSICO (R1)).

Ao conjecturar um aumento no conservadorismo condicional (hipótese de pesquisa $\mathrm{H}_{2}$ ), e assumir maior reconhecimento assimétrico entre ganhos e perdas, é esperado um aumento na tempestividade do resultado contábil. Os elementos de tempestividade e conservadorismo estão correlacionados, pois o exercício do primeiro implica na capacidade do resultado em refletir boas e más notícias, enquanto o segundo está associado à antecipação de perdas futuras.

No cenário brasileiro, há indícios de baixa tempestividade do resultado contábil no período 1996-1999 (LOPES, 2001). No entanto, Lima (2010) investigou o período da adoção parcial (2008-2009) e observou um resultado contábil tempestivo, demonstrando a evolução da qualidade da informação contábil no mercado brasileiro. Neste sentido, se as demonstrações contábeis full IFRS representam um conjunto de práticas contábeis de elevada qualidade, e o mercado de capitais compreende a informação contábil divulgada, espera-se um conteúdo informacional superior em função do reconhecimento de eventos econômicos não considerados anteriormente, como pagamento baseado em ações, instrumentos financeiros derivativos etc. Além disso, tem-se o reconhecimento mais oportuno de ganhos e perdas econômicas devido à utilização do valor justo (CHALMERS; CLINCH; GODFREY, 2011).

Na mesma linha, Ball (2006) defende que a mensuração a valor justo implica em informação contábil mais tempestiva, tais como, o registro de ganhos e perdas de títulos, derivativos, além de reconhecer prontamente perdas por meio do teste de impairment aplicado aos ativos de longo prazo. Neste sentido, as IFRS podem gerar números contábeis mais informativos, 
porém com maior volatilidade, prejudicando a realização de previsões. Em resumo, todos estes aspectos contribuem para um aumento na tempestividade dos números contábeis, permitindo definir a seguinte hipótese:

\section{$H_{4}$ : a adoção completa das IFRS proporciona um aumento na tempestividade das demonstrações contábeis das empresas brasileiras de capital aberto.}

Após o desenvolvimento das hipóteses de pesquisa no contexto da adoção completa das IFRS, pode-se resumi-las na ilustração 1:

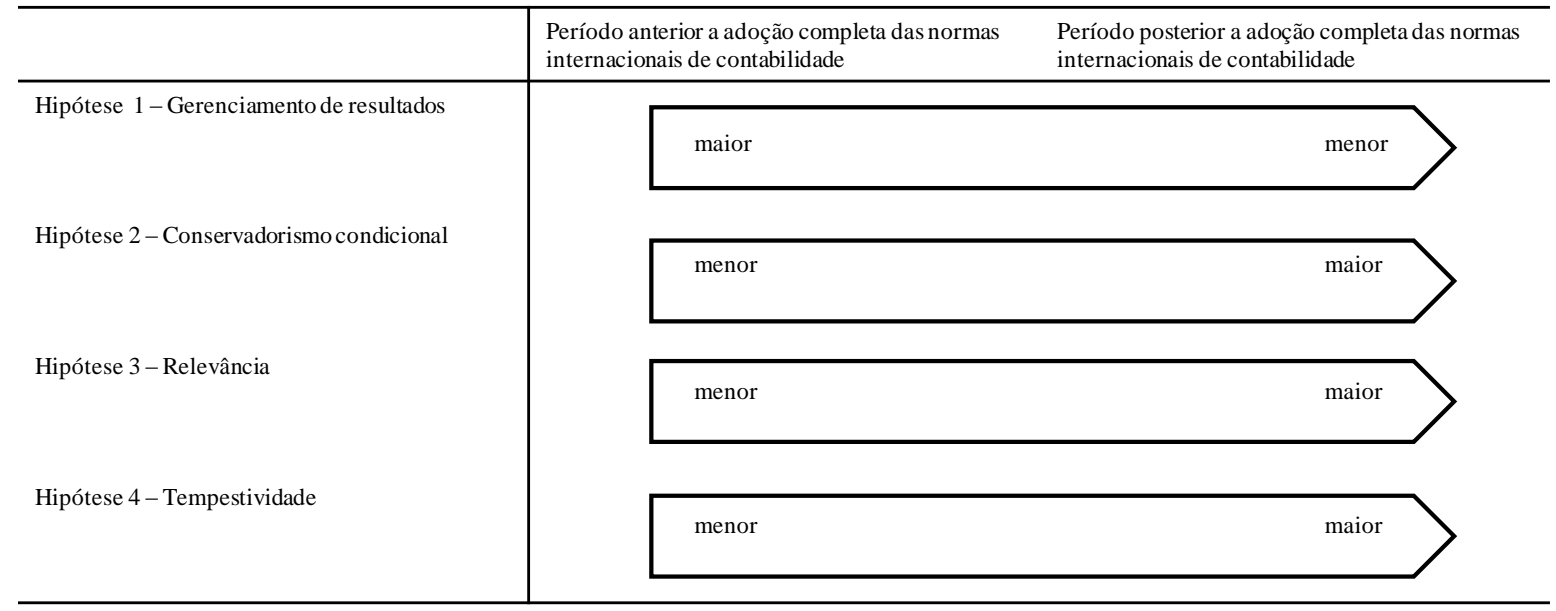

Ilustração 1 - Esquema das hipóteses de pesquisa sobre as dimensões da qualidade da informação contábil.

A análise das dimensões da qualidade da informação contábil pode resultar em evidências empíricas convergentes, isto é, os achados podem indicar um aumento no conservadorismo, relevância e tempestividade da informação full IFRS, além de redução no gerenciamento de resultado. Assim, têm-se demonstrações contábeis de qualidade superior após adoção completa das IFRS, culminando na seguinte hipótese de pesquisa:

\section{H5: a adoção completa das IFRS proporciona um aumento na qualidade das demonstrações contábeis das empresas brasileiras de capital aberto.}

Assumindo um aumento na qualidade da informação contábil, é esperada uma redução no custo de capital próprio, em função da menor assimetria informacional entre empresas e investidores. Uma justificativa para tal relação baseia-se em um cenário de baixo conteúdo 
informacional, dificultando as atividades de avaliação e monitoramento, no qual os investidores serão relutantes em investir seus recursos nas empresas (BURGSTAHLER; HAIL; LEUZ, 2006). Neste contexto, os países que adotam as IFRS aplicam normas contábeis que produzem demonstrações contábeis de elevada qualidade, aumentando a transparência e facilitando a comparabilidade. Consequentemente, os custos de processamento dos investidores internacionais são reduzidos (HAIL; LEUZ, 2009; LEE; WALKER; CHRISTENSEN, 2010). Neste cenário, é plausível conjecturar uma redução no custo de capital próprio das empresas.

No entanto, a qualidade da informação contábil é influenciada por aspectos institucionais, como a baixa proteção legal concedida aos investidores em países de origem code law, tal como o Brasil (LA PORTA; LOPES-DE-SILANES; SHLEIFER, 1999). De acordo com esta linha, a disposição dos investidores em investir pode diminuir, levando a aumentos no custo de capital próprio das empresas. Por exemplo, a evidência de práticas de gerenciamento de resultado em função de ambiente informacional fraco pode resultar em maior custo de capital próprio, tal como apontado por Dechow e Dichev (2002) e Francis et al (2005).

Por outro lado, Gao (2010) argumenta que a maior qualidade da divulgação não está associada necessariamente à redução no custo de capital das empresas. O autor explica que este efeito deve-se ao ambiente complexo no qual a empresa está inserida, pois as decisões de investimento são influenciadas pela divulgação das empresas, e os investidores atuais podem vender suas participações na empresa após receberem informação que altera suas expectativas, diminuindo a eficácia do custo de capital como medida do bem estar dos investidores.

Apesar de visões contrárias a respeito da relação entre ambiente informacional e custo de capital próprio, acredita-se que as demonstrações contábeis full IFRS podem contribuir para reduzir a assimetria de informação entre mercado e empresas, resultando em maior eficiência na alocação de recursos. Assim, a hipótese referente ao custo de capital próprio pode ser definida:

\section{$H_{6}$ : a adoção completa das IFRS proporciona uma redução no custo de capital próprio das empresas brasileiras de capital aberto.}


Ilustrativamente tem-se:

\begin{tabular}{l|cl}
\hline & Período anterior à adoção completa da IFRS & $\begin{array}{l}\text { Período correspondente à adoção completa das } \\
\text { IFRS }\end{array}$ \\
\hline Hipótese 6 - Custo de capital próprio & maior \\
\hline
\end{tabular}

Ilustração 2 - esquema de hipótese de pesquisa sobre custo de capital.

\subsection{Objetivos}

\subsubsection{Objetivo Geral}

O objetivo geral deste estudo é investigar o impacto da adoção completa das IFRS na qualidade das demonstrações contábeis e no custo de capital próprio das empresas brasileiras de capital aberto.

\subsubsection{Objetivos Específicos}

Os objetivos específicos consideram a multidimensionalidade da qualidade da informação contábil, justificando o uso de algumas medidas vinculadas à percepção dos investidores, e outras que refletem as diferenças entre caixa e competência (FRANCIS; OLSSON; SCHIPPER, 2008; DECHOW; GE; SCHRAND, 2010). Diante disto, justifica-se o método denominado portfolio approach, que analisa alguns aspectos da qualidade da informação contábil, sendo usado em diversos trabalhos, tais como, Barth et al (2006), Barth, Landsman e Lang (2008), Lopes e Walker (2008), Christensen, Lee e Walker (2008), Paananen e Lin (2009). Nesta tese, os atributos pesquisados da qualidade da informação contábil perfazem os seguintes objetivos específicos: i) investigar o gerenciamento de resultado após adoção completa das IFRS; ii) analisar o conservadorismo condicional após adoção completa das IFRS; iii) averiguar a relevância após adoção completa das IFRS; e iv) avaliar a tempestividade após adoção completa das IFRS.

Além disso, faz parte do conjunto de objetivos específicos avaliar o comportamento do custo de capital próprio das empresas brasileiras após adoção completa das IFRS. 
Adicionalmente, pretende-se investigar o papel da governança corporativa na qualidade da informação contábil. O modelo de governança corporativa brasileiro, dado pela baixa proteção aos investidores e elevada concentração de propriedade, pode trazer algumas dificuldades de financiamento para as empresas que possuem oportunidades de crescimento. Diante disso, algumas empresas buscam recursos por meio da emissão de American Depositary Receipt - ADR, atendendo diversas exigências impostas pela Securities and Exchange Commission (SEC) e, consequentemente, auferindo maior credibilidade aos seus relatórios contábeis. Embora o risco de litígio implique em relatórios contábeis mais conservadores, o baixo enforcement aliado a diversos incentivos para gerenciar os números contábeis resultam em baixo conteúdo informacional das demonstrações contábeis. Estes incentivos juntamente com o exercício da função contratual e informacional pela contabilidade acabam determinando as suas propriedades, em detrimento das próprias normas contábeis (LOPES, 2008). Neste contexto, pode-se concluir que o ambiente legal e institucional tem influência sobre a qualidade da informação contábil, implicando em incentivos para as empresas buscarem mecanismos contra os problemas informacionais e de agência e, assim, facilitar a obtenção de recursos no mercado de capitais. Para isso, pode-se desenvolver estruturas de governança corporativa e controle voltados para evitar a expropriação de riqueza (LOPES; MARTINS, 2005), influenciando o nível de transparência e os direitos concedidos aos acionistas não controladores.

Na literatura internacional, há evidência empírica sobre a influência de práticas de governança corporativa na qualidade da informação contábil (BALL; KOTHARI; ROBIN, 2000). Já no cenário nacional, Lopes e Walker (2008) e Gabriel (2011) encontraram indícios de que a existência de práticas de governança corporativa pode aumentar a qualidade da informação contábil.

Por sua vez, Goh e Li (2011) argumentam que os administradores possuem incentivos para tomar decisões voltadas para a divulgação de demonstrações contábeis agressivas, ou seja, não correspondentes à realidade econômico-financeira da empresa. As práticas de governança corporativa podem coibir tais decisões, justificando a sua consideração nesta tese. Logo, espera-se uma correlação negativa entre práticas de governança corporativa e ações de gerenciamento de resultado. 
Neste sentido, constitui-se como objetivo específico desta tese aplicar o índice de governança corporativa, denominado Brazilian Corporate Governance Index (BCGI), baseado em Lopes e Walker (2008), com o propósito de investigar o efeito das práticas de governança corporativa na qualidade da informação contábil das empresas brasileiras de capital aberto.

\subsection{Justificativa e Contribuição}

Os defensores das IFRS justificam a adoção das normas internacionais em função de diversos benefícios que a padronização pode gerar para as empresas e para a economia, tais como aumento da liquidez, maiores oportunidades de investimento, atendimento de questões contratuais, redução dos custos de transação e da assimetria informacional. Essas crenças estimularam diversas pesquisas científicas a nível nacional e internacional, que passaram a investigar a existência de tais benefícios. No Brasil, dois trabalhos já investigaram o conteúdo informacional (LIMA, 2010) e o custo de capital próprio (LIMA, 2011) no contexto das IFRS, mas ambos trataram do período da adoção parcial (2008 -2009), no qual as empresas adotaram alguns CPCs. Esta tese justifica-se pelo propósito de analisar o período da adoção completa (2010-2011), que compreende quase integralmente ${ }^{11}$ às normas internacionais de contabilidade. Ademais, este trabalho observa conteúdo informacional e custo de capital próprio de maneira conjunta. Os resultados reportados aqui, juntamente com as evidências empíricas de outros trabalhos, podem ser úteis na discussão sobre o futuro das demonstrações contábeis, considerando as discussões organizadas pelo IASB, que voltam-se para os desafios das normas contábeis internacionais em abranger as divergências dos países ${ }^{12}$.

Além disso, sabe-se que a divulgação das demonstrações contábeis não é determinada apenas pela qualidade das normas contábeis em vigor no país (BALL; ROBIN; WU, 2003) ${ }^{13}$, e ao

\footnotetext{
11 A norma IAS 29, Financial Reporting in Hyperinflationary Economies, não foi adotada no processo de convergência brasileiro, impedindo afirmar que, as empresas brasileiras adotam literalmente todas as normas internacionais nas demonstrações individuais. No entanto, este e outros exemplos não impedem de afirmar que, as Demonstrações Contábeis após aplicação dos CPCs estão de acordo com as IFRS.

12 Uma das discussões pode ser vista em <http://www.ifrs.org/Features/Pages/Panel-dicsussion-future-offinancial-reporting-video.aspx>. Acesso em 16 de fevereiro de 2013.

13 Segundo Ball, Robin e Wu (2003), a divulgação das demonstrações contábeis é influenciada por vários incentivos, os quais, por sua vez, dependem da interação de forças políticas e de mercado no ambiente jurídico em análise. As forças de mercado incluem a demanda por relatórios financeiros de alta qualidade, enquanto que, as forças políticas abrangem o envolvimento do governo em determinar e fiscalizar as normas contábeis, além de haver incentivos para reduzir a variabilidade do lucro, com o propósito de não divulgar grandes lucros ou prejuízos. A partir deste cenário, os autores estudaram a qualidade das demonstrações contábeis nos países China, Malásia, Singapura e Tailândia, os quais apresentam padrões contábeis de alta qualidade, mas possuem uma estrutura institucional sem incentivos para divulgar relatórios de alta qualidade. Os autores utilizaram como
} 
restringir o estudo a um ambiente jurídico, pode-se aumentar o poder dos testes ao controlar por fatores que variam internacionalmente e influenciam a qualidade da informação contábil (HOLTHAUSEN, 2009).

Outra justificativa reside na relação positiva entre qualidade das demonstrações contábeis e eficiência de investimentos. Chen et al (2011, p. 1256) examinaram a relação entre a qualidade da divulgação das demonstrações contábeis ${ }^{14}$ e eficiência de investimentos para uma amostra de empresas em mercados emergentes, entre eles o Brasil. Os achados indicam que a qualidade da divulgação é positivamente associada com eficiência de investimentos, apesar de pesquisas anteriores observarem que a qualidade de divulgação das empresas de capital fechado é baixa em relação às empresas de capital aberto, e menor nos mercados emergentes comparativamente aos mercados desenvolvidos. Na mesma linha, Healy e Whalen (1999) e Dechow e Skinner (2000) defendem uma alocação eficiente de recursos em cenários cujas demonstrações contábeis permitem que usuários tenham maior facilidade de avaliar desempenho. Neste contexto, esta tese pode trazer indícios de redução da informação assimétrica e, consequentemente, de eficiência na alocação de recursos.

Este estudo pode contribuir para a compreensão do comportamento e formação de preços no mercado de ações e da função informacional da contabilidade no atual cenário de convergência para as normas internacionais de contabilidade. Espera-se fornecer evidências empíricas acerca do impacto das demonstrações contábeis elaboradas de acordo com as IFRS no mercado de capitais, que podem corroborar as declarações do IASB a respeito dos benefícios associados com a adoção das normas. Além disso, alguns países ainda discutem as possíveis consequências econômicas proporcionadas pela adoção as IFRS, como os Estados Unidos. Em relatório publicado recentemente por um grupo de trabalho da SEC, denominado Work Plan for the Consideration of Incorporating International Financial Reporting Standards into the Financial Reporting System for U.S. Issuers, foram listados diversos pontos que dificultam a convergência USGAAP para IFRS. Assim, a convergência contábil ainda é um assunto muito discutido por reguladores e usuários da contabilidade. Diante disto,

proxy de qualidade da informação contábil o reconhecimento oportuno de perdas com base em Basu (1997). Os resultados mostram que os países da amostra, de origem common law, possuem números contábeis de qualidade inferior em relação aos países Austrália, Canadá e Estados Unidos.

14 Tradução livre de "financial reporting quality". 
esta tese pode trazer evidências que contribuam para compreender o impacto das IFRS na qualidade das demonstrações contábeis e no custo de capital próprio das empresas.

\subsection{Estrutura do Trabalho}

O trabalho está dividido em 5 seções: i) a primeira apresenta a introdução com contextualização da pesquisa, problema, tese, hipóteses de pesquisa, objetivos e justificativa; ii) a segunda contém a plataforma teórica com as subseções: mercado de capitais e informação contábil, teoria positiva da contabilidade, o processo de convergência no mundo, o processo de convergência no Brasil, informação contábil e aspectos institucionais, conteúdo informacional, gerenciamento de resultado, conservadorismo condicional, relevância da informação contábil, o modelo de Ohlson, governança corporativa no Brasil e sua relação com a qualidade da informação contábil, e consequências econômicas da adoção das IFRS; iii) a terceira expõe os aspectos metodológicos da tese com apresentação dos modelos, variáveis consideradas e expectativas a partir da adoção completa das IFRS; iv) a quarta seção constitui-se na análise dos resultados, contendo a aplicação dos testes e interpretação de acordo com a lógica dos modelos; e v) a última faz as considerações finais e ressalta as principais limitações. 


\section{PLATAFORMA TEÓRICA}

\subsection{Mercado de Capitais e Informação Contábil}

O objetivo desta seção é descrever as principais linhas de pesquisa de contabilidade no âmbito do mercado de capitais.

O trabalho de Kothari (2001) faz uma extensa revisão de estudos que investigam a relação entre mercado de capitais e demonstrações contábeis, além de apresentar uma avaliação crítica de alguns achados. O autor ainda destaca a importância de um guia teórico para a pesquisa empírica nesta linha, após observar que os principais tópicos de interesse dos pesquisadores são: teste de eficiência do mercado a partir de informação contábil, análise fundamentalista e avaliação baseada em números contábeis, e a relevância da informação contábil.

$\mathrm{O}$ autor explica que a análise fundamentalista provém da necessidade de alguns stakeholders em avaliar a empresa. O conteúdo informacional da contabilidade pode ser útil nesta tarefa, considerando a possibilidade de usar as demonstrações contábeis para precificar as ações.

O uso da contabilidade para este propósito está previsto no Pronunciamento Conceitual Básico (R1). O item OB3, ao tratar dos objetivos das demonstrações contábeis, esclarece que as expectativas dos investidores e credores dependem do montante, tempestividade e incerteza dos fluxos de caixa futuros da entidade. Para isso, eles necessitam de informação para auxiliálos na avaliação das perspectivas em termos de fluxos de caixa futuros, as quais podem ser obtidas nas demonstrações contábeis. Portanto, a contabilidade representa um importante elemento na avaliação de empresas, pois pode alterar as expectativas dos usuários em relação à geração de fluxos futuros de caixa.

Outra linha de pesquisa volta-se para testes de eficiência de mercado, com o propósito de investigar as reações do mercado de capitais a partir de eventos contábeis. Estas pesquisas baseiam-se no conceito de mercado eficiente, segundo o qual, o preço das ações reflete as informações disponíveis. Sendo assim, Kothari (2001, p. 110) afirma que “[...] a mudança de um método contábil para outro sem efeito direto no fluxo de caixa [...] não afeta o preço das 
ações em um mercado eficiente”. Para investigar tais questões, os principais métodos de pesquisa são estudo de evento e testes em corte transversal de retorno.

Outro tema presente na revisão de Kothari (2001, p. 112) diz respeito à regulação da divulgação de demonstrações contábeis. As pesquisas deste tema podem auxiliar os reguladores contábeis a verificar se os objetivos das demonstrações contábeis estão sendo atendidos. Os trabalhos buscam respostas para diversas questões, por exemplo:

- As demonstrações contábeis preparadas de acordo com uma nova norma contábil revelam informação para o mercado de capitais?

- Os números contábeis de demonstrações contábeis preparadas de acordo com uma nova norma são mais associados com preço e retorno corrente das ações?

- Quais as consequências econômicas da emissão de um novo padrão de divulgação?

Estas indagações, segundo o Kothari (2001), são de interesse dos reguladores, e ainda, auxiliam o estudo da eficiência do mercado de capitais. Além disso, pode-se trazer evidências sobre uma das questões mais discutidas recentemente no campo da contabilidade: os efeitos da convergência dos sistemas contábeis para um único conjunto de normas contábeis.

Kothari (2001) ainda faz uma revisão histórica de estudos relacionados à contabilidade no mercado de capitais, partindo de trabalhos clássicos como Ball e Brown (1968) e Beaver (1968), os quais representam um importante divisor na pesquisa contábil. Anteriormente a estes trabalhos, a pesquisa era predominantemente normativa com grande enfoque sobre o desenvolvimento de uma teoria contábil. Neste contexto, enquanto representantes da academia e mercado discutiam sobre as "melhores" práticas contábeis ou bases de mensuração, outros, como Ball e Brown (1968) e Beaver (1968), forneciam evidência empírica sobre a utilidade dos números contábeis. A partir destes resultados, surgiram desenvolvimentos em três áreas que representam importantes mudanças: i) a teoria positiva, ii) as hipóteses do mercado eficiente e Capital Asset Pricing Model (CAPM); e iii) o estudo de evento de Fama et al (1969).

A pesquisa positiva, com grande influência de Friedman, trouxe elementos fundamentais para o desenvolvimento do conhecimento contábil em termos metodológicos. Com o desenvolvimento da pesquisa no campo contábil surgiu o interesse de pesquisadores em 
validar suas hipóteses por meio de evidências empíricas, sendo que, muitos usaram a hipótese do mercado eficiente (FAMA, 1965) para avaliar o papel da informação contábil no mercado de ações. Assim, a utilidade da informação contábil pôde ser avaliada a partir do comportamento dos preços das ações em um cenário de mercado eficiente (KOTHARI, 2001).

Alguns ano depois, Watts e Zimmerman publicaram várias obras que constituíram a Teoria Positiva da Contabilidade. A principal contribuição dos autores reside em ligar as práticas contábeis à Teoria de Agência de Jensen e Meckling (1976). A possibilidade de o gestor exercer seu poder discricionário diante de alternativas contábeis fundamenta-se na natureza humana, utilitarista e racional, visto que as pessoas buscam maximizar sua função utilidade, direcionando as escolhas para as suas preferências e objetivos. Essa hipótese está fundamentada no fato de que, as pessoas são menos eficazes no cumprimento de objetivos de terceiros em relação aos seus próprios (JENSEN; MECKLING, 1998). Entendendo a empresa como um nexo de contratos, Watts e Zimmerman (1986), desenvolveram hipóteses para explicar variações no processo contábil das empresas, as quais são fundamentadas por incentivos distintos entre as partes.

A Teoria Positiva da Contabilidade de Watts e Zimmerman (1986) favoreceu o surgimento de várias pesquisas na área de mercado de capitais e contabilidade nas décadas de 80 e 90, as quais são classificadas por Kothari (2001) em 5 linhas de acordo com a tabela 1.

Tabela 1 - Pesquisas na área de mercado de capitais e contabilidade Pesquisas na área de mercado de capitais e contabilidade

i) Methodological capital markets research

- Pesquisas de coeficientes-resposta do resultado contábil

- Propriedades de séries temporais, e previsões de analistas e administradores

- Questões metodológicas ao fazer inferências estatísticas

- Modelos para analisar discricionariedade a partir de accruals

ii) Avaliação de medidas contábeis de desempenho

iii) Avaliação e análise fundamentalista

iv) Teste de eficiência de mercado

v) Value-relevance da divulgação

FONTE: KOTHARI; 2001, p. 123.

Considerando a diversidade de pesquisas no primeiro grupo, methodological capital markets research, Kothari (2001, p. 123) o dividiu em quatro subgrupos, conforme tabela 1.

Segundo o autor, a motivação para o $1^{\circ}$ subgrupo, pesquisas de coeficientes-resposta do resultado contábil, deve-se a possibilidade de utilização do resultado contábil nos modelos de 
avaliação e análise fundamentalista. No entanto, esta abordagem apresenta três fraquezas: i) as pesquisas sobre persistência e sua relação com os coeficientes-resposta do resultado tendem a apresentar, naturalmente, um enfoque estatístico, deixando de explorar, em alguns casos, os determinantes econômicos; ii) a literatura apresenta evidências sobre a relação entre coeficientes-resposta do resultado e persistência para a mesma amostra e período, porém a confiança dos resultados pode ser questionada quando não há testes de previsão ou predictive test; iii) a terceira, exposta por Watts (1992), diz respeito ao problema de variáveis omitidas correlacionadas, que surge pela falha em controlar diferenças temporais no fluxo de caixa efeitos do resultado sobre fluxo de caixa corrente e futuro - e métodos contábeis.

A respeito do $2^{\circ}$ subgrupo da tabela 1 , propriedades de séries temporais e previsões de analistas e administradores, Kothari (2001) apresenta algumas motivações para as pesquisas desta área. Em primeiro lugar, todos os modelos de avaliação usam, direta ou indiretamente, previsões do resultado contábil, inclusive o residual income valuation model (RIV) (OHLSON, 1995). A segunda motivação decorre da necessidade em separar os componentes surpresa e antecipado do resultado líquido. Estes componentes podem ser diferenciados da seguinte maneira: enquanto o primeiro pode trazer nova informação para o mercado, o segundo já foi incorporado pelo mercado em períodos anteriores. Portanto, de acordo com o autor, o ideal seria separar os dois componentes, com o propósito de avaliar a relação entre retorno e resultado, este composto apenas pelo seu efeito surpresa. A terceira motivação é fruto de questionamentos em relação à hipótese de mercado eficiente. Kothari (2001) afirma que a pesquisa contábil baseada em mercado de capitais tem fornecido evidências incoerentes com a hipótese de mercado eficiente.

O terceiro subgrupo envolve questões metodológicas originadas pelas inferências estatísticas, visto que alguns problemas econométricos são exclusivos da pesquisa contábil em mercado de capitais. Sendo assim, o conhecimento e tratamento destes itens são extremamente importantes para o avanço das pesquisas, pois as mesmas sustentam inferências a partir da análise estatística. As principais são: i) viés nos testes estatísticos em função de problemas de correlação (CHRISTIE, 1987); ii) modelos de regressão baseados em retorno e preço das ações (KOTHARI; ZIMMERMAN, 1995); e iii) análise do conteúdo informacional de modelos alternativos (DECHOW, 1994). 
O quarto subgrupo da tabela 1 denominado "Modelos para analisar discricionariedade a partir de accruals" ${ }^{\prime 15}$, compreende estudos voltados para identificar prática de gerenciamento de resultado a partir de incentivos da administração. Este assunto é discutido com mais detalhes na seção 2.8 .

O segundo grupo da tabela 1 "avaliação de medidas contábeis de desempenho", trata de estudos que analisam a relação entre retorno das ações e medidas diferentes de resultado. Kothari (2001, p. 167) explica que "[...] a maior motivação para as pesquisas comparando medidas de desempenho alternativas é perceber deficiências em algumas medidas de desempenho"16. Neste contexto, os pesquisadores usam o termo earnings quality ou qualidade do resultado para investigar se a informação contida no resultado é útil para os investidores.

O terceiro grupo "avaliação e análise fundamentalista" tem como principal motivação a possibilidade de identificar ações não precificadas adequadamente para fins de investimentos. A análise fundamentalista permite entender os determinantes do valor, facilitando as decisões de investimento e avaliações de títulos não negociados publicamente. A ideia principal é acompanhar e explicar a diferença entre o valor intrínseco e de mercado da empresa.

Em sua ampla revisão, Kothari (2001) cita os principais modelos de avaliação usados na análise fundamentalista: modelo baseado em dividendos ou alguma variação, o RIV e um modelo baseado no balanço patrimonial (BARTH; BEAVER; LANDSMAN, 1992). O autor também comenta sobre a facilidade de aplicação do modelo de Feltham e Ohlson (1995), além de discutir suas propriedades. O modelo de Ohlson e suas propriedades são apresentados na seção 2.12 desta tese.

\subsection{Teoria Positiva da Contabilidade}

O objetivo desta seção é descrever a origem e os principais incentivos para a pesquisa positivista na contabilidade.

\footnotetext{
${ }^{15}$ Corresponde à diferença entre o lucro líquido e o fluxo de caixa operacional líquido, ou ainda, todas aquelas contas de resultado que impactaram o lucro, mas que ainda tiveram efeito no caixa (MARTINEZ, 2008, p. 8).

${ }_{16}$ Tradução livre de: "A major motivation for research comparing alternative performance measures is perceived deficiencies in some of the performance measures".
} 
De acordo com Watts e Zimmerman (1986) pode-se avaliar a utilidade ou o conteúdo informacional do resultado a partir da investigação da relação entre preço das ações e resultado ou lucro (BALL; BROWN, 1968). Duas abordagens podem ser aplicadas para analisar o conteúdo informacional do resultado: i) resultado refletindo fatores que influenciam o preço das ações; e ii) anúncios de resultados conduzindo informação para o mercado de capitais. Na primeira, sob a hipótese do mercado eficiente ou efficient markets hypothesis (EMH), os participantes do mercado podem obter informação trimestralmente de fontes alternativas antes do anúncio dos resultados, por exemplo, a previsão de resultado dos analistas de mercado. Isso significa que, a observação de associação entre alterações nos resultados trimestrais e taxas de retornos anormais trimestrais, não indica, necessariamente, que o resultado revela informação para o mercado. Para verificar isso, é necessário observar o comportamento do preço das ações no período de anúncio dos resultados, enfoque da segunda abordagem.

A partir deste raciocínio, Ball e Brown (1968) investigaram a relação entre o sinal de resultados não esperados em anúncios anuais e os retornos anormais, em 261 empresas da New York Stock Exchange - NYSE. Os resultados não esperados podem ser entendidos como o resultado corrente menos o resultado esperado com base nos números do mercado. A pesquisa dos autores apoia-se na ideia de que, aumentos não esperados nos resultados são acompanhados por retornos anormais positivos, enquanto que as diminuições são associadas a retornos negativos. Para testar se o resultado reflete fatores que influenciam o preço das ações, os autores compararam o anúncio de resultados não esperados de sinal positivo (negativo) com o retorno anormal médio. Portanto, a hipótese de que os resultados possuem conteúdo informacional é testada a partir do retorno anormal médio para o período do anúncio. Os autores observaram que as alterações nos preços das ações ocorreram antes da publicação anual dos números contábeis e, por isso, não classificaram o resultado como uma fonte de informação altamente oportuna. O comportamento do preço no período anterior à divulgação das demonstrações contábeis anuais pode ser explicado pelos relatórios trimestrais, e por outras fontes de informação. Um teste foi realizado para avaliar a associação entre as duas variáveis do ponto de vista estatístico, confirmando a hipótese de que o resultado anunciado nas demonstrações contábeis anuais possui conteúdo informacional. Além disso, outras pesquisas realizadas após o estudo de Ball e Brown concluíram, com razoável segurança, que as variações nos resultados contábeis e nos preços das ações são relacionadas (WATTS; ZIMMERMAN, 1986, p. 40-47). 
Watts e Zimmerman (1986) realizaram um levantamento de vários trabalhos nesta linha e, entre os principais resultados, concluíram que, as evidências empíricas apontam para uma associação entre preço das ações e os resultados não esperados em termos de sinal e tamanho. No âmbito da EMH, este resultado é consistente com a hipótese de que, os números contábeis refletem fatores que afetam o preço das ações, e que os resultados possuem conteúdo informacional.

Os autores (1986 p. 129) também comentam sobre a literatura referente ao estudo do comportamento do resultado ao longo do tempo, mais especificamente, a busca de padrões com o propósito de prever o resultado contábil das empresas. Tal linha de pesquisa foi impulsionada, entre outros motivos, pelo interesse de pesquisadores na aplicação de modelos para avaliação de empresas, usando séries temporais de resultados.

Gordon (1964 apud WATTS E ZIMMERMAN, 1986, p. 135) contribuiu para esta linha de pesquisa ao estudar a variação do resultado ao longo tempo e os seus incentivos para tal. Segundo o autor, os administradores escolhem práticas contábeis para aumentar o resultado divulgado, e naturalmente a sua taxa de crescimento, além de buscarem uma diminuição na variância dos resultados. Esta expectativa baseia-se nas seguintes premissas:

- Os administradores maximizam sua utilidade;

- Os preços das ações são influenciados pelo nível, taxa de crescimento e dispersão dos resultados contábeis; e

- A remuneração dos administradores depende do valor da empresa.

Com base nestas premissas, alguns estudos surgiram com o objetivo de observar a suavização ou smooth dos resultados divulgados. Estas premissas têm implicações diretas para estudos de séries temporais do resultado. Contudo, não encontra-se na literatura uma teoria que explique o comportamento do resultado com base em padrões ou processos em particular, dificultando o estabelecimento de questões de pesquisa a partir de séries temporais do resultado (WATTS; ZIMMERMAN, 1986).

Apesar disso, as pesquisas que nasceram na linha da teoria positiva da contabilidade, segundo Watts e Zimmerman (1986), representam tentativas de explicar fenômenos contábeis. O lucro 
geralmente é visto como resultado de um conjunto de práticas ou escolha contábeis, representando um dos números mais importantes para a administração da empresa. O gestor pode escolher práticas contábeis que contribuam para aumentar ou diminuir o resultado, dependendo dos incentivos envolvidos. Por exemplo, se a remuneração variável da administração está vinculada ao resultado, ele pode escolher um conjunto de práticas que maximizem o valor presente dos resultados divulgados. A partir deste e de outros incentivos baseados em contratos, assumiu-se um comportamento esperado da administração com reflexo nas práticas contábeis adotadas e no resultado da organização, sendo que muitas pesquisas surgiram com o propósito de verificar empiricamente estas expectativas.

Um aspecto que merece destaque diz respeito à mudança de GAAP. Segundo Watts e Zimmerman (1986, p. 286) há varias implicações decorrentes de mudanças nas normas contábeis de natureza obrigatória, tanto para os usuários internos da contabilidade quanto para os externos. Por exemplo, “[...] se a empresa tem um plano de remuneração baseado em resultados, as mudanças obrigatórias reduzem a habilidade dos administradores em aumentar a sua remuneração por meio de métodos contábeis". A restrição em termos de normas contábeis pode balizar a transferência de riqueza por meio de contratos de remuneração, causando um pequeno aumento no preço das ações. No entanto, quando a mudança é de natureza voluntária, espera-se que o bônus da administração aumente e, portanto, produza impacto negativo no preço das ações.

\subsection{0 processo de convergência no mundo}

O objetivo desta seção é apresentar um panorama geral do processo de convergência para as IFRS no mundo, além de descrever os principais desafios enfrentados pelo IASB ao assumir este compromisso.

A contabilidade vista como linguagem dos negócios pode ser considerada como uma fonte de informação para os usuários externos, que precisam tomar uma decisão em relação aos seus investimentos. Os investidores podem buscar esta informação nas demonstrações contábeis das empresas. No entanto, os investidores internacionais podem ter alguma dificuldade ao compararem as demonstrações contábeis de países que adotam sistemas contábeis diferentes, isto é, que possuem práticas contábeis distintas. Portanto, a ausência de uniformidade nas práticas contábeis representa um importante incentivo para o processo de harmonização 
contábil internacional, visando uma compreensão mais adequada desta linguagem (NIYAMA, 2008).

Em função das diferenças em termos de práticas contábeis, alguns estudos (NOBES, 1992; DOUPNIK; SALTER, 1993) se dispuseram a desenvolver classificações para os diversos sistemas contábeis. De acordo com Nobes (1992), os principais critérios utilizados na classificação são: sistema político, econômico, estágio de desenvolvimento da economia, objetivos da divulgação das demonstrações contábeis, regulação e fiscalização das normas contábeis, e educação. $\mathrm{O}$ autor explica as principais razões para tal classificação:

[...] a classificação deve ser uma forma eficiente de descrever e comparar diferentes sistemas. Ela deve ajudar a mapear o progresso de um país que se move de um sistema para o outro, e o progresso das ideias de um sistema dominante, observando os outros sistemas nacionais existentes ao redor (NOBES, 1992, p. 55) ${ }^{17}$.

Sendo assim, o principal motivo para desenvolver uma classificação dos sistemas contábeis deve-se ao interesse em explicar as diferenças entre os próprios sistemas, além de investigar as alterações nas práticas contábeis denominadas pelo autor de progresso.

$\mathrm{Na}$ verdade, o incentivo para estudar as alterações nos padrões contábeis surgiu logo após a segunda guerra mundial, por meio de uma tendência expansionista de alguns países. Neste contexto de crescente internacionalização e liberalização dos mercados de capital e crédito, houve um aumento no número de transações entre países, os quais possuíam sistemas contábeis diferentes e, consequentemente, regras contábeis de reconhecimento, mensuração e divulgação divergentes. Naturalmente, surgiu uma preocupação por parte dos agentes de mercado, principalmente os investidores, ao observar demonstrações contábeis tão distintas, o que impedia ou dificultava a comparação dos relatórios contábeis dos países. Nos anos 70 um grupo de países se juntou com o objetivo de produzir um conjunto de normas contábeis internacionais, assegurando aos investidores relatórios contábeis transparentes e comparáveis.

Estas normas contábeis internacionais ou IFRS, atualmente, são emitidas pelo IASB, uma organização independente com sede em Londres, as quais podem ser aplicadas por diversas empresas ao redor do mundo. Porém, é importante destacar que, entre 1973 e 2000, as normas

\footnotetext{
${ }^{17}$ Tradução livre de: "Classification should be an efficient way of describing and comparing different systems. It should help to chart the progress of a country as it moves from use of one system to another, and the progress of ideas of a dominant country's system by noting the other national systems grouped around it".
} 
internacionais foram emitidas pelo IASC, uma organização antecessora ao IASB, formada pelos países Austrália, Canadá, França, Alemanha, Japão, México, Holanda, Reino Unido e Estados Unidos, sendo que, neste período as normas emitidas eram denominadas de IAS. Porém, desde abril de 2001 as normas são desenvolvidas pelo IASB (BALL, 2006).

Nos últimos anos, o IASB tem realizado notável esforço para difundir as normas internacionais pelo mundo, e algumas consequências deste trabalho são:

i) Mais de 120 países já adotam as IFRS;

ii) Todas as empresas dos países membros da União Europeia foram obrigadas a divulgar as demonstrações contábeis consolidadas de acordo com as IFRS a partir de 2005;

iii) Alguns países estão substituindo gradualmente o GAAP nacional pelas IFRS;

iv) Outros países adotaram uma política de revisão das IFRS para, em seguida, adotá-las na íntegra ou com pequenas modificações;

v) A IOSCO recomendou aos seus membros a aceitação de emissores estrangeiros que divulgam suas demonstrações contábeis em IFRS.

Estas consequências refletem o trabalho do IASB em promover as normas internacionais de contabilidade visando à convergência. Diversos países que ainda não adotaram as normas internacionais possuem projetos de convergência, que poderão conduzir o país à aceitação das IFRS. A tabela 2 contém os países do Grupo dos 20 (G20) e seus respectivos planos de convergência às IFRS. Por exemplo, a Argentina exigiu a adoção das IFRS a partir de $1^{\circ}$ de janeiro de 2012, enquanto a Índia possui um projeto de convergência sem data determinada. 
Tabela 2 - Países e seus respectivos planos de convergência para as IFRS

\begin{tabular}{|c|c|}
\hline Países & Situação quanto aos planos de convergência para as IFRS \\
\hline Argentina & Obrigatório a partir de 1 de janeiro de 2012 \\
\hline Austrália & $\begin{array}{l}\text { Obrigatório para todas as empresas do setor privado e como base para a divulgação do setor } \\
\text { público desde } 2005\end{array}$ \\
\hline Brasil & $\begin{array}{l}\text { Obrigatório para as demonstrações contábeis consolidadas de bancos e companhias abertas a } \\
\text { partir de } 31 \text { de dezembro de } 2010 \text {, e para as demonstrações contábeis individuais, } \\
\text { progressivamente, desde janeiro de } 2008\end{array}$ \\
\hline Canadá & $\begin{array}{l}\text { Obrigatório a partir de } 1 \text { Janeiro de } 2011 \text { para todas as companhias abertas e permitido para } \\
\text { entidades do setor privado, incluindo aquelas sem fins lucrativos }\end{array}$ \\
\hline China & As empresas já adotam as IFRS \\
\hline $\begin{array}{l}\text { União } \\
\text { Europeia }\end{array}$ & Todos os Estados membros da UE são obrigados a adotar as IFRS desde 2005 \\
\hline França & Obrigatório desde 2005 \\
\hline Alemanha & Obrigatório desde 2005 \\
\hline Índia & A Índia declarou interesse em adotar as IFRS, mas ainda não confirmou uma data \\
\hline Indonésia & $\begin{array}{l}\text { Processo de convergência em curso, uma decisão sobre uma data para a plena conformidade } \\
\text { com as IFRS deverá ocorrer em } 2012\end{array}$ \\
\hline Itália & Obrigatório desde 2005 \\
\hline Japão & $\begin{array}{l}\text { Permitida a partir de } 2010 \text { para algumas empresas internacionais; decisão sobre a adoção } \\
\text { obrigatória até } 2016\end{array}$ \\
\hline México & Obrigatório a partir de 2012 \\
\hline $\begin{array}{l}\text { República da } \\
\text { Coréia }\end{array}$ & Obrigatório a partir de 2011 \\
\hline Rússia & Obrigatório a partir de 2012 \\
\hline $\begin{array}{l}\text { Arábia } \\
\text { Saudita }\end{array}$ & $\begin{array}{l}\text { Obrigatório para empresas bancárias e de seguro. A convergência total com as IFRS ainda está } \\
\text { em estudo }\end{array}$ \\
\hline África do Sul & Obrigatório para as companhias abertas desde 2005 \\
\hline Turquia & Obrigatório para as companhias abertas desde 2005 \\
\hline Reino Unido & Obrigatório desde 2005 \\
\hline $\begin{array}{l}\text { Estados } \\
\text { Unidos }\end{array}$ & $\begin{array}{l}\text { Permitido para os emissores estrangeiros nos EUA desde 2007, data-alvo para a convergência } \\
\text { para as IFRS é } 2012\end{array}$ \\
\hline
\end{tabular}

FONTE: IFRS Foundation; 2012.

Enquanto alguns países decidiram adotar as normas contábeis internacionais prontamente com pouca ou nenhuma resistência, outros, como os Estados Unidos, apresentam uma incerteza em relação ao processo de convergência. A SEC declarou que decidiria em 2011 sobre a adoção obrigatória das IFRS, porém o uso efetivo do padrão internacional pelas empresas norteamericanas estava previsto para 2015 ou 2016. Para possibilitar a convergência do padrão norte-americano ao internacional, a SEC e o IASB estabeleceram uma extensa agenda de projetos em conjunto, com previsão para término em junho de 2011. A SEC declarou que este trabalho seria uma etapa importante para a sua decisão em relação a requerer ou não o padrão internacional. No entanto, o crescimento de países adotando as IFRS, inclusive subsidiárias das empresas norte-americanas em outros países, revelou uma oportunidade para as empresas dos Estados Unidos se integrarem à divulgação das demonstrações contábeis, facilitando a realização de negócios entre diversos países (KPMG, 2010). 
Uma evidência disto foi apresentada por Yip (2010), que constatou um aumento no número de fusões e aquisições entre os países adotantes das IFRS, sugerindo que as normas internacionais facilitam a realização destas operações.

Diante da possibilidade de obter estes benefícios, a SEC anunciou um plano de trabalho voltando para seis áreas específicas:

- Determinar se há suficiente desenvolvimento e consistência na aplicação das IFRS para uso no sistema de divulgação dos EUA, incluindo uma análise da abrangência, aplicabilidade e comparabilidade das demonstrações contábeis em IFRS dentro do país e em relação a outros países;

- Assegurar a independência do órgão normatizador das IFRS, incluindo sua estrutura de governança, responsabilidade e financiamento;

- Avaliar a compreensão dos investidores e a educação em IFRS;

- Entender como outros processos de regulação, tais como tributos e relatórios de outros órgãos reguladores, seriam afetados por uma mudança nos padrões;

- Entender o efeito sobre os sistemas contabilidade das empresas, disposições contratuais, governança corporativa, contingências judiciais, incluindo a compreensão do impacto sobre as grandes e pequenas empresas; $\mathrm{e}$

- Determinar se os responsáveis pela elaboração das demonstrações contábeis, auditores e usuários são suficientemente capazes de fazer a conversão para as IFRS (KPMG, 2010).

Apesar da apresentação deste plano de trabalho e da agenda de projetos em conjunto com o IASB, alguns pontos permanecem em discussão e sem alcançar um consenso nos últimos anos, atrasando a adoção das normas internacionais pelos Estados Unidos. Um destes pontos é representado pelos instrumentos financeiros, que possui algumas diferenças de tratamento entre os dois sistemas contábeis. Apesar disso, há um esforço das duas partes em tentar aproximar a regra contábil de instrumentos financeiros, pois enquanto o IASB estuda uma mudança na IFRS 9, regra contábil internacional sobre instrumentos financeiros, o FASB mostra uma flexibilidade ao recuar de uma proposta apresentada em 2010, que sustentava a contabilização a valor de mercado de praticamente todos os ativos e passivos financeiros (TORRES, 2011). 
Mais recentemente, a SEC emitiu um relatório denominado Work Plan for the Consideration of Incorporating International Financial Reporting Standards into the Financial Reporting System for U.S. Issuers, no qual são apresentadas observações e análises sobre as seis áreas identificadas anteriormente no plano de trabalho. A SEC ressalta que o relatório não implica na aceitação das IFRS pelos Estados Unidos, pois embora o seu conteúdo represente uma contribuição importante para o processo de convergência, o mesmo não tratou dos interesses dos mercados de valores mobiliários e investidores norte-americanos. O órgão ainda declarou que uma análise adicional sobre questões políticas é necessária antes de qualquer decisão sobre a convergência (SEC, 2012).

Em resposta ao relatório da SEC, os curadores ${ }^{18}$ da IFRS Foundation publicaram uma nota afirmando que

[...] o relatório reitera os diversos desafios que uma economia grande como os Estados Unidos enfrenta ao fazer a transição para as IFRS - desafios que outras jurisdições superaram com êxito ao completar a sua transição para as IFRS [...]. Embora se reconheça o direito da SEC em determinar o método e o período para a incorporação das IFRS nos Estados Unidos, lamentamos que o relatório da equipe não seja acompanhado por um plano de ação (IFRS, 2012).

O comunicado revela uma insatisfação dos curadores em relação ao relatório publicado pela SEC, pois é sabido que a convergência da maior economia do planeta poderia reforçar o processo de convergência de outros países.

\subsection{O processo de convergência no Brasil}

O objetivo da seção é descrever brevemente o processo de convergência no Brasil, destacando suas peculiaridades em relação a outros países.

Antes do processo de convergência das normas contábeis brasileiras ao padrão internacional, a contabilidade societária era influenciada pelas normas da Secretaria da Receita Federal, agências reguladoras, fiscalizadoras e associações de profissionais. Como resultado, as demonstrações contábeis não eram elaboradas de acordo com as disposições técnicas

\footnotetext{
${ }^{18}$ Curadores da Fundação IFRS ou IFRS Foundation Trustees.
} 
conhecidas mais adequadas, gerando uma perda na qualidade da informação contábil. Neste cenário, surgiu uma forte pressão de acadêmicos, profissionais ligados ao mercado e outros agentes para centralizar a normatização contábil no Brasil, buscando a convergência às normas internacionais de contabilidade emitidas pelo IASB. Um dos principais resultados foi a criação do Comitê de Pronunciamentos Contábeis - CPC, cujo principal objetivo é produzir normas em consonância ao padrão internacional (IUDÍCIBUS et al 2010).

Diferentemente dos países da União Europeia, que adotaram obrigatoriamente todas as IFRS/IAS a partir de 2005, as empresas brasileiras foram obrigadas a adotar as normas internacionais em duas fases. A primeira fase se deu com a adoção de alguns Pronunciamentos Técnicos - correlacionados com as normas internacionais de contabilidade - nas demonstrações contábeis de 2008 e 2009; a segunda fase ocorreu a partir da adoção de todos os Pronunciamentos Técnicos nas demonstrações contábeis de 2010, resultando na adoção das IFRS em duas etapas. Como não há relatos de casos similares, o processo de convergência brasileiro pode ser caracterizado como único, despertando interesse em investigar se as consequências econômicas observadas em outros casos se aplicam ao Brasil. Portanto, diante destes aspectos pode-se caracterizar o caso brasileiro como um modelo híbrido.

A primeira etapa tem início com a emissão da deliberação no 565 de 2008 pela CVM, que aprovou o Pronunciamento Técnico CPC 13 - pronunciamento válido apenas para 2008. O objetivo do CPC 13 era regular a introdução de um novo conjunto de princípios e práticas contábeis com base nas IFRS. Para alcançá-lo, o pronunciamento, após aprovação da CVM, exigiu que as empresas adotassem a Lei no 11.638/07 e a Medida Provisória no 449/08 - atual Lei $\mathrm{n}^{\mathrm{o}}$ 11.941/09 - além das normas contábeis emitidas pelo Comitê de Pronunciamentos Contábeis (CPC), aprovadas pela CVM. Estas Leis tiveram como principal objetivo atualizar a legislação societária para possibilitar o processo de convergência das práticas contábeis adotadas no Brasil. Outra importante contribuição da Lei no $11.638 / 07$ é dada pela eliminação da influência da legislação fiscal nas demonstrações contábeis das companhias abertas. A Lei $n^{\circ}$ 11.941/09 reforçou esta segregação pela criação do Regime Tributário de Transição - RTT, isentando as novas práticas contábeis introduzidas pelos CPCs para fins de tributação. Em resumo, as demonstrações contábeis brasileiras dos exercícios sociais 2008-2009 passaram a atender parcialmente as IFRS. 
Em dezembro de 2010, a CVM emitiu a deliberação $n^{\circ} 647$ que exigiu a adoção do CPC 37 (R1) - Adoção Inicial das Normas Internacionais de Contabilidade - para as companhias abertas, iniciando a segunda etapa do processo de convergência. Este Pronunciamento Técnico é aplicado quando a entidade adota as IFRS pela primeira vez, e, naturalmente, exigiu a adoção de todos os CPCs e IFRSs vigentes em 2010 nas demonstrações contábeis consolidadas. Assim, a transição de GAAP é concluída, permitindo que as empresas divulguem seus relatórios contábeis full IFRS.

É importante destacar que outros atos normativos da CVM voltados para o processo de convergência antecedem as deliberações citadas. Por exemplo, a instrução n ${ }^{\circ} 457$ de 2007 determinou a elaboração e divulgação das demonstrações financeiras consolidadas a partir de 2010, com base no padrão contábil internacional para as empresas de capital aberto. Além disto, esta instrução também permitiu a adoção antecipada das normas internacionais até o exercício social de 2009.

No entanto, considerando os imprevistos ocorridos no plano de trabalho conjunto entre CPC e CVM, a deliberação no 603 de 2009 permitiu a apresentação das demonstrações contábeis trimestrais de 2010 de acordo com as normas contábeis vigentes até 31 de dezembro de 2009. Segundo comunicado ${ }^{19}$, a CVM declarou que muitas companhias teriam dificuldades em aplicar todos os CPCs a partir da $1^{\text {a }}$ Informação Trimestral de 2010. Em compensação, a deliberação $n^{\circ} 603$ exigiu a divulgação dos relatórios trimestrais de 2010 quando da divulgação das demonstrações contábeis do exercício social de 2010. Portanto, a aplicação e evidenciação de todos os CPCs, a partir da $1^{\text {a }}$ Informação Trimestral de 2010 pode ser considerada uma prática voluntária, visto que a deliberação comentada facultou a adoção plena das IFRS.

\subsection{Informação Contábil e Aspectos Institucionais}

O objetivo desta seção é destacar os incentivos que atuam no processo de convergência às IFRS, os quais podem influenciar a qualidade das demonstrações contábeis.

\footnotetext{
19 
Em 2006, o ex-presidente do IASB David Tweedie declarou que a adoção das IFRS pode contribuir para "[...] reduzir o custo de capital e abrir novas oportunidades de diversificação e melhorar retornos de investimento" ${ }^{20}$ (TWEEDIE, 2006). Além disto, as empresas que operam em vários países podem reduzir os custos de preparação e elaboração dos relatórios contábeis de acordo com vários GAAPs.

Mais recentemente, o atual presidente Hans Hoogervorst, em carta divulgada no site IFRS que oficializa seu mandato, complementa:

[...] não seremos capazes de agradar a todos, mas eu acredito que estamos no caminho certo para oferecer normas baseadas em princípios de alta qualidade que aumentam a transparência para os investidores e outros usuários das demonstrações contábeis $^{21}$ (IFRS, 2011).

Ambos destacam as vantagens decorrentes da adoção das normas internacionais, porém o atual presidente reconhece a impossibilidade de agradar a todos os países. Essa observação é corroborada por alguns acadêmicos que ressaltam os problemas decorrentes de um único conjunto de práticas contábeis (BALL, 2006; WALKER; 2010).

Neste sentido, pode-se citar o estudo de Burgstahler, Hail e Leuz (2006), que analisa os principais incentivos do baixo conteúdo informacional proporcionado pela contabilidade, prejudicando a análise dos stakeholders. Os principais incentivos comentados pelos autores são: forças do mercado de capitais e qualidade do enforcement. No que diz respeito às forças de mercado, os autores comentam que as empresas listadas em bolsa possuem uma elevada demanda por informações, as quais podem ser usadas para fins de avaliação e monitoramento. Porém, se a qualidade da informação é insuficiente para as atividades de avaliação e monitoramento, os investidores serão relutantes em investir seus recursos na empresa. Consequentemente, as empresas listadas em bolsa têm fortes incentivos para divulgar demonstrações contábeis que auxiliem os investidores a avaliar o desempenho econômico da empresa.

\footnotetext{
${ }^{20}$ Tradução livre de: "reduce the cost of capital and open new opportunities for diversification and improved investment returns".

${ }^{21}$ Tradução livre de: "we will not be able to please everyone, but I believe we are on the right path to deliver high quality, principle-based standards that enhance transparency to investors and other users of financial statements".
} 
O segundo conjunto de incentivos é fruto de uma abordagem institucional promovida pelos autores, baseando-se em La Porta et al (1997), La Porta, Lopes-de-Silanes e Shleifer (1998), e La Porta, Lopes-de-Silanes e Shleifer (1999). Estas obras identificaram que o ambiente legal, caracterizado pelas suas normas e grau de enforcement, é importante para o desenvolvimento do mercado de capitais, pois um ambiente jurídico que oferece proteção aos investidores contra a expropriação de riqueza pode atrair mais recursos para as empresas, contribuindo para expandir o mercado de capitais. Além disso, observou-se que a proteção legal concedida aos investidores é diferente entre os países, principalmente entre aqueles de origem legal code law e common law ${ }^{22}$, explicando a origem de recursos para financiamento das empresas.

O trabalho de Ball (2006) também analisa os determinantes da qualidade das demonstrações contábeis no contexto do processo de convergência às IFRS. O autor acredita que o processo de implementação das normas internacionais ocorre de forma desigual devido às razões políticas e econômicas. Apesar do incremento da globalização, a maior parte da influência econômica e política sobre os relatórios financeiros é demasiadamente local. Assim, a adoção das IFRS por vários países pode induzir os investidores ao erro, visto que, estes acreditam em maior uniformidade dos relatórios contábeis por seguirem o mesmo padrão contábil, quando na verdade, a qualidade das demonstrações contábeis pode ser diferente entre os países adotantes das IFRS. Porém, o poder das forças políticas e econômicas pode determinar como os administradores, auditores, reguladores e outras partes influenciam a aplicação das normas contábeis. Neste cenário, é necessário diferenciar a uniformidade de padrões contábeis daquela associada ao comportamento na divulgação das demonstrações contábeis. Enquanto a primeira é mais fácil de ser obtida, a segunda requer uma mudança radical na atuação dos agentes econômicos e políticos que podem influenciar o nível de enforcement de implementação das IFRS.

Por sua vez, Soderstrom e Sun (2007) também investigam os aspectos que influenciam a mudança de GAAP. Uma justificativa para o trabalho reside no interesse dos autores em investigar as mudanças substanciais que ocorrem no ambiente de negócios de diversos países, os quais abandonaram os seus GAAPs locais para adotar as IFRS. Portanto, eles analisam as

\footnotetext{
${ }^{22}$ As leis e normas dos diferentes países são originadas de poucas tradições legais. Elas são originadas normalmente de duas abordagens tradicionais: common law que é de origem inglesa, e civil law que deriva do direito romano (LA PORTA; LOPES-DE-SILANES; SHLEIFER, 1998).
} 
consequências de alterações nos princípios contábeis e os determinantes da qualidade da informação.

Soderstrom e Sun (2007) afirmam que a superioridade no ambiente informacional proporcionado pelas IFRS é apoiada em dois fatores: i) a premissa de que as IFRS determinam demonstrações contábeis de elevada qualidade, reforçada por evidências empíricas acerca do desenvolvimento da informação contábil (BARTH; LANDSMAN; LANG, 2008); e ii) o sistema contábil de um país representa apenas uma parcela do sistema institucional de um país, portanto, há outros incentivos que devem ser considerados ao investigar a divulgação das demonstrações contábeis. Como exemplo, o autor cita as evidências empíricas de La Porta et al (1998), que constataram sistema contábil e proteção aos investidores superiores nos países de origem common law em relação aos code law. Além disso, citam outros fatores: tributos, estrutura de propriedade, política, estrutura de capital, e desenvolvimento de mercado de capitais. A ilustração a seguir demonstra os determinantes da qualidade da informação contábil. 


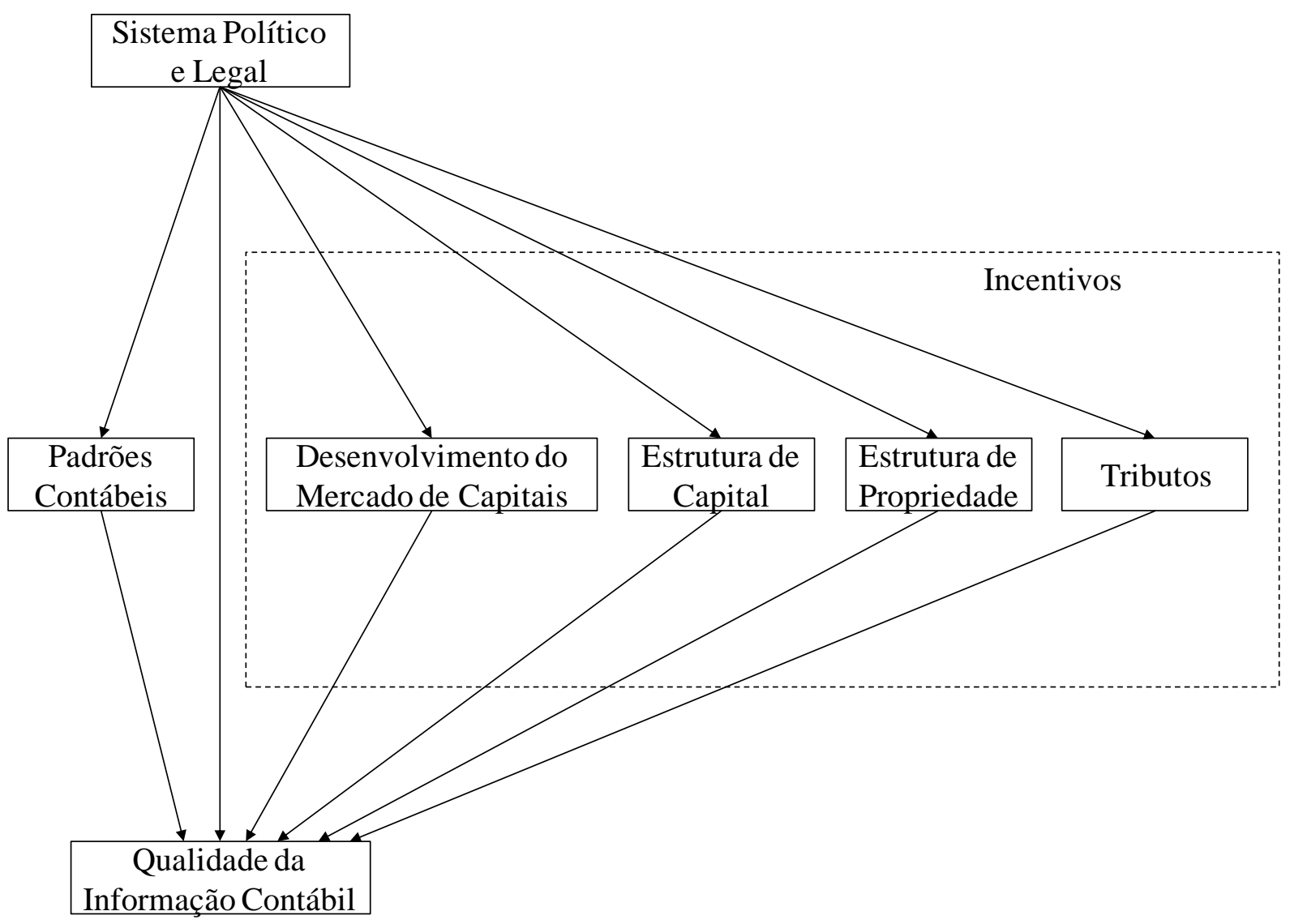

Ilustração 3- Determinantes da Qualidade Contábil FONTE: SODERSTROM; SUN, 2007.

Assim, como pode ser observado pela ilustração anterior, embora grande parte da literatura assuma que a convergência do GAAP nacional para as IFRS contribua para aumentar a qualidade da informação contábil, este aspecto, na verdade, representa apenas um dos determinantes.

\subsection{Conteúdo Informacional}

O principal objetivo desta seção é apresentar a fundamentação para o estudo do conteúdo informacional ou qualidade das demonstrações contábeis.

O conteúdo informacional ou qualidade da informação contábil pode ser investigado a partir do Pronunciamento Conceitual Básico (R1) ou PCB, que contém a estrutura conceitual para a elaboração e apresentação das demonstrações contábeis. Este documento é a base para todas as normas contábeis. O PCB estabelece que o objetivo das demonstrações contábeis seja 
fornecer informações sobre a posição patrimonial e financeira da entidade, que sejam úteis a um grande número de usuários. A partir disso, a utilidade das demonstrações contábeis pode ser analisada pelas suas características qualitativas: relevância, materialidade, representação fidedigna, comparabilidade, verificabilidade, tempestividade e compreensibilidade. Por exemplo, a relevância é definida no item QC6 do PCB:

[...] informação contábil-financeira relevante é aquela capaz de fazer diferença nas decisões que possam ser tomadas pelos usuários. A informação pode ser capaz de fazer diferença em uma decisão mesmo no caso de alguns usuários decidirem não a levar em consideração, ou já tiver tomado ciência de sua existência por outras fontes.

Com base nesta definição, pode-se desenvolver métodos de observação do aspecto relevância, que permitam concluir sobre a sua presença ou não no conjunto das demonstrações contábeis. Sendo assim, é fundamental delimitar a análise da estrutura conceitual para o estudo das características qualitativas das demonstrações contábeis. A ilustração a seguir oferece uma visão esquemática desta relação.

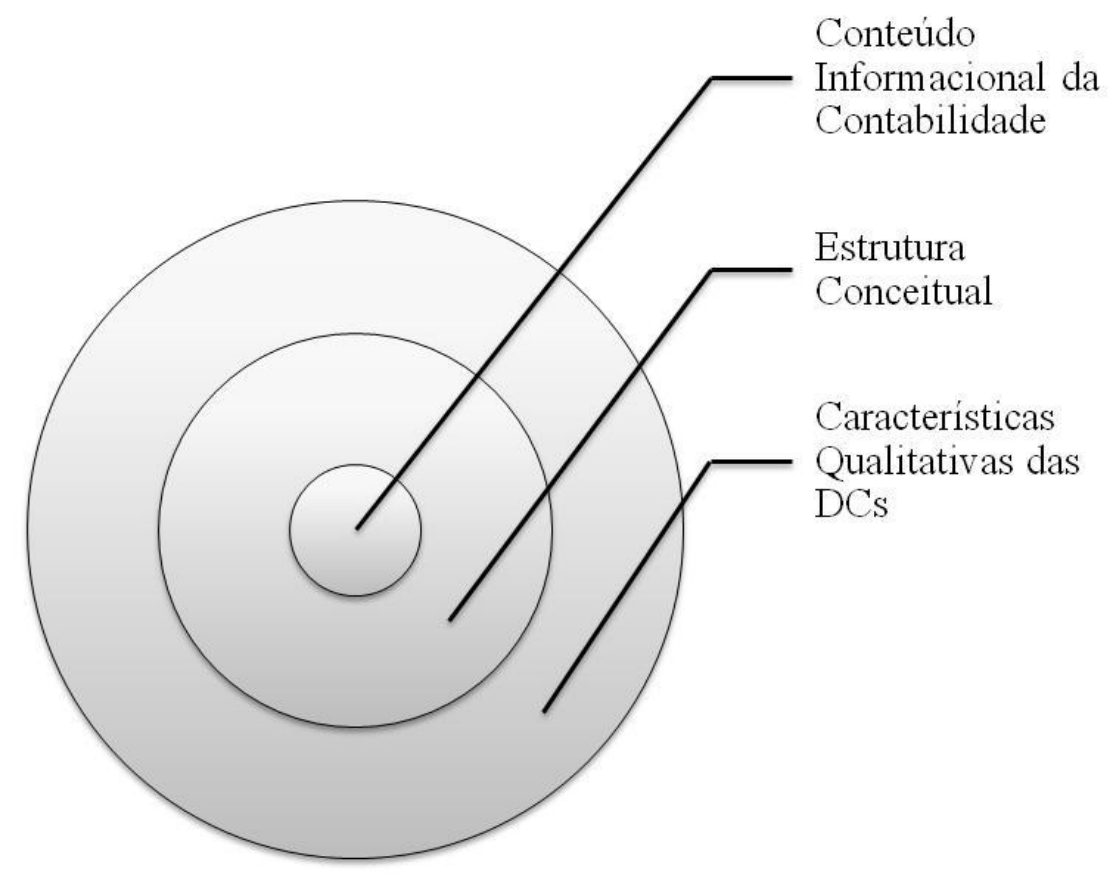

Ilustração 4 - Visão esquemática da relação entre conteúdo informacional, estrutura conceitual e características qualitativas das demonstrações contábeis.

Na literatura pode-se encontrar muitos estudos com o propósito de observar qualidade da contabilidade. Os autores Francis, Olsson e Schipper (2008), por exemplo, apresentam uma revisão de estudos relacionados à qualidade dos resultados ou earnings quality - EQ, 
incluindo definiçõoes e mensurações de métricas para EQ, tendo como enfoque principal o mercado de capitais.

Segundo os autores, a qualidade da informação é vinculada à precisão, pois eles entendem que a informação de alta qualidade é mais precisa, isto é, não contém incertezas. No entanto, eles reconhecem que a ideia de precisão, no contexto de mercado de capitais, deve ser restringida a alguns aspectos. Tais aspectos podem ser encontrados na estrutura conceitual do FASB, mas especificamente, nas características qualitativas das demonstrações contábeis, as quais são consideradas como atributos da qualidade da informação. No entanto, Francis, Olsson e Schipper (2008, p. 268) reconhecem que "[...] se a qualidade engloba qualquer atributo que torne a informação valiosa para participantes do mercado, então, uma caracterização completa da qualidade da informação é empiricamente intratável”.

Neste sentido, os autores afirmam que a qualidade do resultado é um conceito multidimensional, sendo que algumas medidas são vinculadas à percepção dos investidores. Por exemplo, as pesquisas que investigam a relevância dos números contábeis, assumem que o preço de mercado ou retorno da ação reflete o julgamento dos investidores a respeito de tais números.

Recentemente, o desenvolvimento e a aplicação das IFRS também estimularam o crescimento da literatura EQ. O objetivo, explicitamente declarado pelo IASB, que fundamenta-se no desenvolvimento de um conjunto de normas contábeis de alta qualidade, tem despertado o interesse de pesquisadores sobre questões relacionadas à EQ. Além disso, a adoção das IFRS tem gerado interesse por parte dos pesquisadores na comparação de práticas contábeis entre os países (DEFOND, 2010). Nas próximas seções algumas abordagens comumente utilizadas para avaliar as características qualitativas da contabilidade são apresentadas, sendo elas: i) gerenciamento de resultados; ii) conservadorismo; iii) relevância e tempestividade.

\subsection{Gerenciamento de Resultados}

O objetivo desta seção é descrever os principais aspectos da abordagem voltada para observar o gerenciamento de resultado. 
Espera-se que as demonstrações contábeis permitam aos usuários uma visão da realidade econômico-financeira da empresa. No entanto, o resultado contábil observado nas demonstrações contábeis é fruto de um conjunto de eventos reconhecidos por diversas práticas contábeis. Em alguns casos pode-se utilizar práticas diferentes ao observar os mesmos eventos econômicos, fornecendo incentivo para buscar evidências empíricas acerca da utilidade dos números contábeis (BALL; BROWN, 1968).

Neste sentido, a subjetividade presente nas normas contábeis pode ser usada com o propósito de refletir a realidade econômica da empresa ou atingir propósitos específicos. Na verdade, os accruals podem ser manipulados em função do grande poder discricionário dos administradores, permitindo práticas de gerenciamento de resultado. Segundo Lopes e Martins (2005) há incentivos internos e externos para que os administradores manipulem os resultados.

Os autores Fields, Lys e Vicent (2001) explicam que a prática de gerenciamento de resultados pode abranger as escolhas contábeis, as quais são originadas por decisões tomadas com o propósito de influenciar as informações geradas pelo sistema contábil, incluindo as demonstrações financeiras e os relatórios de natureza fiscal e regulatória.

Neste contexto, muitos autores concordam que as normas contábeis permitem métodos de avaliação, estimativas contábeis e formas de divulgação diferentes, demonstrando o grande valor que a contabilidade possui como forma de comunicação. Porém, devido às imperfeições da auditoria, os administradores podem ver o exercício de julgamento como uma oportunidade para gerenciar resultados, ocasionando na escolha de práticas contábeis que não condizem com a situação econômica da empresa (HEALY; WAHLEN, 1999).

Assim, ao observar que o resultado contábil não necessariamente reflete a realidade econômico-financeira da entidade, pode-se comprometer a qualidade da informação contábil (MARTINEZ, 2008).

Os autores Healy e Wahlen (1999) realizaram uma revisão de estudos sobre gerenciamento de resultado, com o objetivo de auxiliar os reguladores a avaliarem a difusão da prática de gerenciamento e suas implicações sobre a integridade das demonstrações contábeis. Enquanto há evidências empíricas de gerenciamento de resultado na divulgação das demonstrações 
contábeis, mais especificamente no resultado líquido das empresas, é também observado que este mesmo número é relevante e, normalmente, mais adequado para fins de previsão dos fluxos de caixa futuros em comparação aos fluxos de caixa correntes (HEALY; WAHLEN, 1999).

Além disso, encontra-se na literatura uma classificação de práticas que configuram gerenciamento de resultado: conservadora - reconhecimento agressivo de provisões e reservas, supervalorização de despesas de reestruturação, baixa de ativos etc.; neutra resultados que derivam de um processo imparcial; e agressiva - subavaliação de provisões para clientes inadimplentes, usando as provisões ou reservas de uma maneira agressiva (DECHOW; SKINNER, 2000).

No Brasil, Martinez (2001) investigou se as empresas brasileiras de capital aberto realizam a prática de gerenciamento de resultados. Entre os principais resultados, o autor observou que as empresas brasileiras: i) gerenciam o resultado para evitar perdas, sendo que as empresas com maior endividamento estão mais propensas a tal prática; ii) há fraca evidência de gerenciamento para manter o desempenho recente; iii) as contas de depreciação, despesa com provisão de devedores duvidosos e receita não operacional ${ }^{23}$ contribuem para reduzir a variabilidade dos resultados; iv) para manter a credibilidade diante de credores, as empresas podem usar de contas de depreciação e receita não operacional para diminuir resultados negativos; v) diminuição de resultados correntes com o propósito de aumentar os resultados futuros; e vi) as empresas que fazem gerenciamento de resultado conseguem obter retorno anormal no curto prazo, porém no longo prazo o mercado identifica a prática de gerenciamento.

\subsection{Conservadorismo Condicional}

O objetivo desta seção é explicar brevemente o conservadorismo condicional, demonstrando a sua utilidade para os usuários da contabilidade.

\footnotetext{
${ }^{23}$ Atualmente, estas contas sao conhecidas como Perdas Estimadas com Créditos de Liquidação Duvidosa (PECLD) e Outras Receitas.
} 
Em primeiro lugar, deve-se diferenciar conservadorismo condicional e incondicional. $\mathrm{O}$ conservadorismo condicional ocorre pela antecipação de alguns eventos, os quais implicam na possibilidade de perdas. Por outro lado, o conservadorismo incondicional independe de perdas econômicas, pois a persistente subavaliação dos ativos e superavaliação dos lucros futuros podem levar à criação de reservas ocultas permanentes não conectadas às perdas econômicas (COELHO, 2007).

A expressão loss recognition ou reconhecimento de perdas provém da abordagem de estudos sobre o impacto do conservadorismo na informação contábil. Basu (1997, p. 4) define conservadorismo como:

[...] é a captura de uma tendência em exigir um grau maior de verificação para o reconhecimento de boas notícias em relação às más notícias nas demonstrações contábeis. Neste sentido, o resultado refletirá as más notícias mais rapidamente do que uma boa notícia. Por exemplo, as perdas não realizadas são normalmente reconhecidas mais cedo do que os ganhos. Esta assimetria de reconhecimento leva às diferenças sistemáticas na oportunidade e persistência dos resultados ${ }^{24}$.

$\mathrm{Na}$ literatura de conservadorismo encontram-se vários enfoques voltados para identificar o reconhecimento assimétrico de ganhos e perdas em determinado contexto. Por exemplo, Ball, Kothari e Robin (2000) investigaram se as propriedades da informação contábil, notadamente timeliness e conservadorismo, variam de acordo com as características institucionais dos países, por exemplo, a origem legal: code law ou common law. Segundo os autores, nos países de common law o resultado contábil é mais oportuno, pois incorpora de maneira mais tempestiva as perdas econômicas. Portanto, restringindo a transparência das demonstrações contábeis das empresas apenas a estas propriedades da informação contábil, espera-se que as empresas de origem common law apresentem relatórios contábeis mais informativos, levando a uma menor assimetria de informação. Os países usados na amostra de origem common law são: Austrália, Canadá, Reino Unido e Estados Unidos; enquanto que os de origem code law são: França, Alemanha e Japão.

Neste último grupo prevalece o modelo de governança corporativa voltado para os stakeholders. Algumas características deste grupo são: i) forte influência política na

\footnotetext{
${ }^{24}$ Tradução livre de: “I interpret conservatism as capturing accountants' tendency to require a higher degree of verification for recognizing good news than bad news in financial statements. Under my interpretation of conservatism, earnings reflects bad news more quickly than good news. For instance, unrealized losses are typically recognized earlier than unrealized gains. This asymmetry in recognition leads to systematic differences between bad news and good news periods in the timeliness and persistence of earnings".
} 
elaboração das normas contábeis; ii) enfoque no resultado como remuneração às partes contratuais, por exemplo, dividendo para acionistas, salário para administradores, tributo para governo etc.; iii) como os usuários da contabilidade apresentam menor demanda por informação contábil, há menos incentivo à divulgação; iv) os administradores possuem grande poder discricionário, que pode ser utilizado para reduzir a volatilidade do resultado. No outro conjunto de países, de origem common law, prevalece o modelo de governança orientado para os shareholders. Uma das principais características deste modelo é o foco na divulgação da informação contábil, que pode ser uma solução para redução da informação assimétrica. Os autores consideram também que, o desenvolvimento de práticas de governança corporativa, pode ter contribuído para aumentar ou diminuir as diferenças na qualidade da informação contábil dos países analisados. Os achados revelam que os países de origem code law apresentam números contábeis menos tempestivos e conservadores em relação aos de origem common law, consistente com a hipótese dos autores.

No cenário brasileiro, pode-se citar o trabalho de Coelho (2007) que investigou o conservadorismo condicional. Os resultados indicam que o conservadorismo não é praticado pelas companhias, implicando na inexistência de qualidade da informação contábil no que diz respeito a este aspecto. Além disso, o autor observou indícios de gerenciamento de resultados.

\subsection{Relevância da Informação Contábil}

O objetivo desta seção é apresentar uma revisão dos principais estudos ou métodos empregados na análise da relevância da informação contábil, além de consolidar os principais achados relacionados a esta dimensão da qualidade da informação.

O termo value relevance foi usado pela primeira vez por Amir, Harris e Venuti (1993), que investigaram a relevância das reconciliações entre as demonstrações contábeis de acordo com o GAAP de um determinando país e as demonstrações contábeis de acordo com os USGAAP. Os resultados indicaram que as reconciliações são value-relevant dada a maior associação entre os números contábeis e o preço das ações.

Apesar da terminologia value-relevance surgir em 1993, a operacionalização destes estudos teve origem na década de 60. Por exemplo, o estudo de Ball e Brown (1968, p. 160) utilizou o 
comportamento do preço das ações para avaliar a utilidade da informação contábil. Segundo os autores (1968, p. 160-161)

se [...] os preços dos títulos de fato se ajustam rapidamente às novas informações, então mudanças nos preços dos títulos irão refletir o fluxo de informações ao mercado. Uma mudança dos preços das ações associada à divulgação do resultado forneceria evidências que a informação refletida no resultado é útil ${ }^{25}$.

No entanto, Holthausen e Watts (2001, p. 4) apresentam algumas críticas a este tipo de pesquisa, principalmente, quando voltada para questões de regulação. Nas palavras dos autores estas pesquisas "[...] investigam a relação empírica entre o preço das ações (ou mudanças nos preços) e os números contábeis, com o propósito de avaliar ou fornecer uma base de avaliação do uso, ou do uso proposto destes números de acordo com a norma contábil" ${ }^{\prime 2}$. Segundo os autores, não há uma teoria que fundamente este tipo de pesquisa e “[...] sem teorias descritivas para interpretar as associações empíricas, os achados da literatura de value-relevance têm implicação ou utilidade limitada para os reguladores"27.

Em resposta às criticas, Barth, Beaver e Landsman (2001) afirmam que, embora não exista nenhuma teoria da contabilidade ou de regulação voltada para o cenário contábil, os agentes reguladores se fundamentam na estrutura conceitual para a elaboração e apresentação das demonstrações contábeis. Os autores explicam que a pesquisa de value-relevance tem por objetivo operacionalizar aspectos importantes da estrutura conceitual tal como relevância por meio dos modelos de valuation.

De acordo com Barth, Beaver e Landsman (2001) o conteúdo informacional da contabilidade pode ser avaliado por meio de estudos de value-relevance, cujo objetivo é analisar a relevância da informação contábil para os investidores. Eles citam que o interesse em observar relevância deve-se pela presença deste conceito na Conceptual Framework do FASB. Portanto, os testes de value-relevance representam uma abordagem para

\footnotetext{
${ }^{25}$ Tradução livre de: "if [...] security prices do in fact adjust rapidly to new information as it become available, then changes in securities prices will reflect the flow of information to the market. An observed revision of stock prices associated with the release of the income report would thus provide evidence that the information reflect in income numbers is useful".

${ }^{26}$ Tradução livre de: "investigate the empirical relation between stock market values (or changes in values) and particular accounting numbers for the purpose of assessing or providing a basis of assessing those numbers' use or proposed use in an accounting standard".

${ }^{27}$ Tradução livre de: "without descriptive theories to interpret the empirical associations, the value-relevance literature's associations have limited implications or inferences for standard setting".
} 
operacionalizar os critérios definidos pelo FASB. Uma maneira de verificar e operacionalizar estas características da informação é por meio do estudo da relação entre os números contábeis e o preço das ações. Assim, um número contábil será value-relevant, ou seja, terá uma relação significante com o preço das ações, apenas se refletir informação relevante para investidores na avaliação de empresas. Diversos modelos de avaliação são usados neste tipo de estudo, geralmente pautados no valor de mercado do patrimônio para avaliar como determinada informação contábil reflete-se na tomada de decisão dos investidores.

Os autores Lopes e Martins (2005, p. 60) ainda comentam que

[...] a relevância dos números contábeis é investigada, dentro da perspectiva da informação, por intermédio do impacto da contabilidade nos preços das ações negociadas em mercados de capitais. Assim, por relevante entende-se a relação entre a informação contábil e os preços negociados, que é passível de investigação por intermédio de modelos estatísticos e econométricos.

Estes modelos estatísticos e econométricos já foram aplicados em diversas pesquisas, caracterizando uma estratégia de investigação científica. Segundo Bunge (1980, p. 34), as estratégias de investigação se baseiam em "[...] diversas táticas ou métodos especiais característicos das ciências e tecnologias particulares", porém o autor ressalta que "[...] nenhuma dessas táticas é exaustiva e infalível". O resultado bem sucedido é fruto do método utilizado, da escolha do problema, dos meios (conceituais e empíricos) disponíveis e, não menos importante, do talento do pesquisador. Bunge (2004) ainda comenta sobre as dificuldades ao mensurar atributos de natureza qualitativa, sendo que o principal desafio está no embasamento teórico do conceito estudado.

Apesar disso, muitos estudos têm investigado o conteúdo informacional da contabilidade, pautados pelas considerações feitas por Barth, Beaver e Landsman (2001). No Brasil, Lopes (2001) pode ser considerado um trabalho pioneiro que investiga o conteúdo informacional da contabilidade em mercado de ações. As hipóteses de pesquisa são: i) a avaliação baseada em resultados contábeis futuros é tão relevante quanto aquela baseada em dividendos futuros; ii) preços correntes podem ser explicados por variáveis contábeis (resultado e patrimônio) com coeficientes estatisticamente significantes; e iii) o resultado contábil incorpora significativamente o resultado econômico. A estrutura geral do trabalho está fundamentada no modelo de avaliação de Ohlson (1995), sendo que as hipóteses foram testadas a partir de modelos de regressão entre preços de ações e variáveis contábeis. Segundo Lopes (2001, p. 
14), a escolha do "modelo de Ohlson (1995), deve-se principalmente à fundamentação teórica deste que fornece o arcabouço suficiente para que a contabilidade possa ser integrada em uma função de avaliação do valor da empresa". Portanto, o modelo de Ohlson forneceu uma fundamentação teórica necessária para que os estudos empíricos pudessem ser aplicados. Entre os principais achados, pode-se citar a observação de poder explicativo semelhante para os modelos de avaliação baseados em informações contábeis e dividendos. No que diz respeito à capacidade dos números contábeis em explicar os preços correntes, encontrou-se grande poder explicativo para o patrimônio líquido e não para o resultado. Este resultado pode ser explicado pelo modelo societário brasileiro que proporciona maior importância aos dados do balanço para fins judiciais. E, por último, o autor verificou que o resultado contábil não reconhece significativamente o comportamento do resultado econômico, conforme expectativa a partir do modelo de governança corporativa.

\subsubsection{Modelos de relevância e tempestividade: fundamentação, evidências empíricas e problemas econométricos}

Os modelos normalmente usados para investigar a relevância da informação contábil são dois: i) retorno das ações como variável dependente; e ii) preço das ações como variável dependente. Em vista disso, Kothari e Zimmerman (1995) apresentam uma discussão sobre qual seria o modelo mais adequado a ser usado pelos pesquisadores, pois enquanto alguns autores descrevem as duas abordagens como complementares, outros afirmam que o modelo baseado no retorno possui menos problemas econométricos.

Uma análise inicial dos autores constata que os dois modelos, retorno e preço, se apoiam na premissa de que o resultado corrente contém informação sobre a expectativa de fluxo de caixa futuro, ou seja, o resultado do período é uma proxy para a expectativa do mercado. No entanto, o resultado é formado por dois componentes, um que reflete uma surpresa para o mercado, e o outro que é antecipado pelo mercado, por exemplo, por meio de previsão de analistas. Segundo Kothari e Zimmerman (1995, p. 156)

[...] no modelo retorno, o componente antecipado é irrelevante na explicação do retorno corrente e, portanto, representa um erro na variável independente, viesando o coeficiente angular do resultado em direção a zero. Ao contrário, o preço da ação corrente no modelo preço reflete o efeito acumulado da informação contida no resultado e, portanto, varia devido aos dois componentes. Assim, não há viés nas variáveis do modelo preço. Intuitivamente, o resultado corrente não é correlacionado 
com o resultado futuro, que é incorporado no preço corrente das ações - a variável dependente. Portanto, econometricamente, o modelo preço tem uma variável omitida não correlacionada, o que reduz o poder explicativo, porém o coeficiente angular estimado é não viesado ${ }^{28}$.

Uma maneira de explicar estas diferenças deve-se ao aspecto temporal. O retorno é calculado para um período específico, por isso, ao considerar os dois componentes do resultado (antecipado e surpresa) para explicar o comportamento do retorno, espera-se que, apenas o componente surpresa seja importante para explicar as variações de retorno das ações, pois o efeito antecipado já afetou o retorno. Por outro lado, o preço da ação reflete informações públicas e privadas, passadas e correntes, pelo menos em mercados eficientes, portanto, considera-se os dois componentes do resultado.

Este aspecto, na visão de Kothari e Zimmerman (1995), ajuda a explicar o viés nas variáveis independentes para lucro ou prejuízo contábil, que está presente apenas no modelo de retorno. Em contrapartida, o modelo preço não contempla uma variável representativa do resultado contábil futuro, que pode ser uma variável relevante para explicar as variações no preço da ação. Sendo assim, devido à baixa persistência do resultado (SLOAN, 1996), espera-se que não haja uma correlação entre os resultados corrente e futuro, resultando em uma variável omitida não correlacionada, além de um baixo poder explicativo. Deve-se ressaltar que alguns problemas econométrico do modelo baseado no preço podem ser superados ao usar primeiras diferenças (CHRISTIE, 1987). Além disso, as limitações dos modelos podem ser superadas por meio da correção de White (1980).

Ainda no contexto dos modelos, o estudo de Easton (1999) apresenta uma ligação interessante. Em contraposição ao modelo baseado no retorno, Easton (1999, p. 401) tece algumas considerações para o modelo baseado no preço.

Em qualquer ponto do tempo, o preço reflete todos os retornos (isto é, mudanças no valor de mercado) desde o início da existência da empresa, enquanto o patrimônio

\footnotetext{
${ }^{28}$ Tradução livre de: "Current earnings, however, reflect both a surprise to the market and a "staid" component that the market had anticipated in an earlier period. In the return model, the stale component is irrelevant in explaining current return and thus constitutes an error in the independent variable, biasing the slope coefficient on earnings toward zero (e.g., Brown, Griffin, Hagerman, and Zmijewski, 1987). By contrast, the current stock price in the price model reflects the cumulative effect of earnings information, and thus varies due to bosh the surprise and stale components. Therefore, there is no errors-in-variables bias in price-model regressions. Intuitively, current earnings are uncorrelated with the information about future earnings contained in the current stock price, the dependent variable. Econometrically, the price model thus has an uncorrelated omitted variable, which reduces explanatory power, but the estimated slope coefficient is unbiased (Maddala, 1990)".
} 
líquido representa todas as mudanças no valor (lucros ou prejuízos) durante este período. O patrimônio líquido irá refletir o efeito acumulado da defasagem da divulgação contábil - alguns dos eventos relevantes observados pelo mercado (e, portanto, capturados pelos retornos) em anos anteriores serão incluídos no resultado de períodos posteriores, mas alguns permanecerão não registrados no patrimônio líquido. $\mathrm{O}$ efeito desta defasagem da divulgação contábil nas regressões baseadas no preço é similar àquele do modelo baseado no retorno $[\ldots]^{29}$.

Para visualizar de maneira mais clara a relação entre as variáveis contábeis e de mercado, Easton (1999) apresenta um simples modelo, que considera o patrimônio líquido como base para determinação do valor de mercado da empresa. Portanto, assume-se que o valor contábil por ação da empresa $j$ no período $t\left(B_{j t}\right)$ equivale ao seu valor de mercado por ação $\left(P_{j t}\right)$.

$$
P_{j t}=B_{j t}
$$

\section{Equação 1}

O segundo passo corresponde a considerar a relação entre valor de mercado por ação e resultado por ação. Se os resultados da empresa $i$ para o período $t$ podem ser tratados como uma perpetuidade, e estes resultados forem pagos na forma de dividendos no período que ocorrem, então, o preço por ação com os dividendos $\left(P_{i t}+d_{i t}\right)$ é um múltiplo dos resultados por ação $\left(X_{i t}\right)$.

$$
P_{i t}+d_{i t}=\left(1+r_{i}^{-1}\right) X_{i t}
$$

Equação 2

onde $r$ é a taxa de retorno esperada para as ações da empresa $i$.

O terceiro passo fundamenta-se na consideração de seguinte premissa: assumi-se que a proporção $k$ de ativos da empresa, como os ativos intangíveis não reconhecidos nas demonstrações contábeis, pode ser avaliada por meio da equação 2 , enquanto a outra parte (1k) dos ativos da empresa, tais como ativo imobilizado, pode ser avaliada por meio da equação 1.

\footnotetext{
${ }^{29}$ Tradução livre de: "At any point in time, price reflects all returns (that is, changes in market value) since the firm came into existence, while book value represents all accounting measures of changes in value (earnings) during the period. Book value will reflect the cumulative effect of accounting reporting lag - some of the valuerelevant events observed by the market (and therefore captured in returns) in early years will be included in accounting earnings of later years, but some will remain unrecovered in book value. The effect of this accounting reporting lag in the price-levels regression is similar to the effect in the returns regression [...]".
} 


$$
P_{n t}=(1-k) B_{n t}+k\left[\left(1+r_{n}^{-1}\right) X_{n t}-d_{n t}\right]
$$

Equação 3

Ohlson (1995) fornece uma fundamentação para esta equação em um ambiente de incerteza dinâmica, que baseia-se na premissa de lucro limpo e nas proposições de Miller e Modigliani (1961). Nesta abordagem, as outras variáveis que influenciam o valor da empresa são capturas pelo termo $v_{n t}$ :

$$
P_{n t}=(1-k) B_{n t}+k\left[\left(1+r_{n}^{-1}\right) X_{n t}-d_{n t}\right]+\alpha v_{n t}
$$

Equação 4

Assim, o trabalho de Ohlson (1995) pode ser usado como base teórica para muitos estudos que investigam a relação entre preço, patrimônio líquido e lucro. Estes estudos são baseados nas variações da seguinte regressão linear:

$$
P_{n t}=\alpha_{0}+\alpha_{1} B_{n t}+\alpha_{2} X_{n t}+\varepsilon_{n t}
$$

Equação 5

onde $\alpha_{1}, \alpha_{2} e \alpha_{3}$ são os parâmetros gerados pela regressão.

O modelo de Ohlson (1995) permite que esta abordagem encontre uma base teórica para interpretação das estimativas dos coeficientes gerados pela regressão, neste caso $\alpha_{0}, \alpha_{1}$ e $\alpha_{2}$. A partir disto, Easton (1999) faz três considerações: i) o modelo atende a um papel de avaliação para outras informações e dividendos, sendo que um intercepto diferente de zero sugere que o poder explicativo incremental de patrimônio líquido e resultado, em média, é diferente de zero; ii) o coeficiente gerado para a variável patrimônio líquido é negativamente relacionado à persistência nos resultados anormais, portanto, um elevado coeficiente para patrimônio implica em baixa persistência para os resultados; iii) o coeficiente para a variável resultado tem uma relação positiva com sua persistência e negativa com a taxa de retorno esperada.

A fundamentação teórica proporcionada pelo modelo de Ohlson (1995) também pode ser usada para regressão com base no retorno. Ao tomar a primeira diferença da equação 5, 
assumir a premissa de lucro limpo, dividi-la pelo preço do período inicial e rearranjar alguns termos, tem-se:

$$
r e t_{n t}=(1-k)\left[X_{n t} / P_{n t-1}\right]+k\left(1+r_{n}^{-1}\right)\left[\Delta X_{n t} / P_{n t-1}\right]+k\left[d_{n t-1} / P_{n t-1}\right]+\alpha \Delta v_{n t}
$$

Equação 6

onde $r e t_{n t}$ é a taxa de retorno sobre o investimento na empresa $n$ para o período fiscal $t-1$ a $t$. Esta equação pode ser vista com uma base teórica para a seguinte equação.

$$
r e t_{n t}=\beta_{0}+\beta_{1}\left[X_{n t} / P_{n t-1}\right]+\beta_{2}\left[\Delta X_{n t} / P_{n t-1}\right]+\mu_{n t}
$$

Equação 7

Ambas as equações, 5 e 7, possuem a mesma base teórica, portanto, Easton (1999) afirma que a teoria prevê: $\alpha_{0}=\beta_{0}=0, \alpha_{1}=\beta_{1}$ e $\alpha_{2}=\beta_{2}$, o que implica em duas questões:

- Há alguma questão que pode ser tratada pelo modelo de preço, mas não solucionada pelo modelo de retorno?

- Considerando que os resultados estimados pelos dois modelos são diferentes, qual modelo é mais bem especificado?

Em virtude destas questões, Easton (1999, p. 399) faz uma análise comparativa entre os dois modelos e apresenta algumas considerações. Na primeira, conclui-se que, os estudos usando retorno das ações para avaliar a relevância da contabilidade, fornecem evidência empírica restrita ao período no qual as demonstrações contábeis foram divulgadas, ou seja, o período de análise. Sendo assim, os estudos que investigam a resposta do mercado durante um curto espaço de tempo, buscam avaliar o papel dos dados contábeis em fornecer informação que afeta a percepção dos investidores, a respeito de eventos que alteram o valor da empresa.

A segunda conclusão resume-se na apresentação de argumentos favoráveis à utilização do modelo baseado no retorno: i) os modelos teóricos que fundamentam o uso de preço das ações como métrica também fornecem uma base teórica para modelos que usam a taxa de retorno como métrica de mercado; ii) as regressões de retorno podem ser usadas como base para testes de hipóteses sobre timeliness ou tempestividade em relatar mudanças no valor a partir 
das demonstrações contábeis; iii) as regressões que usam preço como variável dependente apresentam problemas de escala. A terceira conclusão diz respeito à interpretação de gráficos de dispersão entre retorno e resultado, os quais mostram uma relação não linear entre retorno e resultado.

Portanto, coerente com a literatura, normalmente os modelos baseados em preços são usados para avaliar a relevância da informação contábil, enquanto os modelos de retorno são aplicados para analisar a tempestividade.

\subsection{O Modelo de Ohlson}

O objetivo desta seção é descrever as principais características do Modelo de Ohlson, ressaltando o seu papel nos estudos voltados para a relevância da informação contábil.

Ohlson (1995) desenvolveu um modelo de avaliação de empresas a partir de resultados, correntes e futuros, patrimônio líquido e dividendos. O autor (1995, p. 663) explica que uma das motivações para sua aplicação fundamenta-se na "[...] ideia de que, alguns eventos relevantes podem influenciar os resultados esperados futuros ao contrário dos resultados correntes, isto é, as medidas contábeis incorporam alguns eventos relevantes apenas após um período" ${ }^{\prime 30}$. Neste trecho, o autor admite que os números contábeis revelam alguma informação útil para fins de avaliação. Com o propósito de esclarecer esta relação, Iudícibus e Lopes (2004) explicam que o modelo representa grande utilidade para a pesquisa empírica produzida pela Teoria Positiva da Contabilidade, pois

[...] sugere uma teoria na qual o valor de mercado do patrimônio líquido de uma entidade é função de variáveis contábeis atuais e futuras, além de incluir outras informações que afetarão os resultados contábeis no futuro. Isso somente é possível, pelo fato de o modelo teórico estabelecer ligação entre o resultado contábil, patrimônio líquido e o valor de mercado da empresa. Esse modelo, por incorporar as variáveis contábeis como as determinantes do valor da empresa, incentivou discussões teóricas e exames empíricos sobre o papel da contabilidade e suas informações no processo de avaliação (IUDÍCIBUS; LOPES, 2004, p. 94).

Os estudos de value-relevance, que são criticados pela ausência de base teórica (HOLTHAUSEN; WATTS, 2001), podem buscar fundamentação no modelo de Ohlson

\footnotetext{
${ }^{30}$ Tradução livre de: "[...] the idea that some value-relevant events may affect future expected earnings as opposed to current earnings, that is, accounting measurements incorporate some value-relevant events only after a time delay".
} 
(1995), o qual pode ser decomposto para que seja possível analisar a relevância dos números contábeis, conforme já demonstrado por Easton (1999) na seção anterior.

No entanto, a aplicação do modelo de Ohlson (1995) requer a observação de algumas premissas. A primeira assume que o valor presente dos dividendos esperados, ou present value of expected dividends - PVED, determine o valor de mercado da empresa.

$$
P_{t}=\sum_{\tau=1}^{\infty} R_{f}^{-\tau} E_{t}\left[d_{t+\tau}\right]
$$

Equação 8

onde $P_{t}$ é o valor de mercado, ou preço, do patrimônio líquido da empresa na data $t ; d_{t}$ é o valor de dividendos pago na data $t$; $R_{f}$ corresponde a taxa livre de risco mais $1 ; E_{t}[$.$] é$ operador do valor esperado condicionado a data $t$.

Nota-se que o modelo de avaliação depende de dados contábeis, considerando a presença do valor presente dos dividendos esperados. As próximas premissas introduzem o resultado do período e o patrimônio líquido.

A segunda premissa admite que os dados contábeis e os dividendos satisfaçam a relação de lucro limpo, ou clean surplus relation, sendo que os dividendos reduzem o patrimônio líquido sem afetar os resultados correntes.

$$
y_{t}-y_{t-1}=x_{t}-d_{t}
$$

\section{Equação 9}

onde $y$ corresponde ao patrimônio líquido; $x$ é o resultado do exercício; e $d$ é o total de dividendos do período.

A terceira premissa prevê um modelo linear que compõe o comportamento temporal dos resultados anormais, sendo que o resultado anormal é obtido pela diferença entre o resultado corrente e uma parcela que representa a remuneração ao custo de capital. 


$$
x_{t}^{a}=x_{t}-\left(r \times y_{t-1}\right)
$$

\section{Equação 10}

onde $x^{a}$ corresponde ao resultado anormal.

Portanto, considerando que PVED e a relação de lucro limpo implicam em valor de mercado igual ao valor contábil do patrimônio líquido mais o valor presente dos resultados anormais esperados, o modelo de avaliação enfatiza a previsão dos resultados anormais ao invés dos dividendos (OHLSON, 1995). Esta relação pode ser deduzida por meio das premissas um e dois.

Isolando $d_{t}$ da segunda premissa, tem-se:

$$
d_{t}=x_{t}-\left(y_{t}-y_{t-1}\right)
$$

Equação 11

Após isso, a substituição da equação 11 na primeira premissa resulta em:

$$
\begin{aligned}
& P_{0}=\sum_{t=0}^{\infty} \frac{x_{t}-\left(y_{t}-y_{t-1}\right)}{(1+r)^{T}} \\
& P_{0}=\sum_{t=0}^{1} \frac{x_{1}-\left(y_{1}-y_{0}\right)}{(1+r)^{1}}+\sum_{t=2}^{\infty} \frac{x_{2}-\left(y_{2}-y_{1}\right)}{(1+r)^{2}}+\ldots \\
& \vdots \\
& P_{0}=y_{0}+\frac{x_{1}^{a}}{(1+r)^{1}}+\frac{y_{1}}{(1+r)^{1}} \\
& P_{0}=y_{0}+\sum_{t=0}^{\infty} \frac{x_{t}^{a}}{(1+r)^{t}}
\end{aligned}
$$

Equação 12

Logo, ao assumir uma taxa de crescimento constante, pode-se apresentar:

$$
P_{0}=y_{0}+\frac{x_{t}^{a}}{r-g}
$$

Equação 13 
Em um trabalho mais recente Ohlson e Juettner-Nauroth (2005) desenvolveram um modelo de avaliação que mostra como o valor da empresa depende dos resultados e de seu crescimento. O princípio central do modelo é que o crescimento nos resultados explica o índice preço/resultados esperados. É importante destacar que o índice preço/resultados esperados pode ser comparado com o índice preço/resultados correntes com a seguinte ideia: se a expectativa é de que o resultado aumente no futuro, então espera-se que o índice preço/resultados esperados seja menor em relação ao índice preço/resultados correntes. Para explicar o índice preço/resultados esperados o modelo considera duas medidas de crescimento de resultado, uma para o curto prazo e outra para o longo prazo. Outra característica é a possibilidade de acomodar diferentes políticas de dividendos, pois o modelo não depende de um parâmetro para o pagamento de dividendos (OHLSON; GAO, 2008).

Após a descrição de premissas os autores apresentam o modelo Abnormal Earnings Growth AEG, que iguala o valor da empresa aos resultados esperados capitalizados, mais um ajuste para o crescimento anormal dos resultados. Além disso, pode-se utilizar de "engenharia reversa", para calcular o custo de capital da empresa em função de valor, resultado e crescimento a curto e longo prazos. Desta forma, pode-se inferir o custo de capital da empresa por meio do preço de sua ação e das projeções dos analistas (OHLSON; GAO, 2008).

$\mathrm{Na}$ mesma linha, Easton (2009) fez uma revisão da literatura sobre custo de capital e apresenta alguns modelos. O autor apresenta o modelo de capitalização de dividendos e, a partir deste, deriva o modelo de avaliação baseado no resultado residual ou residual income valuation model - RIV, os quais são voltados para a avaliação do patrimônio líquido.

Adicionalmente, o autor explica uma peculiaridade do modelo RIV, que implica na validade da taxa de retorno obtida. A emissão de novas ações altera o número de ações em circulação que, por sua vez, pode implicar na ausência de sustentação da premissa do lucro limpo em bases por ação. Em outras palavras, enquanto o patrimônio líquido inicial é dividido por certa quantidade de ações, o patrimônio líquido final pode ser dividido por outra quantidade de ações, desde que haja emissão de novas ações, isto é, altera-se o denominador da relação entre patrimônio e quantidade de ações.

Devido a este e outros pontos, Ohlson (2005) defende o uso do modelo de avaliação baseado no crescimento dos resultados anormais ou abnormal earnings growth - AEG (EASTON, 
2009). Enquanto o RIV fundamenta-se no patrimônio líquido e no resultado residual esperado, o AEG tem como base a capitalização dos resultados futuros e uma expectativa de crescimento destes resultados. Os casos especiais ou específicos do modelo de avaliação baseado no crescimento de resultados anormais ou abnormal growth in earnings valuation model são: i) modelos de avaliação baseado no índice preço-resultado ou price-earnings - PE; ii) e modelo de avaliação baseado no preço-resultado dividido pelo crescimento de curto prazo do resultado, ou ainda, PE ratio divided by short-term earnings growth-PEG.

Easton (2004) sugere uma modificação do índice PEG. Nesta modificação, assume-se que o crescimento anormal esperado do próximo período nos resultados fornece uma estimativa imparcial do crescimento anormal do resultado para os próximos períodos. Após isolar a taxa de retorno esperada tem-se:

$$
r_{E}=\sqrt{\frac{e p s_{2}+r_{E} d p s_{1}-e p s_{1}}{P_{0}}}
$$

Equação 14

Este modelo foi usado por vários autores, entre eles, Francis et al (2005), Hail e Leuz (2006) e Lopes e Alencar (2010).

\subsection{Governança Corporativa no Brasil e sua relação com a Qualidade da Informação Contábil}

O objetivo desta seção é justificar a consideração de aspectos de governança corporativa na análise do conteúdo informacional da contabilidade.

Um aspecto fundamental que influencia a demanda informacional no mercado de capitais é o sistema legal (LA PORTA; LOPES-DE-SILANES; SHLEIFER, 1998). O Brasil é classificado como um país de sistema legal code law de origem francesa, oferecendo baixa proteção aos investidores, além de apresentar um mercado de capitais pouco desenvolvido (LA PORTA et al, 1997). Apesar de apresentar um ambiente institucional fraco (ANDERSON, 1999) e desincentivos para atrair capital externo, a economia brasileira passou por algumas transformações sociais, econômicas e políticas que passaram a mudar o cenário 
nacional, culminando no fortalecimento de práticas de governança corporativa. Algumas são resumidas por Silveira (2004):

- Aprovação da Lei n. 10.303/2001, denominada na época por Nova Lei das S.A., promovendo maior proteção aos acionistas minoritários por meio de várias alterações, por exemplo, o mecanismo de tag along;

- Desenvolvimento dos códigos de governança corporativa pela Comissão de Valores Mobiliários - CVM e Instituto Brasileiro de Governança Corporativa - IBGC, sendo dividido em 6 áreas: propriedade, conselho de administração, gestão, auditoria independente, conselho fiscal e conflito de interesses;

- Criação dos níveis de governança corporativa da BM\&FBOVESPA em 2001, permitindo que as empresas adotassem de forma voluntária as práticas de governança corporativa requeridas pelos Níveis 1, 2 ou Novo Mercado, as quais asseguram maior transparência e diretos para os acionistas minoritários;

- Estabelecimento de novas regras pela Secretaria de Previdência Complementar - SPC para a definição de limites de aplicação de recursos dos fundos de pensão, permitindo um investimento maior em empresas listadas nos níveis de governança corporativa da BM\&FBOVESPA;

- Estabelecimento do "Programa de Incentivo à Adoção de Práticas de Governança Corporativa" pelo BNDES em 2002, com o objetivo de incentivar a adoção de práticas de governança mediante a concessão de financiamentos;

- Inserção da adoção das normas de governança no plano diretor do mercado de capitais em 2002 pelos agentes de mercado, e indicação para abrangência do assunto na avaliação das empresas;

Neste contexto, Silveira (2004) estudou a relação entre mecanismos de governança corporativa e valor de mercado e desempenho das empresas brasileiras de capital aberto no período 1998-2002. Entre os principais achados, o autor identificou que a estrutura de propriedade das empresas influencia a qualidade da governança corporativa, visto que foi observada uma relação negativa entre o excesso de direito de voto em posse do acionista controlador e a qualidade da governança. Além disso, as maiores empresas, as emissoras de ADRs e aquelas com melhor desempenho apresentam melhor governança em relação às demais. 
Uma justificativa para o resultado referente às empresas possuidoras de ADRs deve-se aos requisitos exigidos pela Securities and Exchange Commission - SEC, os quais determinam práticas de governança corporativa. Um trabalho de natureza técnica da KPMG (2009) explorou por meio de um check-list as diferenças de algumas práticas de governança corporativa entre empresas listadas nos níveis de governança corporativa da BM\&FBOVESPA e empresas com ADRs. O check-list é composto por questões relacionadas ao conselho de administração - CA, comitês do CA, conselho fiscal, código de ética e conduta, auditora independente, gestão de riscos, auditoria interna, operações com partes relacionadas, controle acionário, estratégia de investimentos, setor e porte. De uma maneira geral, os achados apontam para um maior atendimento dos itens pesquisados por parte das empresas com ADRs, com forte presença dos Comitês do Conselho de Administração, por exemplo, os Comitês de Auditoria e Remuneração, contando ainda com maior percentual de conselheiros independentes. Além disto, todas as empresas emissoras de ADRs analisadas pelo estudo divulgaram seus Códigos de Ética ou de Conduta, enquanto poucas empresas listadas nos Níveis de Governança da BM\&FBOVESPA o fizeram. Aquelas ainda se destacaram na divulgação de práticas de gerenciamento de risco corporativo, de informações sobre os principais fatores de risco do negócio e do funcionamento de auditoria interna. Os itens referentes ao Conselho de Administração e Fiscal não apresentaram diferenças significativas. No entanto, é importante destacar que as empresas pertencentes aos Níveis 2 e 3 de ADR e aquelas presentes no Novo Mercado - os segmentos mais exigentes em termos de práticas de governança - possuem característica significativamente diferentes, tais como, receita operacional, setor de atuação e controle.

Por sua vez, o estudo de Chong e Lopez-De-Silanes (2007) avalia as práticas de governança corporativa em alguns países da América do Sul. Segundo os autores, houve um aumento na proteção destinada aos acionistas na última década, mas a região ainda oferece uma baixa proteção em relação a outros países. Uma possível explicação para isto deve-se ao baixo grau de proteção e transparência, fatores que impedem a criação de um ambiente no qual os problemas podem ser detectados ou perseguidos. Neste ambiente regulatório fraco, as empresas precisam se adaptar a esta estrutura institucional que implica em desvantagem em termos de habilidade para atrair capital. Em função disto, as companhias podem oferecer um pacote de proteção mais adequado aos seus acionistas, com o objetivo de atrair recursos. Para 
aproximar investidores, as empresas podem oferecer práticas superiores de governança corporativa.

O estudo de Chong e Lopez-De-Silanes (2007) avaliou tais práticas por meio de um questionário enviado às empresas dos países analisados, incluindo o Brasil. A pontuação obtida por meio dos dados do questionário revela que, embora a divulgação das empresas brasileiras seja superior em relação aos outros países, o item "direito dos acionistas" apresentou uma contagem muito baixa, principalmente no que diz respeito às práticas dos conselhos para coibir conflitos de interesses. Este resultado é considerado desfavorável para as companhias brasileiras, pois é associado a uma dificuldade para atrair recursos nacionais ou internacionais, explicando o aumento de entidades ao longo dos últimos anos que se adequaram aos padrões da SEC, com o objetivo de emitir ADRs e suprir a necessidade de capital.

Diante deste cenário de fraca governança corporativa com perspectivas de crescimento pelas empresas brasileiras, Lopes e Walker (2008) investigaram os incentivos que estas companhias possuem para gerar informação contábil de qualidade e adotar voluntariamente práticas superiores de governança corporativa, visando facilitar a obtenção de recursos para realizar os investimentos. Para isto, eles estudaram o efeito de cross-listing a partir da emissão de ADRs, e da adoção de práticas de governança por meio de um índice denominado Brazilian Corporate Governance Index - BCGI. Os autores utilizam uma abordagem de portfólio ou portfolio approach para avaliar as propriedades da informação contábil, que podem ser divididas em: value relevance, timeliness, conservatism e earning management. Os achados revelam que a governança corporativa influencia a qualidade dos números contábeis das empresas brasileiras. Além disto, nota-se que a governança contribui para aumentar a relevância da informação contábil das empresas que não possuem ADRs. Por outro lado, as empresas emitentes de ADRs, possuidoras de uma governança superior, usufruem de um aumento no conservadorismo condicional.

Mais recentemente, Gabriel (2011) encontrou indícios de que, quanto maior o nível de governança, maior a qualidade da informação contábil, indicando uma relação de complementaridade. $\mathrm{O}$ autor concluiu que a qualidade é influenciada pela origem legal, grau de desenvolvimento do mercado de capitais e características específicas da firma. Portanto, a 
adoção de práticas de governança corporativa pode reduzir obstáculos com o propósito de criar oferta de recursos para o financiamento de empresas.

\subsection{Consequências Econômicas da Adoção das IFRS}

O objetivo desta seção é apresentar, em ordem cronológica, os achados de alguns trabalhos nacionais e internacionais, que investigaram as consequências econômicas da adoção das IFRS.

Liu e Liu (2007) investigaram a relevância dos números contábeis em três segmentos do mercado chinês. As ações negociadas publicamente são conhecidas por A-shares e B-shares, sendo que a primeira é de exclusividade de cidadãos chineses e instituições domésticas, enquanto que a segunda é destinada a capital estrangeiro. Além disso, encontram-se as ações H-shares, na Hong Kong Stock Exchange, pertencentes às empresas que divulgam suas demonstrações de acordo com o padrão internacional, IAS, ou Hong Kong GAAP, que é muito próximo ao padrão internacional de contabilidade. Os principais resultados indicam que a informação contábil nos mercados para $B$-shares (IAS) e $H$-shares (IAS ou HK GAAP) é mais relevante em relação ao A-share (Chinese GAAP).

Ao contrário de Liu e Liu (2007) que analisaram apenas um país, Barth, Landsman e Lang (2008) investigaram a qualidade da informação contábil de acordo com as normas internacionais de 21 países, para o período 1994 a 2003. Para avaliar a qualidade da informação contábil, eles observaram gerenciamento de resultados, reconhecimento oportuno de perdas e relevância. Os achados indicam uma redução no gerenciamento de resultados, um reconhecimento de perdas mais oportuno e informações contábeis mais relevantes após a adoção das normas internacionais, em relação às empresas que adotavam apenas o GAAP local.

O trabalho de Daske et al (2008) também considerou diversos países ao estudar os efeitos da adoção obrigatória das IFRS. Com uma amostra de mais de 3.100 empresas, obrigadas a adotar as IFRS, os autores analisaram os efeitos da liquidez de ações, custo de capital próprio e valor; com a expectativa de que, estas variáveis refletissem a mudança da qualidade da

informação contábil. Os achados revelam um significativo aumento de liquidez para as empresas que adotaram as IFRS. Além disso, os autores observaram um suave aumento no 
valor da empresa, medido pela proxy $\mathrm{Q}$ de Tobin, porém não significante estatisticamente. $\mathrm{E}$, por último, o custo de capital estimado aumentou em relação às empresas que não adotaram, sendo que as diferenças foram significantes estatisticamente. A explicação para estes resultados deve-se a uma possível antecipação dos efeitos proporcionados pela adoção das IFRS. Além disso, a transição de GAAP pode provocar dificuldades na realização de previsão dos resultados e, consequentemente, na estimação do custo de capital e na mensuração do valor das empresas.

Christensen, Lee e Walker (2008) investigaram a adoção obrigatória das normas internacionais de contabilidade na Alemanha, com foco em duas características da informação contábil: gerenciamento de resultados e reconhecimento oportuno de perdas. Os achados indicam que a adoção voluntária das IFRS é associada com redução no nível de gerenciamento de resultados e aumento no reconhecimento oportuno de perdas. No entanto, estes benefícios não são observados para as empresas que adotaram de forma compulsória as IFRS, levando os autores a afirmar que, a adoção das normas internacionais não, necessariamente, conduz a informação contábil de elevada qualidade, pelo menos para àquelas empresas que não tem incentivos para adotar.

Na Austrália, Chalmers, Clinch e Godfrey (2008) restringiram a análise da relevância da informação contábil para os ativos intangíveis; os autores compararam a associação entre ativos intangíveis apresentados de acordo com as IFRS e preço das ações, com a associação entre ativos intangíveis apresentados de acordo com o GAAP nacional e preço das ações, com o propósito de avaliar o conteúdo informacional. De maneira geral, os resultados revelam que a informação em IFRS possui maior relevância para goodwill.

Na França, Cormier et al (2009) investigaram os incentivos da administração que influenciam as escolhas a respeito das isenções facultativas ${ }^{31}$ quando da adoção inicial das normas internacionais de contabilidade. Adicionalmente, os autores analisaram a relevância dos ajustes que devem ser reconhecidos na adoção inicial das IFRS. Os achados indicam que, as empresas com aumento no patrimônio líquido devido aos ajustes obrigatórios, são mais propensas a optar por isenções facultativas que revelam impacto negativo no patrimônio na data de transição, revelando indícios do exercício de discricionariedade. Além disso,

\footnotetext{
${ }^{31}$ Para mais informações consulte o CPC 37 (R1) - Adoção Inicial das Normas Internacionais de Contabilidade.
} 
constatou-se que as empresas francesas listadas em mercados não europeus são menos propensas a escolher isenções facultativas com impacto negativo no patrimônio. Os testes de relevância da informação contábil evidenciam que, os ajustes de natureza obrigatória ou opcional no patrimônio líquido são mais relevantes em comparação ao French GAAP, sinalizando um aumento na qualidade das demonstrações contábeis de acordo com as IFRS.

$\mathrm{Na}$ Inglaterra, Horton e Serafeim (2009) investigaram a reação do mercado e a value relevance do conteúdo informacional dos relatórios contábeis obrigatórios exigidos pela IFRS 1. Os autores encontraram retorno anormal negativo significativo para empresas que divulgaram a reconciliação de resultados negativos, permitindo concluir que, esta informação é value relevant, porém apenas após a divulgação. Por outro lado, o conteúdo informacional de ajustes de resultados positivos é value relevant antes da divulgação. Segundo os autores, estes resultados são consistentes com a ideia de que, a administração posterga a comunicação de más notícias até estar em conformidade com IFRS, concluindo que a adoção obrigatória das IFRS altera a crença dos investidores sobre preço das ações. Os achados permitem afirmar que as IFRS revelam informação oportuna e value relevant.

Paananen e Lin (2009) estudaram a qualidade dos números contábeis das empresas alemãs no período 2000-2006. No entanto, com o objetivo de investigar o efeito das normas internacionais, eles separaram este período em três subperíodos: i) 2000-2002, no qual algumas empresas alemãs divulgaram as demonstrações de acordo com as International Accounting Standards (IAS); ii) 2003 e 2004, empresas que divulgaram voluntariamente as demonstrações contábeis segundo as International Financial Reporting Standards (IFRS); e iii) 2005 e 2006, o período no qual as empresas adotaram obrigatoriamente as IFRS. Os achados revelaram uma redução na qualidade da informação contábil para as empresas alemãs após a adoção obrigatórias das IFRS. Os autores observaram que, tanto o resultado líquido quanto o patrimônio líquido, apresentaram indícios de menor relevância durante o período de 2003-2006 em relação ao período 2000-2002. Os resultados para suavização e reconhecimento oportuno de perdas são coerentes com os achados a respeito da relevância da informação contábil.

Em seguida, Lee, Walker e Christensen (2010) buscaram evidências empíricas sobre o custo de capital próprio na Europa após adoção obrigatória das IFRS em 2005. Os autores estimaram o custo de capital próprio pelos modelos AEG e PEG para empresas de 17 países 
europeus de 1995 a 2006. Os achados indicam uma redução no custo de capital próprio em torno de 0,72 para as estimativas baseadas no modelo PEG. Para o modelo AEG, os autores observaram uma redução para os seguintes países: Bélgica, Finlândia, França, Irlanda, Holanda, Portugal, Espanha, Suécia, Suíça e Reino Unido. Ao dividir a amostra de acordo com algumas características institucionais - direitos dos acionistas minoritários, importância do mercado de capitais como fonte financiamento para as empresas, concentração de propriedade, qualidade da divulgação e gerenciamento de resultados - os autores observaram uma redução maior no custo de capital para os países de maior incentivo para divulgar, e com enforcement. Um resultado contrário é observado para os países de menor incentivo para divulgar e baixo enforcement.

Outro estudo sobre custo de capital é realizado por Li (2010), que investigou o impacto da adoção obrigatória de IFRS sobre o custo de capital usando uma abordagem difference-indifference. A autora analisou o período 1995-2006, sendo que a amostra foi composta por empresas da União Europeia, totalizando 6.456 observações empresas-ano. Os achados indicam uma redução no custo de capital próprio para a adoção obrigatória em torno de 47 pontos-base. No entanto, este resultado não pode ser estendido para os países que possuem um ambiente legal de baixo enforcement.

Ainda no cenário europeu, Armstrong et al (2010) examinaram os retornos ajustados pelo mercado em 16 eventos que, segundo os autores, afetam a probabilidade de adoção das IFRS na Europa, de março de 2002 a novembro de 2005. De uma forma geral, os resultados indicam que os investidores reagem positivamente ao observarem eventos que aumentam a probabilidade de adoção das IFRS. Os principais resultados observados são: i) reação positiva para empresas com baixa qualidade de informação na pré-adoção, consistente com a expectativa de que a adoção das normas internacionais resulta em benefício informacional; ii) reação positiva para empresas com alta informação assimétrica no período pré-adoção, o que é consistente com a expectativa de que a adoção das IFRS poderá diminuir esta assimetria; e iii) menor reação positiva para as empresas de países code law. Este último resultado, embora não permita uma definitiva inferência, é consistente com investidores preocupados com a implementação das IFRS em países com baixo poder de enforcement.

Mais um estudo na Austrália é apresentado por Chalmers, Clinch e Godfrey (2011), que investigaram o caso de empresas listadas. Os achados indicam uma mudança na associação 
entre informação contábil e adoção das normas internacionais. A relevância do resultado líquido aumenta quando as empresas passam a adotar as IFRS. No entanto, os autores notaram que esta maior associação surgiu no ano precedente à adoção obrigatória, revelando um interesse por parte da administração em diminuir as diferenças entre as demonstrações contábeis em AGAAP e IFRS nas proximidades da adoção inicial. No caso do patrimônio líquido, apesar de não observar um aumento na relevância, ele permaneceu significante estatisticamente ao longo do período de adoção das IFRS. Além disso, Chalmers, Clinch e Godfrey (2011) encontraram uma maior persistência para o resultado a partir do período de adoção das IFRS. Os autores concluem que os resultados são coerentes com os achados de outras pesquisas, ou seja, em países com forte proteção aos investidores e divulgação de elevada qualidade, a adoção das IFRS afeta a relevância da informação contábil.

Por sua vez, Clarkson et al (2011) investigaram o impacto da adoção obrigatória das IFRS na relevância da informação contábil em diversos países da Europa, além da Austrália, totalizando 15 países. Os achados podem ser resumidos em três partes: i) a adoção das IFRS contribuiu para aumentar o patrimônio líquido e o resultado líquido das empresas, em proporção maior para países code law; ii) as regressões lineares indicam que, após adoção das IFRS, houve um aumento na relevância da informação contábil em países code law, e uma diminuição nos países common law; no entanto, esta redução da relevância não foi observada nos modelos de regressão não linear, sugerindo que a deterioração do poder explicativo no modelo linear para países common law, deve-se a aumentos na não linearidade entre preços das ações e informação contábil; iii) ao analisar os dados agregados dos 15 países da amostra e controlar as não linearidades, os autores concluíram que não houve mudanças na relação entre patrimônio líquido, resultado líquido e preço das ações; ainda na análise do modelo não linear, não houve diferenças nos erros de mensuração entre países de common law e code law após IFRS, sugerindo a mesma qualidade da informação contábil para os dois grupos, o que, por sua vez, contribui para aumentar a comparabilidade das demonstrações contábeis dos países adotantes das IFRS.

Khurana e Michas (2011) apresentam uma abordagem metodológica diferente para avaliar qualidade da informação contábil. Eles investigaram se a adoção obrigatória às IFRS no nível de país reduz o viés de investidores norte-americanos contra investimentos em países estrangeiros. Este viés, segundo os autores, é explicado por uma maior tendência por parte dos investidores em atribuir maior peso às ações de seu país de origem na formação das 
carteiras de ações. A justificativa para tal viés fundamenta-se na dificuldade do investidor norte-americano em avaliar investimentos em países estrangeiros que possuem padrões contábeis diferentes em relação ao US-GAAP, o que se configura em uma desvantagem informacional. Para isso, os autores analisaram 85 países no período 2002-2007. Os resultados indicam que o viés dos investidores norte-americanos caiu após adoção obrigatória das IFRS, após controlar por efeitos fixos dos países. Além disso, eles observaram que a redução do viés é maior para países com: i) grandes diferenças entre IFRS e o GAAP doméstico; ii) regras mais rigorosas e de origem legal common law; e iii) grande incentivo para divulgar informações de alta qualidade.

Na Suécia, Hellman (2011) investigou as empresas que adotaram as IFRS a partir de 2005 de acordo com a Lei 1606/2002 do European Parliament and of the Council. Contundo, o autor revela que não era esperada uma mudança drástica, visto que as empresas suecas já adotavam quase todas as IFRS. Os achados mostram um aumento significante no resultado líquido e nos números do balanço quando da adoção em 2005, justificado pela aplicação de normas - IAS 39, IAS 40 e IAS 41 - anteriormente não incorporadas no processo de convergência gradual em função do interesse em manter o elevado conservadorismo. Além disso, ao restringir a análise de comparação às normas que não sofreram alterações, nota-se uma redução tanto no patrimônio líquido quanto no resultado líquido. Estes resultados mostram que a adoção suave proporcionou aos responsáveis pela elaboração das demonstrações contábeis uma discricionariedade para aumentar e diminuir o resultado líquido, dependendo dos incentivos específicos da empresa. Neste caso, a redução do resultado e patrimônio pode ser uma forma de compensar os aumentos proporcionados pelas novas normas IAS 39, IAS 40 e IAS 41. Contudo, o predomínio de empresas que divulgaram resultado elevado durante o período de adoção suave sugere que os incentivos relacionados aos tributos foram menos importantes em comparação àqueles para aumentar os resultados.

Nos Emirados Árabes Unidos, Alali e Foote (2012) investigaram a relevância da informação contábil a partir da mudança do padrão contábil doméstico para o padrão internacional de contabilidade. Os autores usaram modelos baseados em retorno e preço das ações, sendo que ambos revelam que a informação contábil seguindo as IFRS é relevante nos Emirados Árabes Unidos, um país que exibe alguns atributos associados com um ambiente informacional fraco. Este resultado é acompanhado de transformações no ambiente institucional do país, que atraíram investidores internacionais. 
No cenário nacional, deve-se destacar o trabalho de Lima (2010), que investigou a relevância da informação contábil após promulgação da Lei $n^{\circ} 11.638 / 07$, isto é, na adoção parcial das normas internacionais de contabilidade (IFRS). O autor encontrou os resultados em três perspectivas diferentes. A primeira, de curto prazo, revelou que as empresas com incentivos para divulgar informações de maior qualidade - ADR e Governança Corporativa - não apresentaram diferenças em termos de conteúdo informacional. A segunda perspectiva, uma análise de longo prazo, indicou um aumento na relevância das informações contábeis após adoção parcial das IFRS. Por último, a terceira que investiga os ajustes de reconciliação do resultado e do patrimônio líquido, sugere que ambos são relevantes para o mercado de capitais brasileiro.

\subsection{Quadro resumo das consequências econômicas nos países adotantes das IFRS}

O quadro a seguir apresenta os principais resultados das pesquisas comentadas na seção anterior. 
Quadro 1 - Quadro resumo das principais evidências empíricas decorrentes da adoção das normas internacionais de contabilidade

\begin{tabular}{|c|c|c|c|}
\hline Autor (es) & País adotante IFRS/IAS & Aspectos investigados & Principais resultados \\
\hline Liu e Liu (2007) & China & $\begin{array}{ll}\text { Relevância } & \text { da } \\
\text { informação contábil }\end{array}$ & $\begin{array}{l}\text { A informação contábil de } \\
\text { acordo com as IAS é } \\
\text { mais relevante em relação } \\
\text { ao Chinese GAAP. }\end{array}$ \\
\hline $\begin{array}{l}\text { Meulen, Gaeremynck e } \\
\text { Willekens (2007) }\end{array}$ & Alemanha & $\begin{array}{l}\text { Relevância, } \\
\text { tempestividade, } \\
\text { qualidade dos accruals } \\
\text { segundo Dechow e } \\
\text { Dichev (2002) e análise } \\
\text { de persistência. }\end{array}$ & $\begin{array}{l}\text { Os resultados sugerem } \\
\text { que o mercado não reage } \\
\text { de maneira diferente ao } \\
\text { receber informação em } \\
\text { USGAAP e IFRS. }\end{array}$ \\
\hline $\begin{array}{l}\text { Barth, Landsman e Lang } \\
\text { (2008) }\end{array}$ & Diversos países & $\begin{array}{l}\text { Gerenciamento de } \\
\text { resultados, } \\
\text { reconhecimento oportuno } \\
\text { de perdas e relevância da } \\
\text { informação contábil. }\end{array}$ & $\begin{array}{lr}\text { A adoção das } & \text { normas } \\
\text { internacionais } & \\
\text { proporcionou } & \text { uma } \\
\text { redução } & \text { no } \\
\text { gerenciamento } & \text { de } \\
\text { resultados, } & \text { um } \\
\text { reconhecimento } & \text { de } \\
\text { perdas mais oportuno e } \\
\text { informações contábeis } \\
\text { mais relevantes após a } \\
\text { adoção das normas } \\
\text { internacionais. }\end{array}$ \\
\hline Capkun et al (2008) & Diversos países europeus & $\begin{array}{l}\text { Gerenciamento } \text { de } \\
\text { resultado e relevância da } \\
\text { informação contábil. }\end{array}$ & $\begin{array}{l}\text { Há indícios de } \\
\text { gerenciamento de } \\
\text { resultado na adoção } \\
\text { obrigatória, } \\
\text { principalmente em países } \\
\text { de baixa proteção legal. } \\
\text { Ademais a informação } \\
\text { contábil na figura do } \\
\text { lucro mostra-se relevante. }\end{array}$ \\
\hline Daske et al (2008) & Diversos países & $\begin{array}{l}\text { Liquidez das ações, custo } \\
\text { de capital próprio e valor } \\
\text { da empresa. }\end{array}$ & $\begin{array}{lrr}\text { A adoção obrigatória das } \\
\text { IFRS } & \text { proporcionou } \\
\text { aumento da liquidez, } \\
\text { redução do custo de } \\
\text { capital e aumento no } \\
\text { valor da empresa, estas } \\
\text { duas últimas evidências } \\
\text { no ano anterior à adoção } \\
\text { inicial, possivelmente } \\
\text { devido à antecipação dos } \\
\text { efeitos das normas } \\
\text { internacionais. } \\
\text { entanto, os benefícios } \\
\text { ocorrem apenas em } \\
\text { países com um regime } \\
\text { rigoroso de enforcement e } \\
\text { onde o ambiente } \\
\text { institucional fornece } \\
\text { incentivos para a a } \\
\text { transparência. }\end{array}$ \\
\hline $\begin{array}{lll}\text { Christensen, } & \text { Lee } & \text { e } \\
\text { Walker (2008) } & & \end{array}$ & Alemanha & $\begin{array}{lr}\text { Gerenciamento } & \mathrm{de} \\
\text { resultados } & \mathrm{e} \\
\text { reconhecimento oportuno } \\
\text { de perdas. }\end{array}$ & $\begin{array}{lr}\text { Os autores não } \\
\text { identificaram } \\
\text { aumento na qualidade da } \\
\text { informação contábil para }\end{array}$ \\
\hline
\end{tabular}




\begin{tabular}{|c|c|c|c|}
\hline & & & $\begin{array}{lr}\text { as empresas } & \text { que } \\
\text { adotaram } & \\
\text { obrigatoriamente } & \text { as } \\
\text { IFRS. } & \end{array}$ \\
\hline $\begin{array}{l}\text { Gjerde, } \quad \text { Knivsfla } \\
\text { Saettem (2008) }\end{array}$ & Noruega & $\begin{array}{lc}\text { Relevância } & \text { da } \\
\text { informação contábil. } & \end{array}$ & $\begin{array}{l}\text { Os achados revelam fraca } \\
\text { evidência de relevância } \\
\text { ao analisar os números } \\
\text { em IFRS, mas os ajustes } \\
\text { de reconciliação do } \\
\text { balanço e do resultado } \\
\text { confirmam a hipótese de } \\
\text { relevância. }\end{array}$ \\
\hline $\begin{array}{l}\text { Prather-Kinsey, } \\
\text { Jermakowicz } \\
\text { Vongphanith (2008) }\end{array}$ & Diversos países europeus & $\begin{array}{l}\text { Relevância } \mathrm{da} \\
\text { informação contábil e } \\
\text { custo de capital próprio. }\end{array}$ & $\begin{array}{l}\text { Os autores observaram } \\
\text { um aumento na } \\
\text { relevância da informação } \\
\text { contábil e redução no } \\
\text { custo de capital próprio, } \\
\text { com maiores benefícios } \\
\text { para os países de origem } \\
\text { code law. }\end{array}$ \\
\hline Horton e Serafeim (2009) & Inglaterra & $\begin{array}{lr}\text { Relevância } & \mathrm{e} \\
\text { oportunidade } & \text { da } \\
\text { informação contábil. } & \end{array}$ & $\begin{array}{l}\text { Os autores concluíram } \\
\text { que a adoção obrigatória } \\
\text { das IFRS altera a crença } \\
\text { dos investidores sobre } \\
\text { preço das ações. As } \\
\text { descobertas permitem } \\
\text { afirmar que as IFRS } \\
\text { revelam informação } \\
\text { oportuna e value } \\
\text { relevant. }\end{array}$ \\
\hline Cormier et al (2009) & França & $\begin{array}{ll}\text { Relevância } & \mathrm{da} \\
\text { informação contábil }\end{array}$ & $\begin{array}{l}\text { A informação contábil de } \\
\text { acordo com as IFRS é } \\
\text { mais relevante em relação } \\
\text { ao French GAAP. }\end{array}$ \\
\hline Paananen e Lin (2009) & Alemanha & $\begin{array}{l}\text { Gerenciamento de } \\
\text { resultados, } \\
\text { reconhecimento oportuno } \\
\text { de perdas e relevância da } \\
\text { informação contábil. }\end{array}$ & $\begin{array}{l}\text { Houve uma redução da } \\
\text { qualidade da informação } \\
\text { contábil em IFRS } \\
\text { confirmada pela análise } \\
\text { de relevância, suavização } \\
\text { e reconhecimento } \\
\text { oportuno de perdas. }\end{array}$ \\
\hline $\begin{array}{lcc}\text { Lee }, & \text { Walker } & \text { e } \\
\text { Christensen (2010) } & \end{array}$ & Diversos países europeus & Custo de capital próprio & $\begin{array}{l}\text { Observa-se uma redução } \\
\text { no custo de capital } \\
\text { próprio, porém maior } \\
\text { para países com maior } \\
\text { incentivo para divulgar e } \\
\text { enforcement. }\end{array}$ \\
\hline Armstrong et al (2010) & Diversos países europeus & $\begin{array}{lr}\text { Percepção } & \text { dos } \\
\text { investidores por meio de } & \text { estudo de evento, } \\
\text { considerando notícias } \\
\text { relacionadas às IFRS. }\end{array}$ & $\begin{array}{l}\text { Os investidores reagem } \\
\text { positivamente } \\
\text { observarem eventos que } \\
\text { aumentam a } \\
\text { probabilidade de adoção } \\
\text { das IFRS. No entanto, } \\
\text { observa-se uma menor } \\
\text { reação positiva para as } \\
\text { empresas de países de } \\
\text { code law, revelando uma } \\
\text { preocupação por parte } \\
\text { dos investidores com a } \\
\text { implementação das IFRS }\end{array}$ \\
\hline
\end{tabular}




\begin{tabular}{|c|c|c|c|}
\hline & & & $\begin{array}{l}\text { em países com baixo } \\
\text { poder de enforcement. }\end{array}$ \\
\hline $\begin{array}{l}\text { Devalle, Onali } \quad \text { e } \\
\text { Magarini (2010) }\end{array}$ & Diversos países europeus & $\begin{array}{ll}\text { Relevância } & \text { da } \\
\text { informação contábil. }\end{array}$ & $\begin{array}{l}\text { Os autores encontraram } \\
\text { evidências de aumento da } \\
\text { relevância, com destaque } \\
\text { para o lucro. }\end{array}$ \\
\hline Kvaal e Nobes (2010) & $\begin{array}{l}\text { Austrália, França, } \\
\text { Alemanha, Espanha e } \\
\text { Reino Unido. }\end{array}$ & Comparabilidade. & $\begin{array}{l}\text { As IFRS permitem } \\
\text { subjetividade, } \\
\text { contribuindo para } \\
\text { diferenças sistemáticas } \\
\text { entre os países estudados, } \\
\text { portanto, reduzindo a } \\
\text { comparabilidade. }\end{array}$ \\
\hline Li (2010) & União Europeia & Custo de capital próprio & $\begin{array}{l}\text { Os achados indicam uma } \\
\text { redução no custo de } \\
\text { capital próprio para a } \\
\text { adoção } \\
\text { exceto para os países que } \\
\text { possuem um ambiente } \\
\text { legal de } \\
\text { enforcement. }\end{array}$ \\
\hline Lima (2010) & Brasil & $\begin{array}{lr}\text { Relevância } & \mathrm{e} \\
\text { oportunidade } & \mathrm{da} \\
\text { informação contábil } & \end{array}$ & $\begin{array}{l}\text { O autor observou um } \\
\text { aumento na relevância } \\
\text { das } \\
\text { confábeis após adoçã̃õo } \\
\text { parcial das IFRS. }\end{array}$ \\
\hline Lima (2011) & Brasil & $\begin{array}{l}\text { Custo de capital próprio e } \\
\text { Liquidez de ações }\end{array}$ & $\begin{array}{l}\text { Os achados revelam } \\
\text { fracos indícios de } \\
\text { redução do custo de } \\
\text { capital, devido a possível } \\
\text { influência da Crise } \\
\text { Financeira de } 2008 \text { e } \\
\text { outros incentivos. } \\
\text { Ademais, a liquidez é } \\
\text { influenciada } \\
\text { positivamente. }\end{array}$ \\
\hline Hellman (2011) & Suécia & $\begin{array}{l}\text { Índice } \\
\text { Comparabilidade } \\
\text { desenvolvido por Gray } \\
(1980)\end{array}$ & $\begin{array}{l}\text { A adoção suave, de forma } \\
\text { gradual e harmonizável, } \\
\text { revela uma } \\
\text { discricionariedade para } \\
\text { aumentar ou diminuir o } \\
\text { resultado líquido, } \\
\text { dependendo dos } \\
\text { incentivos específicos da } \\
\text { empresa. }\end{array}$ \\
\hline Khurana e Michas (2011) & Diversos países & $\begin{array}{l}\text { Viés dos investidores } \\
\text { norte-americanos, } \\
\text { explicado por uma } \\
\text { tendência em atribuir } \\
\text { maior peso às ações de } \\
\text { seu país de origem na } \\
\text { formação das carteiras de } \\
\text { ações }\end{array}$ & $\begin{array}{l}\text { Os resultados indicam } \\
\text { que o viés dos } \\
\text { investidores } \\
\text { americanos caiu norte- } \\
\text { adoção obrigatória das } \\
\text { IFRS, principalmente } \\
\text { para países com regras } \\
\text { mais rigorosas e de } \\
\text { origem legal common } \\
\text { law. }\end{array}$ \\
\hline Clarkson et al (2011) & $\begin{array}{l}\text { Austrália e diversos } \\
\text { países da Europa. }\end{array}$ & $\begin{array}{l}\text { Relevância } \\
\text { informação contábil por } \\
\text { meio da abordagem de } \\
\text { Hung e Subramanyam } \\
(2007) \text {. }\end{array}$ & $\begin{array}{l}\text { Os achados seguindo } \\
\text { modelos lineares revelam } \\
\text { aumento da relevância } \\
\text { para países code law e } \\
\text { redução para países }\end{array}$ \\
\hline
\end{tabular}




\begin{tabular}{|c|c|c|c|}
\hline & & & $\begin{array}{l}\text { common law, os quais } \\
\text { não são suportados pelos } \\
\text { modelos não lineares. } \\
\text { Além disso, os autores } \\
\text { apresentam evidências de } \\
\text { aumento da } \\
\text { comparabilidade. }\end{array}$ \\
\hline $\begin{array}{l}\text { Chalmers, Clinch } \\
\text { Godfrey }(2011)\end{array}$ & Austrália & $\begin{array}{ll}\text { Relevância } & \text { da } \\
\text { informação contábil. } & \end{array}$ & $\begin{array}{l}\text { A informação contábil } \\
\text { tornou-se mais relevante } \\
\text { a partir do período de } \\
\text { adoção das IFRS. }\end{array}$ \\
\hline Alali e Foote (2012) & Emirados Árabes Unidos & $\begin{array}{ll}\text { Relevância } & \text { da } \\
\text { informação contábil. } & \end{array}$ & $\begin{array}{l}\text { A informação contábil } \\
\text { seguindo as IFRS é } \\
\text { relevante nos Emirados } \\
\text { Árabes Unidos, um país } \\
\text { que exibe alguns } \\
\text { atributos associados com } \\
\text { um ambiente } \\
\text { informacional fraco. }\end{array}$ \\
\hline $\begin{array}{ll}\text { Horton, } & \text { Serafeim } \\
\text { Serafeim }(2012) & \text { e }\end{array}$ & Diversos países & $\begin{array}{l}\text { Acurácia das previsões } \\
\text { dos analistas. }\end{array}$ & $\begin{array}{l}\text { Os achados indicam que } \\
\text { após a adoção obrigatória } \\
\text { das IFRS houve um } \\
\text { aumento na acurácia das } \\
\text { previsões dos analistas } \\
\text { em função da maior } \\
\text { comparabilidade a e } \\
\text { qualidade do ambiente } \\
\text { informacional. }\end{array}$ \\
\hline Barth et al (2012) & $\begin{array}{lrr}\text { Estados } & \text { Unidos } & \mathrm{e} \\
\text { diversos } & \text { países } & \text { que } \\
\text { adotam IFRS } & \end{array}$ & Comparabilidade & $\begin{array}{lr}\text { Os autores concluem que } \\
\text { a adoção das IFRS tem } \\
\text { aumentado } \\
\text { comparabilidade dos } \\
\text { números contábeis. }\end{array}$ \\
\hline
\end{tabular}

Entre os diversos trabalhos apresentados no quadro 1, encontram-se evidências empíricas favoráveis às consequências econômicas previstas nas hipóteses desta tese, enquanto outras não. As diferenças podem ser explicadas pelos aspectos institucionais dos países, explorados na seção 2.5 . 


\section{MÉTODO DA PESQUISA}

Este capítulo apresenta a estratégia de pesquisa usada para abordar e analisar os dados empíricos no contexto da adoção completa das IFRS. Para isso, os modelos usados para observar a qualidade da informação contábil e custo de capital próprio são descritos, com destaque para os resultados esperados após adoção completa das IFRS. No entanto, antes de apresentar os modelos faz-se necessário descrever a amostra da pesquisa.

\subsection{Seleção da Amostra e Coleta dos Dados}

A presença de ações de baixa liquidez pode representar um problema nas pesquisas que utilizam alguma medida de valor de mercado como variável dependente. Segundo Lopes e Alencar (2010), o problema ocorre devido aos erros de mensuração nas variáveis, proporcionando um baixo $R^{2}$. Acredita-se que, esse erro na variável dependente seja estatisticamente independente de cada variável explicativa, gerando estimadores consistentes e não viesados, porém com uma variância elevada (WOOLDRIDGE, 2002).

Para evitar este problema, a seleção das empresas da amostra nesta tese baseia-se na carteira teórica do IBrX-100 de 25/06/2011, composta por 100 ações selecionadas entre as mais negociadas na BM\&FBOVESPA ${ }^{32}$, além do conjunto de 30 empresas que adotaram as IFRS antecipadamente. Neste sentido, a amostra é não probabilística, implicando na impossibilidade de generalizar os resultados para a população (MARTINS; THEÓPHILO, 2009). O critério para definir se a empresa divulgou antecipadamente baseia-se na deliberação $\mathrm{CVM} \mathrm{n}^{\circ}$ 603, que exigiu a divulgação dos relatórios trimestrais de 2010 juntamente com as demonstrações contábeis do exercício social de 2010. Portanto, as companhias que divulgaram suas demonstrações contábeis full IFRS, antes de 31/12/2010, foram consideradas no grupo de empresas que adotaram antecipadamente, ou voluntárias (VOL). Logo, as demais foram classificadas no grupo obrigatórias (OBR).

Em seguida, as empresas financeiras e seguradoras, de acordo com a classificação do Economatica, foram eliminadas da amostra, pois elas possuem características que prejudicam

\footnotetext{
${ }^{32}$ Para mais informações sobre os critérios de seleção das ações, pode-se acessar a metodologia completa do IBrX em <http://www.bmfbovespa.com.br/Indices/download/IBrX.pdf>. Acesso em 25 de jun. 2011.
} 
a comparabilidade, tal como elevada alavancagem, além da ausência de alguns dados para aplicação dos modelos ${ }^{33}$. Na determinação da amostra final, outros ajustes foram aplicados, os quais podem ser observados a seguir.

Tabela 3 - Procedimentos para seleção da amostra final

Ações do IBrX-100 de 25/06/2011

(+) Empresas que adotaram antecipadamente as IFRS (VOL)

(=) Subtotal 1

(-) Empresas repetidas, ou seja, que aparecem na carteira IBrX e no grupo VOL

(=) Subtotal 2

(-) Ação de baixa liquidez para o caso de 2 ações da mesma empresa na carteira IBrX

(=) Subtotal 3

(-) Empresas do setor Finanças e Seguros

(=) Quantidade de empresas que compõem a amostra final

100

$\underline{30}$

130

$\underline{(15)}$

115

$\underline{(12)}$

103

$\underline{(10)}$

93

Nota: O critério para definir se a empresa divulgou antecipadamente em IFRS fundamenta-se na deliberação $\mathrm{CVM} \mathrm{n}^{\circ}$ 603. Assim, todas as empresas que divulgaram as demonstrações contábeis full IFRS antes de 31/12/2010 foram consideradas no grupo VOL.

Ainda pode-se observar a quantidade de empresas por setor na tabela 4.

Tabela 4 - Número de empresas por setor

\begin{tabular}{lcc}
\hline Setor & Frequência & \% \\
\hline Alimentos e Beb & 6 & $6 \%$ \\
Comércio & 5 & $5 \%$ \\
Construção & 7 & $8 \%$ \\
Eletroeletrônicos & 1 & $1 \%$ \\
Energia Elétrica & 12 & $13 \%$ \\
Máquinas Indust & 2 & $2 \%$ \\
Mineração & 2 & $2 \%$ \\
Outros & 19 & $20 \%$ \\
Papel e Celulose & 3 & $3 \%$ \\
Petróleo e Gás & 3 & $3 \%$ \\
Química & 3 & $3 \%$ \\
Siderur \& Metalur & 7 & $8 \%$ \\
Software e Dados & 3 & $3 \%$ \\
Telecomunicações & 6 & $6 \%$ \\
Têxtil & 4 & $4 \%$ \\
Transporte Serviç & 6 & $6 \%$ \\
Veículos e peças & 4 & $4 \%$ \\
\hline Total & 93 & $100 \%$ \\
\hline
\end{tabular}

A classificação de setores foi feita com base no Economatica. Além disso, pode-se visualizar no apêndice, as empresas e seus respectivos períodos de adoção das IFRS, as datas de divulgação das demonstrações contábeis e os códigos de negociação na BM\&FBOVESPA.

\footnotetext{
${ }^{33}$ Alguns modelos de gerenciamento de resultado exigem o saldo de contas a receber e estoque.
} 
Os dados para o período 2000-2011 foram coletados nas seguintes bases: Economatica, Data Stream da Thomson, sites da CVM e da NYSE ${ }^{34}$. Na Thomson, as estimativas de lucro por ação foram obtidas para cada fiscal year a partir do período de análise. As demonstrações contábeis consolidadas e suas respectivas datas de divulgação foram coletadas no site da CVM, com destaque para os ajustes de conciliação para lucro líquido e patrimônio líquido exigidos pelo CPC 37 de adoção inicial. Ademais, as empresas emissoras de ADR foram definidas a partir do site da NYSE. Por último, os dados obtidos no Economatica foram:

- Preço das ações em bases diárias, ajustado por proventos;

- Quantidade de ações emitidas;

- Disponível;

- Contas a receber de curto prazo;

- Estoque;

- Despesa Antecipada;

- Ativo circulante;

- Imobilizado;

- Ativo total;

- Passivo circulante;

- Financiamento de curto prazo;

- Dívida total bruta;

- Patrimônio líquido;

- Receita líquida;

- Custo do produto vendido;

- Despesa de venda;

- Despesa administrativa;

- Despesa de depreciação e amortização;

- Outras receitas e despesas;

- Lucro líquido;

- Earnings before interest and taxes - EBIT, ou lucro antes de juros e impostos LAJIR.

\footnotetext{
${ }^{34}$ CVM: <www.cvm.gov.br>; NYSE: <https://nyse.nyx.com/>.
} 
Estes e os outros dados foram usados para o cálculo das variáveis descritas nas seções seguintes.

\subsection{Especificação do Modelo de Diferenças em Diferenças para Custo de Capital}

As empresas foram divididas em dois grupos: empresas que adotaram voluntariamente as normas internacionais (VOL) e aquelas que adotaram de maneira obrigatória (OBR). Essa separação é necessária para aplicar a abordagem de diferenças em diferenças, técnica econométrica utilizada para observar o efeito das IFRS no custo de capital próprio (LI; 2010).

Na contabilidade, os pesquisadores costumam usar este método para investigar mudanças na legislação sobre alguma variável de interesse. Uma vantagem em relação a este método é a possibilidade de separar o efeito da legislação específica de todos os outros desenvolvimentos que ocorrem em torno do período de transição. Consequentemente, pode-se fortalecer as inferências causais (LARCKER; RUSTICUS, 2010).

Segundo Soderstrom e Sun (2007), o problema das variáveis omitidas geralmente está presente nos estudos que investigam a convergência às IFRS entre países. Os mecanismos de precificação e o ambiente informacional, incluindo cobertura dos analistas e a divulgação de informação não financeira, diferem entre os países. Portanto, a comparação de demonstrações contábeis para o mesmo país é uma opção mais adequada e, consequentemente, reduz o problema das variáveis omitidas. Assim, ao trabalhar apenas com as empresas brasileiras espera-se minimizar os problemas de variáveis omitidas apontados por Soderstrom e Sun (2007). Logo, pode-se controlar por variáveis institucionais que influenciam a relação entre custo de capital e adoção das IFRS, podendo variar a partir dos aspectos culturais, econômicos e políticos do país.

O modelo econométrico adaptado de Li (2010) para investigar o efeito das IFRS sobre o custo de capital é: 


$$
\begin{aligned}
& r_{P E G_{i t}}=\alpha_{0}+\alpha_{1} * \text { ado tan tes obrigatórios IFRS }+\alpha_{2} * \text { período pós adoção } \\
& +\alpha_{3} * \text { ado tan tes obrigatórios IFRS } * \text { período pós adoção }+\alpha_{4} * A D R_{i t}+ \\
& +\alpha_{5} * B C G I_{i t}+\alpha_{6} * \operatorname{SIZE}_{i t}+\alpha_{7} * R E T V A R_{i t}+\alpha_{8} * L E V_{i t}+\sum_{j}^{j-1} \varphi_{j} I n d+\varepsilon_{i t}
\end{aligned}
$$

Equação 15

As variáveis utilizadas para avaliar o impacto da adoção das normas internacionais no custo de capital são:

i) custo de capital estimado por meio do modelo Price Earnings Growth - PEG:

$$
\begin{aligned}
& r_{P E G}=\sqrt{\frac{e p s_{t+1}}{P_{1}} \times \text { growth }_{t+2}} \\
& \text { growth }_{t+2}=\frac{e p s_{t+2}-e p s_{t+1}}{e p s_{t+1}}
\end{aligned}
$$

Equação 16

onde $r_{P E G}$ é o custo de capital próprio, eps $s_{t+1}$ refere-se ao resultado por ação em $t+1$, $P_{1}$ é o preço da ação em $t$, e growth $_{t+2}$ é a taxa de crescimento do resultado de $t+2 \mathrm{em}$ relação a $t+1$ (LOPES; ALENCAR, 2010). O uso deste modelo justifica-se pela sua validade e utilidade observada para o mercado brasileiro, segundo Ohlson e Lopes (2007);

ii) "adotantes obrigatórios IFRS" é uma dummy que recebe 1 se a empresa adotou as normas internacionais a partir de 31/12/2010 e 0 caso contrário, isto é, as empresas que adotaram voluntariamente recebem 0 - ver apêndice;

iii) "período pós-adoção" é outra variável dummy que recebe 1 para o período de adoção (2010-2011) e 0 caso contrário (2000-2009);

iv) $A D R_{i t}$, ou American Depositary Receipt, é uma dummy que recebe 1 quando a empresa é emissora de ADR e 0 caso contrário;

v) $B C G I_{i t}$ é um índice de governança corporativa desenvolvido a partir de Lopes e Walker (2008), apresentado na seção 3.5;

vi) $S I Z E_{i t}$ é o logaritmo natural do ativo total para controlar o efeito tamanho;

vii) $R E T V A R_{i t}$ é desvio padrão dos retornos mensais das ações para um ano com o objetivo de captar a volatilidade dos papéis; 
viii) $\quad L E V_{i t}$ é dado pela relação entre dívida total e ativo total para representar o endividamento; e

ix) Ind corresponde a dummies adicionadas para controlar o efeito setor (LI, 2010).

A dummy ii) revela a diferença em termos de custo de capital entre os dois grupos (adoção obrigatória versus adoção voluntária). Por sua vez, a dummy iii) mostra a tendência de aumento ou diminuição de custo de capital, ou seja, é um efeito temporal. A multiplicação entre as dummies ii) e iii) descritas anteriormente revela o verdadeiro impacto da adoção obrigatória no custo de capital controlando o efeito temporal. Sendo assim, espera-se uma relação negativa entre esta variável interativa e custo de capital, indicando uma redução no custo de capital próprio no período da adoção obrigatória.

\subsection{A Aplicação do Portfolio Approach para Conteúdo Informacional}

Não há uma definição exata de qualidade da informação contábil na literatura (SODERSTROM; SUN, 2007). Na verdade, encontram-se diversas pesquisas que investigam dimensões diferentes da qualidade da informação contábil, tais como acurácia, conservadorismo, relevância, gerenciamento de resultados, comparabilidade, oportunidade e outras. O estudo de Dechow, Ge e Schrand (2010) oferece uma classificação das métricas utilizadas para qualidade do resultado ou earnings quality - EQ: i) propriedade dos resultados; ii) resposta dos investidores ao resultado; e iii) indicadores externos de distorção do resultado. Por outro lado, Francis, Olsson e Schipper (2008) consideram que EQ depende de dois aspectos: i) um considerado natural, pois reflete os fatores intrínsecos ao negócio; e ii) e outro mais discricionário, sendo influenciado por decisões da administração em termos de divulgação das demonstrações contábeis.

Diante da multidimensionalidade da qualidade da informação contábil, Barth et al (2006) sugere a utilização de um portfolio approach para observar o conteúdo informacional da contabilidade, sendo dividido nas seguintes dimensões: gerenciamento de resultados, conservadorismo, relevância e tempestividade. No entanto, na literatura de earnings quality há diversos modelos econométricos que podem ser aplicados para mensurar uma dimensão da qualidade. Posto isso, a aplicação de mais de um modelo para observar uma característica da informação contábil contribui para avaliar a validade do construto. 
Martins e Theóphilo (2009, p. 17) salientam que “[...] a validade do construto ${ }^{35}$ se refere ao grau em que um instrumento de medidas se relaciona consistentemente com outras medições assemelhadas derivadas da mesma teoria”. Sendo assim, pretende-se usar outros construtos para observar as dimensões comentadas e aumentar a validade dos resultados. Além disso, contribui para não cair na armadilha de "[...] supervalorização da matematização e a tecnificação, conferindo, por vezes, indevidamente, um desmedido prestígio ao modelo" (MARTINS, THEÓPHILO, 2009, p. 29).

No entanto, deve-se destacar que há diversos artigos científicos na literatura internacional e nacional, que adotaram algum modelo empírico para observar fenômenos de natureza semelhante, muitas vezes modelos considerados robustos e adequados para algumas situações. Neste contexto, Holthausen e Watts (2001), Barth, Beaver e Landsman (2001) e Barth (2006) fizeram um levantamento de diferentes modelos econométricos usados na literatura, além de apresentarem as suas limitações, o que é importante para aprimorar os modelos.

\subsubsection{Especificação dos Modelos de Gerenciamento de Resultados}

Uma das abordagens utilizadas para avaliar a qualidade da informação contábil é por meio de práticas de gerenciamento de resultado. Dechow (1994, p. 5) explica que:

[...] a gestão, normalmente, tem alguma discricionariedade sobre o reconhecimento dos accruals. Esta discricionariedade pode ser usada pela administração para sinalizar informação privada ou para, oportunisticamente, manipular resultados [...]. No entanto, na medida em que a gestão usa seu poder discricionário de forma oportuna para manipular os accruals, o resultado se tornará uma medida menos confiável para avaliar o desempenho da empresa $[\ldots]^{36}$.

Neste sentido, a discricionariedade pode ser exercida pelos gestores para aumentar a riqueza dos proprietários de capital ou expropriar a riqueza destes. A situação de expropriação da riqueza dos proprietários decorre de ações oportunistas por parte do gestor, o qual usa seu poder de julgamento para alcançar um objetivo pessoal que lhe favoreça, alterando a realidade

\footnotetext{
${ }^{35}$ Segundo Martins e Theóphilo (2009, p. 17) "um construto ou uma construção é uma variável, ou um conjunto de variáveis, isto é, uma definição operacional robusta que busca representar o verdadeiro significado teórico de um conceito".

36 Tradução livre de: "management typically have some discretion over the recognition of accruals. This discretion can be used by management to signal their private information or to opportunistically manipulate earnings [...]. However, to the extent that management use their discretion to opportunistically manipulate accruals, earnings will become a less reliable measure of firm performance [...]".
} 
econômico-financeira da empresa e, consequentemente, a análise dos usuários externos (NARDI, 2008).

Portanto, a prática ou a possibilidade de gerenciamento de resultados pode levantar dúvidas em relação à visão verdadeira e apropriada das demonstrações contábeis, característica qualitativa da informação contábil presente na estrutura conceitual, levando naturalmente os usuários da contabilidade a questionar a utilidade dos números contábeis. Em outras palavras, o gerenciamento de resultados pode influenciar a qualidade da informação gerada pela contabilidade. Uma das consequências do gerenciamento de resultados, ou uso da discricionariedade para atender propósitos específicos, é o maior custo de capital; evidências empíricas desta relação podem ser encontradas em Dechow e Dichev (2002) e Francis et al (2005).

A estimativa de gerenciamento de resultado pode ser feita por vários modelos. O primeiro modelo adotado nesta tese baseia-se em Barth et al (2006), que analisa a variabilidade de variações no lucro líquido dividido pelo ativo total:

$$
\begin{aligned}
& \Delta N I_{i t}=\alpha_{0}+\alpha_{1} M V E_{i t}+\alpha_{2} G R O W T H_{i t}+\alpha_{3} E_{S S U E}+\alpha_{4} D E B T_{i t}+\alpha_{5} D I S S U E_{i t}+ \\
& \alpha_{6} T_{U R N_{i t}}+\alpha_{7} C F_{i t}+\alpha_{8} A U D_{i t}+\alpha_{9} A D R_{i t}+\alpha_{10} I F R S_{i t}+\alpha_{11} V O L_{i t}+\alpha_{12} B C G I_{i t}+ \\
& +\sum_{j}^{j-1} \varphi_{j} \text { Ind }+\varepsilon_{i t}
\end{aligned}
$$

Equação 17

onde $\Delta N I_{i t}$ corresponde ao lucro em $t$ menos o lucro em $t-1$ da empresa $i$, esta diferença dividida pelo ativo total em $t$; Market Value of Equity ou $M V E_{i t}$ é o logaritmo natural do valor de mercado do patrimônio líquido em $t$ para a empresa $i$; GROWTH $H_{i t}$ é a porcentagem de variação nas vendas em $t$ para a empresa $i$; $E I S S U E_{i t}$ é uma mudança percentual na quantidade de ações ordinárias em $t$ para a empresa $i ; D E B T_{i t}$ é o total de dívidas dividido pelo total do patrimônio líquido em $t$ para a empresa $i$; DISSUE $E_{i t}$ é a mudança percentual no total de dívidas em $t$ para a empresa $i$; TURN $N_{i t}$ é a receita dividida pelo total de ativos em $t$ para a empresa $i ; C F_{i t}$ é o fluxo de caixa operacional líquido em $t$ para a empresa $i$; e $A U D_{i t}$ é uma dummy que recebe 1 quando a empresa é auditada por uma das Big Four e 0 caso contrário; $B C G I_{i t}$ é um índice de governança corporativa desenvolvido a partir de Lopes e Walker 
(2008), apresentado na seção 3.5; Ind corresponde a dummies adicionadas para controlar o efeito setor.

O fluxo de caixa operacional $(C F)$ é obtido pela diferença entre lucro líquido e accruals total (SLOAN, 1996). O cálculo do accruals fundamenta-se na Demonstração de Fluxo de Caixa Método Indireto, que apresenta a diferença entre lucro e caixa operacional. Esta diferença é explicada pela variação das contas operacionais de curto prazo, além de considerar aquelas contas que, embora tenham afetado o resultado, não causaram variações no caixa, como a despesa de depreciação (NARDI, 2008). Portanto, os accruals são estimados pela seguinte equação:

$$
A T_{j, t}=\Delta A C_{j, t}-\Delta P C_{j, t}-\Delta \text { Dispon }_{j, t}+\Delta P f C P_{j, t}-D E P A_{j, t}
$$

Equação 18

em que $A T_{j t}$ é o accrual total da empresa $j$ no período $t ; \Delta A C_{j t}$ é a variação do ativo circulante da empresa $j$ entre os anos $t-1$ e $t ; \Delta P C_{j t}$ é a variação do passivo circulante da empresa $j$ entre os anos $t$ - 1 e $t ; \Delta$ Dispon $_{j t}$ é a variação de disponibilidade da empresa $j$ entre os anos $t$ - 1 e $t$; $\triangle P f C P_{j t}$ é a variação do passivo financeiro de curto prazo da empresa $j$ entre os anos $t-1$ e $t$; e $D E P A_{j t}$ é a despesa de depreciação e amortização da empresa $j$ no período $t$ (DECHOW; SLOAN; SWEENEY, 1995).

É importante destacar o cálculo dos accruals totais possui algumas limitações, visto que a classificação das contas patrimoniais e de resultado pode ser diferente entre as empresas que compõem a amostra. Por exemplo, na demonstração de fluxo de caixa, a despesa financeira pode ser classificada como atividade operacional ou financeira de acordo com o CPC 03 (R2) - Demonstração dos Fluxos de Caixa, implicando em diferenças no fluxo de caixa operacional. Consequentemente, ao condicionar o fluxo de caixa operacional ao cálculo dos accruals totais, espera-se um resultado diferente ao encontrar empresas classificando despesas financeiras ora como operacional, ora como financeiro.

Feitas essas considerações, a premissa do modelo fundamenta-se na ideia de que, uma baixa variância do resultado líquido é uma evidência de earnings smoothing ou suavização do resultado líquido. Segundo Martinez (2001) o earnings smoothing significa um resultado estável com pequenas flutuações ao longo do tempo. Um incentivo para tal prática deve-se à 
necessidade de oferecer uma visão mais estável dos fluxos de resultados e reduzir a percepção de risco dos investidores. Logo, pequenas flutuações podem indicar o exercício de gerenciamento de resultados.

Barth et al (2006) explica que as variáveis SIZE, GROWTH, EISSUE etc. são adicionadas ao modelo, pois é provável que o resultado líquido seja sensível a várias características específicas das empresas não relacionadas à suavização dos resultados. Portanto, a medida de variabilidade do resultado é a variância dos resíduos gerados pela regressão.

Neste sentido, ao aplicar o modelo para o período completo (2000-2011), espera-se uma maior variância dos resíduos para o período de adoção completa das IFRS (2010-2011), indicando um menor nível de gerenciamento de resultados. O menor nível de gerenciamento pode indicar um menor uso da discricionariedade para "produzir" um resultado contábil, o que por sua vez, pode influenciar positivamente a qualidade da informação gerada pela contabilidade.

O segundo modelo aplicado nesta tese foi desenvolvido por Kang e Sivaramakrishnan (1995), a partir daqui KS. Segundo Martinez (2001), o modelo KS é aquele que descreve de maneira mais eficiente o processo de geração dos accruals no Brasil, possuindo superioridade em relação ao modelo Jones Modificado (MARTINEZ, 2001; ALMEIDA, 2010). Além disso, o KS foi utilizado em outros trabalhos nacionais, tais como, Martinez (2001), Paulo, Corrar, Martins (2006), Cardoso e Martinez (2006), Formigoni, Paulo e Pereira (2007), Paulo (2007), Nardi (2008).

Adicionalmente, os modelos de gerenciamento Jones Modificado (DECHOW; SLOAN; SWEENEY, 1995) e Teoh (TEOH; WELCH; WONG, 1998) são aplicados. Os três (KS, JM e TEOH) partem do raciocínio de que, os accruals totais são compostos por itens discricionários e não discricionários. Logo:

$$
A T=A D+A N D
$$

Equação 19

Em que $A T$ são os accruals totais; $A D$ são os accruals discricionários; e $A N D$ são os accruals não discricionários. 
Com o objetivo de separar $A D$ e $A N D$, os modelos KS, JM e TEOH exigem três passos: i) cálculo dos accruals; ii) estimação dos accruals não discricionários; e iii) estimação dos accruals discricionários (NARDI, 2008; NARDI; NAKAO, 2009; NARDI et al 2009).

Na primeira etapa, calculam-se os accruals totais para os modelos KS e JM de acordo com a equação 18. Para o modelo de Teoh é necessário calcular os accruals totais correntes, dado pela seguinte equação:

$$
A T C_{j, t}=\Delta A C_{j . t}-\Delta P C_{j, t}-\Delta \text { Dispon }_{j, t}+\Delta P f C P_{j, t}
$$

Equação 20

em que $A T C_{j t}$ é o accrual total corrente da empresa $j$ no período $t$. Nota-se que a única diferença em relação à equação 18 (accrual total) deve-se a despesa de depreciação e amortização, que é suprimida na equação 20. O accrual total corrente restringe-se à análise dos elementos presentes no ativo e passivo circulantes, implicando na desconsideração da despesa de depreciação que provoca variações no ativo não circulante (TEOH; WELCH; WONG, 1998).

Após o cálculo dos accruals totais, tem início a segunda etapa. Para o modelo Jones Modificado são estimados os parâmetros para as variáveis "variação na receita líquida" e "ativo imobilizado" por meio da equação 21 , e, em seguida, estimam-se os accruals não discricionários por meio da equação 22 .

$$
\frac{A T_{j, t}}{\text { Asset }_{j, t-1}}=\kappa_{1} \frac{1}{\text { Asset }_{j, t-1}}+\kappa_{2} \frac{\Delta \operatorname{Re} v_{j . t}}{\text { Asset }_{j, t-1}}+\kappa_{3} \frac{P P E_{j . t}}{\text { Asset }_{j, t-1}}+\varepsilon_{j, t}
$$

Equação 21

em que $A T_{j t}$ é o accrual total da empresa $j$ no período $t ; A_{s s e t}{ }_{j t-1}$ é o ativo total da empresa $j$ no início do período $(t-1) ; \Delta \operatorname{Rev}_{j t}$ é a variação da receita líquida da empresa $j$ entre os anos $t-1$ e $t$; $P P E_{j t}$ corresponde ao ativo imobilizado da empresa $j$ no ano $t$.

Uma das premissas do modelo de Jones (1991) considera que as receitas não são objeto de discricionariedade, implicando na remoção de parcela do gerenciamento de resultados devido 
às receitas. Em função disso, o modelo Jones Modificado é ajustado pela adição dos recebíveis - equação 22 - pois assume que toda a variação nos recebíveis é fruto de gerenciamento de resultados (DECHOW; SLOAN; SWEENEY, 1995).

Em seguida, pode-se estimar os accruals não discricionários pela seguinte equação:

$$
A N D_{j, t}=\hat{\kappa}_{1} \frac{1}{\text { Asset }_{j, t-1}}+\hat{\kappa}_{2} \frac{\left(\Delta \operatorname{Re} v_{j, t}-\Delta C R_{j . t}\right)}{\text { Asset }_{j, t-1}}+\hat{\kappa}_{3} \frac{P P E_{j, t}}{\text { Asset }_{j, t-1}}+\varepsilon_{j, t}
$$

Equação 22

em que $A N D_{j t}$ é o accrual não discricionário da empresa $j$ no período $t ; \Delta C R_{j t}$ é a variação do contas a receber da empresa $j$ entre $t-1$ e $t$.

Para o modelo Teoh, inicialmente, utiliza-se a equação 23 para calcular os parâmetros necessários para estimar os accruals não discricionários.

$$
\frac{\operatorname{ATC}_{j, t}}{\text { Asset }_{j, t-1}}=\gamma_{1} \frac{1}{\text { Asset }_{j, t-1}}+\gamma_{2} \frac{\Delta \operatorname{Re} v_{j . t}}{\text { Asset }_{j, t-1}}+v_{j, t}
$$

Equação 23

Posteriormente, estimam-se os accruals não discricionários:

$$
A N D_{j, t}=\hat{\gamma}_{1} \frac{1}{\text { Asset }_{j, t-1}}+\hat{\gamma}_{2} \frac{\left(\Delta \operatorname{Re} v_{j . t}-\Delta C R_{j, t}\right)}{A s s e t_{j, t-1}}
$$

Equação 24

Na terceira etapa calculam-se os accruals discricionários para os modelos JM (equação 25) e TEOH (equação 26):

$$
A D_{j, t}=\frac{A T_{j, t}}{\text { Asset }_{j, t-1}}-A N D_{j, t}
$$

Equação 25

$$
A D_{j, t}=\frac{A T C_{j, t}}{\text { Asset }_{j, t-1}}-A N D_{j, t}
$$

Equação 26

Ao contrário dos modelos TEOH e JM, o KS permite a estimação dos accruals discricionários em uma etapa. Além disso, ele tenta eliminar alguns problemas metodológicos observados 
nos modelos anteriores, tais como: i) simultaneidade; ii) erro nas variáveis; e iii) variáveis omitidas.

A fundamentação do modelo KS consiste na separação dos accruals discricionários e não discricionários. Considere que os accruals totais são formados a partir de:

$$
\begin{aligned}
& A T_{t}=A R_{t}+I N V_{t}+O C A_{t}-C L_{t}-D E P_{t} \\
& A T_{t}=\left(A R_{t}^{*}+I N V_{t}^{*}+O C A_{t}^{*}-C L_{t}^{*}-D E P_{t}^{*}\right)+\left(D A_{t}^{s}+D A_{t}^{e}+D A_{t}^{d}\right) \\
& A T_{t}=A T_{t}^{*}+D A_{t}
\end{aligned}
$$

Equação 27

onde $A T_{t}$ é accrual total em $t ; A R_{t}$ é o contas a receber em $t ; I N V_{t}$ é estoque em t; $O C A_{t}$ é a despesa antecipada em $t ; C L_{t}$ refere-se às contas a pagar de curto prazo em $t$; e $D E P_{t}$ é despesa de depreciação em $t ; A{ }^{*}{ }_{t}$ corresponde ao accrual total isento de gerenciamento de resultados, e as outras contas com asterisco também estão livres de gerenciamento; $D A^{s}{ }_{t}$ é a parcela das vendas a prazo adicionada as contas a receber $(A R)$, oriunda de práticas de gerenciamento de resultado; $D A^{e}{ }_{t}$ é a parcela de despesa ou custo adicionada às contas de estoque (INV), despesa antecipada $(O C A)$ e contas a pagar de curto prazo $(C L)$ dada por práticas de gerenciamento de resultado; e $D A^{d}{ }_{t}$ é a parcela de despesa de depreciação explicada por práticas de gerenciamento de resultado. Sendo assim, $D A_{t}$ é o total de accruals que representa as práticas de gerenciamento de resultado em $t$ (KANG; SIVARAMAKRISHNAN, 1995).

O diferencial do modelo de Kang e Sivaramakrishnan (1995) consiste na utilização de variáveis instrumentais a partir de contas do balanço patrimonial. Por exemplo, a relação entre contas a receber $\left(A R^{*}\right)$ e receita de vendas $\left(R E V^{*}\right)$ é dada por:

$$
\frac{A R_{t}^{*}}{R E V_{t}^{*}}=\phi_{1} \frac{A R_{t-1}^{*}}{R E V_{t-1}^{*}}+v_{t}
$$

Equação 28

Ao multiplicar a equação anterior por $R E V^{*}{ }_{t}$, tem-se: 


$$
\begin{aligned}
& \left(\frac{A R_{t}^{*}}{R E V_{t}^{*}}\right) \times R E V_{t}^{*}=\left(\phi_{1} \frac{A R_{t-1}^{*}}{R E V_{t-1}^{*}}+v_{t}\right) \times R E V_{t}^{*} \\
& A R_{t}^{*}=\phi_{1} \frac{A R_{t-1}^{*}}{R E V_{t-1}^{*}} \times R E V_{t}^{*}+\varphi_{t}
\end{aligned}
$$

Equação 29

onde $\varphi_{t}=v t x R E V_{t}^{*}$. Nota-se que a parcela não discricionária da variável $A R^{*}{ }_{t}$ é dada pela multiplicação entre a relação $A R^{*} / R E V^{*}$, ambas em $t-1$, e $R E V^{*}$. Neste sentido, a parcela discricionária é alocada aos resíduos $\left(\varphi_{t}\right)$, de acordo com as premissas do modelo.

Ao repetir a mesma análise para as demais variáveis, pode-se estimar os accruals discricionários a partir do seguinte modelo:

$$
A T_{j, t}=\phi_{0}+\phi_{1} \times\left[\frac{C R_{j, t-1}}{\operatorname{Re} v_{j, t-1}} \times \operatorname{Re} v_{j, t}\right]+\phi_{2} \times\left[\frac{A P B_{j, t-1}}{E X P_{j, t-1}} \times E X P_{j, t}\right]+\phi_{3} \times\left[\frac{D E P_{j, t-1}}{P P E_{j, t-1}} \times P P E_{j, t}\right]+v_{j, t}
$$

Equação 30

onde $A T$ são os accruals totais da empresa $j$ em $t$ sobre o ativo total da empresa $j$ em $t$-1; $A P B_{j t-1}$ é o capital de giro líquido sem considerar contas a receber da empresa $j$ no período $t-1$; $E X P_{j t-1}$ é a despesa operacional antes da depreciação e amortização da empresa $j$ no período $t$ 1; $E X P_{j t}$ é a despesa operacional antes da depreciação e amortização da empresa $j$ no período $t ; D E P_{j t-1}$ é a despesa de depreciação e amortização da empresa $j$ no período $t$ - 1 .

A endogeneidade está presente entre Rev, EXP, PPE e os accruals totais $(A T)$, visto que aquelas explicam o comportamento dos $A T$, enquanto este pode influenciar as variáveis explicativas. Por exemplo, as despesas operacionais de um período podem influenciar, juntamente com outras variáveis, o nível de accruals da empresa, conforme prevê o modelo. No entanto, assumindo que níveis elevados de accruals podem influenciar as decisões dos gestores a respeito do reconhecimento de receitas e despesas (SLOAN, 1996), é possível observações ações discricionárias voltadas para a redução do nível de accruals e, consequentemente, variações nas contas que compõem Rev, EXP e PPE. Isso fica mais claro no caso de uma estimativa de gastos com serviço de garantia, propositalmente, superavaliada reconhecida em $t$, que, proporciona um determinado efeito nos accruals da empresa naquele período. No entanto, visando uma alteração nos $A T$ após $t$, os administradores podem recorrer 
a reversões das despesas de garantias, causando o problema da endogeneidade. Em função disso, sugerem-se as variáveis intrumentais (IV) que multiplicam Rev, EXP e $P P E$ na equação 30.

Após estimar a equação 30, os resíduos podem ser usados como uma proxy do componente de discricionariedade, sendo que os valores previstos são considerados estimativas da parcela não discricionária.

Finalmente, as proxies de gerenciamento de resultado podem ser calculadas com base nas equações 25,26 e 30. Coerente com a hipótese de gerenciamento de resultados espera-se uma redução em tais proxies em 2010 e 2011, período da adoção completa das IFRS, revelando aumento na qualidade da informação contábil. Recorda-se que a vantagem em estimar gerenciamento de resultados por meio de vários modelos é a possibilidade de verificar se os construtos estão convergindo, contribuindo para aumentar a validade dos resultados.

Outra abordagem que permite investigar se o nível de AD reduziu-se estatisticamente no período da adoção obrigatória (2010-2011) é baseada no modelo usado por Tendeloo e Vanstraelen (2005):

$$
\left|A D_{K S_{i t}}\right|=\beta_{0}+\beta_{1} I F R S_{i t}+\beta_{2} A D R_{i t}+\beta_{3} B C G I_{i t}+\beta_{4} C F_{i t}+\beta_{5} D E B T_{i t}+\varepsilon_{i t}
$$

Equação 31

onde $\left|A D_{K S i t}\right|$ são os accruals discricionários estimados pelo modelo $\mathrm{KS}^{37}$ para a empresa $i$ em t; IFRS é uma dummy que recebe 1 para o período de adoção obrigatória; BCGI é um índice de governança corporativa desenvolvido a partir de Lopes e Walker (2008), apresentado na seção 3.5; ADR é uma dummy que recebe 1 para as empresas que emitem ADRs na NYSE; $C F$ é o fluxo de caixa operacional estimado pela diferença entre lucro líquido e accruals total (SLOAN, 1996); e DEBT é o total de dívidas dividido pelo total do patrimônio líquido.

Neste caso, a variável de interesse é IFRS, que revela o comportamento dos accruals discricionários durante o período da adoção completa. Espera-se que o coeficiente $\beta_{1}$ seja negativo, indicando uma redução no nível de gerenciamento.

\footnotetext{
${ }^{37}$ Optou-se por considerar os $\mathrm{AD}$ do modelo KS em função de sua adequação às empresas brasileiras.
} 


\subsubsection{Especificação dos Modelos de Conservadorismo Condicional}

O primeiro modelo para observar conservadorismo condicional baseia-se em Basu (1997):

$$
E A R N_{i t}=\alpha+\beta_{1} D R_{i t}+\beta_{2} \operatorname{Re} t_{i t}+\beta_{3} D R_{i t} * \operatorname{Re} t_{i t}+\varepsilon_{j t}
$$

Equação 32

onde $E A R N$ é o resultado por ação da empresa $i$ para o ano $t$; Ret é o retorno do preço da ação para a empresa $i$ no ano $t$; e $D R$ é uma dummy que assume 1 quando o retorno da ação é negativo e 0 caso contrário.

Segundo Lopes e Walker (2008, p. 27) a interpretação do modelo deve ser feita da seguinte maneira: se o resultado possui característica de conservadorismo, então espera-se que a soma dos coeficientes $\beta_{2}$ e $\beta_{3}$ seja maior que $\beta_{2}$. O parâmetro $\beta_{3}$ também é conhecido por coeficiente Basu.

Essa análise fundamenta-se na comparação entre o retorno da ação para todas as empresas da amostra $\left(\beta_{2}\right)$ e o retorno da ação para as empresas que possuem retorno negativo $\left(\beta_{2}+\beta_{3}\right)$, pois ao colocar em evidência o Ret tem-se:

$$
\begin{aligned}
& E A R N_{i t}=\alpha+\beta_{1} D R_{i t}+\beta_{2} \operatorname{Ret}_{i t}+\beta_{3} D R_{i t} * \operatorname{Ret}_{i t}+\varepsilon_{j t} \\
& E A R N_{i t}=\alpha+\beta_{1} D R_{i t}+\operatorname{Ret}_{i t}\left(\beta_{2}+\beta_{3} D R_{i t}\right)+\varepsilon_{j t}
\end{aligned}
$$

Equação 33

Ao considerar as empresas com retorno negativo substitui-se $D R$ por 1:

$$
E A R N_{i t}=\alpha+\beta_{1} D R_{i t}+\operatorname{Ret}_{i t}\left(\beta_{2}+\beta_{3}\right)+\varepsilon_{j t}
$$

Equação 34

$\mathrm{Na}$ verdade, o modelo pressupõe que o retorno da ação é uma proxy para o resultado econômico da empresa. Logo, a regressão permite analisar se o resultado contábil incorpora o resultado econômico dado pela significância dos coeficientes, além de avaliar a oportunidade 
ou tempestividade do seu reconhecimento contábil. Em outras palavras, o mercado reage à divulgação tempestiva de números conservadores, devido à antecipação de resultados desfavoráveis (PAULO; ANTUNES; FORMIGONI, 2008; FRANCIS; MARTIN, 2010).

Além disso, dada à natureza transitória do resultado econômico, quanto menos oportuno for o reconhecimento contábil do resultado econômico, maior será o ruído incorporado na demonstração de resultado e nos valores do balanço, reduzindo, assim, a qualidade das demonstrações contábeis (BALL; ROBIN; WU, 2003).

Para analisar a adoção completa às IFRS, a dummy IFRS foi acrescentada na equação 32, além das variáveis ADR e BCGI. Espera-se que a estimativa do coeficiente Basu quando da adição da dummy IFRS seja maior, revelando maior conservadorismo condicional, e, consequentemente, maior conteúdo informacional. Adicionalmente, as dummies de BCGI e ADR podem capturar os incentivos que algumas empresas possuem para divulgar demonstrações contábeis com maior qualidade. Portanto, considerando que há indícios de uma relação positiva entre qualidade da informação contábil e governança corporativa (LOPES; WALKER, 2008; FRANCIS; MARTIN, 2010; GABRIEL, 2011), espera-se que BCGI e ADR revelem um coeficiente Basu maior.

O segundo modelo aplicado nesta tese para estimar conservadorismo condicional também tem origem no paper de Basu (1997). Segundo o autor, o conservadorismo resulta em baixa persistência $^{38}$ dos lucros em períodos de más notícias em relação aos períodos de boas notícias, sendo explicado pela diferença entre os conceitos de oportunidade e persistência. $\mathrm{O}$ autor explica que, enquanto uma informação oportuna reflete fatos relevantes imediatamente no resultado, a informação persistente reconhece os fatos relevantes no atual e nos próximos exercícios sociais. Portanto, espera-se que o lucro seja mais oportuno e menos persistente no contexto de más notícias. É importante lembrar que o conservadorismo implica na antecipação de perdas futuras, as quais são reconhecidas no resultado corrente. Consequentemente, os lucros futuros são imunes às más notícias correntes, levando-os a níveis satisfatórios, ou seja, isentos das más notícias. Basu (1997) define este fenômeno como

\footnotetext{
${ }^{38}$ É importante lembrar que uma persistência alta significa que processos autoregressivos são relevantes na previsão de resultados futuros. Se a persistência é pequena, o comportamento temporal do resultado não tem tanta influência na explicação do seu valor corrente, indicando uma baixa qualidade do resultado (FRANCIS; OLSSON; SCHIPPER, 2008).
} 
a reversão da redução do lucro corrente (em função de más notícias) no próximo exercício social. O modelo usado para investigar tal comportamento é denominado de componentes transitórios de ganhos e perdas (BALL; SHIVAKUMAR, 2005) e sua especificação pode ser definida como:

$$
\triangle E A R N_{i t}=\alpha+\beta_{1} D \Delta E A R N_{i t-1}+\beta_{2} \Delta E A R N_{i t-1}+\beta_{3} D \Delta E A R N_{i t-1} * \Delta E A R N_{i t-1}+\varepsilon_{j t}
$$

Equação 35

onde $\triangle E A R N_{i t}$ é a variação do lucro em $t$ para a empresa $i$; DLEARN $N_{i t-1}$ é uma dummy que assume 1 quando a variação do lucro em $t$ - 1 para a empresa $i$ é negativa e 0 caso contrário; a variável interativa $D \triangle E A R N_{i t-1} * \triangle E A R N_{i t-1}$ corresponde à variação do lucro para as empresas que possuem redução no resultado contábil. A principal interpretação do modelo consiste na avaliação e comparação dos coeficientes $\beta_{2}$ e $\beta_{3}$. Se, em média, as empresas estão reconhecendo as más notícias antecipadamente (em $t$-l) e revertendo o efeito no exercício social seguinte (em $t$ ), o coeficiente $\beta_{3}$ deve ser negativo, revelando o reconhecimento oportuno de perdas.

Ball e Shivakumar (2005) explicam o reconhecimento assimétrico entre ganhos e perdas neste modelo. Quando os ganhos econômicos são reconhecidos de maneira conservadora, há uma tendência em reconhecê-los em períodos futuros, pois as condições de realização se tornam mais claras. Neste contexto, os ganhos representam um elemento de persistência e sem tendência a reversão, implicando em um coeficiente $\beta_{2}$ igual a zero. No entanto, quando há um reconhecimento oportuno dos ganhos, tais valores passam a apresentar uma característica de transitoriedade, implicando em tendência à reversão. Consequentemente, o coeficiente esperado para $\beta_{2}$ passa a ser menor que zero. No caso das perdas econômicas, o seu reconhecimento oportuno implica em transitoriedade e reversão, resultando em $\beta_{2}+\beta_{3}<0$. Neste sentido, pode-se afirmar que as perdas são reconhecidas de maneira mais tempestiva que os ganhos quando $\beta_{3}<0$.

A dummy IFRS foi acrescentada no modelo original para avaliar o efeito das normas internacionais no reconhecimento oportuno e persistente das demonstrações contábeis. Em consonância à hipótese de conservadorismo, espera-se que o coeficiente associado à dummy de IFRS apresente sinal negativo, além de maior magnitude, revelando um efeito adicional em relação ao modelo original. Ademais, as dummies de BCGI e ADR também foram 
adicionadas para analisar os incentivos ao maior conservadorismo, devido às práticas de governança corporativa.

O terceiro modelo aplicado nesta tese é o de Ball e Shivakumar (2005), usado para avaliar o reconhecimento oportuno de perdas e ganhos por meio de accruals. Segundo os autores, há uma correlação positiva entre accruals e fluxo de caixa. Por exemplo, considere o caso de um ativo com capacidade para gerar fluxo de caixa $-C F$ durante $t$ anos. No caso de revisão do fluxo de caixa corrente dado por $\Delta C F_{t}$, espera-se que os fluxos de caixa futuros também sejam revisados, gerando uma correlação positiva entre eles. Neste sentido, o reconhecimento de ganhos e perdas é baseado na expectativa de ocorrência de fluxos de caixa, e não pela sua própria realização. Portanto, esse processo pode ser considerado uma fonte de correlação positiva entre fluxo de caixa corrente e accruals.

A assimetria ocorre, de acordo com Ball e Shivakumar (2005), devido ao reconhecimento oportuno de perdas econômicas ainda não realizadas, uma vez que, os ganhos econômicos são reconhecidos quando realizados. Assim, a correlação entre accruals e fluxo de caixa é maior para os casos de perdas. Esta relação pode ser observada no seguinte modelo:

$$
A T_{i t}=\alpha+\beta_{1} D C F O_{i t}+\beta_{2} C F O_{i t}+\beta_{3} D C F O_{i t} * C F O_{i t}+\varepsilon_{i t}
$$

Equação 36

onde $A T_{i t}$ é dado pela equação 18 , dividido pelo ativo em $t-1 ; C F O_{i t}$ é o fluxo de caixa operacional, dividido pelo ativo em $t-1 ; D F C O_{i t}$ é uma dummy que recebe 1 quando o $C F O$ é negativo e 0 caso contrário. Segundo Ball e Shivakumar (2005), as perdas são mais prováveis em períodos de fluxo de caixa negativo, portanto, espera-se um coeficiente $\beta_{3}$ positivo. Complementarmente, Coelho (2007) explica que esta expectativa é baseada na correlação positiva entre ajustes advindos do regime de competência e fluxos de caixa operacionais. Portanto, para o período de adoção completa (IFRS), a expectativa é de observar maior reconhecimento oportuno de perdas, que pode ser dado por um coeficiente positivo e maior em relação ao modelo original. As dummies ADR e BCGI também foram adicionadas para avaliar o reconhecimento oportuno de perdas diante de incentivos para maior qualidade das demonstrações contábeis. 


\subsubsection{Especificação do Modelo de Relevância da Informação Contábil}

Em seguida, pode-se adotar uma abordagem metodológica semelhante à de Easton (1999), Lopes (2005) e Chalmers, Clinch e Godfrey (2011) com o propósito de investigar a relevância da informação contábil no mercado brasileiro. O modelo adotado para análise de relevância é:

$$
\frac{P_{i t}}{P_{i t-1}}=\alpha_{0 t}+\beta_{1 t} \frac{B V_{i t}}{P_{i t-1}}+\beta_{2 t} \frac{E A R N_{i t}}{P_{i t-1}}+\varepsilon_{i t}
$$

Equação 37

onde $P$ é o preço da ação três meses após o encerramento do ano fiscal em $t$, deflacionado pelo preço em $t-1$ para a empresa $i ; B V$ é o patrimônio líquido por ação da empresa $i$ para o período $t$, deflacionado pelo preço em $t-1 ; E A R N$ é o resultado líquido por ação da empresa $i$ para o período $t$, deflacionado pelo preço em $t$ - 1 . O objetivo de dividir pelo preço em $t-1$ é reduzir problemas de escala conforme sugestão de Brown, Lo e Lys (1999).

A aplicação da equação 37 revela uma das características da qualidade da informação contábil investigada: a relevância das demonstrações contábeis para o mercado de capitais. No entanto, o objetivo desta tese é investigar a relevância durante a adoção completa das IFRS; para isso a equação 37 será estimada a partir de interações com a dummy de IFRS. Além disso, as variáveis BCGI e ADR também foram incluídas no modelo com o intuito de avaliar se a qualidade da informação contábil é sensível aos mecanismos de redução de assimetria de informação.

\subsubsection{Especificação do Modelo de Tempestividade da Informação Contábil}

Para avaliar timeliness ou tempestividade das informações contábeis pode-se usar a seguinte especificação baseada em Lopes e Walker (2008):

$$
\operatorname{Re} t_{i t}=\alpha+\beta_{1} E A R N_{i t}+\beta_{2}\left(E A R N_{i t}-E A R N_{i t-1}\right)+\varepsilon_{i t}
$$

Equação 38 
onde $\operatorname{Ret}_{i t}$ é o retorno da ação para a empresa $i$ no ano $t ; E A R N_{i t}$ é o lucro por ação da empresa $i$ no ano $t$; $E A R N_{i t-1}$ é o lucro por ação da empresa $i$ no ano $t$-1. As variáveis de lucro são deflacionadas pelo preço em $t$ - 1 , com o propósito de reduzir problemas de escala.

A lógica do modelo de tempestividade baseia-se na associação entre o lucro e o retorno da ação. A informação contábil é considerada tempestiva ou oportuna no mercado de capitais quando o retorno da ação em $t$ reflete a variação do lucro entre $t$ e $t-1$. Portanto, diz-se que a informação é oportuna quando o coeficiente $\beta_{2}$ apresenta-se significante estatisticamente.

Direcionando a análise para o objetivo da tese, a avaliação da oportunidade ou tempestividade das demonstrações contábeis full IFRS deve ser feita por meio de uma interação entre as variáveis do modelo original e a dummy de IFRS. Espera-se que a informação contábil após adoção obrigatória seja mais oportuna, o que pode ser observado por um aumento no coeficiente gerado pela interação entre $\left(E A R N_{i t}-E A R N_{i t-1}\right)$ e IFRS. A interação entre IFRS, BCGI e ADR também é realizada para avaliar o efeito de aspectos institucionais.

\subsubsection{Estudo de Evento}

Para atender ao objetivo desta tese, utilizou-se o método "estudo de evento" que verifica se o efeito de um evento será refletido no preço das ações. A ideia é que, o impacto econômico do evento possa ser mensurado por meio da observação do preço dos títulos, a partir de um período (CAMPBELL; LO; MACKINLAY, 1997).

Este método ganhou grande apreço na comunidade acadêmica ao ser usado por Fama et al (1969) e Ball e Brown (1968), autores que usaram esta abordagem metodológica para investigar o comportamento do mercado diante de determinados eventos. Este último trabalho identificou que o conteúdo informacional do resultado é antecipado pelo mercado antes da publicação das demonstrações contábeis.

De acordo com Binder (1998) o estudo de evento é o método padrão para analisar a reação do preço das ações a partir de eventos. $\mathrm{O}$ autor afirma que este método tem sido usado por duas razões: i) testar a hipótese nula de que o mercado é eficiente; e ii) sob a hipótese de mercado eficiente (informação disponível publicamente) para investigar o impacto de alguns eventos no mercado de ações. 
O evento objeto de análise (dia zero) desta tese corresponde à divulgação pela primeira vez das demonstrações contábeis full IFRS, regulada pelo CPC 37 intitulado "Adoção Inicial das Normas Internacionais de Contabilidade”. A janela do evento compreende os 5 dias anteriores à data do evento e os 5 dias posteriores à mesma data. Considerando que as empresas divulgaram duas demonstrações contábeis em datas diferentes (vide apêndice 1), foram obtidas janelas de evento distintas. Adotou-se uma janela de estimação de 1.320 dias e uma janela de lag de 5 dias, esta última para eliminar um possível efeito dado pelo vazamento das informações contábeis. Para aumentar a robustez dos resultados decidiu-se analisar as 103 empresas (subtotal 3) da tabela 3, que inclui as empresas do setor de Finanças e Seguros. Porém, duas empresas (TERI3 e VULC3) foram excluídas, pois não tinham dados para o período de estimação.

Adotou-se o modelo de mercado para calcular o retorno anormal de um título. Segundo Campbell, Lo e Mackinlay (1997), esta abordagem relaciona o retorno de uma ação com o retorno do portfólio de mercado. Para qualquer ação $i$ tem-se:

$$
\begin{aligned}
& R_{i t}=\alpha_{i}+\beta_{i} R_{m t}+\varepsilon_{i t} \\
& E\left[\varepsilon_{i t}\right]=0 \\
& \operatorname{Var}\left[\varepsilon_{i t}\right]=\sigma_{\varepsilon i}^{2}
\end{aligned}
$$

Equação 39

sendo que $R_{i t}$ e $R_{m t}$ são, respectivamente, os retornos do título $i$ e do portfólio do mercado no período $t ; \varepsilon_{i t}$ é o termo médio de perturbação; $\alpha_{i}, \beta_{i}$ e $\sigma_{\varepsilon i}^{2}$ são os parâmetros do modelo de mercado. Nesta abordagem a variância do retorno anormal é reduzida devido à remoção da parcela do retorno que é relacionada ao desvio do retorno de mercado. Com isso pode-se aumentar a habilidade em detectar efeitos dos eventos (CAMPBELL; LO; MACKINLAY, 1997). O cálculo dos retornos diários das ações segue a seguinte equação:

$$
R_{i}=\operatorname{Ln}\left(\frac{P_{t}}{P_{t-1}}\right)
$$

Equação 40 
na qual $P_{t}$ é o preço de determinada ação em $t ; P_{t-1}$ é o preço da mesma ação em $t$ - 1 ; e $R_{i}$ é o retorno do título $i$ pelo método de capitalização contínua. Este método possibilita uma maior robustez nos resultados de acordo com Brooks (2002).

Uma vez definido o cálculo dos retornos das ações, pode-se obter os parâmetros $\alpha_{i}$ e $\beta_{i}$ pelo método dos Mínimos Quadrados Ordinários (MQO) entre os retornos das ações e da carteira teórica do IBOVESPA. É importante destacar que o método é aplicado para a janela de estimação, que foi definida anteriormente. Em seguida, pode-se seguir para o cálculo do retorno anormal diário para a ação $i$ :

$$
A R_{i t}=R_{i t}-\left(\alpha_{i}+\beta_{i} R_{m t}\right)
$$

Equação 41

em que $A R_{i t}$ é retorno anormal da ação $i$ na data $t ; R_{i t}$ é o retorno da ação $i$ na data $t ; \alpha_{i}$ e $\beta_{i}$ são os parâmetros obtidos por meio do modelo de mercado; e $R_{m t}$ é o retorno de mercado na data t. Para que se possa concluir a respeito do impacto do evento no retorno anormal, este deve ser agregado. Segundo Campbell, Lo e Mackinlay (1997), a agregação pode ser feita por meio de duas dimensões: uma pelo tempo e por ação, e a outra que considera a agregação dos títulos pelo tempo. A acumulação dos retornos anormais, de acordo com a segunda dimensão, permite uma visão conjunta do impacto do evento no mercado, sendo dada por:

$$
\overline{D A R_{t}}=\frac{1}{N} \sum_{i=1}^{N} A R_{i t}
$$

Equação 42

onde $\overline{D A R_{t}}$, ou Daily Abnormal Returns, corresponde a média dos retornos anormais no período $t$. Além disso, a acumulação dos retornos anormais pode ser apresentada ao longo do tempo e por ação, como pode ser visto a seguir.

$$
\operatorname{CAR}_{i}\left(t_{1}, t_{2}\right)=\sum_{t=t_{1}}^{t_{2}} A R_{i t}
$$

Equação 43 
na qual $C A R_{i}$, ou Cumulative Abnormal Returns, refere-se à agregação do retorno anormal para múltiplos intervalos dentro da janela do evento. E, finalmente, o retorno anormal médio é obtido pela seguinte fórmula:

$$
\overline{C A R}\left(t_{1}, t_{2}\right)=\frac{1}{N} \sum_{i=1}^{N} \operatorname{CAR}_{i}\left(t_{1}, t_{2}\right)
$$

Equação 44

em que $\overline{C A R}$ representa a agregação do retorno anormal acumulado calculado na equação 43 .

A partir destes cálculos, pode-se aplicar o teste dos sinais. Segundo Campbell, Lo e Mackinlay (1997), este teste baseia-se nos sinais dos retornos anormais e exige que os mesmos sejam independentes entre as ações. Além disso, espera-se que a proporção dos retornos anormais positivos sob a hipótese nula seja 0,5. A fundamentação para este teste é que, sob a hipótese nula, a proporção (p) de retornos anormais positivos é igual à proporção de retornos anormais negativos, ou seja, a divulgação pela primeira vez das demonstrações contábeis full IFRS não contribuiu significativamente para provocar uma alteração nos retornos anormais. Portanto, as hipóteses para este teste são:

$\mathrm{H}_{0}: \mathrm{p}=0,5$

$\mathrm{H}_{1}: \mathrm{p}>0,5$.

Sendo assim, o resultado deste teste fornece um indício para avaliar a oportunidade ou timeliness das demonstrações contábeis full IFRS. Portanto, espera-se encontrar uma diferença significante estatisticamente entres as médias dos retornos anormais acumulados. A estatística teste é:

$$
J=\left[\frac{N^{+}}{N}-0,5\right] \frac{N^{1 / 2}}{0,5} \sim N(0,1)
$$

Equação 45

em que N+é o número de casos com retorno anormal positivo. 


\subsubsection{O Conteúdo Informacional na Janela de Evento}

Esta subseção descreve a aplicação de modelos voltados para a análise da qualidade das demonstrações contábeis no curto prazo. A análise do conteúdo informacional na janela do evento baseia-se em Horton e Serafeim (2009), sendo dividida em duas abordagens: i) análise da tempestividade das demonstrações contábeis na janela do evento -5 dias antes e 5 dias após a divulgação pela primeira vez das demonstrações contábeis full IFRS; ii) e análise da relevância da informação contábil no mesmo período.

A investigação do conteúdo informacional no ano da adoção inicial tem uma vantagem em relação aos outros períodos de adoção das IFRS, que corresponde à análise comparativa dos números contábeis em IFRS e BRGAAP, visto que ambos são exigidos pelo CPC 37 na adoção inicial das IFRS. Ressalta-se que o CPC 37 exige o ajuste de conciliação ${ }^{39}$ na data de transição ${ }^{40}$ e no primeiro período de divulgação em IFRS. Assim, optou-se por trabalhar com os ajustes de conciliação do primeiro período de divulgação em IFRS, por representarem a realidade financeira da empresa mais recente.

Para analisar a tempestividade e a relevância da informação no curto prazo, as variáveis necessárias são: i) lucro ou prejuízo em IFRS e BRGAAP; ii) patrimônio líquido em IFRS e BRGAAP; iii) retorno anormal acumulado para a janela de evento de acordo com Campbell, Lo e Mackinlay (1997); iv) diferença entre o resultado líquido full IFRS e resultado líquido de acordo com BRGAAP; v) diferença entre o patrimônio líquido full IFRS e resultado líquido de acordo com BRGAAP.

Neste contexto, o modelo adaptado de Horton e Serafeim (2009) foi usado para avaliar a tempestividade da informação contábil, representada pela diferença entre lucro em IFRS e BRGAAP.

$$
C A R_{-5+5}=\alpha_{0}+\beta_{1} E R N_{i}^{I F R S-B R G A A P}+\beta_{2} A D R_{i}+\beta_{3} V O L_{i}+\beta_{4} B C G I_{i}+\varepsilon
$$

Equação 46

\footnotetext{
39 A conciliação dos números contábeis, entre eles patrimônio líquido e resultado, corresponde à apresentação destes valores de acordo com os critérios contábeis anteriores (BRGAAP), e segundo os critérios do novo GAAP (IFRS), explicando as causas das diferenças.

${ }^{40}$ De acordo com o CPC 37, data de transição é o início do primeiro período para o qual a entidade apresenta informação comparativa completa pelas IFRSs em suas primeiras demonstrações contábeis em IFRSs.
} 
onde $C A R_{-5+5}$ corresponde ao retorno anormal acumulado para uma janela de evento de 5 dias antes e após a data de divulgação das demonstrações contábeis de acordo com as normas internacionais; $E R N$ refere-se a diferença entre o resultado do exercício de acordo com as IFRS e o resultado BRGAAP; ADR, ou American Depositary Receipt, é uma dummy que recebe 1 quando a empresa é emissora de ADR e 0 caso contrário; VOL é uma dummy que assume 1 para casos de adoção voluntária e 0 caso contrário; BCGI é um índice de governança corporativa baseado em Lopes e Walker (2008); $\varepsilon$ é o erro aleatório do modelo; $\alpha_{0}, \beta_{1}, \beta_{2}$ e $\beta_{3}$ são os parâmetros gerados pela regressão. A variável $A D R$ é necessária já que as empresas que possuem ações negociadas no mercado norte-americano tendem a apresentar maior nível de disclosure em relação às demais empresas. Assim, torna-se interessante avaliar as diferenças das empresas com ações negociadas apenas no mercado nacional em relação àquelas que emitem $\mathrm{ADR}$, uma vez que estas também divulgam suas demonstrações contábeis em USGAAP. No caso da variável ERN IFRS-BRGAAP, espera-se obter um coeficiente $\beta_{1}$ estatisticamente significante e positivo, revelando que a informação contábil é tempestiva.

A equação 46 aproxima-se do modelo usado por Harris e Muller (1999), os quais investigaram a relação entre retorno das ações e as variáveis contábeis de conciliação, pois apresenta menos problemas econométricos (KOTHARI; ZIMMERMAN, 1995; CHRISTIE, 1987). Este modelo também foi usado por Amir, Harris e Venuti (1993) que investigou ajustes de conciliação de sistemas contábeis diferentes.

Apesar deste esforço em avaliar a tempestividade da informação contábil, sabe-se que o mercado pode antecipar parcela do ajuste de conciliação divulgado pelas empresas. Uma alternativa é estimar a parcela não antecipada com base em Horton e Serafeim (2009).

$$
E R N_{i}^{I F R S-B R G A A P}=\alpha_{0}+\beta_{1} M V_{i}+\beta_{2} B T M_{i}+\beta_{3} A D R_{i}+\beta_{4} V O L_{i}+\beta_{5} B C G I_{i}+\sum_{j}^{j-1} \varphi_{j} \text { Ind }+\varepsilon
$$

Equação 47

onde $M V$ é o logaritmo do valor de mercado em $t$, calculado com base na quantidade e preço das ações em circulação; BTM corresponde à relação entre valor contábil do patrimônio líquido e seu valor de mercado; $A D R$, ou American Depositary Receipt, é uma dummy que recebe 1 quando a empresa é emissora de ADR e 0 caso contrário; VOL é uma dummy que 
assume 1 para casos de adoção voluntária e 0 caso contrário; BCGI é um índice de governança corporativa baseado em Lopes e Walker (2008); Ind corresponde a uma dummy para cada setor.

Os resíduos da equação 47 ( $R E R N$ ) refletem o componente não esperado, ou seja, aquilo que não foi previsto pelos analistas ou usuários da informação. A ideia é substituir os resíduos na equação 46, para avaliar a tempestividade do componente não esperado - RERN.

Além disso, pode-se calcular o componente não esperado pela diferença entre o lucro previsto para o ano da adoção inicial $\left(E P S_{i}\right)$ e o lucro ou prejuízo do mesmo período $\left(E R N_{i}\right)$. A diferença corresponde ao efeito surpresa (LOPES, 2010), presente na seguinte equação (informação verbal) $^{41}$.

$$
C A R_{-5+5}=\alpha_{0}+\beta_{1}\left(E R N_{i}-E P S_{i}\right)+\beta_{2} A D R_{i}+\beta_{3} V O L_{i}+\beta_{4} B C G I_{i}+\varepsilon
$$

Equação 48

onde $C A R_{-5+5}$ corresponde ao retorno anormal acumulado para uma janela de evento de 5 dias antes e após a data de divulgação das demonstrações contábeis de acordo com as normas internacionais; ERN refere-se ao resultado do exercício de acordo com as IFRS; EPS corresponde ao lucro por ação estimado por analistas de mercado; ADR, ou American Depositary Receipt, é uma dummy que recebe 1 quando a empresa é emissora de ADR e 0 caso contrário; VOL é uma dummy que assume 1 para casos de adoção voluntária e 0 caso contrário; BCGI é um índice de governança corporativa baseado em Lopes e Walker (2008); $\varepsilon$ é o erro aleatório do modelo.

Considerando que os analistas podem antecipar os números contábeis, enfraquecendo os modelos usados para analisar a oportunidade da contabilidade, pode-se utilizar a equação 48 para avaliar a tempestividade da informação contábil por meio do efeito surpresa.

Ainda pode-se comparar a relevância dos números contábeis full IFRS com o padrão anterior, BR GAAP de acordo com a Lei n ${ }^{\circ} 11.638 / 07$, por meio de uma adaptação nos modelos de Harris e Muller (1999) e Horton e Serafeim (2009):

\footnotetext{
${ }^{41}$ Informação fornecida pelo Prof. Alexsandro Broedel Lopes em 26 de agosto de 2010 durante aula.
} 


$$
\begin{aligned}
& P_{j}=\alpha_{0}+\alpha_{1} B V_{j}^{B R G A A P}+\alpha_{2} E R N_{j}^{B R G A A P}+\alpha_{3} B V_{j}^{I F R S-B R G A A P}+\alpha_{4} E R N_{j}^{I F R S-B R G A A P} \\
& +\alpha_{5} A D R_{i}+\alpha_{6} V^{\text {IOL }}+\alpha_{i} B C G I_{i}+\sum_{j}^{j-1} \varphi_{j} \text { Ind }+\varepsilon_{j}
\end{aligned}
$$

Equação 49

onde $P$ corresponde ao preço da ação $j ; B V^{B R G A A P}$ é o valor contábil do patrimônio líquido da empresa $j$ de acordo com o BRGAAP; $E R N^{B R G A A P}$ é o resultado do período da empresa $j$ de acordo com o BRGAAP; $B V^{I F R S-B R G A A P}$ é a diferença entre os patrimônios líquidos BRGAAP e IFRS para a empresa $j$; $E R N^{I F R S-B R G A A P}$ é a diferença entre os resultados BRGAAP e IFRS para a empresa $j$.

A constatação de coeficientes positivos para as variáveis $E^{B R G A A P}$ e $B V^{B R G A A P}$ indica que os números publicados de acordo com o BRGAAP refletem informação relevante. Após controlar os números em BRGAAP, os coeficientes para $E R N^{I F R S-B R G A A P}$ e $B V^{I F R S-B R G A A P}$ permitem analisar se as conciliações são avaliadas de forma incremental pelo mercado, isto é, se possuem poder explicativo adicional. Este modelo permite investigar se os números em IFRS e BRGAAP são avaliados de forma diferente pelo mercado por meio de análise comparativa dos coeficientes estimados.

Adicionalmente, pode-se comparar a associação relativa dos números em BRGAAP e IFRS com os valores das empresas, lembrando que associação relativa é uma das classificações dos estudos de value-relevance proposta por Holthausen e Watts (2001): estudos que analisam e comparam a relação entre o preço da ação e diferentes medidas de resultado. O objetivo destes testes é comparar os números contábeis em IFRS e BRGAAP, fornecendo evidências de quais estão mais fortemente relacionados com os valores de mercado, ou seja, quais são mais relevantes para o mercado.

\subsection{Aspectos Econométricos}

O objetivo desta subseção é descrever os principais aspectos econométricos das abordagens de dados em painel e diferenças em diferenças.

\subsubsection{Estimação dos modelos de dados em painel}


$\mathrm{Na}$ presença de variáveis omitidas, o método de dados em painel deve respeitar algumas premissas para gerar estimadores consistentes (WOOLDRIDGE, 2002). O autor (2002, p. 247) explica a situação problema por meio de um simples modelo linear:

$$
E(y \mid x, c)=\beta_{0}+x \beta+c
$$

Equação 50

onde $x$ representa o conjunto de variáveis aleatórias observáveis $\left(x_{1}, x_{2}, \ldots, x_{k}\right) ; c$ as variáveis aleatórias não observáveis; sendo que o interesse é estimar o vetor $\beta K X 1$. Se $c$ não é correlacionado $\operatorname{com} x_{j}$, então $c$ é apenas um fator não observável afetando $y$. No entanto, se $\operatorname{Cov}\left(x_{j}, c\right) \neq 0$ para $j, c$ pode trazer sérios problemas ao ser considerado no termo de erro. Sendo assim, sem informação adicional não é possível estimar $\beta$ de maneira consistente, muito menos determinar se há um problema. Porém, com dados amostrais em diferentes momentos no tempo, e assumindo algumas premissas em relação aos parâmetros da regressão, pode-se encontrar estimadores consistentes. Neste contexto, o efeito não observável $c$ ou variável latente pode ser tratado como um efeito aleatório ou fixo (WOOLDRIDGE, 2002). As principais abordagens para dados em painel são Pooled Ordinary Least Squares (POLS), efeitos fixos e efeitos aleatórios.

O estimador de POLS pode ser obtido a partir do seguinte modelo:

$$
y_{i t}=x_{i t} \beta+v_{i t}
$$

Equação 51

onde $t=1,2 \ldots, T ; v_{i t} \equiv c i+u_{i t}, t=1, \ldots, T$ são erros compostos; sendo que para cada $t, v_{i t}$ é a soma do efeito não observável e um erro idiossincrático. No entanto, as estimativas obtidas a partir da equação 51 são consistentes se $E\left(x_{i t}{ }^{\prime} v_{i t}\right)=0, t=1,2, \ldots, T$. Ou seja, não espera-se encontrar correlação entre $x_{i t}$ e $v_{i t}$, indicando que $E\left(x_{i t}{ }^{\prime} u_{i t}\right)=0$; e $E\left(x_{i t}{ }^{\prime} c_{i t}\right)=0, \quad t=1,2, \ldots, \quad T$ (WOOLDRIDGE, 2002).

No caso de efeitos aleatórios, a variável latente $c$ é considerada no termo de erro. Esta abordagem possui mais premissas em relação ao POLS, em destaque a exogeneidade forte em adição à ortogonalidade entre $c_{i}$ e $x_{i t}$. Além disso, pelo fato de tratar a correlação serial no erro 
composto, $v_{i t} \equiv c i+u_{i t}$, por meio de uma abordagem de Mínimos Quadrados Generalizados (MQG), o modelo de efeitos aleatórios pode ser mais eficiente em relação ao POLS. Neste sentido, o modelo pode ser definido como:

$$
y_{i t}=x_{i t} \beta+v_{i t}
$$

Equação 52

onde $E\left(v_{i t} \mid x_{i t}\right)=0, t=1,2, \ldots, T$, que atende à premissa de exogeneidade forte na equação 52 . Portanto, ao aplicar MQG e considerando $v_{i t} \equiv c_{i}+u_{i t}$, tem-se o seguinte modelo para todos os períodos $T$ :

$$
y_{i}=x_{i} \beta+v_{i}
$$

\section{Equação 53}

onde $v_{i}$ pode ser escrito como $v_{i}=c_{i} j_{T}+u_{i}$, sendo que $j_{T}$ é o vetor $T X 1$. A violação desta e de outras premissas pode causar o problema da heterocedasticidade ${ }^{42}$, tornando os estimadores não eficientes, mas ainda consistentes, portanto, permitindo inferências estatísticas. Uma alternativa a este problema é calcular o erro padrão robusto (WOOLDRIDGE, 2002).

$\mathrm{Na}$ abordagem de efeitos fixos o componente $c_{i}$ pode ser correlacionado com $x_{i t}$. Neste sentido, o modelo para efeitos fixos pode ser escrito como:

$$
y_{i}=x_{i} \beta+c_{i} j_{T}+u_{i}
$$

Equação 54

onde $j_{T}$ é o vetor $T X 1$. A equação 54 representa uma amostragem aleatória a partir do corte transversal. Uma das premissas é exogeneidade forte para as variáveis independentes condicionadas a $E\left(u_{i t} \mid x_{i}, c_{i}\right)=0, t=1,2, \ldots, T$. A principal diferença do efeito fixo em relação ao efeito aleatório deve-se a estimação consistente do efeito parcial na presença de variáveis omitidas constantes no tempo, as quais podem ser relacionados às variáveis observáveis $x_{i t}$. Portanto, o modelo de efeitos fixos pode ser mais robusto, porém, não permitindo a inclusão

\footnotetext{
${ }^{42}$ A forma básica de heterocedasticidade reflete a diferença entre indivíduos. No entanto, o problema da heterocedasticidade pode decorrer de um aumento na variância dos indivíduos ou empresas ao longo do período estudado - heterocedasticidade no tempo.
} 
de fatores constantes no tempo em $x_{i t}$. Wooldridge (2002) explica: se $c_{i}$ pode ser correlacionado com cada elemento de $x_{i t}$, não há maneira de diferenciar os efeitos das variáveis observáveis constantes no tempo daquelas não observáveis $c_{i}$.

Para decidir entre a especificação mais adequada (POOLS, efeitos fixos ou efeitos aleatórios), utilizam-se os testes de Chow, LM (Lagrange multiplier) de Breusch-Pagan e Hausman. Fávero et al (2009) explica que o teste de Chow pode ser usado para verificar se o modelo mais adequado é POLS ou efeitos fixos. Suas hipóteses são:

$\mathrm{H}_{0}$ : os interceptos são iguais para todas as cross-sections (POLS);

$\mathrm{H}_{1}$ : os interceptos são diferentes para todas as cross-sections (efeitos fixos).

Já o teste LM de Breusch-Pagan pode ser aplicado na avaliação dos resíduos de modelo estimado por Mínimos Quadrados Ordinários, permitindo verificar se a especificação mais adequada é POLS ou efeitos aleatórios. As hipóteses são:

$\mathrm{H}_{0}$ : a variância dos resíduos que refletem diferenças individuais é igual a zero (POLS);

$\mathrm{H}_{1}$ : a variância dos resíduos que refletem diferenças individuais é diferente de zero (efeitos aleatórios).

E, por fim, o teste de Hausman que contribui na decisão entre efeitos fixos e aleatórios. Suas hipóteses são:

$\mathrm{H}_{0}$ : o modelo de correção de erros é adequado (efeitos aleatórios);

$\mathrm{H}_{1}$ : o modelo de correção de erros não é adequado (efeitos fixos).

Considerando a possibilidade de violação de algumas premissas dos modelos, gerando um estimador inadequado devido aos problemas de correlação serial e heterocedasticidade, podese aplicar o estimador da matriz de variância robusta, dado por:

$$
\operatorname{Ava} \hat{r}\left(\hat{\beta}_{F E}\right)=\left(\ddot{X}^{\prime} \ddot{X}\right)^{-1}\left(\sum_{i=1}^{N} \ddot{X}_{i}^{\prime} \hat{u}_{i} \hat{u}_{i}^{\prime} \ddot{X}_{i}\right)\left(X^{\prime} X\right)^{-1}
$$


que foi sugerido por Arellano (1987) e seguido por White (1984). A matriz de variância robusta é válida na presença de heterocedasticidade ou correlação serial, dado que $T$ é pequeno em relação a $N$ (WOOLDRIDGE, 2002).

No contexto de dados em painel, deve-se atentar ainda às propriedades das séries temporais, sendo que os principais problemas que devem ser observados são regressão espúria, não estacionariedade e autocorrelação serial. Segundo Gujarati (2006), a estacionariedade é observada quando a média, a variância e autocovariância não variam com o tempo, possibilitando a realização de inferências sobre uma população. No entanto, o autor argumenta que a verificação de não estacionariedade de uma série temporal implica na impossibilidade de usar o modelo para fazer previsões, pois o mesmo é válido para um episódio específico. Consequentemente, as relações observadas entre as variáveis dependentes e independentes podem ser coerentes para o período em estudo. A validade da análise dos resultados da regressão a partir de duas ou mais séries não estacionárias pode ser investigada a partir dos testes de co-integração. Os testes de co-integração são recomendados para evitar situações de regressão espúria.

Neste sentido, Iquapaza, Barbosa e Bressan (2004) ressaltam que a não estacionariedade pode levar ao problema da regressão espúria e invalidar a inferência estatística, sendo que os testes de raiz unitária Dickey-Fuller e Phillips-Perron são adequados para avaliar o problema em questão.

\subsubsection{Modelo de Diferenças em Diferenças}

O modelo de Diferenças em Diferenças (DD) é comumente usado para avaliar políticas públicas ou o efeito de uma Lei sobre determinada variável de interesse, e ainda considera o problema das variáveis não observáveis. Angrist e Pischke (2009) explicam que a estratégia de efeitos fixos exige a abordagem de dados em painel, pois a variável independente de interesse pode variar apenas em função do grupo a que pertence. Neste sentido, as variáveis omitidas dos grupos podem ser capturadas pelos efeitos fixos dos grupos, uma abordagem que conduz a estratégia de DD. 
Logicamente não podemos afirmar que a mudança da variável de interesse deve-se a um evento específico, como a aplicação de uma Lei, pois outros fatores (variáveis omitidas) podem influenciar a variável investigada. Neste sentido, faz-se necessário dividir as empresas estudadas em dois grupos: o grupo de tratamento e o grupo de controle; enquanto o primeiro grupo é formado pelas empresas suscetíveis à Lei, o segundo não o é. Assim, ambos estarão sujeitos ao efeito das variáveis não observáveis, permitindo avaliar o efeito adicional proporcionado pela variável de interesse a partir de uma comparação entre os dois grupos.

Wooldridge (2002, p. 130) formaliza o modelo definindo o grupo de controle como $A$ e o grupo de tratamento como $B ; d B$ é uma dummy que assume 1 quando a observação pertence ao grupo de tratamento e 0 caso contrário. Além disso, $d 2$ é outra variável dummy para indicar o período de aplicação da política investigada. Assim o modelo pode ser definido como:

$$
y=\beta_{0}+\delta_{0} d 2+\beta_{1} d B+\delta_{1} d 2 \times d B+u
$$

Equação 56

onde y é a variável de interesse; enquanto a dummy de período $d 2$ captura os fatores que afetam $y$ ao longo do período, a variável $d B$ permite diferenciar os dois grupos analisados. $\mathrm{O}$ coeficiente de interesse é $\delta_{1}$, sendo obtido a partir da interação entre $d 2$ e $d B$, representando simplesmente uma dummy para as observações presentes no grupo de controle durante o período da política. Além disso, para que os estimadores DD não sejam viesados exige-se que a mudança na política não seja relacionada sistematicamente com outros fatores que afetam $y$ (WOOLDRIDGE, 2002).

Definindo $y_{1}$ como o resultado do tratamento e $y_{0}$ sem o tratamento, o efeito do tratamento médio ou Average Treatment Effect (ATE) é dado por $A T E \equiv E\left(y_{1}-y_{0}\right)$. Um indicador de tratamento binário $w$ assume 1 para caso de tratamento e 0 caso contrário. Assim, $y_{0}, y_{1}$ e $w$ representam um vetor aleatório da população de interesse, permitindo definir o efeito médio do tratamento sobre o grupo de tratamento, ou ainda Average Treatment Effect on the Treated - $\left(A T E_{1}\right): A T E_{1} \equiv E\left(y_{1}-y_{0} \mid w=1\right)$. O efeito médio daqueles que realmente participaram do programa é dado por $A T E_{1}$, que pode ser visualizado de forma mais clara na seguinte equação: 


$$
y=(1-w) y_{0}+w y_{1}=y_{0}+w\left(y_{1}-y_{0}\right)
$$

Equação 57

As premissas deste modelo consideram que a amostra é independente e identicamente distribuída (i.i.d.) a partir de uma população. No entanto, na ausência de aleatorização pode-se adicionar variáveis de controle $x$ para eliminar a endogeneidade. Essa alternativa baseia-se na ignorabilidade de tratamento, dada por ATE.1': $E\left(y_{0} \mid x, w\right)=E\left(y_{0} \mid x\right)$; e $E\left(y_{l} \mid x, w\right)=E\left(y_{l} \mid x\right)$. A ideia básica de ATE.1'é explicada por Wooldridge (2002): se é possível observar informação suficiente (por meio de $x$ ) que determine o tratamento, então $\left(y_{0}, y_{1}\right)$ pode ser independente de $w$, condicional à $x$. Neste caso, assume-se que todas as variáveis de controle são adicionadas no modelo, eliminando ou reduzindo o viés, além de reduzir o problema da endogeneidade.

Considerando que a hipótese ATE.1'é forte, pode-se questionar a validade das estimativas de um modelo DD. No entanto, Bertrand et al (2004) apresentam algumas soluções diante dos problemas que aparecem na operacionalização de um modelo de tratamento. Uma correção é voltada para o problema da correlação serial (espaço e tempo), que parte da eliminação do conjunto de dados para os anos anterior e posterior à aplicação da Lei.

O modelo de tratamento aplicado a esta tese implica na definição dos grupos de tratamento e controle. Conforme comentado anteriormente, o grupo de tratamento refere-se às empresas que adotaram as IFRS obrigatoriamente a partir de 2010, enquanto o grupo de controle é formado pelas empresas que adotaram as IFRS voluntariamente. A variável de interesse é dada pelo efeito das normas internacionais no custo de capital próprio das empresas que adotaram as IFRS obrigatoriamente, conforme equação 15. Graficamente tem-se: 


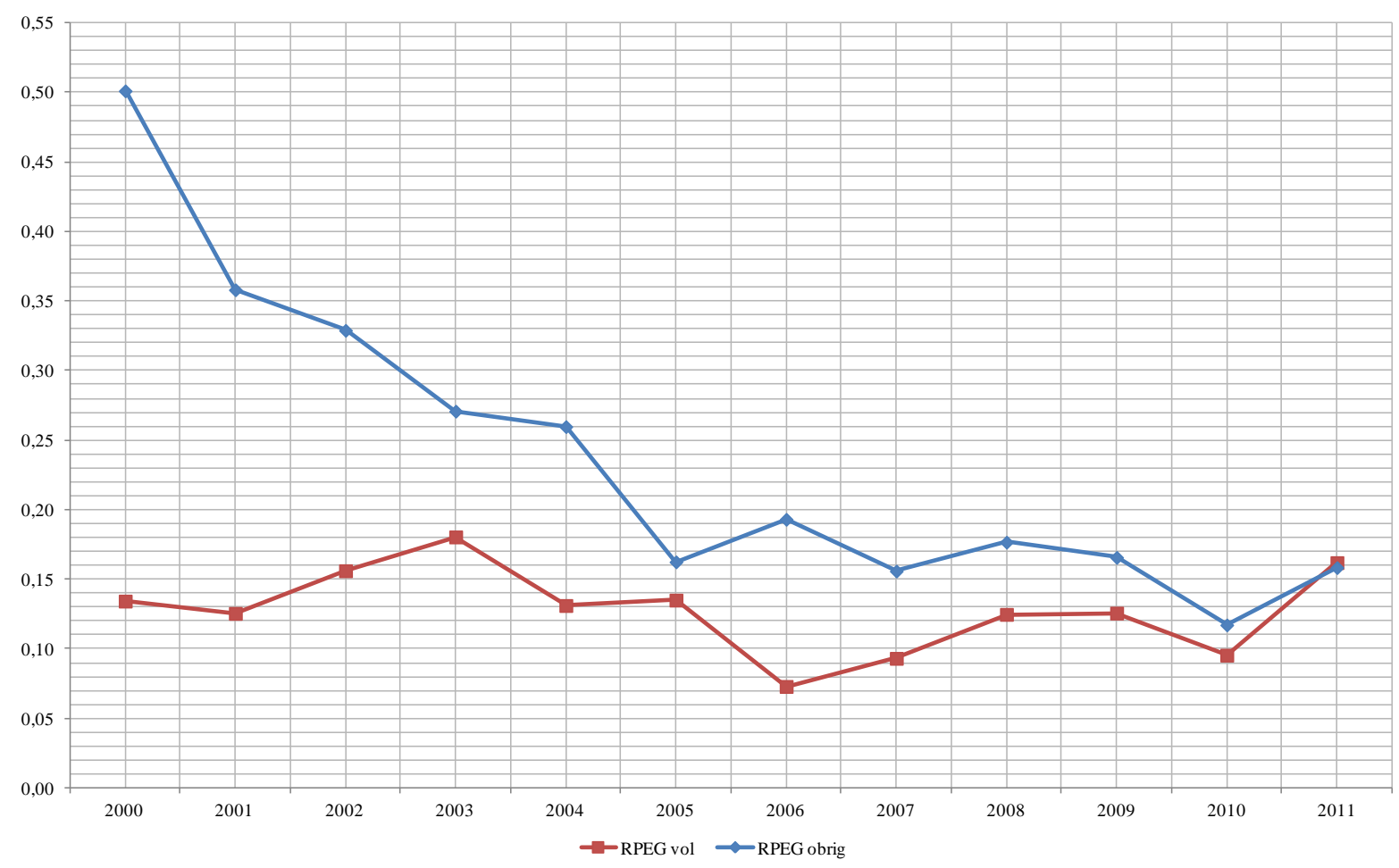

Gráfico 1 - Comportamento do custo de capital próprio médio $\left(R_{\mathrm{PEG}}\right)$ para os grupos de controle (empresas que adotaram IFRS antecipadamente) e tratamento (empresas que adotaram IFRS obrigatoriamente) no período 2000-2011.

Observando o gráfico pode-se observar uma redução no custo de capital próprio para os dois grupos, seguida de uma reversão em 2011. O custo de capital próprio médio para as empresas que adotaram as IFRS voluntariamente é de 0,0954 e 0,16199 em 2010 e 2011 respectivamente. No grupo de tratamento os números são de 0,1172 e 0,1584. Estes números revelam que as empresas que adotaram as IFRS obrigatoriamente possuem um custo de capital maior em 2010, comparativamente ao grupo de controle, um comportamento também observado ao longo de 2000-2009. Particularmente, este resultado não revela surpresas, dado que as empresas que anteciparam as IFRS tiveram alguma motivação para fazê-lo, implicando em benefícios para a empresa. Porém, em 2011 ocorre uma inversão, visto que as empresas do grupo de tratamento passaram a apresentar um custo de capital menor.

Ainda analisando o gráfico 1, o processo de convergência dado pela adoção completa das IFRS em 2010 e 2011 não revela de forma clara uma redução no custo de capital, pois apesar de haver uma redução em 2010 para o grupo tratamento, o mesmo ocorre com o grupo de controle. Portanto, para o período de adoção obrigatória não é possível visualizar a tendência do custo de capital para o grupo de tratamento. 


\subsection{Brazilian Corporate Governance Index - BCGI}

Um índice de governança corporativa, denominado Brazilian Corporate Governance Index BCGI validado por outros trabalhos (DALMÁCIO, 2009; LIMA, 2010) foi desenvolvido com base em Lopes e Walker (2008). O objetivo é investigar o efeito das práticas de governança corporativa na qualidade da informação contábil das empresas brasileiras de capital aberto, pois há indícios na literatura (LOPES; WALKER, 2008; GABRIEL, 2011) de tal relação. Os itens que compõem o check-list estão presentes no anexo. 


\section{ANÁLISE DOS RESULTADOS}

Esta seção foi dividida em 8 partes: i) análise do custo de capital próprio das empresas que compõem a amostra pelo modelo de diferenças em diferenças; ii) análise do gerenciamento de resultados; iii) análise do conservadorismo condicional; iv) análise da relevância da informação contábil; v) análise da tempestividade; vi) estudo de evento; vii) relação entre earnings quality e custo de capital próprio; e viii) testes de robustez.

Destaca-se que os testes de especificação dos modelos apresentados na seção 3.4 foram devidamente aplicados ao longo dos testes, e no caso de violações das premissas, o estimador da matriz de variância robusta foi calculado com base na equação 55.

\subsection{Análise do Custo de Capital Próprio pelo Modelo de Diferenças em Diferenças}

A estatística descritiva para as variáveis que compõem a equação 15 pode ser observada na tabela seguinte.

Tabela 5 - Estatística descritiva das variáveis $r_{P E G}, S I Z E, R E T V A R, L E V, A D R$ e BCGI para o período 2000-2011

\begin{tabular}{c|cc|cc|cc|cc|cc|cc}
\hline & \multicolumn{2}{|c|}{$r_{P E G}$} & \multicolumn{2}{c|}{ SIZE } & \multicolumn{2}{c|}{ RETVAR } & \multicolumn{2}{c|}{$L E V$} & \multicolumn{2}{c|}{ ADR } & \multicolumn{2}{c}{$B C G I$} \\
\hline$t$ & $\mu$ & $\sigma$ & $\mu$ & $\sigma$ & $\mu$ & $\sigma$ & $\mu$ & $\sigma$ & $\mu$ & $\sigma$ & $\mu$ & $\sigma$ \\
\hline 2000 & 0,239 & 0,296 & 21,885 & 1,523 & 13,786 & 5,280 & 0,345 & 0,201 & 0,129 & 0,337 & 0,212 & 0,187 \\
\hline 2001 & 0,220 & 0,262 & 21,911 & 1,814 & 14,459 & 5,180 & 0,364 & 0,190 & 0,151 & 0,360 & 0,223 & 0,191 \\
\hline 2002 & 0,214 & 0,229 & 22,026 & 1,840 & 12,689 & 6,830 & 0,394 & 0,191 & 0,172 & 0,379 & 0,249 & 0,210 \\
\hline 2003 & 0,226 & 0,195 & 21,894 & 1,905 & 12,766 & 5,558 & 0,351 & 0,173 & 0,172 & 0,379 & 0,264 & 0,204 \\
\hline 2004 & 0,195 & 0,159 & 21,930 & 1,857 & 11,166 & 4,813 & 0,308 & 0,162 & 0,194 & 0,397 & 0,306 & 0,217 \\
\hline 2005 & 0,148 & 0,132 & 21,760 & 2,319 & 12,222 & 7,267 & 0,273 & 0,152 & 0,194 & 0,397 & 0,353 & 0,205 \\
\hline 2006 & 0,147 & 0,138 & 21,822 & 2,286 & 10,167 & 3,580 & 0,265 & 0,167 & 0,215 & 0,413 & 0,448 & 0,179 \\
\hline 2007 & 0,128 & 0,100 & 22,254 & 1,473 & 9,928 & 4,463 & 0,244 & 0,157 & 0,237 & 0,427 & 0,515 & 0,147 \\
\hline 2008 & 0,154 & 0,119 & 22,499 & 1,467 & 15,846 & 7,108 & 0,300 & 0,182 & 0,247 & 0,434 & 0,541 & 0,130 \\
\hline 2009 & 0,150 & 0,107 & 22,663 & 1,429 & 13,388 & 7,648 & 0,290 & 0,181 & 0,247 & 0,434 & 0,550 & 0,141 \\
\hline 2010 & 0,110 & 0,066 & 22,871 & 1,370 & 8,381 & 2,673 & 0,277 & 0,145 & 0,258 & 0,440 & 0,636 & 0,126 \\
\hline 2011 & 0,160 & 0,087 & 22,997 & 1,352 & 8,957 & 3,477 & 0,305 & 0,156 & 0,269 & 0,446 & 0,640 & 0,128 \\
\hline
\end{tabular}

Nota: $\mu$ e $\sigma$ são média e desvio padrão das variáveis; $r_{P E G}$ é o custo de capital estimado por meio do modelo Price Earnings Growth - PEG; ADR, ou American Depositary Receipt, é uma dummy que recebe 1 quando a empresa é emissora de $A D R$ e 0 caso contrário; SIZE é o logaritmo natural do ativo total; RETVAR é o desvio padrão dos retornos mensais das ações para um ano; $L E V$ é dado pela relação entre dívida total e ativo total; e $B C G I$ é um índice de governança corporativa apresentado na seção 3.5 .

A tabela 5 revela que, em média, o custo de capital das empresas presentes na amostra diminuiu até 2010, exceto por 2008 e 2009, período no qual se observou um aumento no $r_{P E G}$. 
Este aumento pode ser explicado pela Crise Financeira de 2008, que teve origem no mercado imobiliário norte-americano, após a explosão da bolha especulativa no mercado de hipotecas subprime. Esta crise atingiu fortemente os mercados financeiros e de capitais nos países da Europa, além dos mercados emergentes, sensíveis aos movimentos internacionais. Analisando o comportamento do IBOVESPA ${ }^{43}$, percebe-se que o índice começou a cair acentuadamente próximo a julho de 2008 e se recuperou em torno de maio de 2009, período associado a uma redução do investimento estrangeiro no mercado brasileiro, explicado pela corrida de investidores para posições de menor risco. Os analistas de mercado incorporaram em suas estimativas de Earnings Per Share (EPS) os efeitos da Crise Financeira de 2008, explicando as alterações no $R_{P E G}$. No entanto, em 2010 nota-se uma redução no custo de capital médio das empresas, impulsionado, principalmente, pela desintensificação dos efeitos da crise, acompanhado por uma recuperação da economia brasileira.

Os efeitos da Crise Financeira também podem ser percebidos na variável RETVAR, uma proxy para a volatilidade dos papéis, que apresentou a maior média em 2008, que corresponde ao auge da crise.

A tabela 5 ainda revela um resultado interessante no que diz respeito às práticas de Governança Corporativa no mercado brasileiro. Nota-se que ao longo do período estudado há um aumento no BCGI, um índice que reflete algumas práticas de Governança Corporativa. Este crescimento é explicado por transformações sociais, econômicas e políticas que passaram a mudar o cenário nacional, culminando no fortalecimento de práticas de governança corporativa, tais como a Nova Lei das S.A., o desenvolvimento dos códigos de governança corporativa, a criação dos níveis de governança corporativa da BM\&FBOVESPA (SILVEIRA, 2004).

Em seguida, a correlação entre as variáveis é analisada pelos coeficientes de Pearson.

\footnotetext{
${ }^{43}$ Disponível em <http://www.bmfbovespa.com.br/home.aspx?idioma=pt-br>.
} 
Tabela 6 - Correlação entre as variáveis $r_{P E G}, S I Z E$, RETVAR e LEV .

Nota: coeficientes de correlação de Pearson. * coeficiente significante estatisticamente a 0,05.

Uma análise da tabela 6 revela uma fraca e positiva correlação entre $r_{P E G}$ e as variáveis SIZE $e$ RETVAR. O coeficiente de correlação para $L E V$ não foi significante estatisticamente. O maior coeficiente de correlação observado foi obtido entre as variáveis RETVAR e SIZE, revelando uma associação negativa entre tamanho e volatilidade, ou seja, quanto maior a empresa menor a volatilidade dos papéis.

A equação 15 tem por objetivo investigar o efeito da adoção obrigatória das IFRS no custo de capital próprio das empresas que compõem a amostra. Após os devidos testes de especificação e correção de White, os seguintes resultados foram obtidos: 
Tabela 7 - Estimativas geradas para a equação 15 - custo de capital próprio pelo modelo de diferenças em diferenças

\begin{tabular}{|c|c|c|}
\hline \multicolumn{3}{|c|}{$\begin{array}{l}r_{P E G_{i t}}=\alpha_{0}+\alpha_{1} * \text { ado tan tes obrigatórios IFRS }+\alpha_{2} * \text { período pós adoção } \\
+\alpha_{3} * \text { ado tantes obrigatórios IFRS * período pós adoção }+\alpha_{4} * A D R_{i t}+ \\
+\alpha_{5} * B C G I_{i t}+\alpha_{6} * \operatorname{SIZE}_{i t}+\alpha_{7} * R_{E T V A R}+\alpha_{8} * L E V_{i t}+\sum_{j}^{j-1} \varphi_{j} I n d+\varepsilon_{i t}\end{array}$} \\
\hline Variáveis & Coeficientes & $\mathbf{T}$ \\
\hline C & 0,3013 & $1,71 * * *$ \\
\hline SIZE & $-0,0026$ & $-0,39$ \\
\hline$R E T V A R$ & 0,0028 & 1,60 \\
\hline$L E V$ & $-0,1403$ & $-2,45 * *$ \\
\hline$A D R$ & 0,0104 & 0,56 \\
\hline$B C G I$ & $-0,1600$ & $-3,59 *$ \\
\hline $\begin{array}{l}\text { Adotantes } \\
\text { obrigatórios } \\
\text { IFRS }\end{array}$ & 0,0667 & $3,14^{*}$ \\
\hline $\begin{array}{l}\text { Período pós } \\
\text { adoção }\end{array}$ & 0,0600 & $2,44 * *$ \\
\hline
\end{tabular}

Adotantes

obrigatórios

IFRS $x$ Período

$-0,0741$

$-4,80 *$

pós adoção

\begin{tabular}{lc}
\hline Indústria & Sim \\
\hline $\mathrm{N}$. Obs. & 424 \\
\hline $\mathrm{R}^{2}$ ajust. & 0,15 \\
\hline Estatística $\mathrm{F}$ & $4,16^{*}$
\end{tabular}

Nota: A variável "adotantes obrigatórios IFRS” é uma dummy que assume 1 quando a empresa adotou IFRS obrigatoriamente e 0 caso contrário. Ela revela a diferença em termos de custo de capital entre os dois grupos (adoção obrigatória versus adoção voluntária). A variável "período pós adoção" é uma dummy que recebe 1 para o período de adoção completa (2010 e 2011). Ela mostra a tendência de aumento ou diminuição de custo de capital, ou seja, é um efeito temporal. A variável "adotantes obrigatórios IFRS x período pós adoção" é fruto da multiplicação das dummies anteriores e revela o verdadeiro impacto da adoção obrigatória no custo de capital, controlando o efeito temporal. Coeficientes *, ** e *** são significantes estatisticamente a nível de 0,01, 0,05 e 0,10 respectivamente.

A variável de interesse, Adotantes obrigatórios IFRS x Período pós-adoção, é significante estatisticamente e apresenta sinal negativo, sugerindo uma redução no custo de capital próprio em torno de 7 pontos-base para as empresas no período da adoção completa. Esse resultado sugere a aceitação da hipótese de pesquisa de custo de capital próprio, ou seja, o custo de capital próprio das empresas que adotaram obrigatoriamente as IFRS no período 2010 e 2011 é menor em relação ao grupo de controle, coerente com Li (2010) e Lee, Walker e Christensen (2010). No cenário nacional, este resultado reforça os achados de Lima (2011), que investigou a adoção parcial das IFRS e encontrou fracos indícios de redução do custo de 
capital próprio. Logo, o estudo do custo de capital próprio no processo de convergência às IFRS mostra-se esclarecedor no período da adoção completa.

Além disso, pode-se investigar o efeito da variável de interesse "Adotantes obrigatórios IFRS $x$ Período pós-adoção" diante da qualidade do serviço de auditoria. Assumindo que as 4 maiores empresas de auditoria, PricewaterhouseCoopers, Deloitte Touche Tohmatsu, KPMG e Ernst \& Young prestem um serviço de maior qualidade em relação aos seus pares, espera-se que o mercado atribua maior credibilidade às demonstrações contábeis das 4 grandes, culminando em menor assimetria de informações e, consequentemente, menor custo de capital. Para avaliar este aspecto, uma simples interação entre as variáveis "Adotantes obrigatórios IFRS x Período pós-adoção" e Auditoria, uma dummy para as 4 maiores empresas de auditoria, é suficiente. Ao estimar o coeficiente para esta variável interativa, observa-se uma redução em torno de 11 pontos-base, permitindo afirmar que a auditoria implica em maior redução do custo de capital no período da adoção obrigatória. Este resultado mostra-se interessante para as empresas que buscam redução de custo de capital, pois representa um incentivo para a contratação dos serviços das 4 grandes empresas de auditoria.

A variável BCGI (tabela 7) apresenta sinal negativo, indicando que as práticas de governança corporativa contribuem para reduzir o custo de capital próprio das empresas, coerente com Lopes (2008). As práticas de governança corporativa englobam mecanismos para sinalizar maior transparência e igualdade nos direitos dos proprietários, resultando em menor risco de expropriação para os acionistas não majoritários. As empresas que buscam recursos no mercado de capitais podem se comprometer com práticas superiores de governança corporativa, com o propósito de reduzir os custos de agência e o problema da assimetria informacional. Neste contexto, o maior comprometimento das empresas pode ser recompensando por um menor custo de capital próprio.

\subsection{Análise do Gerenciamento de Resultados}

Esta subseção pode ser dividida em 4 partes: i) Gerenciamento de Resultados (GR) segundo o modelo de Barth et al (2006) dado pela equação 17, ii) GR segundo TEOH; iii) GR de acordo com JM; iv) GR segundo KS; e v) análise do GR no período da adoção completa das IFRS com base no modelo adaptado de Tendeloo e Vanstraelen (2005). 


\subsubsection{Gerenciamento de Resultados segundo Barth et al (2006)}

A estatística descritiva das principais variáveis do modelo pode ser observada na tabela 8 .

Tabela 8 - Estatística descritiva das variáveis $\triangle N I$, MVE, GROWTH, EISSUE, DEBT, DISSUE e TURN para o período 2000-2011

\begin{tabular}{|c|c|c|c|c|c|c|c|c|c|c|c|c|c|c|}
\hline \multirow[b]{2}{*}{$t$} & \multicolumn{2}{|c|}{$\Delta N I$} & \multicolumn{2}{|c|}{$M V E$} & \multicolumn{2}{|c|}{ GROWTH } & \multicolumn{2}{|c|}{ EISSUE } & \multicolumn{2}{|c|}{$D E B T$} & \multicolumn{2}{|c|}{ DISSUE } & \multicolumn{2}{|c|}{ TURN } \\
\hline & $\mu$ & $\sigma$ & $\mu$ & $\sigma$ & $\mu$ & $\sigma$ & $\mu$ & $\sigma$ & $\mu$ & $\sigma$ & $\mu$ & $\sigma$ & $\mu$ & $\sigma$ \\
\hline 2000 & 0,01 & 0,09 & 23,96 & 3,93 & 0,27 & 0,43 & 3,08 & 21,75 & 0,75 & 2,65 & 0,36 & 0,86 & 0,43 & 0,41 \\
\hline 2001 & 0,01 & 0,07 & 24,20 & 3,79 & 0,24 & 0,47 & 0,34 & 2,41 & $-0,07$ & 8,83 & 0,41 & 0,69 & 0,46 & 0,41 \\
\hline 2002 & $-0,02$ & 0,08 & 24,07 & 3,76 & 0,50 & 1,17 & 0,08 & 0,33 & 3,51 & 11,26 & 0,47 & 0,88 & 0,49 & 0,41 \\
\hline 2003 & 0,06 & 0,10 & 24,81 & 3,79 & 0,21 & 0,21 & 0,37 & 2,59 & 3,43 & 15,18 & 0,01 & 0,49 & 0,53 & 0,46 \\
\hline 2004 & 0,04 & 0,06 & 23,55 & 3,61 & 0,33 & 0,47 & 52,69 & 420,48 & 8,10 & 57,76 & 0,33 & 2,24 & 0,62 & 0,54 \\
\hline 2005 & 0,02 & 0,05 & 22,96 & 3,24 & 0,18 & 0,33 & 0,24 & 1,16 & 0,89 & 1,50 & 0,11 & 0,47 & 0,63 & 0,51 \\
\hline 2006 & 0,01 & 0,04 & 23,01 & 3,28 & 0,31 & 0,62 & 2,13 & 7,94 & 1,64 & 4,97 & 0,93 & 3,03 & 0,54 & 0,45 \\
\hline 2007 & 0,02 & 0,04 & 22,01 & 1,79 & 0,66 & 2,64 & 16,31 & 118,05 & 0,37 & 4,07 & 11,23 & 91,03 & 0,62 & 0,45 \\
\hline 2008 & $-0,01$ & 0,10 & 21,31 & 1,70 & 0,47 & 0,84 & 2,24 & 12,93 & 0,93 & 2,87 & 10,03 & 78,53 & 0,66 & 0,51 \\
\hline 2009 & 0,03 & 0,10 & 22,32 & 1,37 & 0,25 & 0,86 & 1,57 & 10,48 & 0,94 & 1,51 & 0,33 & 1,00 & 0,66 & 0,50 \\
\hline 2010 & 0,02 & 0,04 & 22,55 & 1,24 & 0,26 & 0,32 & 0,27 & 0,72 & 1,00 & 1,39 & 0,44 & 0,99 & 0,65 & 0,48 \\
\hline 2011 & $-0,01$ & 0,05 & 22,49 & 1,35 & 0,15 & 0,25 & 0,35 & 1,26 & 0,87 & 2,17 & 0,54 & 2,79 & 0,65 & 0,50 \\
\hline
\end{tabular}

Nota: $\triangle N I$ corresponde ao lucro em $t$ menos o lucro em $t$ - 1 , esta diferença dividida pelo ativo total; $M V E$ é o logaritmo natural do valor de mercado do patrimônio líquido no final do ano; GROWTH é a porcentagem de mudanças nas vendas; EISSUE é uma mudança percentual na quantidade de ações ordinárias; DEBT é o total de dívidas dividido pelo total do patrimônio líquido no final do ano; DISSUE é a mudança percentual no total de dívidas; TURN é a receita dividida pelo total de ativos no final do ano.

A variação média do lucro em 2002 e 2008 é negativa, coerente com a desvalorização da taxa de câmbio em 2002 e a Crise Financeira de 2008. De maneira geral, as duas crises econômicas (COSTA; REIS; TEIXEIRA, 2012) influenciaram negativamente os números contábeis das empresas brasileiras. Em 2010, primeiro ano da adoção completa das IFRS, a variação média do lucro é positiva, sendo que o desvio-padrão é baixo em relação aos outros anos, indicando uma menor dispersão dos dados. Porém, no segundo ano da adoção completa, observa-se uma redução na variação média do lucro.

No que diz respeito à análise de correlação, a tabela 9 revela os coeficientes de correlação de Pearson. 
Tabela 9 - correlação entre as variáveis $\triangle N I$, MVE, GROWTH, EISSUE, DEBT, DISSUE e TURN

\begin{tabular}{c|c|c|c|c|c|c|c|c}
\hline & $\Delta N I$ & $M V E$ & GROWTH & EISSUE & DEBT & DISSUE & TURN & $C F$ \\
\hline$\Delta N I$ & & 0,0301 & $0,0867^{*}$ & $0,1321^{*}$ & 0,0079 & $-0,0018$ & $0,0903^{*}$ & 0,0057 \\
\hline$M V E$ & & & $-0,0893^{*}$ & $-0,0234$ & $-0,0536$ & $-0,0453$ & $-0,2105^{*}$ & $0,3321^{*}$ \\
\hline GROWTH & & & & $0,2927^{*}$ & $-0,0130$ & 0,0239 & $-0,0533$ & $-0,0509$ \\
\hline EISSUE & & & & & 0,0029 & $-0,0006$ & $-0,0404$ & $-0,0100$ \\
\hline DEBT & & & & & & $-0,0030$ & 0,0007 & $-0,0300$ \\
\hline DISSUE & & & & & & & $-0,0267$ & $-0,0447$ \\
\hline$T U R N$ & & & & & & & & $-0,0568$ \\
\hline$C F$ & & & & & & & &
\end{tabular}

Nota: coeficientes de correlação de Pearson. * coeficiente significante estatisticamente a 0,05.

Entre os coeficientes de correlação estimados as variáveis $M V E$ e $C F$ apresentaram a maior associação, indicando uma relação positiva entre valor de mercado e fluxo de caixa. Além disso, encontra-se uma correlação baixa ${ }^{44}$ e positiva entre as variáveis TURN e $\triangle N I$.

A estimação da equação 17 gerou os seguintes resultados:

\footnotetext{
${ }^{44}$ Para esta tese adotou-se: a correlação forte é obtida para coeficientes entre 0,70 e 1 ; moderada entre 0,3 e 0,7 ; e fraca entre 0 e 0,3.
} 
Tabela 10 Estimativas geradas para o modelo adaptado de Barth et al (2006)

\begin{tabular}{|c|c|c|}
\hline \multicolumn{3}{|c|}{ 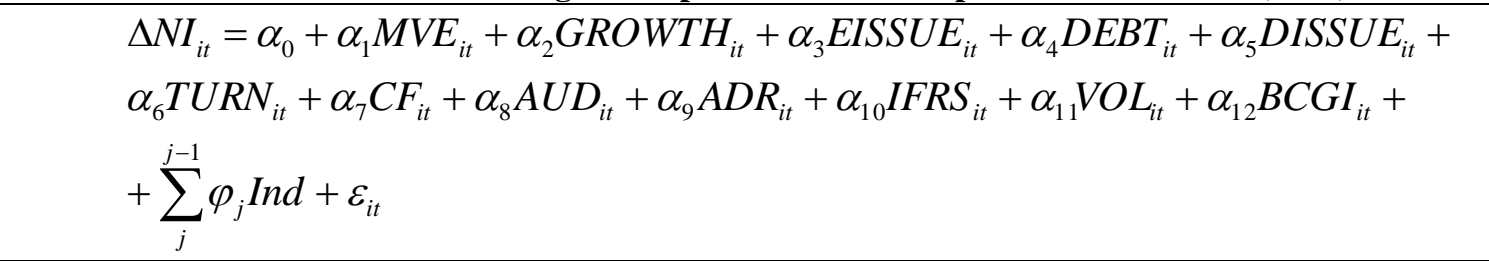 } \\
\hline Variáveis & Coeficientes & $\mathbf{t}$ \\
\hline$C$ & $-0,1222$ & $-2,98 *$ \\
\hline$M V E$ & 0,0022 & $1,84 * * *$ \\
\hline GROWTH & 0,0111 & $6,23 *$ \\
\hline EISSUE & $-0,0000$ & $-0,11$ \\
\hline$D E B T$ & 0,0034 & $3,01^{*}$ \\
\hline DISSUE & $-0,0000$ & $-1,38$ \\
\hline$T U R N$ & 0,0213 & $2,53 * *$ \\
\hline$C F$ & 0,0045 & $3,60 *$ \\
\hline$A D R$ & $-0,0139$ & $-1,97 * *$ \\
\hline$V O L$ & $-0,0030$ & $-0,29$ \\
\hline$A U D$ & 0,0109 & $1,94 * * *$ \\
\hline IFRS & $-0,0092$ & $-2,20 * *$ \\
\hline$B C G I$ & $-0,0281$ & $-1,31$ \\
\hline Indústria & Sim & \\
\hline N. Obs. & 480 & \\
\hline $\mathrm{R}^{2}$ ajust. & 0,08 & \\
\hline Estatística F & $2,49 *$ & \\
\hline
\end{tabular}

Barth et al (2006) e Lang, Raedy e Wilson (2006) explicam a lógica do modelo: ao estimá-lo pretende-se separar os dois componentes (natural e discricionário) que influenciam o lucro. Para isso, regride-se o lucro a partir de fatores intrínsecos ao negócio, tais como, MVE, GROWTH etc. Assumindo que os resíduos podem representar a discricionariedade exercida pela administração, a baixa variância dos resíduos gerados pela regressão, pode ser considerada um indicador de práticas de gerenciamento de resultado voltadas para a suavização do resultado.

O gráfico a seguir mostra o comportamento da variância dos resíduos ao longo do período 2000-2011. 


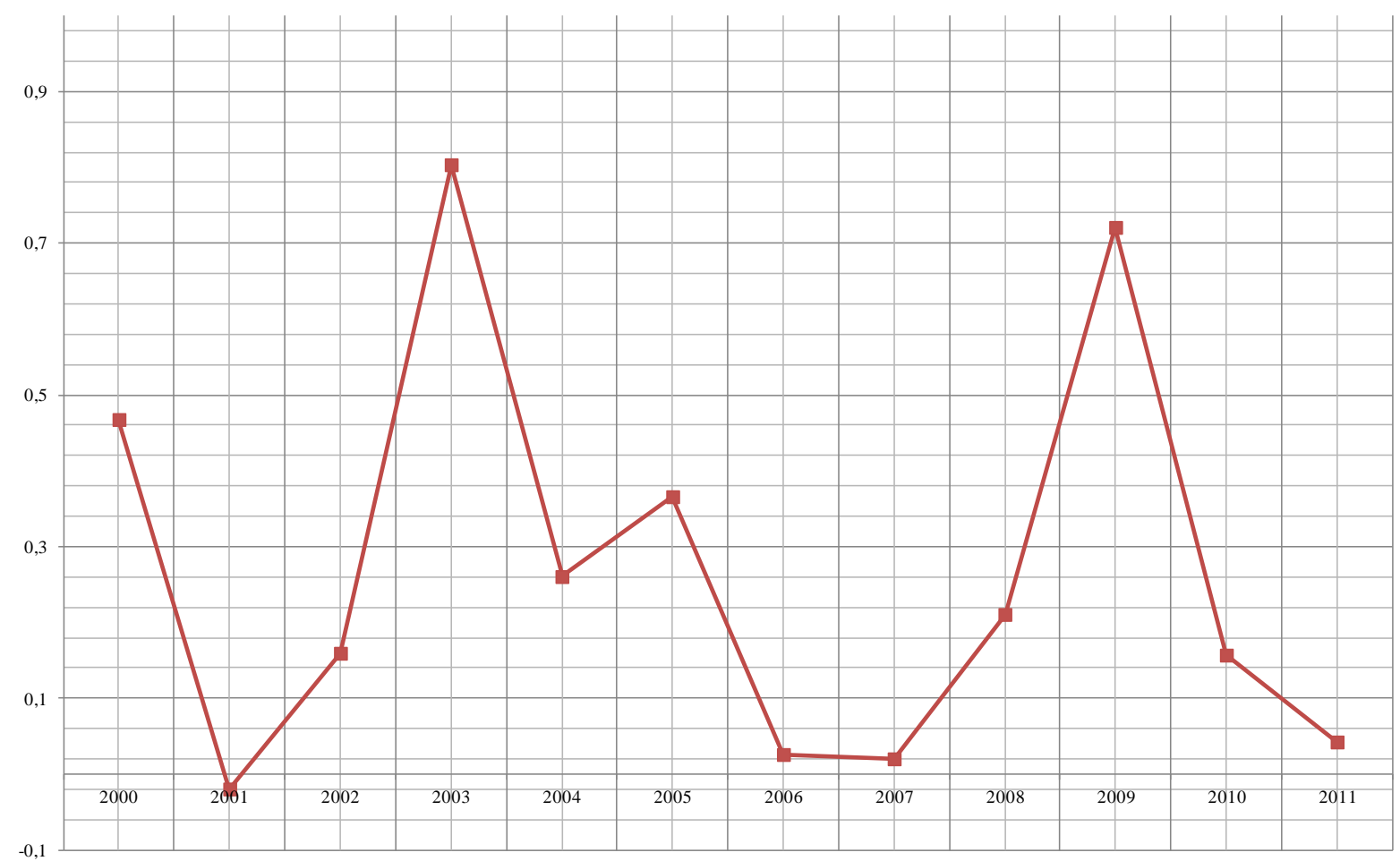

Gráfico 2 - Variância dos resíduos gerados pela equação 39

Nota: a variância dos resíduos foi calculada para cada um dos anos. Para facilitar a visualização no gráfico em termos de escala, a variância foi multiplicada por 1000 e, posteriormente, apresentada em forma logarítmica.

Os picos em 2000, 2003 e 2009 podem ser explicados, respectivamente, pelos efeitos da desvalorização da taxa de câmbio em 1999, 2002 e pela Crise Financeira de 2008. O elevado aumento na variância dos resíduos pode ser explicado pelas diferentes posições financeiras das empresas diante destes eventos, por exemplo, a empresa que possuía uma grande dívida em moeda estrangeira nos anos de desvalorização do câmbio pode ter contabilizado uma excessiva despesa financeira. Portanto, não se pode afirmar que a dispersão dos resíduos para os anos de 2000, 2002, 2003, 2008 e 2009 é determinada apenas pelos elementos discricionários em função dos efeitos das crises econômicas.

No primeiro período de adoção completa das IFRS, 2010, a variância dos resíduos é maior em relação aos anos de 2006 e 2007, sinalizando uma presença menor de componentes discricionários voltados para a suavização, coerente com a expectativa de redução de gerenciamento de resultados. Todavia, deve-se ressaltar que no primeiro ano de divulgação das demonstrações contábeis full IFRS, as empresas brasileiras passaram por diversas dificuldades de interpretação e aplicação das normas internacionais. Neste cenário de transição de GAAP, era esperado que a aplicação das novas normas provocasse alterações nos números contábeis, inclusive no lucro líquido. A divulgação dos primeiros balanços em IFRS 
poderia causar impacto negativo no mercado, desde que tais números contribuíssem para revelar um desempenho econômico inferior em relação ao balanço BRGAAP. Neste sentido, ações discricionárias visando uma menor variação do lucro podem ter sido aplicadas, sendo refletidas por uma menor dispersão dos resíduos em 2010 tomando-se como base de comparação os anos de 2004 e 2005. Portanto, o estudo do comportamento dos resíduos gerados pela equação 17 não permite relacionar claramente as ações discricionárias com a adoção completa das IFRS, sendo necessário observar os accruals discricionários dos modelos TEOH, JM e KS.

\subsubsection{Gerenciamento de Resultados segundo o Modelo TEOH}

A estatística descritiva para as variáveis do modelo TEOH podem ser observadas na tabela 11.

Tabela 11 - Estatística descritiva das variáveis do modelo TEOH, para o período 2000-2011

\begin{tabular}{|c|c|c|c|c|c|c|}
\hline \multirow[b]{2}{*}{$t$} & \multicolumn{2}{|c|}{$\frac{A T C_{j}}{\text { Asset }_{j}}$} & \multicolumn{2}{|c|}{$\frac{\Delta \operatorname{Rev}_{j}}{\text { Asset }_{j}}$} & \multicolumn{2}{|c|}{$\frac{1}{\text { Asset }_{j}}$} \\
\hline & $\mu$ & $\sigma$ & $\mu$ & $\sigma$ & $\mu$ & $\sigma$ \\
\hline 2000 & 0,0669 & 0,2977 & 0,2526 & 0,7368 & 0,0018 & 0,0069 \\
\hline 2001 & 0,0220 & 0,0826 & 0,1147 & 0,2014 & 0,0009 & 0,0016 \\
\hline 2002 & 0,0450 & 0,1010 & 0,1628 & 0,2709 & 0,0096 & 0,0669 \\
\hline 2003 & 0,0113 & 0,0557 & 0,1157 & 0,1787 & 0,0096 & 0,0686 \\
\hline 2004 & 0,0344 & 0,1289 & 0,3334 & 0,6722 & 0,0082 & 0,0577 \\
\hline 2005 & 0,0193 & 0,0685 & 0,1941 & 0,4901 & 0,0072 & 0,0520 \\
\hline 2006 & 0,0386 & 0,2831 & 0,2224 & 0,5571 & 0,0067 & 0,0482 \\
\hline 2007 & $-0,0053$ & 0,5919 & 0,3880 & 0,9138 & 0,0014 & 0,0060 \\
\hline 2008 & 0,0516 & 0,1641 & 0,2147 & 0,2973 & 0,0005 & 0,0007 \\
\hline 2009 & 0,0134 & 0,1272 & 0,1126 & 0,3161 & 0,0004 & 0,0005 \\
\hline 2010 & 0,0960 & 0,1820 & 0,1514 & 0,1946 & 0,0003 & 0,0005 \\
\hline 2011 & 0,0205 & 0,0837 & 0,0911 & 0,1582 & 0,0003 & 0,0004 \\
\hline
\end{tabular}

Nota: $A T C$ é o accrual total corrente das empresas segundo a equação $20 ; R e v_{j}$ é receita líquida da empresa $j$; Asset $_{j}$ é o ativo total.

Nota-se que a variável $\frac{A T C_{j}}{A s s e t_{j}}$ apresenta uma considerável oscilação ao longo do período 2000-2011, com destaque para 2010, ano da primeira adoção completa das IFRS, que apresenta a maior média. Isso significa que, a maior diferença entre o lucro líquido e fluxo de caixa operacional líquido, ambos deflacionados pelo ativo, ocorre no primeiro ano da adoção completa das IFRS. Era esperado que a adoção inicial provocasse mudanças substancias nos números reportados em função da aplicação de novas normas. 
Os coeficientes de correlação revelam uma fraca associação entre as variáveis do modelo, conforme pode ser observado na tabela 12 .

Tabela 12 - Correlação entre as variáveis do modelo TEOH

\begin{tabular}{c|c|c|c}
\hline & $\frac{A T C_{j}}{\text { Asset }_{j}}$ & $\frac{\Delta \operatorname{Rev}}{\text { Asset }_{j}}$ & $\frac{1}{\text { Asset }_{j}}$ \\
\hline$\frac{A T C_{j}}{\text { Asset }_{j}}$ & & $0,2241^{*}$ & $-0,1266^{*}$ \\
\hline$\frac{\Delta \operatorname{Rev} v_{j}}{\text { Asset }_{j}}$ & & & 0,0034 \\
\hline$\frac{1}{\text { Asset }_{j}}$ & & & \\
\hline
\end{tabular}

Nota: Coeficientes de correlação de Pearson. * coeficiente significante estatisticamente a 0,05.

A estimação dos coeficientes da equação 23 gerou os seguintes valores.

Tabela 13 - Estimativas geradas para o modelo TEOH

\begin{tabular}{lccc}
\hline & $\frac{A T C_{j, t}}{\text { Asset }_{j, t-1}}=\gamma_{1} \frac{1}{\text { Asset }_{j, t-1}}+\gamma_{2} \frac{\Delta \operatorname{Rev}_{j . t}}{\text { Asset }_{j, t-1}}+v_{j, t}$ & \\
\hline Variáveis & Coeficientes & $\mathbf{t}$ \\
\hline$\frac{\Delta \operatorname{Rev}_{j}}{\text { Asset }_{j}}$ & 0,100 & $5,91^{*}$ \\
\hline$\frac{1}{\text { Asset }_{j}}$ & $-719279,100$ & $-2,47^{* *}$ \\
\hline N. Obs. & & & \\
\hline $\mathrm{R}^{2}$ ajust. & 089 & \\
\hline Estatística F & $2,91 *$ & \\
\hline
\end{tabular}

Nota: Coeficientes *,** e e $^{* *}$ são significantes estatisticamente a nível de $0,01,0,05$ e 0,10 respectivamente.

Observa-se que os coeficientes são significantes estatisticamente, os quais são utilizados para calcular os accruals não discricionários das empresas por meio da equação 24. Após isso, os accruals discricionários, proxy para gerenciamento de resultado, são estimados pela equação 26.

É importante lembrar que esta abordagem é utilizada para avaliar a qualidade da informação contábil. Dechow (1994) explica que a administração tem alguma discricionariedade na elaboração das demonstrações contábeis. Esta discricionariedade pode ser usada para sinalizar informação oportuna ou manipular resultados, sendo que, na hipótese de manipulação, o lucro 
se torna uma medida menos confiável para avaliar o desempenho da empresa. O objetivo do modelo TEOH é mensurar, pelo menos de forma indireta, o exercício desta discricionariedade.

O comportamento dos accruals discricionários do modelo TEOH pode ser observado no gráfico a seguir.

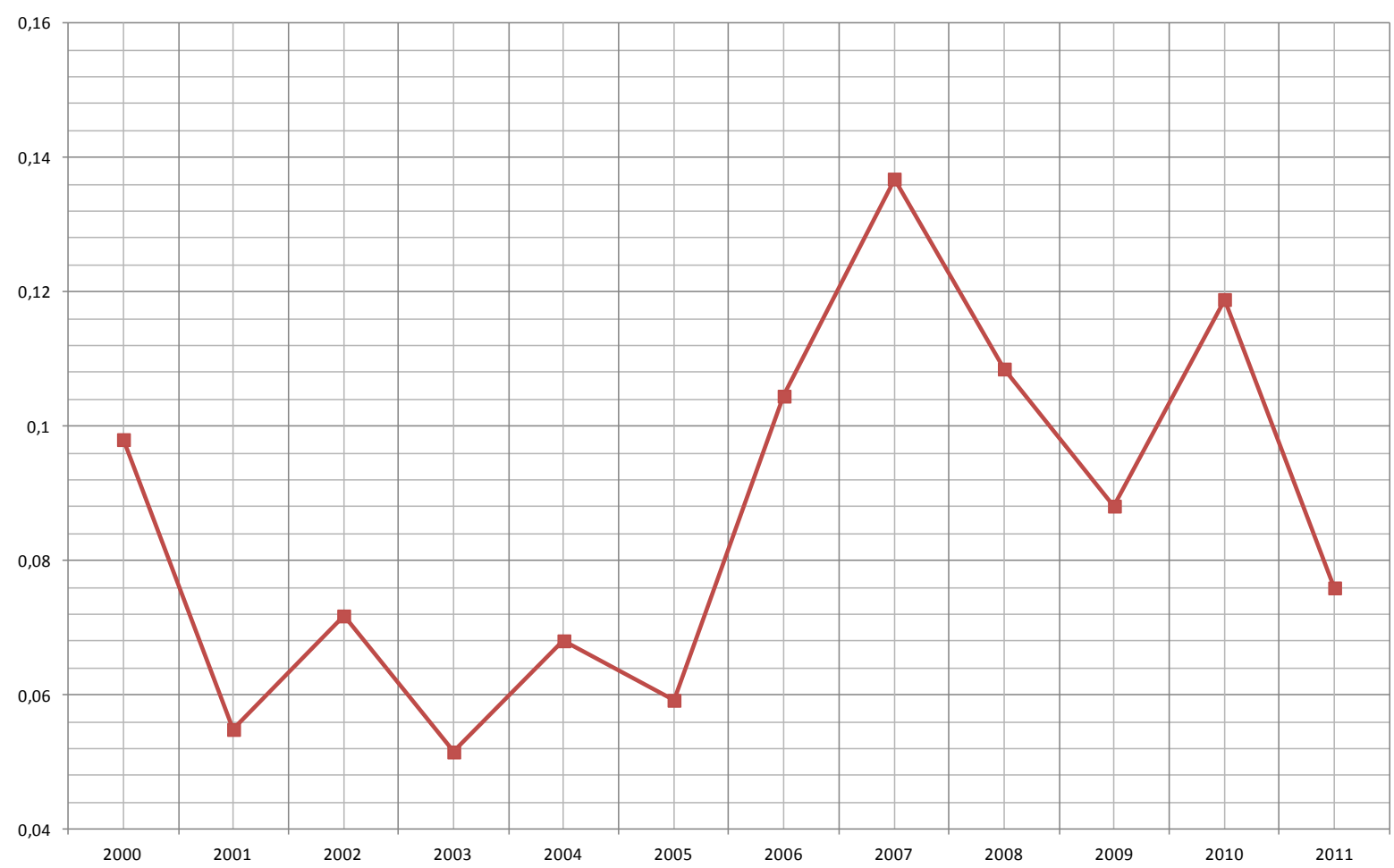

Gráfico 3 - Accruals discricionários estimados pelo modelo TEOH.

Nota: os accruals discricionários do modelo TEOH foram estimados com base na equação 26.

O gráfico revela que o nível de accruals discricionários (AD) é muito elevado em 2007 e 2010. O maior ponto do gráfico pode ser associado, mais uma vez, aos efeitos da Crise Financeira de 2008, influenciando a análise dos AD. No ano de 2010, o maior nível de AD, em comparação aos anos de 2009 e 2011, pode ser explicado por díspares interpretações das IFRS, em função de entendimento equivocado das alternativas de contabilização contidas na norma. Consequentemente, o modelo interpreta essa divergência dos números contábeis em IFRS como um exercício de discricionariedade, mas não necessariamente reflete a hipótese de manipulação prevista por Dechow (1994). Por outro lado, observa-se que o nível de AD caiu em 2011, o segundo ano da adoção completa das IFRS. Assumindo que os responsáveis pela elaboração das demonstrações contábeis tenham adquirido mais experiência no que diz respeito às IFRS, é possível que o tratamento heterogêneo para eventos similares tenha 
diminuído. A seção 4.5, baseada em Tendeloo e Vanstraelen (2005), traz evidências empíricas acerca do comportamento dos AD no período da adoção completa das IFRS.

\subsubsection{Gerenciamento de Resultados segundo o Modelo JM}

A estatística descritiva para as variáveis do modelo JM encontram-se na tabela 14, as outras variáveis do modelo JM encontram-se na tabela 11. A variável $\frac{A T_{j}}{A s s e t_{j}}$ refere-se ao accrual total, e também apresenta uma oscilação ao longo do período investigado, sendo que o ano de 2010 apresenta a maior média. Consequentemente, a maior diferença entre o lucro líquido e o fluxo de caixa operacional líquido ${ }^{45}$ também ocorre em 2010.

Ressalta-se que a diferença entre $\frac{A T C_{j}}{A s s e t_{j}}$ e $\frac{A T_{j}}{A s s e t_{j}}$ reside na consideração de contas de curto e longo prazo. O modelo TEOH parte dos accruals totais correntes, os quais são formados pelos componentes de curto prazo, pois considera que as contas de curto e longo prazo possuem comportamentos diferentes (PAULO, 2007).

Tabela 14 - Estatística descritiva das variáveis do modelo JM, para o período 2000-2011

\begin{tabular}{c|cc|cc}
\hline & \multicolumn{2}{|c|}{$A T_{j}$} & \multicolumn{2}{c}{$\frac{{ }^{2}}{\text { Asset }_{j}}$} \\
& $\mu$ & $\sigma$ & \multicolumn{2}{c}{ Asset $_{j}$} \\
\hline$t$ & $\mu$ & $\mu$ & $\sigma$ \\
\hline 2000 & 0,0114 & 0,2888 & 0,5277 & 0,5160 \\
\hline 2001 & $-0,0217$ & 0,0916 & 0,4438 & 0,2875 \\
\hline 2002 & $-0,0005$ & 0,0995 & 0,4527 & 0,2772 \\
\hline 2003 & $-0,0301$ & 0,0620 & 0,3982 & 0,2441 \\
\hline 2004 & 0,0344 & 0,1288 & 0,5916 & 1,5946 \\
\hline 2005 & $-0,0244$ & 0,0766 & 0,4001 & 0,2388 \\
\hline 2006 & $-0,0124$ & 0,3270 & 0,9047 & 4,1272 \\
\hline 2007 & $-0,0560$ & 0,5949 & 0,4852 & 0,6665 \\
\hline 2008 & 0,0044 & 0,1727 & 0,4031 & 0,2823 \\
\hline 2009 & $-0,0213$ & 0,1304 & 0,3810 & 0,3583 \\
\hline 2010 & 0,0635 & 0,1891 & 0,3444 & 0,3198 \\
\hline 2011 & $-0,0114$ & 0,0891 & 0,2902 & 0,2507 \\
\hline
\end{tabular}

Nota: a variável $A T_{j}$ corresponde aos accruals discricionários da empresa $j$ segundo a equação $18 ; P P E_{j}$ é o ativo imobilizado da empresa $j$; Asset $_{j}$ é o ativo total da empresa $j$.

\footnotetext{
${ }^{45} \mathrm{O}$ fluxo de caixa foi estimado pela diferença entre lucro e accrual total (equação 18).
} 
As variáveis $\frac{P P E_{j}}{A s s e t_{j}}$ e $\frac{A T_{j}}{A s s e t_{j}}$ (tabela 15) apresentam uma correlação negativa e moderada; enquanto as variáveis $\frac{P P E_{j}}{\text { Asset }_{j}}$ e $\frac{1}{\text { Asset }_{j}}$ também revelam uma associação moderada, porém positiva. Não revela surpresa que o coeficiente de correlação entre $\frac{P P E_{j}}{A s s e t_{j}}$ e $\frac{A T_{j}}{A s s e t_{j}}$ seja negativo, pois quanto maior a depreciação de bens do ativo imobilizado, menor será o ativo imobilizado da empresa e o lucro líquido, dado o registro de despesa de depreciação. Neste sentido, considerando que o accrual total é calculado pela diferença entre lucro líquido e fluxo de caixa, mantendo os outros fatores constantes, a redução do imobilizado (e também do ativo) por meio do registro da despesa de depreciação diminuirá o lucro e, consequentemente, afetará negativamente os accruals totais.

Tabela 15 - Correlação entre as variáveis do modelo JM

\begin{tabular}{l|c|c|c|c}
\hline & $\frac{A T_{j}}{\text { Asset }_{j,}}$ & $\frac{\Delta \operatorname{Rev}}{\text { Asset }_{j}}$ & $\frac{P P E_{j}}{\text { Asset }_{j}}$ & $\frac{1}{\text { Asset }_{j}}$ \\
\hline$\frac{A T_{j}}{\text { Asset }_{j}}$ & & $0,1968^{*}$ & $-0,3464^{*}$ & $-0,1345^{*}$ \\
\hline$\frac{\Delta \operatorname{Re} v_{j}}{\text { Asset }_{j}}$ & & & $0,0854^{*}$ & 0,0034 \\
\hline$\frac{P P E_{j}}{\text { Asset }_{j}}$ & & & & $0,3438^{*}$ \\
\hline$\frac{1}{\text { Asset }_{j}}$ & & & & \\
\hline
\end{tabular}

Nota: Coeficientes de correlação de Pearson. * coeficiente significante estatisticamente a 0,05.

Os coeficientes estimados para o modelo JM podem ser vistos na tabela 16. 
Tabela 16 - Estimativas geradas para o modelo JM

\begin{tabular}{|c|c|c|}
\hline$\frac{A T_{j, t}}{\text { Asset }_{j, t-1}}=\kappa$ & $\frac{1}{\text { Asset }_{j, t-1}}+\kappa_{2} \frac{\Delta \operatorname{Re} v_{j . t}}{\text { Asset }_{j, t-1}}+$ & $\kappa_{3} \frac{P P E_{j . t}}{\text { Asset }_{j, t-1}}+\varepsilon_{j, t}$ \\
\hline Variáveis & Coeficientes & $\mathbf{t}$ \\
\hline$\frac{\Delta \operatorname{Rev}{ }_{j}}{\text { Asset }_{j}}$ & 0,110 & $2,79^{*}$ \\
\hline$\frac{P P E_{j}}{\text { Asset }_{j}}$ & $-0,061$ & $-4,34 *$ \\
\hline$\frac{1}{\text { Asset }_{j}}$ & 23111,150 & 0,06 \\
\hline N. Obs. & & 889 \\
\hline $\mathrm{R}^{2}$ ajust. & & 0,27 \\
\hline Estatística F & & $4,52 *$ \\
\hline
\end{tabular}

Nota: Coeficientes *,** e *** são significantes estatisticamente a nível de $0,01,0,05$ e 0,10 respectivamente.

Observa-se que os apenas os coeficientes estimados para as variáveis $\frac{\Delta \operatorname{Rev} v_{j}}{A s s e t_{j}}$ e $\frac{P P E_{j}}{A s s e t_{j}}$ são significantes estatisticamente. O sinal da variável $\frac{1}{\text { Asset }_{j}}$ é positivo ao contrário do sinal apresentado na tabela 12, sendo que as principais diferenças entre os modelos TEOH e JM devem-se a presença da variável $\frac{P P E_{j}}{A s s e t_{j}}$ e a variável dependente $-\frac{A T C_{j}}{A s s e t_{j}}$ para TEOH e $\frac{A T_{j}}{A s s e t_{j}}$ para JM. Uma explicação para a inversão do sinal de $\frac{1}{A s s e t_{j}}$ pode ser dada a partir da correlação positiva e moderada entre as variáveis $\frac{1}{\text { ssset }_{j}}$ e $\frac{P P E_{j}}{\text { Asset }_{j}}$, pois, segundo Gujarati (2006), a presença de colinearidade pode se constatada a partir do exame dos coeficientes de correlação entre duas variáveis explicativas.

Os coeficientes da tabela 16 são utilizados para calcular os accruals não discricionários das empresas por meio da equação 22. Após isso, os accruals discricionários, proxy para gerenciamento de resultado, são estimados pela equação 25 .

O gráfico 4 apresenta a média dos accruals discricionários no período 2000-2011. 


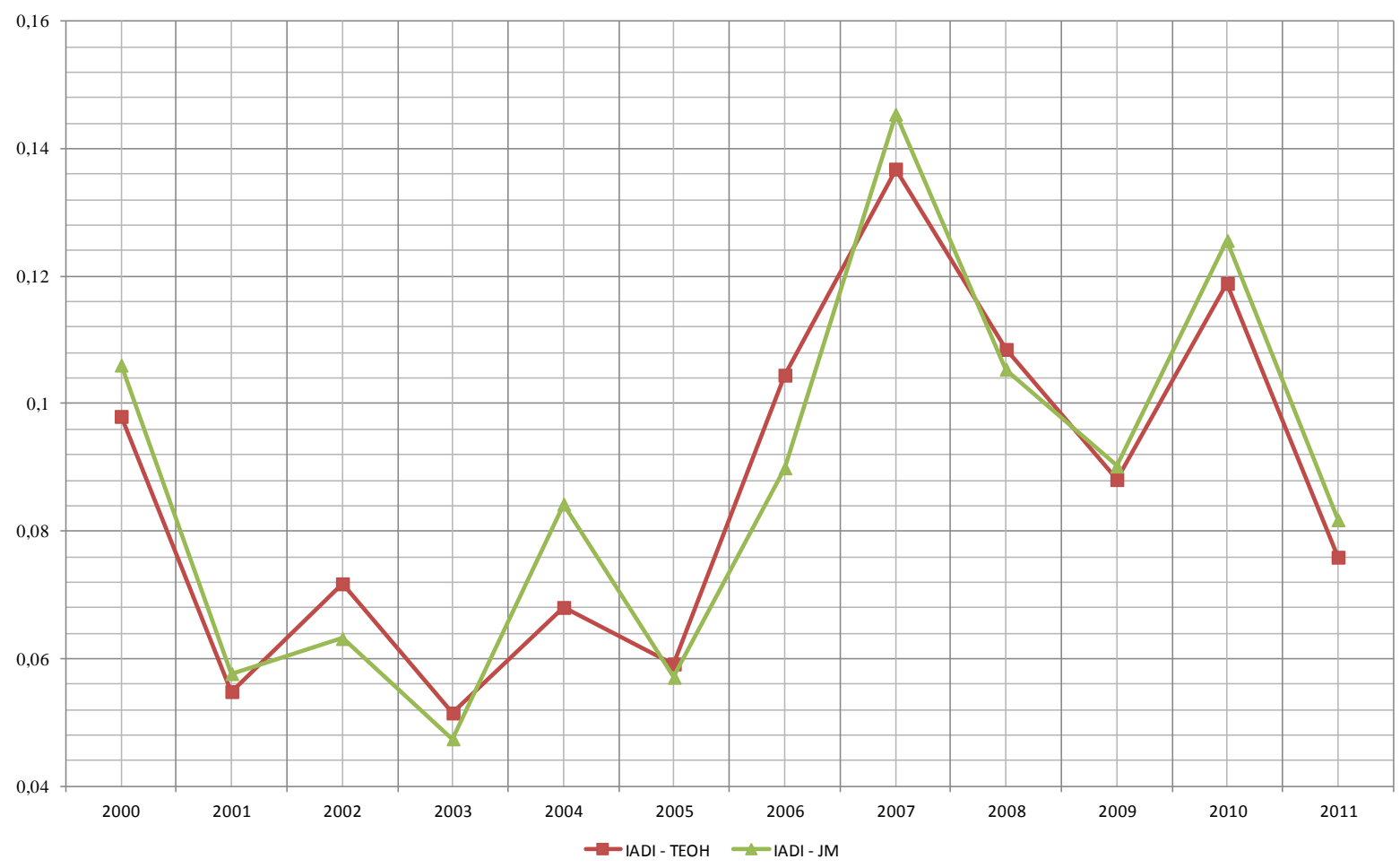

Gráfico 4 - accruals discricionários estimados pelo modelo JM e TEOH.

Nota: os accruals discricionários dos modelos TEOH e JM foram estimados com base nas equações 26 e 25 , respectivamente. Os mesmos são apresentados em módulo.

Nota-se que os accruals discricionários estimados pelos modelos TEOH e JM são muito próximos, o que pode ser explicado pelas semelhanças entre os modelos comentadas anteriormente.

\subsubsection{Gerenciamento de Resultados segundo o Modelo KS}

O modelo KS dado pela equação 30 apresenta resultados satisfatórios em relação a outros modelos de gerenciamento de resultados encontrados na literatura (MARTINEZ, 2001). É importante destacar que, as variáveis independentes do modelo KS são formadas a partir de variáveis instrumentais baseadas em contas das demonstrações contábeis - estas variáveis são comentadas na apresentação do modelo KS (seção 3.3.1). As estatísticas descritivas de tais variáveis encontram-se a seguir. 
Tabela 17 - Estatística descritiva das variáveis do modelo KS, para o período 2000-2011

\begin{tabular}{|c|c|c|c|c|c|c|c|c|}
\hline \multirow[b]{2}{*}{$t$} & \multicolumn{2}{|c|}{$\left[\frac{A T_{j}}{A \operatorname{sset}_{j,}}\right]$} & \multicolumn{2}{|c|}{$\left[\frac{C R_{j, t-1}}{\operatorname{Re} v_{j, t-1}} \times \operatorname{Re} v_{j, t}\right]$} & \multicolumn{2}{|c|}{$\left[\frac{A P B_{j, t-1}}{E X P_{j, t-1}} \times E X P_{j, t}\right]$} & \multicolumn{2}{|c|}{$\frac{D E P}{j, t-1}_{P P E_{j, t-1}} \times P P E_{j, t}$} \\
\hline & $\mu$ & $\sigma$ & $\mu$ & $\sigma$ & $\mu$ & $\sigma$ & $\mu$ & $\sigma$ \\
\hline 2000 & 0,01141 & 0,28883 & 0,11726 & 0,08914 & 0,02104 & 0,16102 & 0,03827 & 0,04090 \\
\hline 2001 & $-0,02166$ & 0,09164 & 0,11936 & 0,09568 & $-0,02398$ & 0,10369 & 0,03786 & 0,02867 \\
\hline 2002 & $-0,00050$ & 0,09950 & 0,11920 & 0,09517 & 0,00769 & 0,20405 & 0,03665 & 0,03180 \\
\hline 2003 & $-0,03009$ & 0,06202 & 0,12502 & 0,08056 & $-0,03109$ & 0,32637 & 0,03841 & 0,03044 \\
\hline 2004 & 0,03436 & 0,12880 & 0,13532 & 0,09483 & $-0,00266$ & 0,11704 & 0,04083 & 0,03976 \\
\hline 2005 & $-0,02443$ & 0,07665 & 0,14108 & 0,10224 & $-0,01869$ & 0,12244 & 0,00004 & 0,00003 \\
\hline 2006 & $-0,01243$ & 0,32697 & 0,13661 & 0,15369 & $-0,01892$ & 0,18280 & 0,03547 & 0,03177 \\
\hline 2007 & $-0,05603$ & 0,59494 & 0,12873 & 0,08589 & $-0,01220$ & 0,14370 & 0,03210 & 0,03295 \\
\hline 2008 & 0,00436 & 0,17269 & 0,13164 & 0,10393 & $-0,03476$ & 0,18051 & 0,03441 & 0,03343 \\
\hline 2009 & $-0,02131$ & 0,13043 & 0,11223 & 0,09283 & $-0,00951$ & 0,13770 & 0,03544 & 0,03156 \\
\hline 2010 & 0,06348 & 0,18910 & 0,12340 & 0,11036 & $-0,03614$ & 0,12663 & 0,02783 & 0,02933 \\
\hline 2011 & $-0,01144$ & 0,08906 & 0,13960 & 0,13053 & 0,00371 & 0,16162 & 0,02656 & 0,02096 \\
\hline
\end{tabular}

Nota: $A T$ são os accruals totais estimados a partir de equação 18; $C R$ é o contas a receber da empresa $j$; Rev é a receita de vendas da empresa $j$; $A P B$ é o capital de giro líquido sem considerar contas a receber da empresa $j$; $E X P$ é a despesa operacional antes da depreciação e amortização da empresa $j$; $D E P$ é a despesa de depreciação e amortização; Asset é o ativo total da empresa $j$; e $P P E$ é o ativo imobilizado da empresa $j$.

A análise de correlação revela uma correlação fraca entre as variáveis do modelo KS.

Tabela 18 - Correlação entre as variáveis do modelo KS

\begin{tabular}{|c|c|c|c|c|}
\hline & {$\left[\frac{A T_{j}}{\text { Asset }_{j}}\right]$} & {$\left[\frac{C R_{j, t-1}}{\operatorname{Re} v_{j, t-1}} \times \operatorname{Re} v_{j, t}\right]$} & {$\left[\frac{A P B_{j, t-1}}{E X P_{j, t-1}} \times E X P_{j, t}\right]$} & $\frac{D E P_{j, t-1}}{P P E_{j, t-1}} \times P P E_{j, t}$ \\
\hline$\left[\frac{A T_{j}}{A s s e t_{j,}}\right]$ & & $0,2112 *$ & $0,0814 *$ & $-0,1373^{*}$ \\
\hline$\left[\frac{C R_{j, t-1}}{\operatorname{Re} v_{j, t-1}} \times \operatorname{Rev} v_{j, t}\right]$ & & & $-0,1315^{*}$ & $-0,1291^{*}$ \\
\hline$\left[\frac{A P B_{j, t-1}}{E X P_{j, t-1}} \times E X P_{j, t}\right]$ & & & & $-0,1320^{*}$ \\
\hline$\left[\frac{D E P_{j, t-1}}{P P E_{j, t-1}} \times P P E_{j, t}\right]$ & & & & \\
\hline
\end{tabular}

Nota: Coeficientes de correlação de Pearson. * coeficiente significante estatisticamente a 0,05.

Por sua vez, as estimativas para o modelo KS podem ser encontradas na tabela 19. 
Tabela 19 - Estimativas geradas para o modelo KS

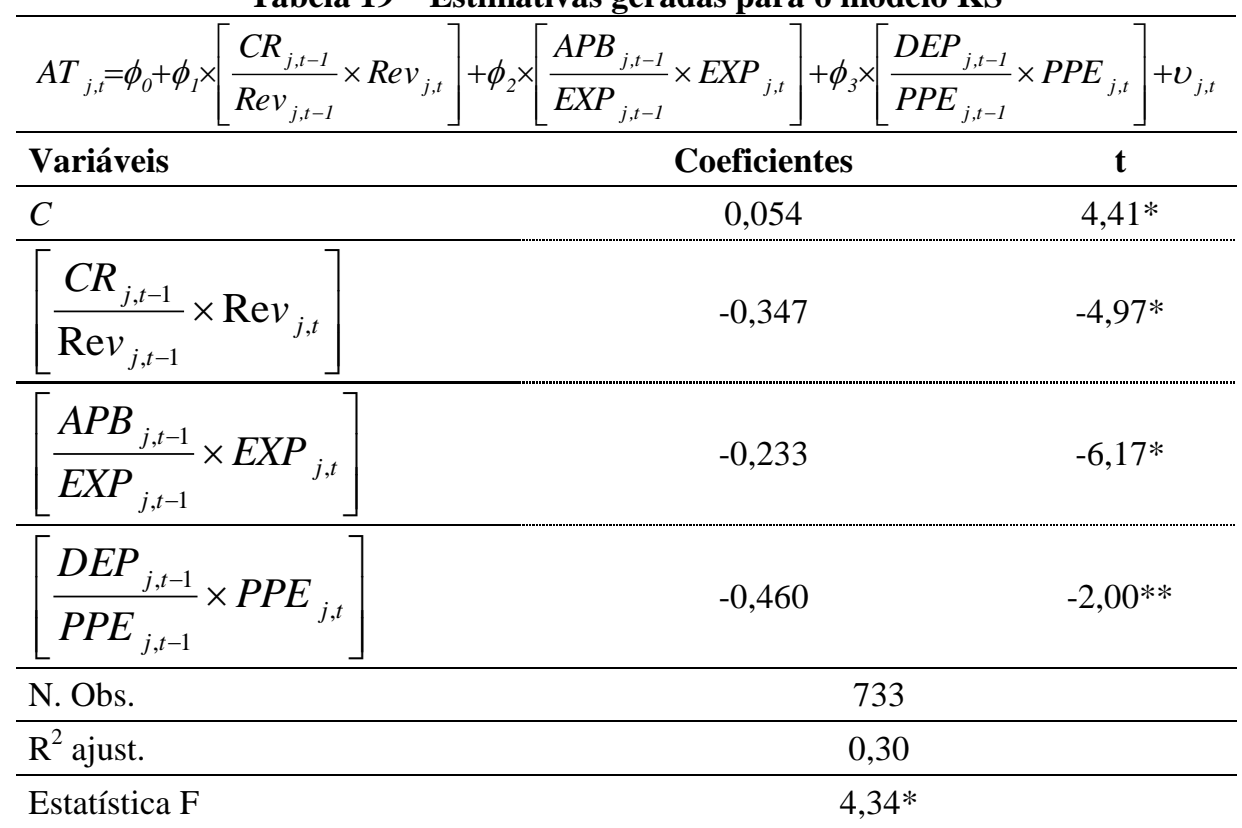

Nota: Coeficientes *,** e *** são significantes estatisticamente a nível de $0,01,0,05$ e 0,10 respectivamente.

Todos os coeficientes são estatisticamente significantes, sendo que o coeficiente de determinação é de 0,30 .

No entanto, torna-se interessante analisar os resíduos gerados pelo modelo KS. O gráfico a seguir permite comparar o comportamento dos accruals discricionários no período 20002011, para os três modelos: TEOH, JM e KS. 


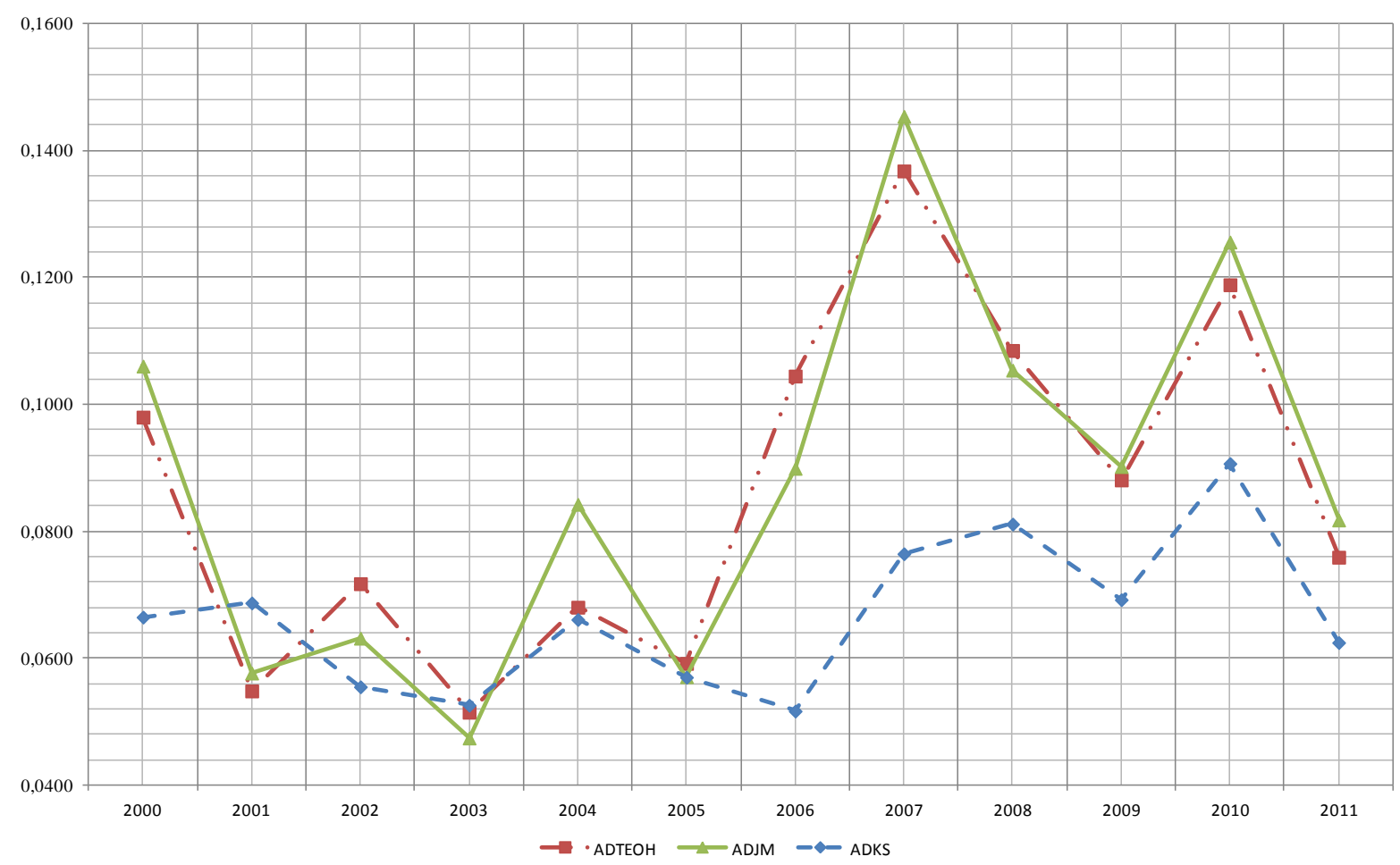

Gráfico 5 - Accruals discricionários estimados pelos modelos JM, TEOH e KS.

Nota: os accruals discricionários dos modelos TEOH e JM foram estimados com base na equação 26 e 25 , respectivamente; os accruals discricionários do modelo KS são representados pelos resíduos da equação 30.

Conforme comentou-se anteriormente o comportamento dos AD para os modelos TEOH e JM é similar. No que diz respeito ao modelo KS, nota-se que os AD apresentam variações nos mesmos períodos, por exemplo, em 2004, 2007 e 2010 há um aumento no nível de AD para os três modelos; por outro lado, em 2003, 2005, 2009 e 2011 há uma redução no nível de AD para os três modelos. Essas variações demonstram que o comportamento dos AD pelos três modelos é convergente.

\subsubsection{Gerenciamento de Resultados: a relação entre accruals discricionários e a adoção completa das IFRS}

Uma vez que a análise dos modelos de gerenciamento de resultados tenha sido realizada, é fundamental investigar se o nível de AD estimados reduziu-se estatisticamente no período da adoção completa: 2010 e 2011. Para isso, o modelo adaptado de Tendeloo e Vanstraelen (2005) foi aplicado.

A matriz de correlação para as variáveis utilizadas do modelo encontra-se na tabela 20. Dada a alta correlação entre $S I Z E$ e $C F$ optou-se pela apresentação de apenas uma variável no 
modelo, para evitar problemas de multicolinearidade. Neste caso, a variável SIZE foi excluída do modelo.

Tabela 20 - correlação entre as variáveis $A D_{K S}, A D_{T E O H}, A D_{J M}, C F$, SIZE e DEBT

\begin{tabular}{l|c|c|c|c|c|c}
\hline & $A D_{K S}$ & $A D_{T E O H}$ & $A D_{J M}$ & $C F$ & $S I Z E$ & $D E B T$ \\
\hline$A D_{K S}$ & & $0,7210^{*}$ & $0,7381^{*}$ & $-0,0732$ & $-0,1374^{*}$ & $-0,0327$ \\
\hline$A D_{T E O H}$ & & & $0,9482^{*}$ & $-0,1386^{*}$ & $-0,1867^{*}$ & $-0,0168$ \\
\hline$A D_{J M}$ & & & & $-0,1317^{*}$ & $-0,1525^{*}$ & $-0,0158$ \\
\hline$C F$ & & & & & $0,7783^{*}$ & $-0,030$ \\
\hline$S I Z E$ & & & & & & $-0,059$ \\
\hline$D E B T$ & & & & & & \\
\hline
\end{tabular}

Nota: Coeficientes de correlação de Pearson. * coeficiente significante estatisticamente a 0,$05 ; A D_{K S}$ é uma proxy de gerenciamento de resultados (GR) calculada a partir da equação $30 ; A D_{T E O H}$ e $A D_{J M}$ são proxies de GR dadas pelas equações 26 e 25 , respectivamente; $C F$ é o fluxo de caixa operacional estimado pela diferença entre lucro líquido e accruals total (SLOAN, 1996); SIZE é o logaritmo natural do ativo total; e DEBT é o total de dívidas dividido pelo total do patrimônio líquido.

A correlação entre as variáveis de gerenciamento de resultados $-A D_{K S}, A D_{T E O H}$ e $A D_{J M}-$ é alta, corroborando a análise gráfica anterior, isto é, as proxies de gerenciamento possuem uma forte associação. Ademais, as três proxies de GR possuem uma relação negativa com tamanho (SIZE), indicando que quanto maior a empresa, menor será o gerenciamento de resultados.

As estimativas geradas para o modelo podem ser observadas na tabela 21 .

Tabela 21 - Estimativas geradas para a equação 31, baseada em Tendeloo e Vanstraelen (2005)

\begin{tabular}{|c|c|c|}
\hline \multicolumn{3}{|c|}{$\left|A D_{K S i t}\right|=\beta_{0}+\beta_{1} I F R S_{i t}+\beta_{2} A D R_{i t}+\beta_{3} B C G I_{i t}+\beta_{4} C F_{i t}+\beta_{5} D E B T_{i t}+\varepsilon_{i t}$} \\
\hline Variáveis & Coeficientes & $\mathbf{t}$ \\
\hline$C$ & $-0,005$ & $-0,13$ \\
\hline IFRS & $-0,007$ & $-1,70 * * *$ \\
\hline$B C G I$ & $-0,001$ & $-0,05$ \\
\hline$A D R$ & $-0,032$ & $-3,45^{*}$ \\
\hline$C F$ & 0,004 & $1,93^{*}$ \\
\hline$D E B T$ & $-0,001$ & $-1,37$ \\
\hline N. Obs. & \multicolumn{2}{|c|}{545} \\
\hline $\mathrm{R}^{2}$ ajust. & \multicolumn{2}{|c|}{0,01} \\
\hline Estatística F & \multicolumn{2}{|c|}{$2,97 * *$} \\
\hline
\end{tabular}

Nota: $\left|A D_{K S}\right|$ refere-se a proxy de gerenciamento de resultado baseada no modelo KS (equação 30). Coeficientes $*, * * \mathrm{e}^{* * *}$ são significantes estatisticamente a nível de $0,01,0,05$ e 0,10 respectivamente.

Ressalta-se que o modelo estimado na tabela 21 tem como variável dependente a proxy $A D_{K S}$, que corresponde aos resíduos da equação 30. Optou-se por usar o modelo KS considerando o resultado satisfatório na literatura (MARTINEZ, 2001). 
Neste caso, a variável de interesse é IFRS, que revela o efeito da adoção completa no comportamento dos accruals discricionários. De acordo com a tabela 21, a variável IFRS é significante estatisticamente a 0,10 e apresenta sinal negativo, revelando que os $\mathrm{AD}$, proxy para as práticas de gerenciamento de resultado, diminuíram no período da adoção completa. Este resultado é consistente com a hipótese de pesquisa que prevê uma redução no gerenciamento de resultados no período da adoção completa das IFRS. No entanto, quando as variáveis $A D_{T E O H}$ e $A D_{J M}$ assumem o papel de variável dependente na equação 31 , a variável IFRS não é significante estatisticamente, apesar de manter o sinal negativo.

Estes resultados são contrários aos achados de Tendeloo e Vanstraelen (2005), que observaram um aumento na magnitude dos accruals discricionários em empresas alemãs na adoção das IFRS. Eles concluíram que a adoção de um elevado padrão de normas contábeis não é condição suficiente para fornecer informação de alta qualidade em países code law, onde se observa baixa proteção aos direitos dos investidores.

Em testes não reportados, a interação entre as variáveis IFRS e ADR revela uma estimativa de -0,014, significante estatisticamente a 0,01. O mesmo teste para a interação entre IFRS, ADR e BCGI apresenta uma maior redução no nível de accruals discricionários durante a adoção completa, visto que a estimativa é de -0,026, significante estatisticamente a 0,01.

\subsection{Análise do Conservadorismo Condicional}

Esta subseção é dividida em três partes: i) o reconhecimento oportuno de perdas segundo Basu (1997) - equação 32; ii) componentes transitórios de ganhos e perdas segundo Basu (1997) - equação 35; iii) análise do conservadorismo com base no modelo de Ball e Shivakumar (2005) - equação 36.

\subsubsection{O reconhecimento oportuno de perdas segundo Basu (1997)}

As estatísticas descritivas para as principais variáveis utilizadas no modelo de Basu (1997) encontram-se a seguir. 
Tabela 22 - Estatística descritiva das variáveis $R E T, D R, D R * R E T$ e ADR para o período 2000-2011

\begin{tabular}{c|cc|cc|cc|cc}
\hline & \multicolumn{2}{|c|}{$R E T$} & \multicolumn{2}{c|}{$D R$} & \multicolumn{2}{c}{$D R * R E T$} & \multicolumn{2}{c}{$A D R$} \\
\hline$t$ & $\mu$ & $\sigma$ & $\mu$ & $\sigma$ & $\mu$ & $\sigma$ & $\mu$ & $\sigma$ \\
\hline 2000 & 0,1422 & 0,5475 & 0,5250 & 0,5057 & $-0,1828$ & 0,2903 & 0,1290 & 0,3371 \\
\hline 2001 & 0,1961 & 0,5510 & 0,4286 & 0,5009 & $-0,1817$ & 0,3089 & 0,1505 & 0,3595 \\
\hline 2002 & 0,1200 & 0,6424 & 0,4524 & 0,5038 & $-0,1919$ & 0,3127 & 0,1720 & 0,3795 \\
\hline 2003 & 0,9519 & 0,8622 & 0,0698 & 0,2578 & $-0,0281$ & 0,1540 & 0,1720 & 0,3795 \\
\hline 2004 & 0,6388 & 1,4050 & 0,3182 & 0,4712 & $-0,0930$ & 0,2252 & 0,1935 & 0,3972 \\
\hline 2005 & 0,6460 & 0,7743 & 0,2115 & 0,4124 & $-0,0838$ & 0,2253 & 0,1935 & 0,3972 \\
\hline 2006 & 0,5027 & 0,5228 & 0,0893 & 0,2877 & $-0,0107$ & 0,0374 & 0,2151 & 0,4131 \\
\hline 2007 & 0,2206 & 0,6360 & 0,2794 & 0,4520 & $-0,0732$ & 0,1601 & 0,2366 & 0,4273 \\
\hline 2008 & $-0,2595$ & 0,2895 & 0,7381 & 0,4423 & $-0,3180$ & 0,2716 & 0,2473 & 0,4338 \\
\hline 2009 & 0,7178 & 0,7365 & 0,0341 & 0,1825 & $-0,0053$ & 0,0292 & 0,2473 & 0,4338 \\
\hline 2010 & 0,1678 & 0,3816 & 0,3889 & 0,4902 & $-0,0868$ & 0,1601 & 0,2581 & 0,4399 \\
\hline 2011 & $-0,0106$ & 0,4364 & 0,5054 & 0,5027 & $-0,2134$ & 0,2957 & 0,2688 & 0,4457 \\
\hline
\end{tabular}

Nota: Ret é o retorno do preço da ação para a empresa $i$ no ano $t$; e $D R$ é uma dummy que assume 1 quando o retorno da ação é negativo e 0 caso contrário; $R_{e}{ }^{*} D R$ é uma interação entre as variáveis Ret e $D R ; A D R$ é uma dummy que recebe 1 para as empresas que emitem ADRs na NYSE

As maiores médias para a variável Ret foram em 2003 e 2009, refletindo a recuperação da BM\&F BOVESPA após duas crises: a desvalorização da taxa de câmbio em 2002 e a Crise Financeira de 2008 (COSTA; REIS; TEIXEIRA, 2012).

Em seguida, pode-se analisar os coeficientes de correlação (tabela 23). A matriz de correlação revela que a variável $E A R N$ possui uma correlação positiva e fraca com RET. Acredita-se que outras variáveis influenciam o comportamento de lucro e retorno, explicando esta baixa associação.

Tabela 23 - Correlação entre as variáveis $E A R N$, RET e DR*RET.

\begin{tabular}{c|c|c|c}
\hline & $E A R N$ & $R E T$ & $D R * R E T$ \\
\hline$E A R N$ & & $0,1779 *$ & $0,1690^{*}$ \\
\hline$R E T$ & & & $0,5874 *$ \\
\hline$D R * R E T$ & & & \\
\hline
\end{tabular}

Nota: Coeficientes de correlação de Pearson. * coeficiente significante estatisticamente a 0,05; EARN é o resultado por ação da empresa $i$ para o ano $t$.

O próximo passo corresponde à análise das estimativas para o modelo original e suas variações (tabela 24). As variações do modelo abrangem a adição das variáveis: IFRS, ADR e BCGI. 
Tabela 24 - Estimativas geradas para o modelo de reconhecimento oportuno de perdas segundo Basu (1997), e suas variações

\begin{tabular}{|c|c|c|c|c|c|}
\hline & Original & IFRS & $\begin{array}{c}\text { IFRS e } \\
\text { ADR }\end{array}$ & $\begin{array}{c}\text { IFRS e } \\
\text { BCGI }\end{array}$ & $\begin{array}{c}\text { IFRS, ADR } \\
\text { e BCGI }\end{array}$ \\
\hline Variáveis & $\begin{array}{c}\text { Coeficientes } \\
\text { / t }\end{array}$ & $\begin{array}{c}\text { Coeficientes } \\
/ \mathrm{t}\end{array}$ & $\begin{array}{c}\text { Coeficientes } \\
/ \mathrm{t}\end{array}$ & $\begin{array}{c}\text { Coeficientes } \\
/ \mathrm{t}\end{array}$ & $\begin{array}{c}\text { Coeficientes } \\
/ \mathbf{t}\end{array}$ \\
\hline$C$ & $\begin{array}{r}1,859 / \\
(8,22)^{*} \\
\end{array}$ & $\begin{array}{r}1,826 / \\
(6,23)^{*} \\
\end{array}$ & $\begin{array}{c}0,764 / \\
(1,89)^{* *} \\
\end{array}$ & $\begin{array}{c}0,631 / \\
(1,56) \\
\end{array}$ & $\begin{array}{c}0,608 / \\
(1,33)\end{array}$ \\
\hline$D R$ & $\begin{array}{c}-0,671 /(- \\
2,72)^{*}\end{array}$ & $\begin{array}{c}-0,964 /(- \\
3,60)^{*}\end{array}$ & $\begin{array}{c}-0,886 /(- \\
2,75)^{*}\end{array}$ & $\begin{array}{c}-0,891 /(- \\
2,70)^{*}\end{array}$ & $\begin{array}{c}-0,882 /(- \\
2,63)^{*}\end{array}$ \\
\hline$R E T$ & $\begin{array}{c}0,234 / \\
(0,47) \\
\end{array}$ & $\begin{array}{c}0,241 / \\
(0,47) \\
\end{array}$ & $\begin{array}{c}0,202 / \\
(0,42) \\
\end{array}$ & $\begin{array}{c}0,203 / \\
(0,40) \\
\end{array}$ & $\begin{array}{c}0,227 / \\
(0,47) \\
0\end{array}$ \\
\hline$D R * R E T$ & $\begin{array}{c}1,123 / \\
(2,29)^{* *}\end{array}$ & $\begin{array}{c}0,457 / \\
(1,33) \\
\end{array}$ & $\begin{array}{c}0,284 / \\
(0,57) \\
\end{array}$ & $\begin{array}{c}0,239 / \\
(0,47)\end{array}$ & $\begin{array}{c}-0,042 /(- \\
0,07)\end{array}$ \\
\hline$I F R S$ & & $\begin{array}{c}0,123 / \\
(0,41) \\
\end{array}$ & $\begin{array}{c}-0,066 /(- \\
0,27) \\
\end{array}$ & $\begin{array}{c}1,926 / \\
(2,12)^{* *} \\
\end{array}$ & $\begin{array}{c}0,061 / \\
(0,26)\end{array}$ \\
\hline$I F R S * D R$ & & $\begin{array}{c}0,884 / \\
(2,34)^{* *}\end{array}$ & $\begin{array}{c}0,478 / \\
(1,01)\end{array}$ & $\begin{array}{c}2,081 / \\
(1,92) * * *\end{array}$ & $\begin{array}{c}0,562 / \\
(0,95)\end{array}$ \\
\hline$I F R S * R E T$ & & $\begin{array}{c}0,050 / \\
(0,27) \\
\end{array}$ & $\begin{array}{c}0,258 / \\
(2,13)^{* *} \\
\end{array}$ & $\begin{array}{c}0,338 / \\
(2,14) * * \\
\end{array}$ & $\begin{array}{c}0,035 / \\
(0,09)\end{array}$ \\
\hline$I F R S^{*} D R * R E T$ & & $\begin{array}{l}2,145 / \\
(3,00)^{*} \\
\end{array}$ & $\begin{array}{c}1,635 / \\
(2,01)^{* *}\end{array}$ & $\begin{array}{c}1,806 / \\
(2,01)^{* *}\end{array}$ & $\begin{array}{c}2,067 / \\
(2,22)^{* *}\end{array}$ \\
\hline$I F R S^{*} A D R$ & & & $\begin{array}{l}1,646 / \\
(5,10)^{*} \\
\end{array}$ & & \\
\hline$I F R S^{*} D R * A D R$ & & & $\begin{array}{c}-0,842 /(- \\
4,93)^{*}\end{array}$ & & \\
\hline$I F R S^{*} R E T * A D R$ & & & $\begin{array}{c}-1,864 /(- \\
6,21)^{*}\end{array}$ & & \\
\hline$I F R S * D R * R E T * A D R$ & & & $\begin{array}{l}1,898 / \\
(2,71)^{*}\end{array}$ & & \\
\hline$B C G I * I F R S$ & & & & $\begin{array}{c}-2,742 /(- \\
2,20)^{* *} \\
\end{array}$ & \\
\hline$I F R S^{*} D R * B C G I$ & & & & $\begin{array}{c}-2,419 /(- \\
1,40)\end{array}$ & \\
\hline$I F R S^{*} R E T * B C G I$ & & & & $\begin{array}{c}0,051 / \\
(0,07) \\
\end{array}$ & \\
\hline$I F R S^{*} D R^{*} R E T * B C G I$ & & & & $\begin{array}{c}\mathbf{0 , 0 5 8} / \\
(0,06) \\
\end{array}$ & \\
\hline$B C G I * I F R S * A D R$ & & & & & $\begin{array}{l}2,446 / \\
(3,91)^{*}\end{array}$ \\
\hline$I F R S * D R * B C G I * A D R$ & & & & & $\begin{array}{c}-2,221 /(- \\
7,45)^{*}\end{array}$ \\
\hline$I F R S^{*} R E T^{*} B C G I^{*} A D R$ & & & & & $\begin{array}{c}-3,284 /(- \\
3,23)^{*}\end{array}$ \\
\hline$I F R S^{*} D R * R E T * B C G I * A D R$ & & & & & $\begin{array}{c}3,128 / \\
(1,78)^{* * *}\end{array}$ \\
\hline Indústria & Não & Sim & $\mathrm{Sim}$ & $\mathrm{Sim}$ & Sim \\
\hline N. Obs. & 742 & 742 & 742 & 742 & 742 \\
\hline $\mathrm{R}^{2}$ ajust. & 0,03 & 0,03 & 0,09 & 0,09 & 0,05 \\
\hline Estatística F & $9,40 *$ & $4,35^{*}$ & $3,61 *$ & $3,57 *$ & $2,32 *$ \\
\hline
\end{tabular}

Coeficientes $*, * *$ e $* * *$ são significantes estatisticamente a nível de $0,01,0,05$ e 0,10 respectivamente. 
Tomando-se o retorno da ação como proxy para o resultado econômico da empresa, a maior associação entre os retornos negativos e a variável EARN (lucro por ação) sugere que as empresas, de maneira geral, reconhecem as perdas econômicas de maneira mais oportuna. Esse reconhecimento oportuno de perdas também pode ser denominado de conservadorismo condicional.

De acordo com o modelo original o resultado possui característica de conservadorismo, pois a soma dos coeficientes $\beta_{2}$ e $\beta_{3}(0,234+1,123)$ é superior a $\beta_{2}(0,234)$. Embora o coeficiente $\beta_{2}$ não seja significante estatisticamente, o coeficiente $\beta_{3}$, conhecido como coeficiente de Basu, mede a oportunidade incremental do reconhecimento de perdas no resultado em relação aos ganhos, e mostra-se significante estatisticamente a 0,05 .

Ao adicionar a variável IFRS no modelo original, a variável IFRS*DR*RET revela a existência de tempestividade incremental do reconhecimento de perdas, ao apresentar um coeficiente positivo e significante estatisticamente a 0,01. Além disso, o coeficiente de 2,145 apresenta-se maior em relação à variável $D R^{*} R E T$, revelando que o efeito do conservadorismo é maior no período da adoção completa: 2010 e 2011. Este resultado permite confirmar a hipótese de pesquisa sobre conservadorismo, que prevê um aumento no nível de conservadorismo das demonstrações contábeis após adoção completa das IFRS.

A consideração das variáveis IFRS e $A D R$ no modelo original permite analisar o conservadorismo após adoção completa, em especial para as empresas que possuem ADRs. Essas companhias devem se adequar aos rigorosos padrões e níveis de disclosure exigidos pela Securities and Exchange Comission (SEC), e ainda estão sujeitas à SOX. Consequentemente, há incentivos para práticas superiores de governança corporativa, o que pode influenciar o nível de conservadorismo incorporado nas demonstrações contábeis. A variável de interesse $I F R S^{*} D R^{*} R E T * A D R$ confirma tal expectativa ao apresentar um coeficiente positivo e significante estatisticamente a nível de 0,01 . Acrescenta-se a isso a magnitude deste coeficiente $(1,898)$, que é maior em relação ao coeficiente estimado para o período de adoção completa sem considerar $A D R(1,635)$.

A análise da interação entre as variáveis IFRS e BCGI não revelou um reconhecimento oportuno e incremental de perdas no resultado, pois a variável de interesse $I F R S^{*} D R * R E T * B C G I$ não se mostrou significante estatisticamente. No entanto, ao interagir 
as variáveis IFRS, BCGI e $A D R$, a variável de interesse dada por IFRS*DR*RET*BCGI*ADR apresenta um coeficiente de maior magnitude e positivo $(3,128)$, embora significante estatisticamente a nível de 0,10. Este resultado fornece indícios de que, as empresas emitentes de ADRs apresentam maior nível de conservadorismo no período de adoção completa (2010 e 2011), ao considerar as práticas de governança corporativa pelo BCGI. Este resultado é coerente com Lopes e Walker (2008), que constatou um aumento no conservadorismo condicional ao considerar mecanismos de governança corporativa.

Os achados desta tese são contrários às evidências empíricas de Coelho (2007), que investigou o conservadorismo condicional no período 1995-2004. Essa evolução na qualidade da informação contábil, também observada por Almeida (2010), pode ser explicada por vários fatores, com destaque para os aspectos institucionais, como a garantia dos direitos de investidores não majoritários respaldados pela CVM; e o próprio processo de convergência às IFRS, um conjunto de normas de elevada qualidade segundo trabalhos empíricos e autoridades do IASB.

No contexto da adoção completa, Braga (2011) também investigou o reconhecimento assimétrico de ganhos e perdas no Brasil. De forma geral, o autor concluiu que, a adoção das IFRS não afetou o reconhecimento oportuno de perdas, reduzindo a qualidade da informação contábil. No entanto, ressalta-se que o período de adoção analisado restringe-se ao ano de 2010, o que caracteriza estas evidências empíricas, segundo o autor, como preliminares.

\subsubsection{Componentes transitórios de ganhos e perdas segundo Basu (1997)}

O modelo de componentes transitórios é desenvolvido a partir da variação do lucro entre $t$ e $t$ 1. Assim, apresentam-se as estatísticas descritivas para esta variável na tabela 25. 
Tabela 25 - Estatística descritiva da variável $\triangle E A R N$ para o período 2000-2011

\begin{tabular}{c|c|c}
\hline & \multicolumn{2}{|c}{$\triangle E A R N$} \\
\hline$t$ & $\mu$ & $\sigma$ \\
\hline 2000 & $-0,0052$ & 0,2180 \\
\hline 2001 & 0,0097 & 0,0772 \\
\hline 2002 & $-0,0195$ & 0,0846 \\
\hline 2003 & 0,0484 & 0,0858 \\
\hline 2004 & 0,0565 & 0,1657 \\
\hline 2005 & 0,0255 & 0,0619 \\
\hline 2006 & 0,0174 & 0,0657 \\
\hline 2007 & $-3,9143$ & 3,5945 \\
\hline 2008 & $-0,0051$ & 0,0882 \\
\hline 2009 & 0,0362 & 0,1126 \\
\hline 2010 & 0,0219 & 0,0537 \\
\hline 2011 & $-0,0091$ & 0,0537 \\
\hline
\end{tabular}

Fonte: $\triangle E A R N$ refere-se à diferença entre o lucro em $t$ e $t$ - 1 .

A média da variável $\triangle E A R N$ apresenta-se positiva ao longo do período de estudo, exceto pelos anos 2000, 2002, 2007, 2008 e 2010. A desvalorização da taxa de câmbio em 2002 pode explicar a variação negativa do lucro, enquanto a Crise Financeira de 2008 pode explicar as variações negativas de 2007 e 2008.

As estimativas para o modelo original de componentes transitórios de ganhos e perdas e suas variações podem ser observadas na tabela 26. 
Tabela 26 - Estimativas geradas para o modelo de componentes transitórios de ganhos e perdas segundo Basu (1997), e suas variações

\begin{tabular}{|c|c|c|c|c|c|}
\hline & Original & IFRS & $\begin{array}{c}\text { IFRS e } \\
\text { ADR }\end{array}$ & $\begin{array}{c}\text { IFRS e } \\
\text { BCGI }\end{array}$ & $\begin{array}{c}\text { IFRS, ADR } \\
\text { e BCGI }\end{array}$ \\
\hline Variáveis & $\begin{array}{c}\text { Coeficientes } \\
/ \mathrm{t}\end{array}$ & $\begin{array}{c}\text { Coeficientes } \\
/ \mathrm{t}\end{array}$ & $\begin{array}{c}\text { Coeficientes } \\
/ \mathrm{t}\end{array}$ & $\begin{array}{c}\text { Coeficientes } \\
/ \mathrm{t}\end{array}$ & $\begin{array}{c}\text { Coeficientes } \\
/ \mathrm{t}\end{array}$ \\
\hline$C$ & $\begin{array}{l}0,012 / \\
(3,13)^{*}\end{array}$ & $\begin{array}{c}0,016 / \\
(1,46) \\
\end{array}$ & $\begin{array}{c}0,016 / \\
(1,46)\end{array}$ & $\begin{array}{c}0,016 / \\
(1,43) \\
\end{array}$ & $\begin{array}{c}0,016 / \\
(1,42) \\
\end{array}$ \\
\hline$\triangle E A R N_{t-1}$ & $\begin{array}{c}-0,089 /(- \\
1,20) \\
\end{array}$ & $\begin{array}{c}-0,123 /(- \\
1,23) \\
\end{array}$ & $\begin{array}{c}-0,124 /(- \\
1,24)\end{array}$ & $\begin{array}{c}-0,126 /(- \\
1,25)\end{array}$ & $\begin{array}{c}-0,125 /(- \\
1,25) \\
\end{array}$ \\
\hline$D \triangle E A R N_{t-1}$ & $\begin{array}{c}0,012 / \\
(1,01) \\
\end{array}$ & $\begin{array}{c}0,023 / \\
(1,59) \\
\end{array}$ & $\begin{array}{c}0,022 / \\
(1,56) \\
\end{array}$ & $\begin{array}{c}0,022 / \\
(1,53) \\
\end{array}$ & $\begin{array}{c}0,022 / \\
(1,56) \\
\end{array}$ \\
\hline$D \triangle E A R N_{t-1} * \Delta E A R N_{t-1}$ & $\begin{array}{c}\mathbf{0 , 0 3 7 ~ I ~} \\
(\mathbf{0 , 4 2})\end{array}$ & $\begin{array}{c}0,075 / \\
(0,69)\end{array}$ & $\begin{array}{c}0,076 / \\
(0,70)\end{array}$ & $\begin{array}{c}0,078 / \\
(0,71)\end{array}$ & $\begin{array}{c}0,076 / \\
(0,70)\end{array}$ \\
\hline$\triangle E A R N_{t-1} * I F R S$ & & $\begin{array}{l}0,048 / \\
(0,40)\end{array}$ & $\begin{array}{c}0,084 / \\
(0,67)\end{array}$ & $\begin{array}{c}-0,473 /(- \\
1,35)\end{array}$ & $\begin{array}{c}0,083 / \\
(0,67)\end{array}$ \\
\hline$D \triangle E A R N_{t-1} * I F R S$ & & $\begin{array}{c}-0,054 /(- \\
2,31)^{* *}\end{array}$ & $\begin{array}{c}-0,062 /(- \\
2,58)^{*}\end{array}$ & $\begin{array}{c}-0,003 /(- \\
0,05) \\
\end{array}$ & $\begin{array}{c}-0,060 /(- \\
2,46)^{*}\end{array}$ \\
\hline$D \triangle E A R N_{t-1} * \triangle E A R N_{t-1} * I F R S$ & & $\begin{array}{c}-0,482 /(- \\
3,74)^{*}\end{array}$ & $\begin{array}{c}-0,562 /(- \\
2,61)^{*}\end{array}$ & $\begin{array}{c}-0,348 /(- \\
0,36)\end{array}$ & $\begin{array}{c}-0,610 /(- \\
2,77)^{*}\end{array}$ \\
\hline$\triangle E A R N_{t-1} * A D R * I F R S$ & & & $\begin{array}{c}-0,188 /(- \\
2,70)^{*}\end{array}$ & & \\
\hline$D \triangle E A R N_{t-1} * A D R * I F R S$ & & & $\begin{array}{c}0,028 / \\
(1,88)^{* * *}\end{array}$ & & \\
\hline$D \triangle E A R N_{t-1} * \triangle E A R N_{t-1} * A D R * I F R S$ & & & $\begin{array}{c}\mathbf{0 , 3 8 6} / \\
(\mathbf{0 , 5 5}) \\
\end{array}$ & & \\
\hline$\triangle E A R N_{t-1} * B C G I * I F R S$ & & & & $\begin{array}{c}0,736 / \\
(1,39) \\
\end{array}$ & \\
\hline$D \triangle E A R N_{t-1} * B C G I * I F R S$ & & & & $\begin{array}{c}-0,075 /(- \\
1,35) \\
\end{array}$ & \\
\hline$D \triangle E A R N_{t-1} * \triangle E A R N_{t-1} * B C G I * I F R S$ & & & & $\begin{array}{c}\mathbf{0 , 2 0 1 /} \\
(\mathbf{0 , 1 4}) \\
\end{array}$ & \\
\hline$\triangle E A R N_{t-1} * I F R S^{*} B C G I^{*} A D R$ & & & & & $\begin{array}{c}-0,313 /(- \\
3,55)^{*}\end{array}$ \\
\hline$D \triangle E A R N_{t-1} * I F R S^{*} B C G I^{*} A D R$ & & & & & $\begin{array}{c}0,046 / \\
(1,84)^{* * *}\end{array}$ \\
\hline $\begin{array}{l}D \triangle E A R N_{t-1} * \triangle E A R N_{t-} \\
I^{* I F R S}{ }^{*} B C G I^{*} A D R\end{array}$ & & & & & $\begin{array}{c}1,137 / \\
(\mathbf{0 , 8 5}) \\
\end{array}$ \\
\hline Indústria & Não & $\mathrm{Sim}$ & Sim & Sim & Sim \\
\hline N. Obs. & 797 & 797 & 797 & 797 & 797 \\
\hline $\mathrm{R}^{2}$ ajust. & 0,04 & 0,05 & 0,05 & 0,05 & 0,05 \\
\hline Estatística F & $1,15^{*}$ & $2,94 *$ & $2,68 *$ & $2,75^{*}$ & $2,67 *$ \\
\hline
\end{tabular}

Nota: Coeficientes $*$, ** e *** são significantes estatisticamente a nível de 0,01, 0,05 e 0,10 respectivamente. $\triangle E A R N$ refere-se à diferença entre o lucro em t e t-1; $\triangle E A R N_{t-1}$ é a variação do lucro em $t-1 ; D \Delta E A R N_{t-1}$ é uma dummy que assume 1 quando a variação do lucro em $t-1$ é negativa e 0 caso contrário; $D \Delta E A R N_{t-1} * E A R N_{t-1}$ é fruto da interação entre $\triangle E A R N_{t-1}$ e $D \Delta E A R N_{t-1}$.

A ideia geral do modelo baseia-se nos conceitos de persistência, tempestividade e reversão. $\mathrm{O}$ reconhecimento oportuno de perdas pode ser entendido como a antecipação de eventos que determinam variações negativas no lucro, conduzindo a tempestividade e baixa persistência. 
Neste sentido, os lucros futuros não sofrerão variações em função das más notícias correntes, gerando uma reversão da redução do lucro corrente no próximo exercício social. Se, em média, as empresas estão reconhecendo as más notícias antecipadamente (em $t$-l) e revertendo o efeito no exercício social seguinte (em $t$ ) o coeficiente $\beta_{3}$ deve ser negativo, revelando o reconhecimento oportuno de perdas.

As estimativas para o modelo original (tabela 27) não revelam reconhecimento oportuno de perdas para a amostra, pois a variável $D \triangle E A R N_{t-1} * \Delta E A R N_{t-1}$ não é significante estatisticamente, além de apresentar sinal positivo. No entanto, ao considerar a dummy de IFRS, a variável de interesse dada por DAEARN $N_{t-1} * \Delta E A R N_{t-1} *$ IFRS é significante estatisticamente a 0,01 e apresenta sinal negativo, conforme previsto pelo modelo. Este resultado revela um reconhecimento oportuno de perdas no período de adoção completa das IFRS, conforme prevê a hipótese de pesquisa sobre conservadorismo. A análise conjunta das variáveis IFRS, ADR e BCGI não revelou reconhecimento oportuno de perdas, visto que as

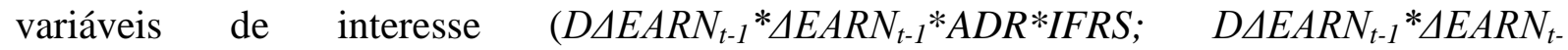

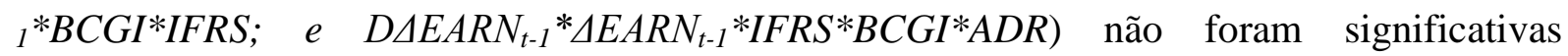
estatisticamente, além de apresentarem sinal positivo.

\subsubsection{O reconhecimento oportuno de perdas segundo Ball e Shivakumar (2005)}

As estatísticas descritivas para as principais variáveis do modelo podem ser vistas na tabela 27. 
Tabela 27 - Estatística descritiva das variáveis $A T$ e $F C O$, para o período 2000-2011

\begin{tabular}{c|c|c|c|c}
\hline & \multicolumn{2}{|c|}{$A T$} & \multicolumn{2}{c}{$F C O$} \\
\hline$t$ & $\mu$ & $\sigma$ & $\mu$ & $\sigma$ \\
\hline 2000 & 0,0114 & 0,2888 & $-0,0124$ & 0,4828 \\
\hline 2001 & $-0,0217$ & 0,0916 & 0,0487 & 0,0979 \\
\hline 2002 & $-0,0005$ & 0,0995 & 0,0023 & 0,1414 \\
\hline 2003 & $-0,0301$ & 0,0620 & 0,0745 & 0,0987 \\
\hline 2004 & 0,0344 & 0,1288 & 0,0613 & 0,1224 \\
\hline 2005 & $-0,0244$ & 0,0766 & 0,1094 & 0,1209 \\
\hline 2006 & $-0,0124$ & 0,3270 & 0,0971 & 0,3274 \\
\hline 2007 & $-0,0560$ & 0,5949 & 0,0736 & 0,2723 \\
\hline 2008 & 0,0044 & 0,1727 & 0,0500 & 0,1817 \\
\hline 2009 & $-0,0213$ & 0,1304 & 0,0996 & 0,1501 \\
\hline 2010 & 0,0635 & 0,1891 & 0,0234 & 0,2008 \\
\hline 2011 & $-0,0114$ & 0,0891 & 0,0725 & 0,1380 \\
\hline
\end{tabular}

Nota: $A T$ é dado pela equação 18 e dividido pelo ativo em $t-1 ; F C O$ é o fluxo de caixa operacional dado pela diferença entre lucro líquido e accruals, dividido pelo ativo em $t-1$.

As variáveis $A T$ e $F C O$ apresentam grande oscilação ao longo do período 2000-2011. As estimativas para o modelo original de Ball e Shivakumar (2005) e suas variações podem ser observadas na tabela 29 . 
Tabela 28 - Estimativas geradas para o modelo de reconhecimento oportuno de perdas segundo Ball e Shivakumar (2005), e suas variações

\begin{tabular}{|c|c|c|c|c|c|}
\hline & Original & IFRS & $\begin{array}{c}\text { IFRS e } \\
\text { ADR }\end{array}$ & $\begin{array}{c}\text { IFRS e } \\
\text { BCGI }\end{array}$ & $\begin{array}{c}\text { IFRS, ADR } \\
\text { e BCGI }\end{array}$ \\
\hline Variáveis & $\begin{array}{c}\text { Coeficientes } \\
\text { / t }\end{array}$ & $\begin{array}{c}\text { Coeficientes } \\
\text { / t }\end{array}$ & $\begin{array}{c}\text { Coeficientes } \\
\qquad / \mathbf{t}\end{array}$ & $\begin{array}{c}\text { Coeficientes } \\
/ / \mathbf{t}\end{array}$ & $\begin{array}{c}\text { Coeficientes } \\
/ \mathbf{t}\end{array}$ \\
\hline$C$ & $\begin{array}{l}0,055 / \\
(5,03)^{*}\end{array}$ & $\begin{array}{c}0,151 / \\
(2,10)^{* *}\end{array}$ & $\begin{array}{c}0,152 / \\
(2,11)^{* *}\end{array}$ & $\begin{array}{c}0,153 / \\
(2,13)^{* *}\end{array}$ & $\begin{array}{c}0,152 / \\
(2,10)^{* *}\end{array}$ \\
\hline$F C O$ & $\begin{array}{c}-0,794 /(- \\
1,26)^{*}\end{array}$ & $\begin{array}{c}-0,749 /(- \\
7,20)^{*}\end{array}$ & $\begin{array}{c}-0,750 /(- \\
7,22)^{*}\end{array}$ & $\begin{array}{c}-0,749 /(- \\
7,22)^{*}\end{array}$ & $\begin{array}{c}-0,750 /(- \\
7,23)^{*}\end{array}$ \\
\hline$D F C O$ & $\begin{array}{c}-0,021 /(- \\
1,09)\end{array}$ & $\begin{array}{c}-0,034 /(- \\
1,16)\end{array}$ & $\begin{array}{c}-0,034 /(- \\
1,17)\end{array}$ & $\begin{array}{c}-0,034 /(- \\
1,17)\end{array}$ & $\begin{array}{c}-0,034 /(- \\
1,17)\end{array}$ \\
\hline$F C O * D F C O$ & $\begin{array}{c}0,178 / \\
(2,24)^{* *}\end{array}$ & $\begin{array}{c}0,169 / \\
(1,96)^{* *}\end{array}$ & $\begin{array}{c}0,170 / \\
(1,97)^{* *}\end{array}$ & $\begin{array}{c}0,169 / \\
(1,96)^{* *}\end{array}$ & $\begin{array}{c}0,170 / \\
(1,97)^{* *}\end{array}$ \\
\hline$F C O * I F R S$ & & $\begin{array}{l}0,169 / \\
(2,85)^{*}\end{array}$ & $\begin{array}{l}0,189 / \\
(2,56)^{*}\end{array}$ & $\begin{array}{c}-0,096 /(- \\
0,41)\end{array}$ & $\begin{array}{l}0,193 / \\
(2,65)^{*}\end{array}$ \\
\hline$D F C O * I F R S$ & & $\begin{array}{c}0,005 / \\
(0,18)\end{array}$ & $\begin{array}{c}0,011 / \\
(0,37)\end{array}$ & $\begin{array}{c}0,052 / \\
(1,28)\end{array}$ & $\begin{array}{c}0,013 / \\
(0,43)\end{array}$ \\
\hline$F C O * D F C O * I F R S$ & & $\begin{array}{c}-\mathbf{0 , 6 0 5} /(- \\
9,59)^{*}\end{array}$ & $\begin{array}{c}-0,633 /(- \\
8,79)^{*}\end{array}$ & $\begin{array}{c}-0,573 /(- \\
2,26)^{* *}\end{array}$ & $\begin{array}{c}-0,633 /(- \\
8,98)^{*}\end{array}$ \\
\hline$F C O * I F R S^{*} A D R$ & & & $\begin{array}{c}-0,078 /(- \\
1,03)\end{array}$ & & \\
\hline$D F C O * I F R S * A D R$ & & & $\begin{array}{c}0,004 / \\
(0,28)\end{array}$ & & \\
\hline$F C O * D F C O * I F R S * A D R$ & & & $\begin{array}{c}0,682 / \\
(2,49) * *\end{array}$ & & \\
\hline$F C O * I F R S^{*} B C G I$ & & & & $\begin{array}{c}0,431 / \\
(1,06)\end{array}$ & \\
\hline$D F C O * I F R S^{*} B C G I$ & & & & $\begin{array}{c}-0,075 /(- \\
0,89)\end{array}$ & \\
\hline$F C O * D F C O * I F R S * B C G I$ & & & & $\begin{array}{c}-0,119 /(- \\
0,31)\end{array}$ & \\
\hline$F C O * I F R S * B C G I * A D R$ & & & & & $\begin{array}{c}-0,186 /(- \\
1,29)\end{array}$ \\
\hline$D F C O * I F R S^{*} B C G I^{*} A D R$ & & & & & $\begin{array}{c}-0,014 /(- \\
0,58)\end{array}$ \\
\hline$F C O * D F C O * I F R S^{*} B C G I^{*} A D R$ & & & & & $\begin{array}{l}0,909 / \\
(2,57)^{*}\end{array}$ \\
\hline Indústria & Não & Sim & Sim & Sim & Sim \\
\hline N. Obs. & 889 & 889 & 889 & 889 & 889 \\
\hline $\mathrm{R}^{2}$ ajust. & 0,42 & 0,32 & 0,32 & 0,32 & 0,32 \\
\hline Estatística F & $7,88^{*}$ & $1,94 *$ & $1,71 *$ & $1,72 *$ & $1,72 *$ \\
\hline
\end{tabular}

Nota: Coeficientes *, ** e *** são significantes estatisticamente a nível de 0,01, 0,05 e 0,10 respectivamente. 
O modelo explora o reconhecimento assimétrico entre ganhos e perdas econômicas por meio de accruals. Ball e Shivakumar (2005) defendem uma relação positiva entre fluxo de caixa corrente e accruals, sendo maior quando há reconhecimento oportuno de perdas econômicas ainda não realizadas. Segundo Ball e Shivakumar (2005), as perdas são mais prováveis em períodos de fluxo de caixa negativo, portanto, espera-se um coeficiente positivo para a variável $F C O * D F C O$.

O modelo original revela que a variável de interesse dada por $F C O * D F C O$ é significante estatisticamente e apresenta o sinal esperado. Por outro lado, ao acrescentar a dummy de IFRS, não se observa reconhecimento oportuno de perdas, pois a variável $F C O * D F C O * I F R S$ apresenta sinal contrário ao previsto. Este resultado revela que os números contábeis deixaram de atender o aspecto de reconhecimento oportuno de perdas.

Contudo, este resultado é alterado ao analisar as variáveis $F C O^{*} D F C O^{*} I F R S^{*} A D R$ e $F C O * D F C O * I F R S^{*} B C G I^{*} A D R$, pois ambas são significantes estatisticamente a 0,05 e 0,01 respectivamente, além de apresentarem sinal positivo, conforme previsto pelo modelo. Neste sentido, pode-se afirmar que houve aumento no conservadorismo condicional após adoção completa das IFRS, pelo menos para as empresas que possuem ADRs na NYSE. Além disso, ao considerar o BCGI, a magnitude do coeficiente gerado para a variável $F C O * D F C O * I F R S^{*} B C G I^{*} A D R$ é maior, mostrando que o reconhecimento oportuno de perdas após adoção completa das IFRS é maior para as empresas que emitem ADRs na NYSE, controlando pelas diferenças em termos de governança corporativa (BCGI). Logo, estas evidências são favoráveis à aceitação da hipótese de aumento do conservadorismo condicional.

\subsection{Análise da Relevância da Informação Contábil}

As estatísticas descritivas para as principais variáveis do modelo de relevância encontram-se na tabela 29. 
Tabela 29 - Estatística descritiva das variáveis do modelo de relevância, para o período 2000-2011

\begin{tabular}{c|cc|cc|cc}
\hline & \multicolumn{2}{|c|}{$P_{i t}$} & \multicolumn{2}{c|}{$B V_{i t}$} & \multicolumn{2}{c}{$E A R N_{i t}$} \\
\hline$t$ & $\mu$ & $\sigma$ & $\mu$ & $\sigma$ & $\mu$ & $\sigma$ \\
\hline 2000 & 1,2174 & 0,5269 & 0,1768 & 0,6420 & 2,2817 & 4,9238 \\
\hline 2001 & 1,1257 & 0,5217 & 0,2689 & 0,8207 & 1,8125 & 4,1666 \\
\hline 2002 & 1,0706 & 0,4912 & 0,1491 & 0,8998 & 1,6623 & 3,3965 \\
\hline 2003 & 1,8443 & 0,6881 & 0,6728 & 1,5377 & 2,5903 & 5,2495 \\
\hline 2004 & 1,6423 & 1,5166 & 0,4780 & 0,9770 & 1,6790 & 2,8591 \\
\hline 2005 & 1,6288 & 0,6528 & 0,3714 & 0,5692 & 1,2769 & 1,6015 \\
\hline 2006 & 1,4157 & 0,4422 & 0,1917 & 0,2910 & 0,9571 & 1,2551 \\
\hline 2007 & 1,1605 & 0,4396 & 0,2355 & 0,8013 & 1,1382 & 2,0075 \\
\hline 2008 & 0,7257 & 0,2902 & 0,1253 & 0,3341 & 1,1256 & 2,9638 \\
\hline 2009 & 1,6593 & 0,6454 & 0,1551 & 0,1940 & 1,2146 & 1,2962 \\
\hline 2010 & 1,1588 & 0,3641 & 0,1032 & 0,1100 & 0,7538 & 0,5604 \\
\hline 2011 & 0,9825 & 0,4462 & 0,0455 & 0,1121 & 0,6368 & 0,4715 \\
\hline
\end{tabular}

Nota: onde $P_{i t}$ é o preço da ação três meses após o encerramento do ano fiscal em $t$, deflacionado pelo preço em $t$-1 para a empresa $i ; B V_{i t}$ é o patrimônio líquido por ação da empresa $i$ para o período $t$, deflacionado pelo preço em $t-1 ; E A R N_{i t}$ é o resultado líquido por ação da empresa $i$ para o período $t$, deflacionado pelo preço em $t-1$.

A maior média aritmética de $P$ ocorre em 2003, enquanto a menor é observada em 2008, refletindo as consequências da Crise Financeira de 2008. Além disso, observa-se que a variável EARN apresenta uma tendência de crescimento até 2003, revertendo para uma tendência de queda até 2011. No que tange à variável $B V$, nota-se que a maior média ocorre em 2003, sendo que, em 2011 encontra-se a menor média do período 2010-2011.

No entanto, os valores da tabela 29 foram ajustados pela quantidade de ações e pelo preço em t-1. Para visualizar o comportamento das variáveis lucro e patrimônio líquido sem os ajustes de escala, as mesmas foram plotadas nos gráficos a seguir. 


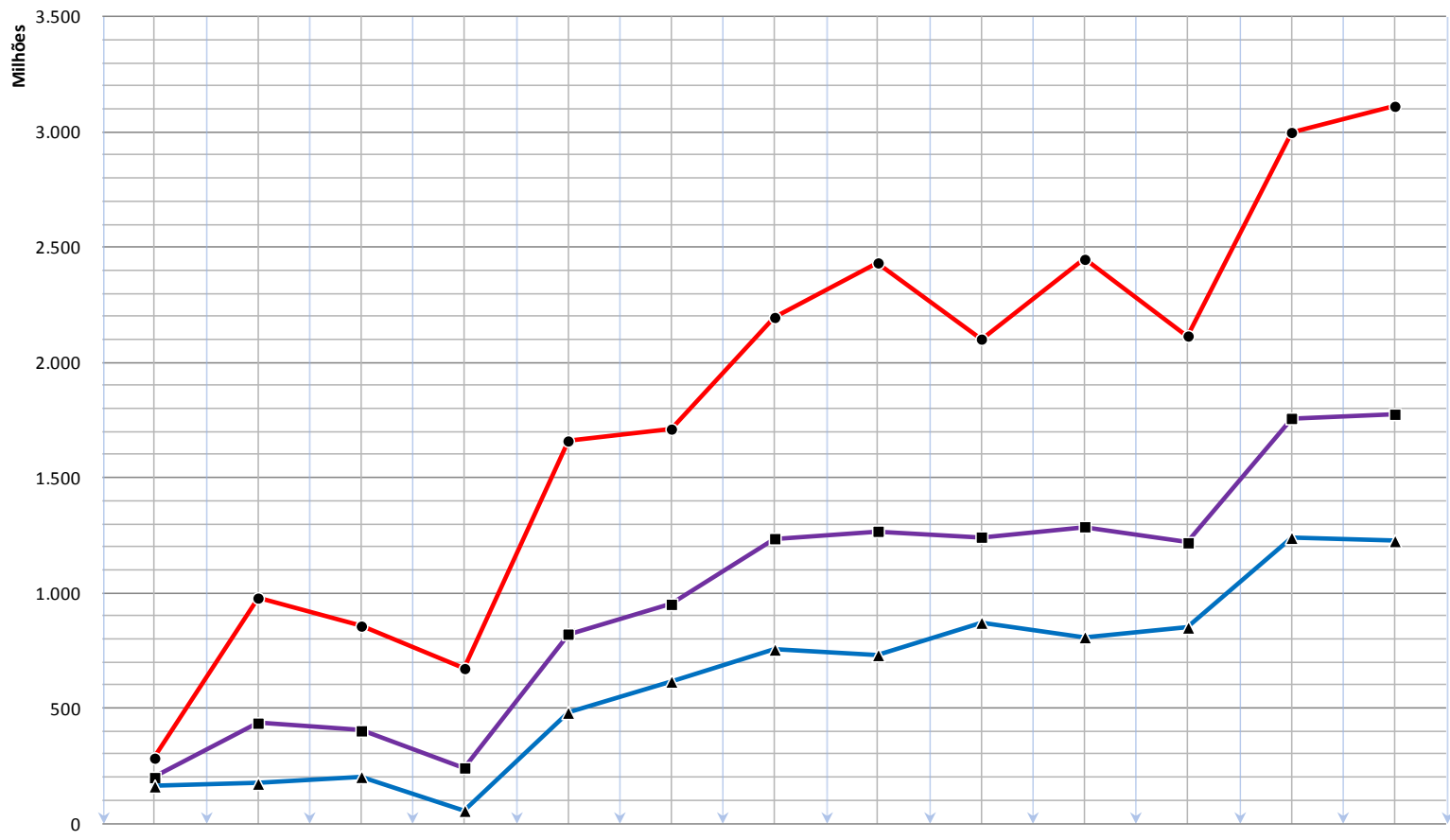

Lucro 1999 Lucro 2000 Lucro 2001 Lucro 2002 Lucro 2003 Lucro 2004 Lucro 2005 Lucro 2006 Lucro 2007 Lucro 2008 Lucro 2009 Lucro 2010 Lucro 2011

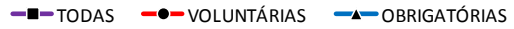

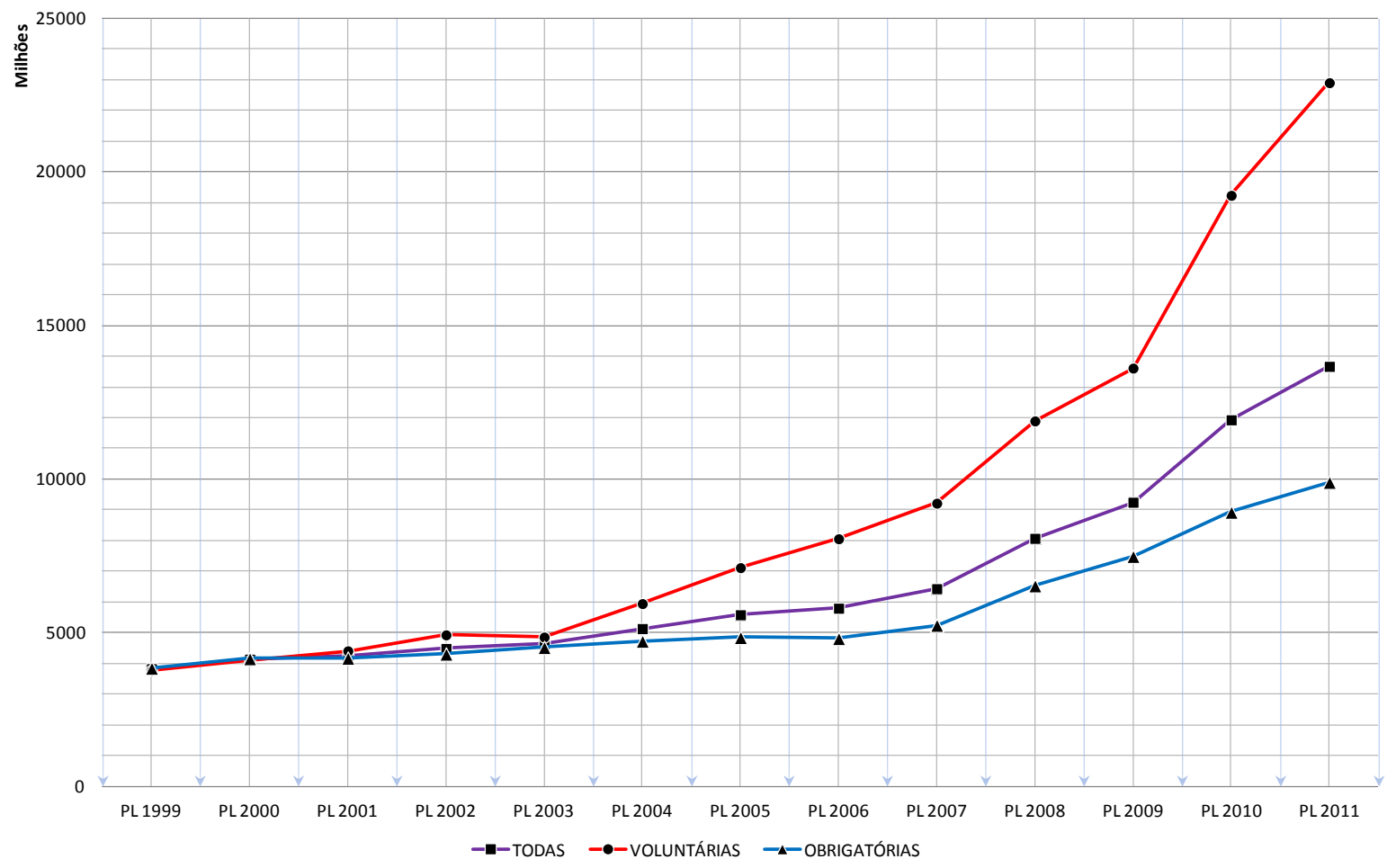

Gráfico 6 - Média do lucro líquido e do patrimônio líquido ao longo de 2000-2011 plotada para os grupos: TODAS, VOLUNTÁRIAS E OBRIGATÓRIAS.

Nota: lucro e patrimônio líquido plotados sem ajustes de escala.

Nota-se que a média aritmética do lucro de todas as empresas da amostra apresenta uma tendência de crescimento ao longo do período estudado, com destaque para o início da adoção completa que apresentou um elevado crescimento. Este crescimento pode ser explicado pelo 
CPC 37 - Adoção Inicial das Normas Internacionais de Contabilidade - que tem o objetivo de regular a aplicação integral das IFRS pela primeira vez. Há evidências empíricas (FIFIELD; FINNINGHAM; FOX; POWER; VENEZIANI, 2011) de que, a adoção pela primeira vez das IFRS implica em aumento do lucro líquido e, também, do patrimônio líquido das empresas também observado no gráfico 6. Coerentemente, Torres (2011) revela um aumento no patrimônio líquido em torno de 7,2\%, passando de $\mathrm{R} \$ 290$ bilhões para $\mathrm{R} \$ 310$ bilhões, sendo que o maior impacto positivo foi do ativo imobilizado.

Ao analisar o comportamento das médias de lucro e patrimônio líquido para os grupos TODAS, VOLUNTÁRIAS e OBRIGATÓRIAS, não se nota uma diferença significativa em termos de tendência das séries. Porém, é visível que as empresas voluntárias apresentam maior média tanto para lucro quanto para patrimônio, indicando que estas empresas são maiores em relação ao grupo de adoção obrigatória. Este resultado não é surpreendente, visto que, a adoção antecipada das IFRS é precedida de incentivos, entre eles, destaca-se o efeito tamanho das empresas identificado por Lima (2011).

A matriz de correlação para as variáveis $P, E A R N$ e $B V$ é apresentada na tabela 31 .

Tabela 30 - Correlação entre as variáveis do modelo de relevância

\begin{tabular}{l|c|c|}
\hline & $E A R N$ & $B V$ \\
\hline$P$ & $0,2949^{*}$ & $0,1417^{*}$ \\
\hline$E A R N$ & & $0,6680^{*}$ \\
\hline
\end{tabular}

Nota: Coeficientes de correlação de Pearson. * coeficiente significante estatisticamente a 0,05 . $P_{i t}$ é o preço da ação três meses após o encerramento do ano fiscal em $t$, deflacionado pelo preço em $t-1$ para a empresa $i ; B V_{i t}$ é o patrimônio líquido por ação da empresa $i$ para o período $t$, deflacionado pelo preço em $t-1 ; E A R N_{i t}$ é o resultado líquido por ação da empresa $i$ para o período $t$, deflacionado pelo preço em $t$ - 1 .

A matriz de correlação revela uma moderada correlação entre lucro e patrimônio líquido. Porém, ao analisar a correlação entre preço e as variáveis contábeis, nota-se uma associação maior e positiva entre preço e lucro.

A relevância da informação contábil é investigada por meio do modelo base (equação 37) e suas interações com as variáveis IFRS, ADR e BCGI. As estimativas são observadas na tabela seguinte. 
Tabela 31 - Estimativas geradas para o modelo de relevância, e suas variações

\begin{tabular}{|c|c|c|c|c|c|}
\hline & $\frac{P_{i t}}{P_{i t-1}}=\alpha_{0 t}+\beta_{1 t}$ & $\frac{B V_{i t}}{P_{i t-1}}+\beta_{2 t} \frac{E}{2}$ & $\frac{A R N_{i t}}{P_{i t-1}}+\varepsilon_{i t}$ & & \\
\hline & Original & IFRS & $\begin{array}{c}\text { IFRS e } \\
\text { ADR }\end{array}$ & $\begin{array}{c}\text { IFRS e } \\
\text { BCGI }\end{array}$ & $\begin{array}{c}\text { IFRS, ADR } \\
\text { e BCGI }\end{array}$ \\
\hline Variáveis & $\begin{array}{c}\text { Coeficientes } \\
\qquad / \mathbf{t}\end{array}$ & $\begin{array}{c}\text { Coeficientes } \\
\text { / t }\end{array}$ & $\begin{array}{c}\text { Coeficientes } \\
/ \mathrm{t}\end{array}$ & $\begin{array}{c}\text { Coeficientes } \\
\text { / t }\end{array}$ & $\begin{array}{c}\text { Coeficientes } \\
/ \mathrm{t}\end{array}$ \\
\hline$C$ & $\begin{array}{l}1,213 / \\
(4,57)^{*}\end{array}$ & $\begin{array}{l}1,171 / \\
(6,32)^{*}\end{array}$ & $\begin{array}{l}1,184 / \\
(1,07)^{*}\end{array}$ & $\begin{array}{l}1,179 / \\
(1,07)^{*}\end{array}$ & $\begin{array}{l}1,185 / \\
(1,07)^{*}\end{array}$ \\
\hline$E A R N$ & $\begin{array}{l}\mathbf{0 , 3 8 0} / \\
(7,68)^{*}\end{array}$ & $\begin{array}{l}0,357 / \\
(2,95)^{*}\end{array}$ & $\begin{array}{c}0,280 / \\
(2,36)^{* *}\end{array}$ & $\begin{array}{c}0,280 / \\
(2,36)^{* *}\end{array}$ & $\begin{array}{c}0,280 / \\
(2,36)^{* *}\end{array}$ \\
\hline$B V$ & $\begin{array}{c}-0,025 /(- \\
2,12)^{* *}\end{array}$ & $\begin{array}{c}-0,025 /(- \\
1,09)\end{array}$ & $\begin{array}{c}-0,025 /(- \\
1,08)\end{array}$ & $\begin{array}{c}-0,025 /(- \\
1,09)\end{array}$ & $\begin{array}{c}-0,025 /(- \\
1,09)\end{array}$ \\
\hline$E A R N * I F R S$ & & $\begin{array}{c}0,729 / \\
(2,31)^{* *}\end{array}$ & $\begin{array}{l}0,652 / \\
(3,37)^{*}\end{array}$ & $\begin{array}{l}2,175 / \\
(3,39)^{*}\end{array}$ & $\begin{array}{l}0,664 / \\
(3,38)^{*}\end{array}$ \\
\hline$B V * I F R S$ & & $\begin{array}{c}-0,178 /(- \\
1,37)\end{array}$ & $\begin{array}{l}0,153 / \\
(3,07)^{*}\end{array}$ & $\begin{array}{c}-0,042 /(- \\
0,26)\end{array}$ & $\begin{array}{l}0,151 / \\
\left(3,00^{*}\right)\end{array}$ \\
\hline$E A R N * I F R S * A D R$ & & & $\begin{array}{l}1,296 / \\
(6,03)^{*}\end{array}$ & & \\
\hline$B V * I F R S * A D R$ & & & $\begin{array}{c}-0,177 /(- \\
4,96)^{*}\end{array}$ & & \\
\hline$E A R N * I F R S * B C G I$ & & & & $\begin{array}{c}-1,981 /(- \\
1,61)\end{array}$ & \\
\hline$B V * I F R S^{*} B C G I$ & & & & $\begin{array}{c}0,240 / \\
(0,93)\end{array}$ & \\
\hline$E A R N * I F R S^{*} B C G I^{*} A D R$ & & & & & $\begin{array}{l}1,965 / \\
(5,33)^{*}\end{array}$ \\
\hline$B V * I F R S^{*} B C G I^{*} A D R$ & & & & & $\begin{array}{c}-0,275 /(- \\
4,39)^{*}\end{array}$ \\
\hline Indústria & Não & Sim & Sim & Sim & Sim \\
\hline N. Obs. & 743 & 743 & 743 & 743 & 743 \\
\hline $\mathrm{R}^{2}$ ajust. & 0,09 & 0,10 & 0,28 & 0,28 & 0,28 \\
\hline Estatística F & $3,77 *$ & $4,85 *$ & $9,67 *$ & $9,60 *$ & $9,67 *$ \\
\hline
\end{tabular}

Nota: Coeficientes $* * * \mathrm{e}^{* * *}$ são significantes estatisticamente a nível de 0,01, 0,05 e 0,10 respectivamente. As variáveis $E A R N$ e $B V$ foram deflacionadas por $P$ em $t$ - 1 .

O modelo de relevância permite investigar a qualidade da informação contábil, ou ainda, a sua relevância para o mercado de capitais. A informação contábil é relevante ao apresentar alguma associação com o valor de mercado do capital ou preço das ações (BARTH; BEAVER; LANDSMAN, 2001). 
Tomando como proxy da informação contábil a variável $E A R N$, pode-se afirmar que a mesma é relevante no contexto do mercado de capitais brasileiro, visto que a variável é significante estatisticamente a 0,01. Este resultado está coerente com outros estudos sobre a relevância da informação contábil no Brasil, tais como Lopes (2001), Almeida (2010) e Lima (2010).

Ao considerar a interação entre a dummy IFRS e EARN, a variável de interesse dada por $E A R N^{*} I F R S$ apresenta-se significante estatisticamente a 0,05 , além de exibir um coeficiente maior $(0,729>0,357)$ em relação à variável $E A R N$. A maior magnitude do coeficiente estimado para $E A R N^{*} I F R S$, permite afirmar que, esta variável possui maior peso na explicação das variações do preço das ações. De acordo com esta análise, a informação contábil passa a ser mais relevante no período da adoção completa das IFRS, coerente com a hipótese de pesquisa sobre a relevância da informação contábil.

No entanto, deve-se analisar a transição de GAAP juntamente com outros elementos que podem influenciar o conteúdo informacional da contabilidade, tais como, as práticas de Governança Corporativa (BCGI) e os incentivos para divulgar demonstrações contábeis de maior qualidade $(A D R)$.

O efeito conjunto de IFRS e $A D R$ dado pela variável $E A R N * I F R S * A D R$ confirma a relevância da informação contábil, e ainda revela um peso maior devido à magnitude do coeficiente estimado. Neste sentido, há uma maior associação entre preço das ações e lucro para as empresas que emitem ADRs na NYSE, especificamente no período 2010 e 2011.

A extensão desta análise para as variáveis IFRS e $B C G I$ apresenta um coeficiente negativo e não significante estatisticamente para $E A R N^{*} I F R S^{*} B C G I$, não fornecendo indícios de relevância da informação contábil no período da adoção completa, ao controlar pelo índice de Governança Corporativa (BCGI). Todavia, o efeito conjunto de IFRS, BCGI e ADR revela que a informação contábil é relevante para o período 2010 e 2011, destacando-se pela estimação de um coeficiente maior em relação aos anteriores.

Estes resultados fornecem evidências empíricas que corroboram as declarações do IASB a respeito dos benefícios associados à aplicação das IFRS. 


\subsection{Análise da Tempestividade da Informação Contábil}

A estatística descritiva e os coeficientes de correlação entre as principais variáveis do modelo de tempestividade já foram apresentados nas seções anteriores. Portanto, pode-se analisar diretamente as estimativas do modelo de tempestividade (tabela 32).

Tabela 32 - Estimativas geradas para o modelo de tempestividade, e suas variações

\begin{tabular}{|c|c|c|c|c|c|}
\hline & Original & IFRS & $\begin{array}{c}\text { IFRS e } \\
\text { ADR }\end{array}$ & $\begin{array}{c}\text { IFRS e } \\
\text { BCGI }\end{array}$ & $\begin{array}{c}\text { IFRS, ADR } \\
\text { e BCGI }\end{array}$ \\
\hline Variáveis & $\begin{array}{c}\text { Coeficientes } \\
\qquad / \mathbf{t}\end{array}$ & $\begin{array}{c}\text { Coeficientes } \\
\text { / t }\end{array}$ & $\begin{array}{c}\text { Coeficientes } \\
\qquad / \mathbf{t}\end{array}$ & $\begin{array}{c}\text { Coeficientes } \\
\text { / t }\end{array}$ & $\begin{array}{c}\text { Coeficientes } \\
/ \mathrm{t}\end{array}$ \\
\hline $\mathrm{C}$ & $\begin{array}{c}0,317 / \\
(2,37)^{* *}\end{array}$ & $\begin{array}{l}0,510 / \\
(4,10)^{*}\end{array}$ & $\begin{array}{l}0,492 / \\
(3,88)^{*}\end{array}$ & $\begin{array}{l}0,521 / \\
(4,12)^{*}\end{array}$ & $\begin{array}{l}0,495 / \\
(3,83)^{*}\end{array}$ \\
\hline$E A R N_{i t}$ & $\begin{array}{c}0,094 / \\
(0,94)\end{array}$ & $\begin{array}{c}0,018 / \\
(0,24)\end{array}$ & $\begin{array}{c}0,012 / \\
(0,17)\end{array}$ & $\begin{array}{c}0,005 / \\
(0,08)\end{array}$ & $\begin{array}{c}0,016 / \\
(0,22)\end{array}$ \\
\hline$E A R N_{i t}-E A R N_{i t-1}$ & $\begin{array}{c}0,223 / \\
(2,44) * *\end{array}$ & $\begin{array}{c}0,256 / \\
(1,98)^{* *}\end{array}$ & $\begin{array}{c}0,259 / \\
(2,01)^{* *}\end{array}$ & $\begin{array}{c}0,265 / \\
(2,05)^{* *}\end{array}$ & $\begin{array}{c}0,257 / \\
(1,99)^{* *}\end{array}$ \\
\hline$E A R N_{i t} * I F R S$ & & $\begin{array}{c}-1,231 /(- \\
2,63)^{*}\end{array}$ & $\begin{array}{l}-1,086 /(- \\
2,04)^{* *}\end{array}$ & $\begin{array}{c}-5,201 /(- \\
2,95)^{*}\end{array}$ & $\begin{array}{c}-1,107 /(- \\
2,07)^{* *}\end{array}$ \\
\hline$\left(E A R N_{i t}-E A R N_{i t-1}\right) * I F R S$ & & $\begin{array}{c}\mathbf{0 , 8 3 7} / \\
(\mathbf{1 , 8 4})^{* * *}\end{array}$ & $\begin{array}{c}1,363 / \\
(1,62)^{* * *}\end{array}$ & $\begin{array}{c}0,130 / \\
(0,10)\end{array}$ & $\begin{array}{c}0,991 / \\
(1,36)\end{array}$ \\
\hline$E A R N_{i t} * I F R S * A D R$ & & & $\begin{array}{c}-0,602 /(- \\
0,84)\end{array}$ & & \\
\hline$\left(E A R N_{i t}-E A R N_{i t-1}\right) * I F R S * A D R$ & & & $\begin{array}{c}-0,664 /(- \\
0,69)\end{array}$ & & \\
\hline$E A R N_{i t} * I F R S^{*} B C G I$ & & & & $\begin{array}{c}6,302 / \\
(2,19)^{* *}\end{array}$ & \\
\hline$\left(E A R N_{i t}-E A R N_{i t-1}\right) * I F R S * B C G I$ & & & & $\begin{array}{c}1,767 / \\
(0,72)\end{array}$ & \\
\hline$E A R N_{i t} * I F R S^{*} B C G I^{*} A D R$ & & & & & $\begin{array}{c}-0,802 /(- \\
0,72)\end{array}$ \\
\hline$\left(E A R N_{i t}-E A R N_{i t-1}\right) * I F R S^{*} B C G I^{*} A D R$ & & & & & $\begin{array}{c}-0,336 /(- \\
0,18)\end{array}$ \\
\hline Indústria & Não & Sim & Sim & Sim & Sim \\
\hline N. Obs. & 545 & 545 & 545 & 545 & 545 \\
\hline $\mathrm{R}^{2}$ ajust. & 0,03 & 0,03 & 0,03 & 0,03 & 0,03 \\
\hline Estatística F & $6,14 *$ & $1,71 * *$ & $1,60 * *$ & $1,73 * *$ & $1,57 * *$ \\
\hline
\end{tabular}

Nota: Coeficientes *, ** e *** são significantes estatisticamente a nível de 0,01, 0,05 e 0,10 respectivamente; $\operatorname{Ret}_{i t}$ é o retorno da ação para a empresa $i$ no ano $t ; E A R N_{i t}$ é o lucro por ação da empresa $i$ no ano $t ; E A R N_{i t-1}$ é o lucro por ação da empresa $i$ no ano $t$ - 1 . As variáveis de lucro são deflacionadas pelo preço em $t$ - 1 , com o propósito de reduzir problemas de escala. 
De forma geral, o modelo de tempestividade busca avaliar o papel da contabilidade, diante da percepção dos investidores a partir de eventos que alteram o valor da empresa. Portanto, as regressões de retorno podem ser usadas como base para testes de hipóteses sobre oportunidade, ao identificar mudanças no valor a partir das demonstrações contábeis (EASTON, 1999).

O modelo base revela que a informação contábil é oportuna, visto que a variável de interesse dada por $\left(E A R N_{i t}-E A R N_{i t-1}\right)$ é significante estatisticamente a 0,05 . Isto significa que, a contabilidade altera a percepção dos investidores diante de eventos que afetam o valor das empresas. Essa tempestividade é maior ao considerar o período da adoção completa, pois, além da variável $\left(E A R N_{i t}-E A R N_{i t-1}\right)^{*} I F R S$ ser significante estatisticamente a 0,10 , ela apresenta um coeficiente maior em relação à variável $\left(E A R N_{i t}-E A R N_{i t-1}\right)$. Este resultado demonstra que a informação contábil full IFRS é mais tempestiva, confirmando a hipótese de pesquisa sobre tempestividade da contabilidade durante 2010 e 2011.

Ao investigar o efeito combinado entre $\left(E A R N_{i t}-E A R N_{i t-1}\right)$ e $A D R$ na adoção completa das IFRS, o coeficiente estimado para a variável de interesse $\left(E A R N_{i t}-E A R N_{i t-1}\right) * I F R S * A D R$ revela que a informação não é tempestiva - coeficiente não significante estatisticamente, além de apresentar o sinal contrário. O mesmo resultado, exceto pelo sinal contrário, pode ser estendido para a análise combinada entre IFRS, ADR e BCGI - variável $\left(E A R N_{i t}-E A R N_{i t-}\right.$ 1)*IFRS*BCGI. E, por último, o efeito conjunto de IFRS, ADR e BCGI [(EARN $N_{i t}-E A R N_{i t-}$ 1)*IFRS*BCGI*ADR] também não revela maior oportunidade para as demonstrações contábeis.

Em resumo, diz-se que a informação contábil é mais tempestiva em 2010 e 2011, mas perde essa característica ao controlar por $A D R$ e $B C G I$. Almeida (2010) investigou a tempestividade das demonstrações contábeis no Brasil juntamente com dummies de $A D R$ e Níveis de Governança Corporativa da BM\&F BOVESPA, e também não detectou tal característica na análise ao considerar as práticas de governança corporativa.

Uma explicação para a ausência de tempestividade ao controlar por governança corporativa (BCGI e $A D R)$ pode ser atribuída ao maior conteúdo informacional das empresas que possuem práticas superiores de governança (LANZANA, 2004), notadamente no período de adoção completa das IFRS. A divulgação de relatórios contábeis intermediários, ou as 
previsões dos analistas de mercado elaboradas a partir de diversas fontes de informação, contribuíram para antecipar o lucro nos anos de adoção completa das IFRS. Logo, o lucro no período da adoção completa não revelou surpresa para o mercado, ao controlar por práticas de governança corporativa.

\subsection{Achados do Estudo de Evento na Adoção Inicial das IFRS}

Inicialmente, apresenta-se a estatística descritiva para as principais variáveis utilizadas nesta seção.

Tabela 33 -Estatísticas descritivas para as variáveis lucro líquido, patrimônio líquido e $C_{A A R_{-5+5}}$ segmentadas nos grupos TODAS, VOLUNTÁRIAS e OBRIGATÓRIAS

\begin{tabular}{l|cc|cc|cc}
\hline & \multicolumn{2}{c|}{ TODAS } & \multicolumn{2}{c|}{ VOLUNTÁRIAS } & \multicolumn{2}{c}{ OBRIGATÓRIAS } \\
\hline & $\mu$ & $\sigma$ & $\mu$ & $\sigma$ & $\mu$ & $\sigma$ \\
\hline$L L_{\text {BRGAAP }}$ & 920.828 & 2.092 .736 & 909.761 & 1.415 .329 & 925.165 & 2.313 .214 \\
\hline$P L_{\text {BRGAAP }}$ & 9.308 .769 & 21.609 .136 & 12.785 .077 & 33.631 .280 & 7.946 .431 & 14.558 .255 \\
\hline$L L_{I F R S}$ & 1.191 .192 & 2.327 .511 & 1.072 .770 & 1.721 .789 & 1.237 .601 & 2.534 .668 \\
\hline$P L_{I F R S}$ & 9.962 .754 & 22.656 .345 & 13.428 .357 & 34.971 .287 & 8.604 .613 & 15.540 .083 \\
\hline$L L_{I F R S-B R G A A P}$ & 270.364 & 1.327 .291 & 163.008 & 543.968 & 312.436 & 1.530 .257 \\
\hline$P L_{I F R S-B R G A A P}$ & 653.985 & 2.111 .580 & 643.279 & 1.682 .947 & 658.181 & 2.267 .958 \\
\hline CAR $5+5$ & 0,0065 & 0,0033 & $-0,0048$ & 0,0032 & 0,0106 & 0,0042 \\
\hline
\end{tabular}

Nota: Lucro líquido (LL) e patrimônio líquido (PL) em BRGAAP e IFRS foram obtidos nas Notas Explicativas das empresas no ano da adoção inicial, sendo que as diferenças correspondem aos ajustes de conciliação exigidos pelo CPC 37; diante dos valores do primeiro ano de adoção obrigatória e daqueles referentes ao balanço de abertura, foram coletados os valores do primeiro ano de adoção, os quais são apresentados em mil R\$; $C A R_{-5+5}$ corresponde ao retorno anormal acumulado para a janela de evento dado pela equação 44 .

Ao observar o grupo TODAS nota-se que o lucro médio em IFRS foi superior em torno de $29 \%$ em relação ao lucro BRGAAP. No caso do $P L$, o aumento foi de $7,03 \%$, revelando que a adoção integral das IFRS proporcionou impacto positivo nas demonstrações contábeis das empresas brasileiras. Neste processo de transição de GAAP, a tabela 33 revela que, em média, o lucro das empresas aumentou em $\mathrm{R} \$ 270.364$ mil, enquanto o $P L$ aumentou em $\mathrm{R} \$ 653.985$ mil.

Por outro lado, a análise do grupo VOLUNTÁRIAS revela um crescimento menor do lucro médio em IFRS, que foi de $17,92 \%$ ao comparar com o lucro BRGAAP. O PL também apresenta uma variação menor, de 5,03\%. No que diz respeito ao grupo OBRIGATÓRIAS, o crescimento do lucro e $P L$ é maior, os valores são de $33,77 \%$ e $8,28 \%$ respectivamente. Esta diferença implica em maior variação positiva na posição financeira e no desempenho das empresas que adotaram as IFRS obrigatoriamente. 
Contudo, deve-se investigar como o mercado reagiu diante de tais diferenças nos números contábeis, com o propósito de averiguar se realmente houve impacto econômico na transição de GAAP. Esta análise pode ser realizada mediante estudo do comportamento dos preços das ações diante de eventos específicos, neste caso, a divulgação pela primeira vez dos números full IFRS.

\subsubsection{Análise Gráfica e Teste dos Sinais}

Antes de iniciar o Teste de Sinais, pode-se visualizar o comportamento dos retornos anormais por meio de gráficos. Para isso, os gráficos a seguir foram construídos para a variável $\overline{C A R}$ definida na equação 44.

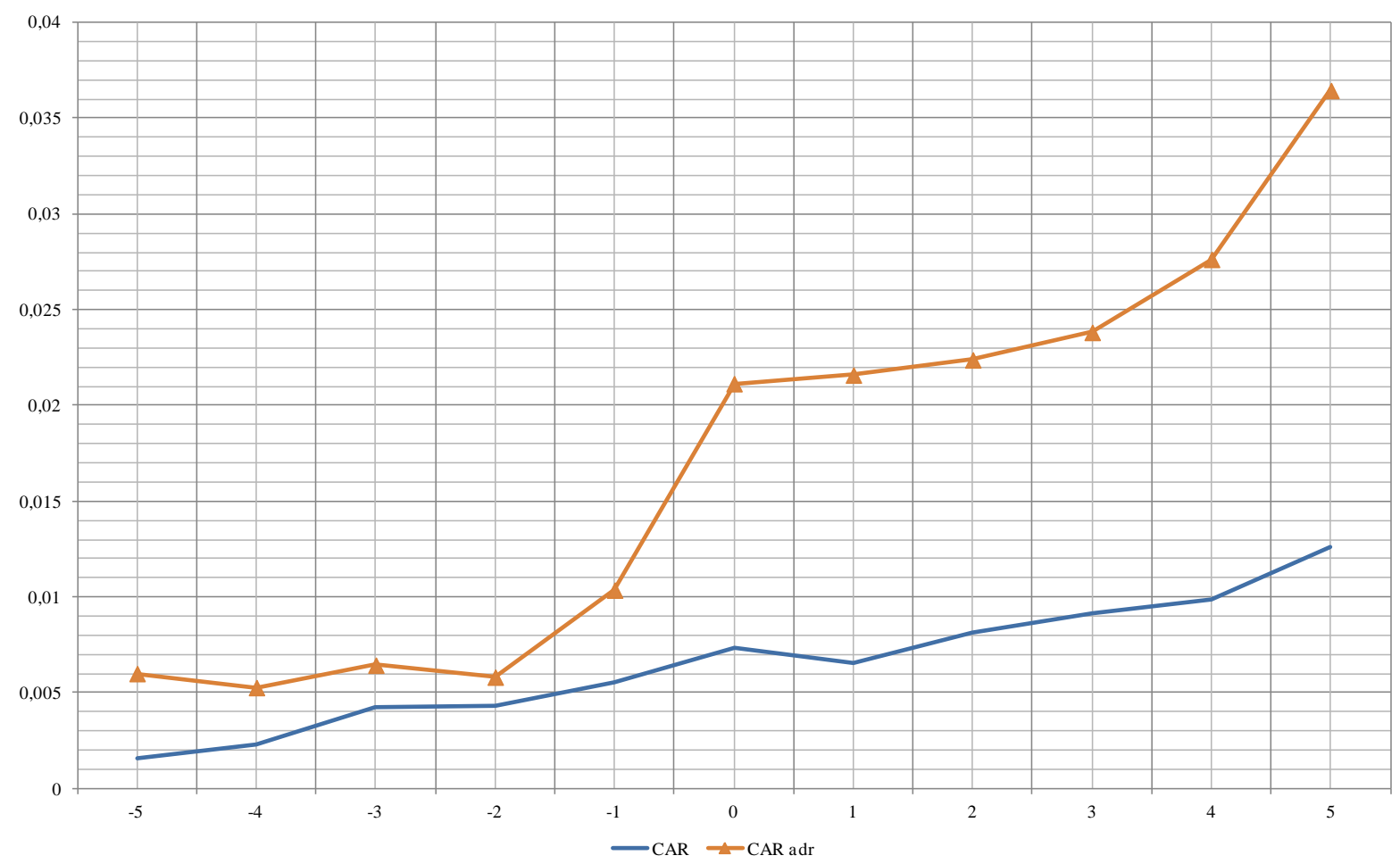

Gráfico 7 - $\overline{C A R}$ representa a agregação do retorno anormal acumulado no período $t$ para todas as ações $(n=101)$ e para aquelas que possuíam $\operatorname{ADR}\left(n_{1}=25\right)$ na janela de evento.

O gráfico 7 revela que as empresas com ADRs na NYSE possuem um $\overline{C A R}$ superior ao longo dos 11 dias observados em relação à amostra inicial. No entanto, a partir do dia que antecede a data de divulgação das demonstrações contábeis full IFRS, a diferença entre os dois grupos aumenta, principalmente na data do evento. Um aspecto que favorece o distanciamento entre 
os dois grupos deve-se ao conteúdo informacional das demonstrações contábeis. Vale lembrar que as empresas emitentes de ADRs divulgam suas demonstrações contábeis em USGAAP, e, por isso, espera-se que o nível de informação disponível para o investidor seja maior em relação às demais empresas do mercado brasileiro (ASSAF NETO, 2005). Além disso, as empresas que emitem ADRs possuem práticas superiores de governança corporativa (SILVEIRA, 2004; KPMG, 2009), implicando em maior proteção aos investidores e maior disclosure. Neste sentido, estas empresas possuem maiores incentivos para apresentar conteúdo informacional superior, explicando a reação exagerada dos investidores em termos de retorno anormal.

Por outro lado, o retorno anormal acumulado das empresas da amostra inicial, apesar de inferior, apresenta uma tendência de aumento ao longo da janela do evento. O gráfico 8 exibe o retorno anormal diário ou $\overline{D A R_{t}}$ dado pela equação 42 , e permite uma visualização mais adequada para a amostra completa.

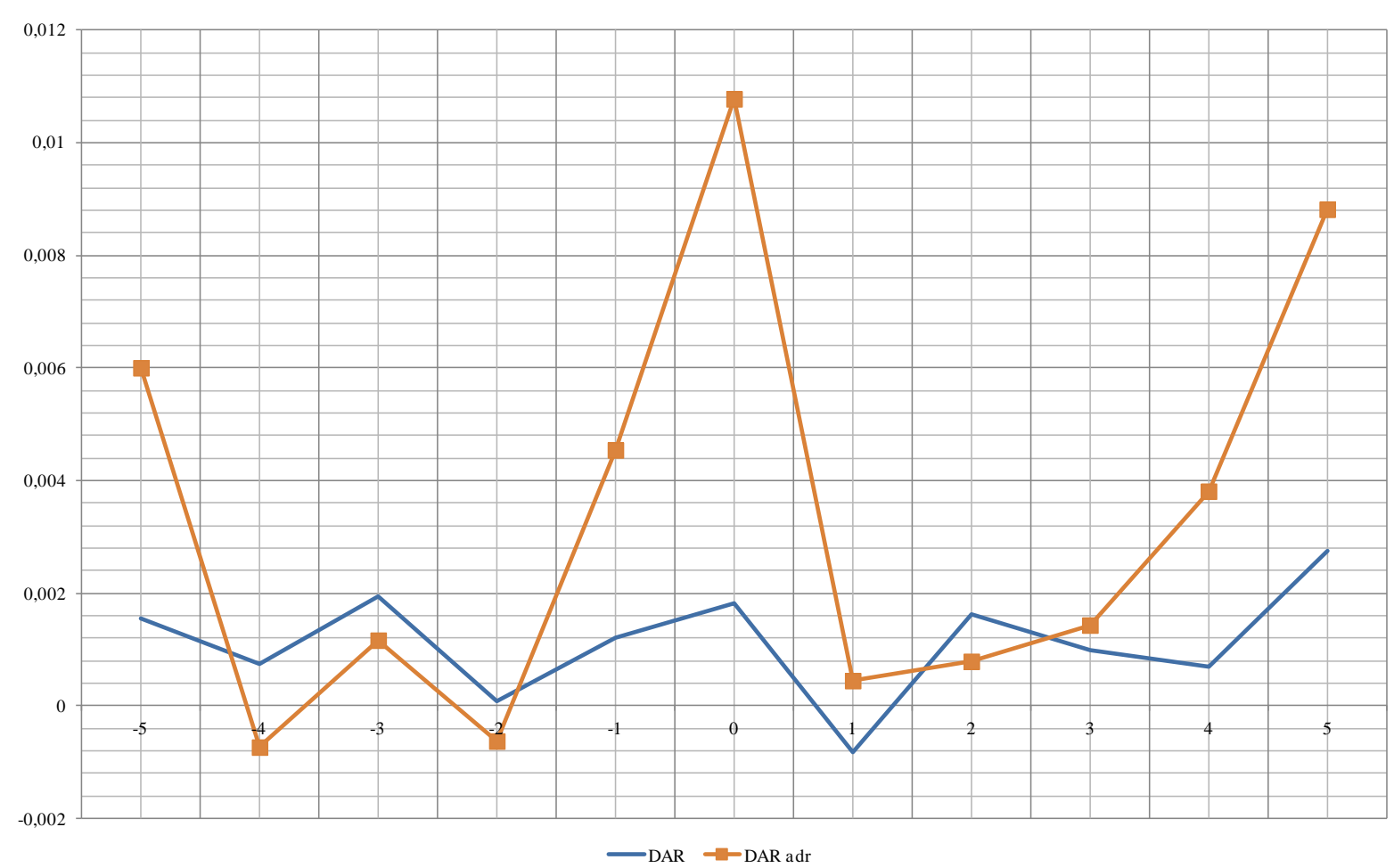

Gráfico 8 - $\overline{D A R_{t}}$ corresponde à média dos retornos anormais no período $\boldsymbol{t}$ para todas as ações $(\mathbf{n}=101) \mathrm{e}$ para aquelas que possuíam $\operatorname{ADR}\left(\mathrm{n}_{1}=25\right)$ na janela de evento.

Pelo gráfico 8 nota-se uma razoável oscilação na série de retorno anormal diário para a amostra completa. No entanto, dois dias anteriores à data de divulgação, há um aumento no 
retorno anormal, o que pode ser um indício de antecipação do evento estudado. Após a divulgação das demonstrações contábeis em IFRS (data 0) houve, em média, uma redução no retorno anormal diário. Ainda é possível afirmar que o mercado reagiu diante dos primeiros números em IFRS, principalmente ao considerar o conjunto de empresas que emitem ADRs. Estas evidências corroboram outros resultados obtidos a partir da metodologia de estudo de eventos, revelando que a contabilidade possui conteúdo informacional, mesmo que o mercado antecipe parte desta informação.

Os gráficos 9 e 10 revelam o comportamento dos retornos anormais acumulados e diários, respectivamente, ao separar as empresas da amostra de acordo com o ajuste de conciliação. Este ajuste deve ser publicado em consonância às exigências do CPC 37 (Adoção Inicial), sendo que o mesmo reflete a diferença entre o lucro publicado em IFRS e BRGAAP, ou seja, demonstra claramente o efeito da transição de GAAP no resultado.

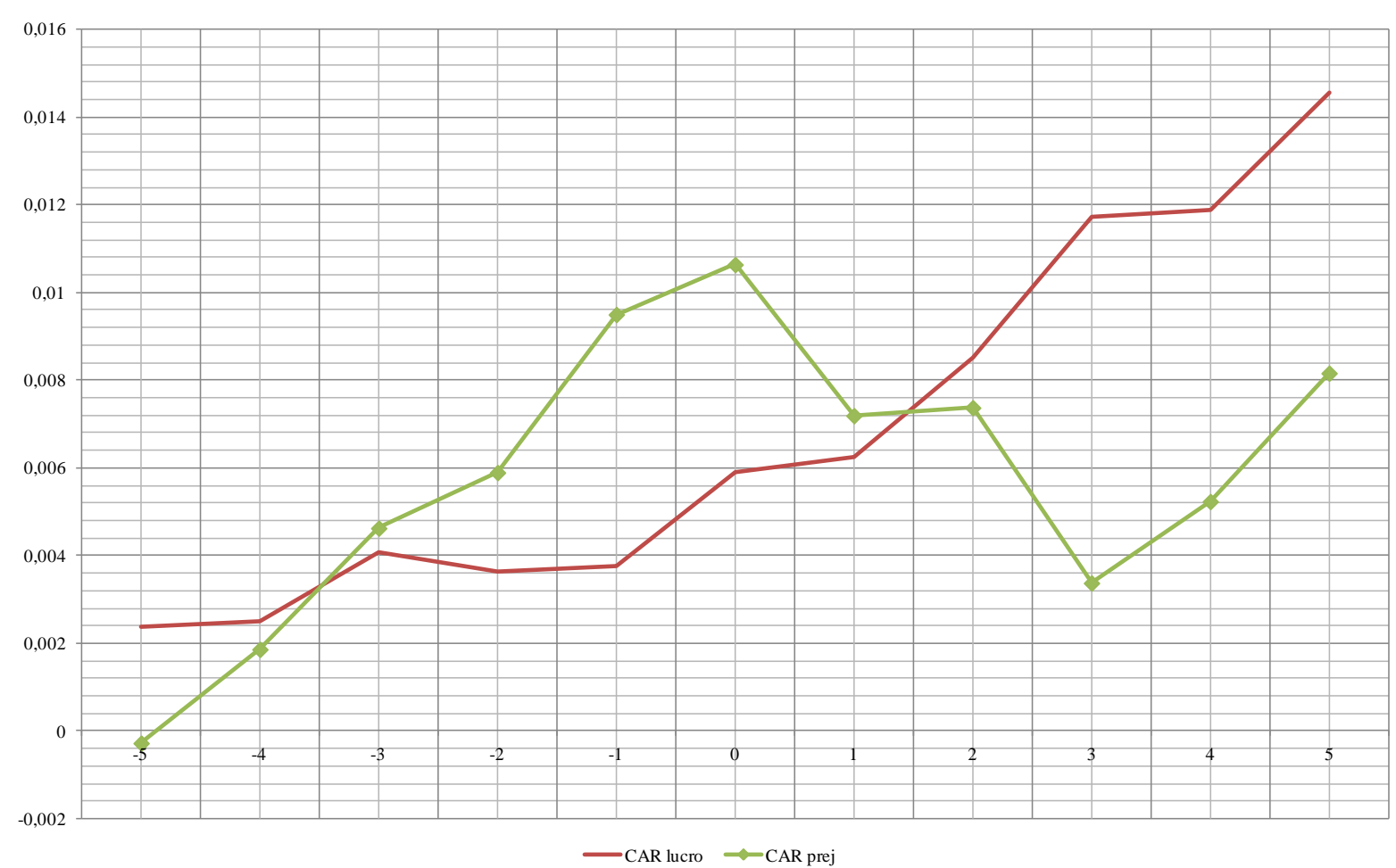

Gráfico 9 - $\overline{C A R}$ representa a agregação do retorno anormal acumulado no período $\mathbf{t}$ para as ações que apresentaram um ajuste positivo no resultado $\left(n_{2}=70\right)$, e para aquelas que apresentaram um ajuste negativo $\left(n_{3}=31\right)$ na janela de evento; o ajuste de conciliação corresponde à diferença entre os lucros em IFRS e BRGAAP, exigida pelo CPC 37 quando da adoção inicial das IFRS.

O retorno anormal acumulado das empresas que divulgaram um ajuste positivo apresenta uma tendência de aumento ao longo dos 11 dias observados, sendo mais acentuado entre os dias 1 
e 3. No caso das empresas de ajustes negativos, nota-se uma redução no retorno anormal acumulado após a data do evento, indicando que o mercado reagiu de forma negativa diante da redução na principal medida de desempenho das demonstrações contábeis. Soma-se a isso, a clara reversão no comportamento do retorno anormal entre os dois grupos após o evento, caracterizado por um aumento no grupo de ajuste positivo e uma redução no grupo de ajuste negativo.

Os resultados do gráfico 9 estão coerentes com os resultados de Horton e Serafeim (2009), visto que, as empresas que divulgaram ajuste negativo no resultado apresentaram retorno anormal negativo após a data do evento, consistente com a ideia de que, a administração posterga a comunicação de más notícias até estar em conformidade com as IFRS. Esses resultados indicam que a adoção completa das IFRS altera a crença dos investidores sobre o preço das ações.

No gráfico 10, o retorno anormal diário para as empresas de ajuste negativo demonstra claramente a reação do mercado, pois em média o retorno é positivo antes da divulgação das demonstrações contábeis full IFRS, e apresenta-se negativo após a divulgação dos números contábeis. O comportamento do retorno anormal revela que a informação contábil é útil para o mercado. 


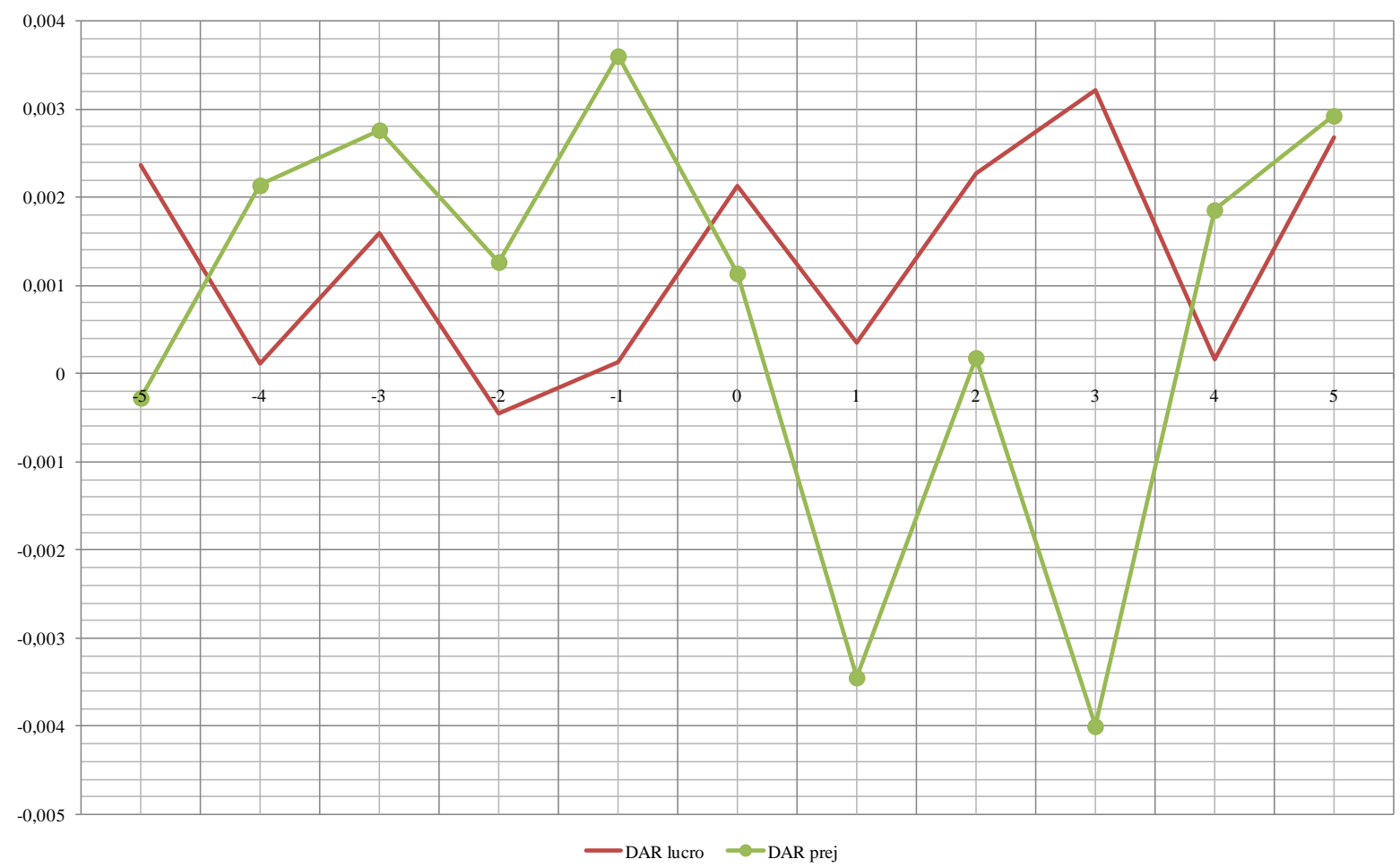

Gráfico $10-\overline{D A R}_{t}$ corresponde à média dos retornos anormais no período $t$ para as ações que apresentaram um ajuste positivo no resultado $\left(n_{2}=70\right)$, e para aquelas que apresentaram um ajuste negativo $\left(n_{3}=31\right)$ na janela de evento; $\boldsymbol{o}$ ajuste de conciliação corresponde à diferença entre os lucros em IFRS e BRGAAP, exigida pelo CPC 37 quando da adoção inicial das IFRS.

Os últimos gráficos apresentados (gráficos 11 e 12) referem-se à divisão da amostra em voluntárias e obrigatórias, ou seja, as empresas que adotaram as IFRS antecipadamente e o grupo que aplicou tais normas a partir das demonstrações contábeis anuais de 2010. O retorno anormal acumulado das empresas que adotaram obrigatoriamente mostra-se positivo e maior em relação ao grupo das empresas voluntárias. Porém, as empresas que adotaram antecipadamente apresentam um crescimento no $\overline{C A R}$ do dia -2 até o dia 3 , indicando que o mercado antecipou parte da informação e reagiu positivamente até o dia 3. 


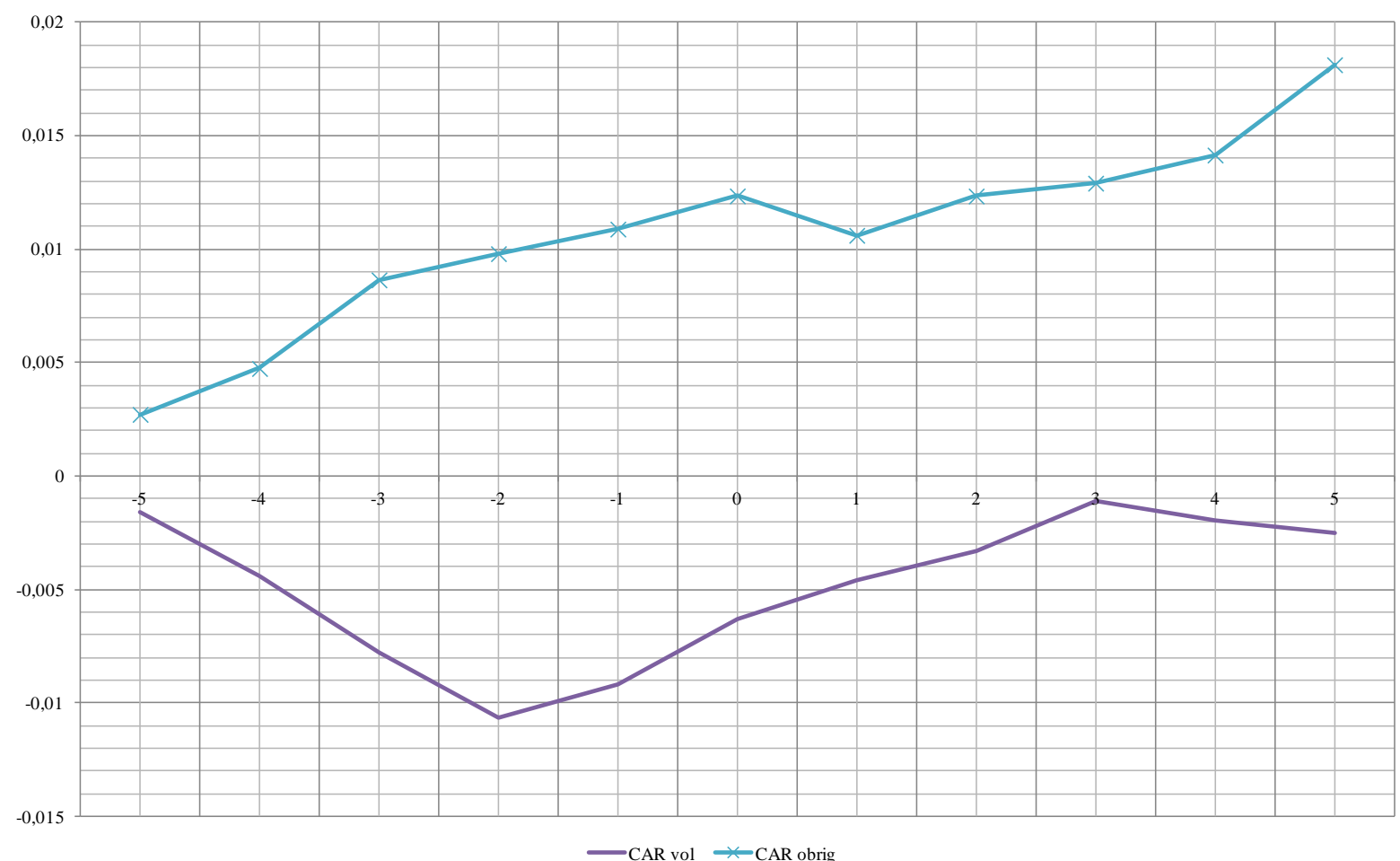

Gráfico 11 - $\overline{C A R}$ representa a agregação do retorno anormal acumulado no período $t$ para as ações de empresas que adotaram de forma voluntária as IFRS $\left(n_{4}=27\right)$, e para aquelas que adotaram obrigatoriamente $\left(n_{5}=74\right)$ na janela de evento.

Há explicações na literatura para uma reação positiva por parte do mercado diante da adoção não obrigatória das IFRS. Segundo Daske et al (2008) os efeitos do mercado de capitais são maiores para os precursores, pois estes aumentam o compromisso associado à adoção das IFRS e eliminam a dupla prática de divulgação. No gráfico a seguir, o retorno anormal diário demonstra mais claramente a reação do mercado. 


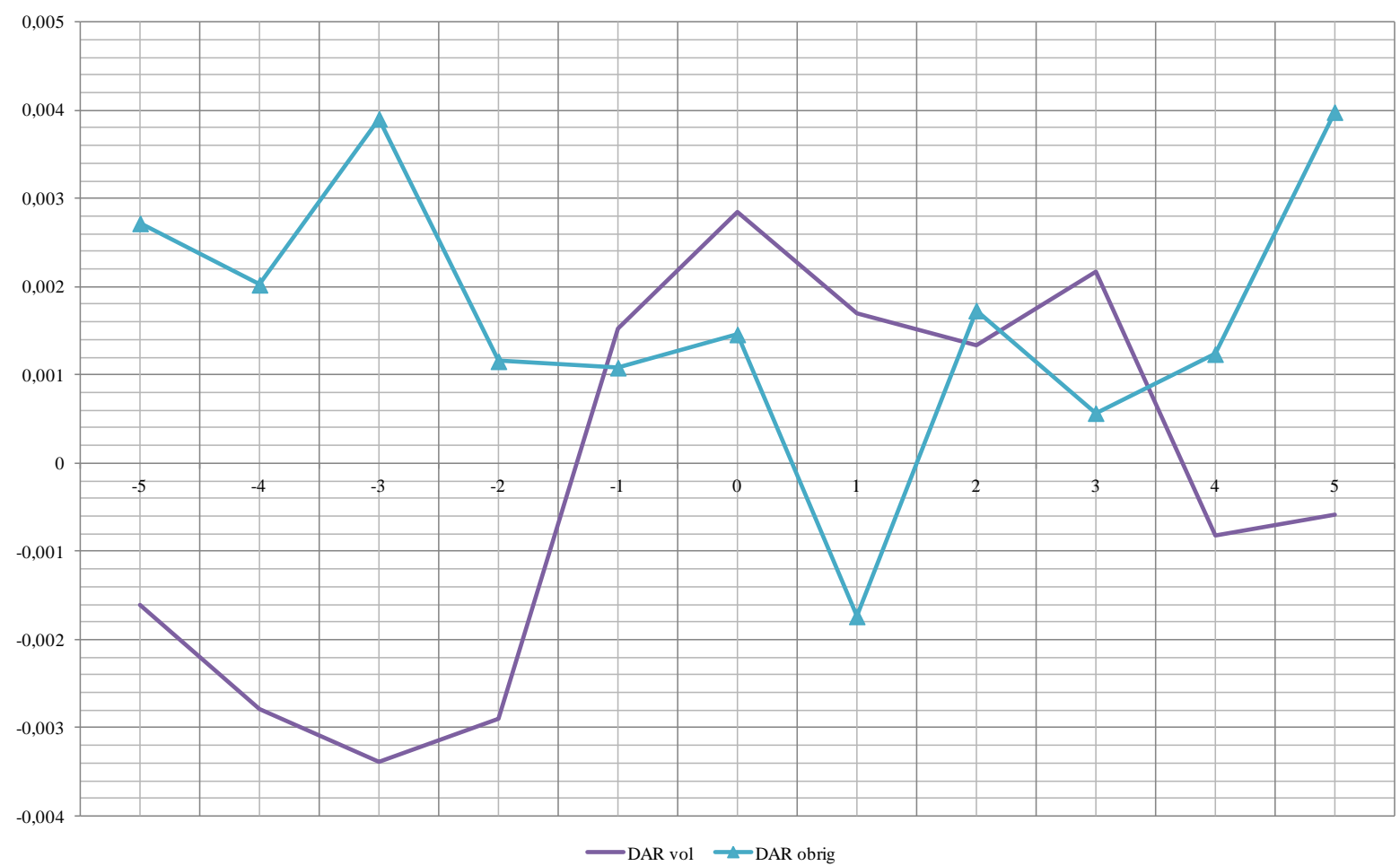

Gráfico 12 - $\overline{D A R_{t}}$ corresponde à média dos retornos anormais no período t para as ações de empresas que adotaram de forma voluntária as IFRS $\left(n_{4}=27\right)$, e para aquelas que adotaram obrigatoriamente $\left(n_{5}=74\right)$ na janela de evento.

O retorno anormal diário para as empresas voluntárias apresenta-se, em média, negativo antes do evento, sendo observada uma reversão após a divulgação das demonstrações contábeis full IFRS.

O estudo dos gráficos traz evidências acerca da reação do mercado diante das demonstrações contábeis em IFRS, mas deve ser complementada com uma análise robusta. Para isso, aplicase o teste de sinais para a série de retornos anormais acumulados $(\overline{C A R})$ obtida pela equação 44, e para a série de retornos diários $\left(\overline{D A R}_{t}\right)$ dada pela equação 42. Os resultados encontram-se na tabela a seguir. 
Tabela 34 - Teste de sinais para as séries de retorno anormal

\begin{tabular}{|c|c|c|c|c|c|c|c|c|c|c|c|c|}
\hline & \multicolumn{2}{|c|}{$\begin{array}{c}\text { Todas as empresas } \\
101)\end{array} \quad(\mathrm{n}=$} & \multicolumn{2}{|c|}{$\begin{array}{l}\text { Empresas com ADR } \\
\qquad\left(\mathrm{n}_{1}=15\right)\end{array}$} & \multicolumn{2}{|c|}{$\begin{array}{l}\text { Empresas com ajuste } \\
\text { positivo }\left(\mathrm{n}_{2}=70\right)\end{array}$} & \multicolumn{2}{|c|}{$\begin{array}{l}\text { Empresas com ajuste } \\
\text { negativo }\left(n_{3}=31\right)\end{array}$} & \multicolumn{2}{|c|}{$\begin{array}{l}\text { Empresas adoção vol. } \\
\qquad\left(\mathrm{n}_{4}=27\right)\end{array}$} & \multicolumn{2}{|c|}{$\begin{array}{l}\text { Empresas adoção obrig } \\
\qquad\left(\mathrm{n}_{5}=74\right)\end{array}$} \\
\hline & $\overline{D A R_{t}}$ & $\overline{C A R}$ & $\overline{D A R_{t}}$ & $\overline{C A R}$ & $\overline{D A R_{t}}$ & $\overline{C A R}$ & $\overline{D A R_{t}}$ & $\overline{C A R}$ & $\overline{D A R_{t}}$ & $\overline{C A R}$ & $\overline{D A R_{t}}$ & $\overline{C A R}$ \\
\hline-5 & $\mathbf{0 , 0 0 1 5} * *$ & $0,0015 * *$ & $0,0060 * *$ & $\mathbf{0 , 0 0 6 0} * *$ & $\mathbf{0 , 0 0 2 3} * *$ & $\mathbf{0 , 0 0 2 3} * *$ & $-0,0002 * *$ & $-0,0002 * *$ & $-0,0016$ & $-0,0016$ & $\mathbf{0 , 0 0 2 7} * *$ & $0,0027 * *$ \\
\hline-4 & 0,0007 & $0,0022 * *$ & $-0,0007$ & 0,0053 & 0,0001 & $0,0024 * *$ & 0,0021 & 0,0019 & $-0,0028$ & $-0,0043^{* *}$ & $\mathbf{0 , 0 0 2 0} * *$ & $0,0047 * *$ \\
\hline-3 & $0,0019 * *$ & $0,0042 * *$ & 0,0012 & $0,0064 * *$ & 0,0016 & $0,0040 * *$ & $0,0027 * *$ & 0,0046 & $-0,0034$ & $-0,0077 * *$ & $\mathbf{0 , 0 0 3 9} * *$ & $0,0086 * *$ \\
\hline-2 & $0,0001 * *$ & $0,0043 * *$ & $-0,0006$ & 0,0058 & $-0,0004 * *$ & $0,0036 * *$ & 0,0013 & 0,0059 & $-0,0028 * *$ & $-0,0106^{* * *}$ & 0,0012 & $0,0098 * *$ \\
\hline-1 & 0,0012 & $0,0055^{*} *$ & 0,0045 & $0,0103 * *$ & $0,0001 * *$ & $\mathbf{0 , 0 0 3 7} * *$ & 0,0036 & $0,0095^{* *}$ & 0,0015 & $-0,0091 * *$ & 0,0011 & $0,0108 * *$ \\
\hline 0 & $\mathbf{0 , 0 0 1 8 * *}$ & $0,0073 *$ & $\mathbf{0 , 0 1 0 7 * *}$ & $0,0211 * *$ & $0,0021 * *$ & $0,0059 * *$ & 0,0011 & $\mathbf{0 , 0 1 0 6 * *}$ & $0,0028 * *$ & $-0,0063 * *$ & 0,0015 & $0,0123 * *$ \\
\hline 1 & $-0,0008 * *$ & $0,0065 * *$ & 0,0005 & $\mathbf{0 , 0 2 1 5 * *}$ & 0,0003 & $0,0062 * *$ & $-0,0034 * *$ & 0,0072 & 0,0017 & $-0,0046 * *$ & $-0,0017 * *$ & $\mathbf{0 , 0 1 0 6} * *$ \\
\hline 2 & 0,0016 & $0,0081 * *$ & 0,0008 & $0,0223^{* *} *$ & $0,0022 * *$ & $0,0085 * *$ & $0,0002 * *$ & $0,0073 * *$ & 0,0013 & $-0,0032 * *$ & 0,0017 & $0,0123 * *$ \\
\hline 3 & 0,0010 & $0,0091 * *$ & 0,0014 & $\mathbf{0 , 0 2 3 8} * *$ & $0,0032 * *$ & $0,0117 * *$ & $-0,0039 * *$ & 0,0034 & $0,0021 * *$ & $-0,0011$ & $0,0005 * *$ & $0,0129 * *$ \\
\hline 4 & $0,0006 * *$ & $0,0098 * *$ & $0,0038 * *$ & $0,0276 * *$ & 0,0002 & $\mathbf{0 , 0 1 1 8} * *$ & $\mathbf{0 , 0 0 1 8} * *$ & $0,0052 * *$ & $-0,0008$ & $-0,0019$ & $0,0012 * *$ & $0,0141 * *$ \\
\hline 5 & $0,0027 * *$ & $0,0126 * *$ & $\mathbf{0 , 0 0 8 8} * *$ & $0,0364 * *$ & $0,0026 * *$ & $\mathbf{0 , 0 1 4 5 * *}$ & 0,0029 & $0,0081 * *$ & $-0,0005 * *$ & $-0,0025 * *$ & $0,0039 * *$ & $0,0181 * *$ \\
\hline
\end{tabular}

Nota: ** significante a nível de 5\%; esta tabela contém os resultados do teste de sinais para as séries: $\overline{D A R_{t}}$ que corresponde à média dos retornos anormais no período $t$, e

$\overline{C A R}$ que representa a agregação do retorno anormal acumulado no período $t$. Ambas são calculadas para todas as ações da amostra (n=101) e para os subgrupos: empresas com ADRs $\left(n_{1}=25\right)$; ajuste positivo no resultado $\left(n_{2}=70\right)$, ajuste negativo $\left(n_{3}=31\right)$, adoção voluntária $\left(n_{4}=27\right)$ e obrigatória $\left(n_{5}=74\right)$. 
Os resultados do teste de sinais revelam que o retorno anormal é positivo e significante estatisticamente a 0,05 na data do evento para todas as séries, exceto o $\overline{D A R_{t}}$ das empresas de ajuste negativo e daquelas que adotaram obrigatoriamente as IFRS. O $\overline{D A R_{t}}$ das empresas que adotaram voluntariamente as IFRS apresenta-se significante estatisticamente a 0,05 , porém o sinal é negativo. Para os casos de significância estatística, pode-se rejeitar a hipótese nula de que a proporção de retornos anormais positivos é igual à proporção de retornos anormais negativos. Assim, conclui-se que o mercado reagiu à divulgação das demonstrações contábeis full IFRS, confirmando a análise gráfica anterior.

Observa-se ainda a presença de alguns retornos anormais positivos e significativos a $0,05 \mathrm{em}$ alguns dias anteriores ao evento. Este resultado sinaliza a possibilidade de ocorrência de vazamento de informações e, segundo a metodologia de análise, pode caracterizar uma possível imperfeição do mercado. Por outro lado, a constatação de retornos anormais após o dia do evento pode indicar uma reação tardia do mercado, o que é observado para todos os grupos. Estes resultados apresentam indícios favoráveis à aceitação da hipótese de pesquisa sobre tempestividade. Portanto, as perspectivas de curto e longo prazo (seção 4.4) estão convergindo no que diz respeito à qualidade das demonstrações contábeis.

\subsubsection{Análise da Relevância e da Tempestividade na Janela de Evento}

O objetivo desta seção é investigar a tempestividade e relevância da informação contábil a partir da relação entre retorno anormal acumulado e os números contábeis divulgados na adoção inicial das IFRS. Os resultados estimados para avaliar a tempestividade da informação contábil encontram-se na tabela a seguir. 
Tabela 35 - Estimativas geradas para avaliar a tempestividade da informação contábil na janela de evento

\begin{tabular}{|c|c|c|c|c|c|c|}
\hline \multicolumn{7}{|c|}{$C A R_{-5+5}=\alpha_{0}+\beta_{1} E R N_{i}+\beta_{2} A D R_{i}+\beta_{3} V O L_{i}+\beta_{4} B C G I_{i}+\varepsilon$} \\
\hline & Coeficientes & $t$ & Coeficientes & $t$ & Coeficientes & $t$ \\
\hline$C$ & 0,13 & 0,693 & 0,16 & 0,891 & $-0,19$ & $-0,362$ \\
\hline$E R N^{I F R S-B R G A A P}$ & $\mathbf{0 , 6 0}$ & $2,738 *$ & & & & \\
\hline RERN & & & 0,289 & 0,652 & & \\
\hline$(E R N-E P S)$ & & & & & 0,14 & 0,659 \\
\hline$A D R$ & 0,16 & $2,676^{*}$ & 0,18 & $2,630 *$ & 0,17 & 0,767 \\
\hline$B C G I$ & $-0,15$ & $-0,337$ & $-0,21$ & $-0,489$ & 0,12 & 0,131 \\
\hline VOL & $-0,15$ & $-1,788 * * *$ & $-0,15$ & $-1,802 * * *$ & $-0,32$ & $-2,374 *$ \\
\hline Indústria & \multicolumn{2}{|c|}{ Não } & \multicolumn{2}{|c|}{ Não } & \multicolumn{2}{|l|}{ Sim } \\
\hline Empresas & \multicolumn{2}{|c|}{85} & \multicolumn{2}{|c|}{85} & \multicolumn{2}{|c|}{49} \\
\hline $\mathrm{R}^{2}$ ajust. & \multicolumn{2}{|c|}{0,07} & \multicolumn{2}{|c|}{0,05} & \multicolumn{2}{|c|}{0,04} \\
\hline Estatística F & \multicolumn{2}{|c|}{$2,54 * *$} & \multicolumn{2}{|c|}{$1,99 * * *$} & 1,1 & \\
\hline
\end{tabular}

Nota: Coeficientes *,** e *** são significantes estatisticamente a nível de 0,01, 0,05 e 0,10 respectivamente; $E R N^{I F R S-B R G A A P}$ para a equação 46 corresponde ao ajuste de conciliação divulgado quando da adoção inicial, ou seja, é a diferença entre lucro IFRS e BRGAAP; RERN são os resíduos da equação 47, os quais representam o componente não esperado, ou seja, aquilo que não foi previsto pelos analistas ou usuários da informação (HORTON; SERAFEIM, 2009); (ERN - EPS) é dado pela diferença $E R N^{I F R S-B R G A A P}$ e o lucro estimado $(E P S)$ para o ano da adoção inicial segundo previsão dos analistas; esta diferença é uma proxy para o componente não esperado do lucro; $C A R_{-5+5}$ corresponde ao retorno anormal acumulado para uma janela de evento de 5 dias antes e após a data de divulgação das demonstrações contábeis de acordo com as normas internacionais; $A D R$, ou American Depositary Receipt, é uma dummy que recebe 1 quando a empresa é emissora de ADRs e 0 caso contrário; VOL é uma dummy que assume 1 para casos de adoção voluntária e 0 caso contrário; BCGI é um índice de governança corporativa baseado em Lopes e Walker (2008).

Os resultados da tabela 35 sugerem que a informação contábil em IFRS revela nova informação para o mercado, dado que o coeficiente estimado para a variável $E R N^{I F R S-B R G A A P}$ é positivo e significante estatisticamente a 0,01 . Consequentemente, este resultado é favorável à aceitação da hipótese de tempestividade, indicando que a informação contábil em IFRS possui conteúdo informacional. No entanto, o mesmo não pode ser afirmado ao considerar as variáveis representativas do componente não esperado do lucro (RERN e ERN-EPS).

A variável $A D R$ revela uma relação positiva com o $C A R$, coerente com a análise gráfica e o teste dos sinais, exceto no último modelo (ERN-EPS). Este resultado comprova que as empresas emitentes de ADRs são beneficiadas com um retorno anormal acima da média no contexto da adoção inicial das IFRS. O mesmo não pode ser afirmado para as empresas que adotaram as IFRS antecipadamente ou voluntariamente, visto que, apesar do coeficiente estimado para VOL ser significante estatisticamente nos três modelos analisados, o mesmo apresenta sinal negativo, ou seja, a adoção antecipada é associada a um retorno anormal negativo. 
Para avaliar a relevância da informação contábil na janela do evento de 11 dias, pode-se aplicar a equação 49, também baseada em Horton e Serafeim (2009).

Tabela 36 - Estimativas geradas para avaliar a relevância da informação contábil na janela de evento

\begin{tabular}{|c|c|c|c|c|c|c|c|c|}
\hline & \multicolumn{2}{|c|}{ BRGAAP } & \multicolumn{2}{|l|}{ IFRS } & \multicolumn{2}{|c|}{ IFRS-BRGAAP } & \multicolumn{2}{|c|}{ Equação 49} \\
\hline & Coeficientes & $\mathrm{t}$ & Coeficientes & $\mathrm{t}$ & Coeficientes & $t$ & Coeficientes & $\mathrm{t}$ \\
\hline C & 1,53 & $4,83^{*}$ & 1,51 & $4,82^{*}$ & 1,62 & $4,97 *$ & 1,52 & $4,50 *$ \\
\hline$L L_{B R G A A P}$ & 0,46 & 0,71 & & & & & 0,44 & 0,65 \\
\hline$P L_{B R G A A P}$ & 0,15 & 1,35 & & & & & 0,15 & 1,27 \\
\hline$L L_{I F R S}$ & & & 0,33 & 0,79 & & & & \\
\hline$P L_{I F R S}$ & & & 0,15 & 1,32 & & & & \\
\hline$L L_{\text {IFRS-BRGAAP }}$ & & & & & 0,66 & 1,56 & 0,14 & 0,27 \\
\hline$P L_{\text {IFRS-BRGAAP }}$ & & & & & $-0,05$ & $-0,11$ & 0,09 & 0,17 \\
\hline$A D R$ & $-0,21$ & $-1,37$ & $-0,19$ & $-1,31$ & $-0,23$ & $-1,32$ & $-0,19$ & $-1,31$ \\
\hline$B C G I$ & 0,28 & 0,52 & 0,32 & 0,61 & 0,43 & 0,69 & 0,29 & 0,54 \\
\hline$V O L$ & 0,12 & 0,45 & 0,15 & 0,61 & 0,31 & 1,16 & 0,13 & 0,46 \\
\hline Indústria & Sim & & Sim & & Sim & & Sim & \\
\hline Empresas & 85 & & 85 & & 85 & & 49 & \\
\hline $\mathrm{R}^{2}$ ajust. & 0,14 & & 0,14 & & 0,02 & & 0,11 & \\
\hline Estatística F & $1,65^{* *}$ & & $1,65^{* * *}$ & & 1,06 & & 1,46 & \\
\hline
\end{tabular}

Nota: Coeficientes *, ** e *** são significantes estatisticamente a nível de $0,01,0,05$ e 0,10 respectivamente; $L L_{B R G A A P}$ e $P L_{B R G A A P}$ são, respectivamente, o lucro e patrimônio líquido segundo as normas contábeis vigentes antes da adoção completa das IFRS no ano da adoção completa; $L L_{I F R S} e P L_{I F R S}$ são, respectivamente, o lucro e o patrimônio líquido segundo as IFRS no ano inicial da adoção completa das IFRS; $L L_{\text {IFRS-BRGAAP }}$ P $P L_{\text {IFRS-BRGAAP }}$ são, respectivamente, os ajustes de conciliação de lucro e patrimônio líquido divulgados na adoção inicial por exigência do CPC 37; ADR, ou American Depositary Receipt, é uma dummy que recebe 1 quando a empresa é emissora de ADRs e 0 caso contrário; VOL é uma dummy que assume 1 para casos de adoção voluntária e 0 caso contrário; BCGI é um índice de governança corporativa baseado em Lopes e Walker (2008).

A tabela 36 não revela resultados que permitam afirmar que a informação contábil é relevante para o mercado de capitais, pois as variáveis contábeis não foram significantes estatisticamente. Este resultado não é favorável à aceitação da hipótese de relevância da informação contábil em IFRS, porém deve-se ressaltar que a tabela 36 revela evidências para a janela de evento composta por 11 dias, ou seja, análise da relevância para o curto prazo. Os achados da seção 4.4 revelam que a informação em IFRS é relevante para o período de adoção completa (2010 e 2011).

\subsection{A Relação entre Custo de Capital e Qualidade da Informação Contábil}

Diante da multidimensionalidade da qualidade da informação contábil (FRANCIS; OLSSON; SCHIPPER, 2008) adotou-se a estratégia denominada portfolio approach (BARTH et al, 2006) para investigar as consequências da transição de GAAP (BRGAAP para IFRS) na 
qualidade das demonstrações contábeis. Por isso, modelos de relevância, tempestividade, conservadorismo e gerenciamento de resultados foram aplicados.

Todavia, para avaliar a relação entre a qualidade da informação contábil e o custo de capital próprio na adoção completa das IFRS, deve-se assumir uma proxy de qualidade de informação contábil. Considerando a existência de vários estudos sobre a relação entre gerenciamento de resultados e custo de capital (ABOODY; HUGHES; LIU, 2005; FRANCIS et al 2005; NARDI, 2008), decidiu-se adotar como variável representativa da qualidade da informação contábil os accruals discricionários dados pelo modelo KS. Portanto, no contexto da adoção completa das IFRS, o modelo pode ser definido como:

$$
\begin{aligned}
& r_{P E G_{i t}}=\alpha_{0}+\alpha_{1}\left|A D_{K S i t}\right|+\alpha_{2}\left|A D_{K S i t}\right| * I F R S_{i t}+\alpha_{3} S I Z E_{i t}+\alpha_{4} D E B T_{i t}+\alpha_{5} C F_{i t}+\alpha_{6} A D R_{i t}+ \\
& +\alpha_{7} B C G I_{i t}+\alpha_{8} V O L_{i t}+\varepsilon_{i t}
\end{aligned}
$$

Equação 58

onde $r_{P E G i t}$ é custo e capital próprio da empresa $i$ no ano $t$ estimado pela equação modelo Price Earnings Growth - PEG; ADR, ou American Depositary Receipt, é uma dummy que recebe 1 quando a empresa é emissora de ADR e 0 caso contrário; SIZE é o logaritmo natural do ativo total da empresa $i$ para o período $t$; e $B C G I$ é um índice de governança corporativa; $D E B T$ é o total de dívidas dividido pelo total do patrimônio líquido da empresa $i$ para o período $t ; C F$ é o fluxo de caixa operacional líquido da empresa $i$ para o período $t ; A D_{K S}$ é uma proxy de gerenciamento de resultados dada pela equação 30, da empresa $i$ para o período $t$.

A relação esperada entre custo de capital e accruals discricionários é positiva, pois quanto maior o nível de gerenciamento de resultado maior será o custo de capital da empresa. No entanto, espera-se que a adoção completa das IFRS represente um incentivo para redução da discricionariedade voltada para gerenciamento de resultados, coerente com a visão de um conjunto de normas de alta qualidade que dificulta tais práticas (NELSON, et al 2002; MAINES, et al 2003; AGOGLIA; DOUPNIK; TSAKUMIS, 2011). Portanto, é esperado que o coeficiente $\alpha_{1}$ seja positivo, revelando uma associação positiva entre GR e custo de capital, e que o coeficiente $\alpha_{2}$ seja negativo, sinalizando que o nível de accruals discricionários é menor quando da adoção completa das IFRS. Neste sentido, espera-se que $\alpha_{1}$ seja maior que 
$\alpha_{1}+\alpha_{2}$, indicando que o período de adoção completa possui um efeito negativo no custo de capital das empresas.

Os resultados podem ser observados na tabela a seguir.

Tabela 37 - Estimativas geradas para avaliar a relação entre custo de capital próprio e gerenciamento de resultado conforme equação 58

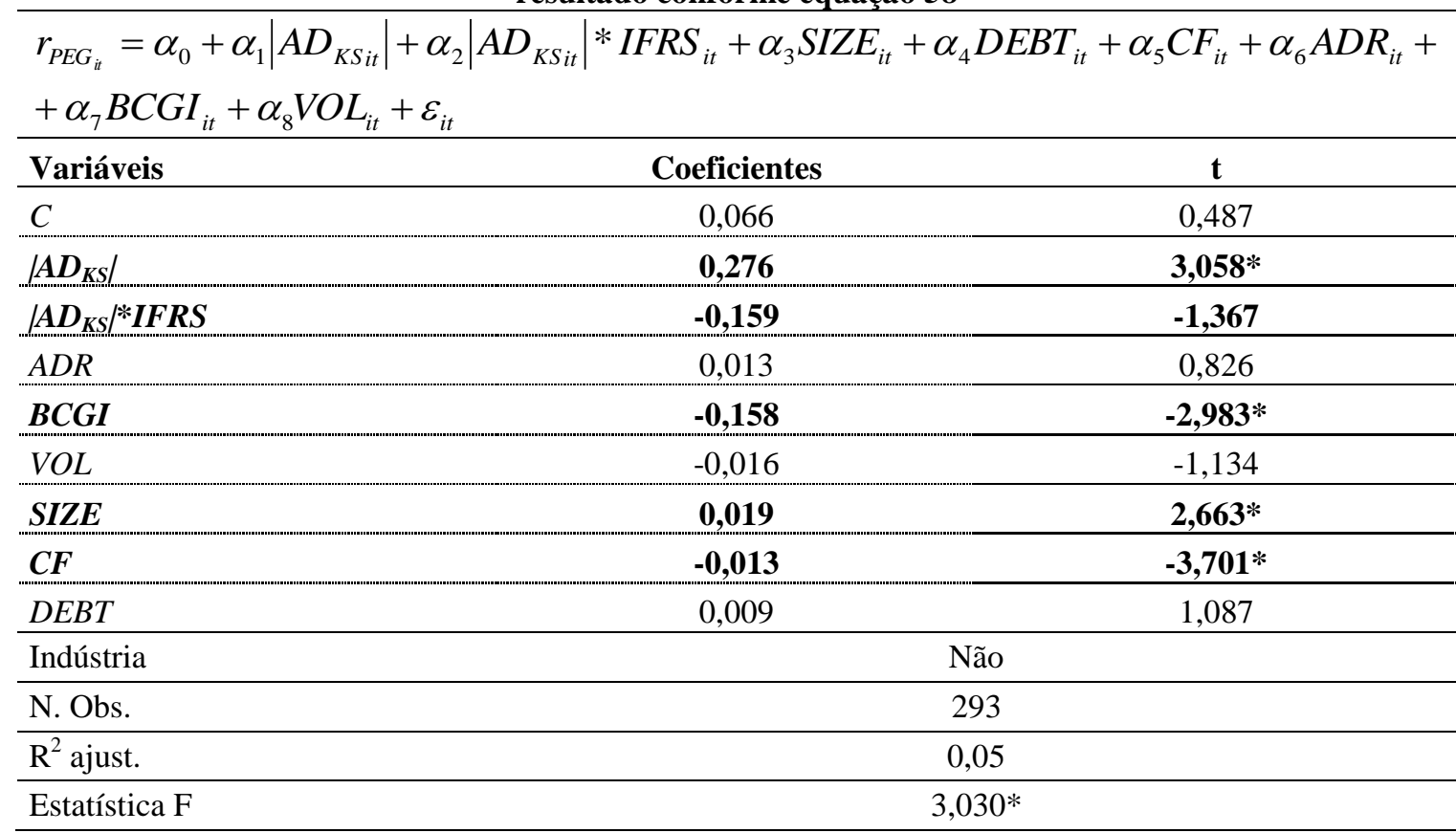

Nota: Coeficientes *,** e *** são significantes estatisticamente a nível de 0,01, 0,05 e 0,10 respectivamente; $r_{P E G i t}$ é custo e capital próprio da empresa $i$ no ano $t$ estimado pela equação modelo Price Earnings GrowthPEG; $A D R$ é uma dummy que recebe 1 quando a empresa é emissora de ADR e 0 caso contrário; SIZE é o logaritmo natural do ativo total da empresa $i$ no ano $t$; e $B C G I$ é um índice de governança corporativa; $D E B T$ é o total de dívidas dividido pelo total do patrimônio líquido da empresa $i$ no ano $t$; $C F$ é o fluxo de caixa operacional líquido da empresa $i$ no ano $t ;\left|A D_{K S}\right|$ é uma proxy de gerenciamento de resultados dada pela equação 30, da empresa $i$ no ano $t$.

Os resultados da equação 58 confirmam a relação positiva entre GR e custo de capital próprio, ou seja, quanto maior o nível de accruals discricionários, proxy para gerenciamento de resultados, maior o custo de capital próprio. Neste sentido, o efeito das práticas de gerenciamento no custo de capital próprio pode ser representado pelo coeficiente $\alpha_{1}(0,276)$.

Pode-se investigar o papel das IFRS por meio da interação entre $\left|A D_{K S}\right|$ e IFRS, que revela o efeito dos accruals discricionários no custo de capital próprio durante o período de adoção completa: 2010 e 2011. As variáveis $\left|A D_{K S}\right|$ e $\left|A D_{K S}\right|^{*} I F R S$ indicam uma redução no efeito dos accruals discricionários sobre o custo de capital próprio, visto que a soma dos coeficientes $\alpha_{1}$ e $\alpha_{2}(0,276+(-0,159)=0,117)$ é menor que $\alpha_{1}(0,276)$. Neste sentido, a influência do gerenciamento de resultado no custo de capital próprio é menor, sinalizando uma possível 
redução nas práticas de gerenciamento, coerente com o cenário de aumento da qualidade da informação contábil ${ }^{46}$. Portanto, estes resultados trazem evidências de que, o aumento da qualidade da informação contábil no período da adoção completa, contribuiu para redução do custo de capital próprio. No entanto, deve-se fazer uma ressalva quanto ao coeficiente estimado para a variável $\left|A D_{K S}\right| * I F R S$, que possui um $p$-value de 0,1724 e não é significante estatisticamente. Assim, a sua influência sobre o custo de capital próprio pode ser fraca, o que pode ser confirmado por uma continuação do estudo abrangendo os anos vindouros de adoção de IFRS. Com isso, a hipótese de que o processo de convergência às IFRS provocou uma redução no custo de capital próprio pode ser aceita com algumas ressalvas.

É interessante notar que a variável BCGI (tabela 38) apresenta sinal negativo, indicando que as práticas de governança corporativa contribuem para reduzir o custo de capital próprio das empresas, coerente com Lopes (2008). O autor explica que, em cenários de informação assimétrica e alta concentração de propriedade, os investidores (acionistas minoritários) são receosos quanto às ações dos administradores (controlados pelos acionistas majoritários), que tem poder para expropriá-los. Neste sentido, as empresas interessadas em financiar seus projetos de investimento por meio de fontes de capital externa devem se comprometer com práticas superiores de governança corporativa, com o propósito de reduzir os custos de agência e, consequentemente, o custo de capital.

\subsection{Análise Adicional e Testes de Robustez}

A partir da recomendação de Kothari (2001) em separar os componentes esperado e não esperado do lucro ou prejuízo, estimou-se o componente não esperado a partir da diferença entre o lucro observado para o período $t$ e a sua previsão segundo analistas de mercado. $\mathrm{O}$ objetivo é avaliar o efeito surpresa ou não esperado do lucro no mercado de capitais. Assim, o efeito surpresa foi adicionado aos modelos de relevância e tempestividade, mas os resultados não foram superiores em relação aos resultados reportados nas seções 4.4 e 4.5.

\subsubsection{Modelo de Diferenças em Diferenças para Custo de Capital Próprio}

\footnotetext{
${ }^{46}$ De acordo com a literatura de gerenciamento de resultado, há uma relação negativa entre qualidade da informação contábil e accruals discricionários. Sendo assim, uma redução no nível de accruals discricionários pode ser explicada por um aumento na qualidade da informação contábil.
} 
Segundo Bertrand et al (2004), a abordagem DD pode apresentar o problema de correlação serial (espaço e tempo). Para avaliar o problema de correlação serial, pode-se excluir o período de transição (2009 e 2010) e verificar se as estimativas são consistentes, inclusive o termo de interação "Adotantes obrigatórios IFRS x Período pós adoção" que revela o efeito da adoção completa no custo de capital próprio.

Tabela 38 - Estimativas geradas para a equação 15 - custo de capital próprio pelo modelo de diferenças em diferenças, excluindo 2009 e 2010.

\begin{tabular}{lcc}
\hline Variáveis & Coeficientes & $\mathbf{t}$ \\
\hline$C$ & 0,2591 & $1,67 * * *$ \\
\hline SIZE & $-0,006$ & $-0,09$ \\
\hline RETVAR & 0,0040 & $1,89 * * *$ \\
\hline LEV & $-0,0719$ & $-0,84$ \\
\hline ADR & 0,0285 & 1,52 \\
\hline BCGI & $-0,2169$ & $-4,53^{*}$ \\
\hline $\begin{array}{l}\text { Adotantes } \\
\text { obrigatórios IFRS }\end{array}$ & 0,0465 & $2,18^{* *}$ \\
\hline Período pós adoção & 0,0554 & $1,85^{* * *}$ \\
\hline $\begin{array}{l}\text { Adotantes } \\
\text { obrigatórios IFRS } \boldsymbol{x}\end{array}$ & $\mathbf{- 0 , 0 5 1 5}$ & $\mathbf{- 2 , 9 5 *}$ \\
Período pós adoção & \multicolumn{3}{c}{332} \\
\hline N. Obs. & \multicolumn{2}{c}{0,04} \\
\hline $\mathrm{R}^{2}$ ajust. & \multicolumn{2}{c}{$3,02^{*}$} \\
\hline Estatística $\mathrm{F}$ & \\
\hline
\end{tabular}

Nota: A variável “adotantes obrigatórios IFRS” é uma dummy que assume 1 quando a empresa adotou IFRS obrigatoriamente e 0 caso contrário. Ela revela a diferença em termos de custo de capital entre os dois grupos (adoção obrigatória versus adoção voluntária). A variável “período pós adoção" é uma dummy que recebe 1 para 2011. Ela mostra a tendência de aumento ou diminuição de custo de capital, ou seja, é um efeito temporal. A variável "adotantes obrigatórios IFRS x período pós adoção" é fruto da multiplicação das dummies anteriores e revela o verdadeiro impacto da adoção obrigatória no custo de capital, controlando o efeito temporal.

Coeficientes *,** e*** são significantes estatisticamente a nível de 0,01, 0,05 e 0,10 respectivamente.

Após exclusão dos anos 2009 e 2010, os resultados revelam que o termo de interação (0,0515) é significante estatisticamente. Portanto, os resultados permanecem robustos após controlar pelo problema de correlação serial.

\subsubsection{Estimativas pelo GMM Sistêmico}

No contexto da análise econométrica um dos problemas observados na literatura é a presença da endogeneidade (LARCKER; RUSTICUS, 2010). Ao observar uma correlação entre as variáveis independentes e os termos de erro, uma das propriedades do método dos Mínimos Quadrados Ordinários - MQO deixa de ser atendida, implicando em casos de endogeneidade. Como resultado, os coeficientes estimados pelo método MQO serão viesados e inconsistentes. 
Diante disso, pode-se utilizar o método de variáveis instrumentais ou instrumental variables IV, que, segundo Larcker e Rusticus (2010), requer que o pesquisador encontre variáveis instrumentais correlacionadas com a variável endógena, porém não correlacionadas com o termo de erro. No entanto, a identificação de variáveis instrumentais que atendam essas condições não é tarefa simples, e representa um grande desafio para as pesquisas empíricas no campo da contabilidade ${ }^{47}$.

Alternativamente, pode-se utilizar o método denominado GMM (Generalized Method of Moments) Sistêmico usado por Brito (2010) e Gabriel (2011), em função da dificuldade em encontrar variáveis instrumentais. O GMM Sistêmico, desenvolvido por Arellano e Bover (1995) e Blundel e Bond (1998), adota um sistema de equações em primeiras diferenças e equações em níveis. Neste sentido, as primeiras diferenças defasadas das séries são usadas como instrumentos nas equações em níveis; e, por sua vez, os níveis defasados das séries são usados como instrumentos nas equações em primeiras diferenças (GABRIEL, 2011).

Assim, o GMM Sistêmico permite o tratamento do problema de endogeneidade, mesmo que instrumentos estritamente exógenos para os regressores não estejam disponíveis (BRITO, 2010). Todavia, a validade das estimativas está condicionada ao atendimento dos seguintes pressupostos, extraídos de Brito (2010) e Gabriel (2011): i) não correlação das defasagens superiores a um período dos regressores endógenos com as primeiras diferenças dos erros. Segundo Gabriel (2011), a suposição é válida se a estatística de autocorrelação de primeira ordem $(\mathrm{ml})$ for negativa e significante, e a estatística de segunda ordem $(\mathrm{m} 2)$ for não significante. Para verificar, aplica-se o teste de autocorrelação com base em Arellano e Bond (1991), cuja hipótese nula é ausência de autocorrelação; ii) não correlação das primeiras diferenças defasadas dos regressores endógenos com os erros e os efeitos específicos. Para isso, utiliza-se o teste de Fisher desenvolvido por Maddala e Wu (1999), cuja hipótese nula implica na existência de raiz unitária (GABRIEL, 2011); iii) não correlação dos regressores estritamente exógenos com os erros de qualquer período de tempo. Pode-se avaliar esta hipótese com base no teste de restrições de sobre-identificação de Hansen/Sargan (J), cuja hipótese nula é dada pela validade conjunta dos instrumentos utilizados; iv) Para avaliar a

\footnotetext{
${ }^{47}$ A partir de uma análise de 42 artigos que usaram o método IV em pesquisas contábeis, Larcker e Rusticus (2010) fizeram uma análise rigorosa do método aplicado pelos pesquisadores. Os autores concluíram que as variáveis instrumentais foram selecionadas arbitrariamente, além de carecer de uma discussão teórica. Além disso, os autores afirmaram que, quando o instrumento é fracamente correlacionado com o regressor, o método pode gerar estimativas altamente viesadas, resultando em inferências estatísticas erradas.
} 
validade das suposições adicionais do GMM Sistêmico, foi utilizado o teste de diferença da estatística de Hansen/Sargan. O teste consiste na diferença entre as estatísticas $\mathbf{J}$ de Hansen/Sargan obtidas com o GMM Sistêmico (J1) e com o estimador de diferenças (J2), aplicado ao mesmo modelo. A hipótese nula do teste é de validade das condições adicionais adotadas pelo GMM sistêmico.

\subsubsection{Gerenciamento de Resultados}

A aplicação do GMM Sistêmico no modelo KS resultou nas seguintes estimativas.

Tabela 39 - Estimativas geradas para o modelo KS: estimador GMM Sistêmico

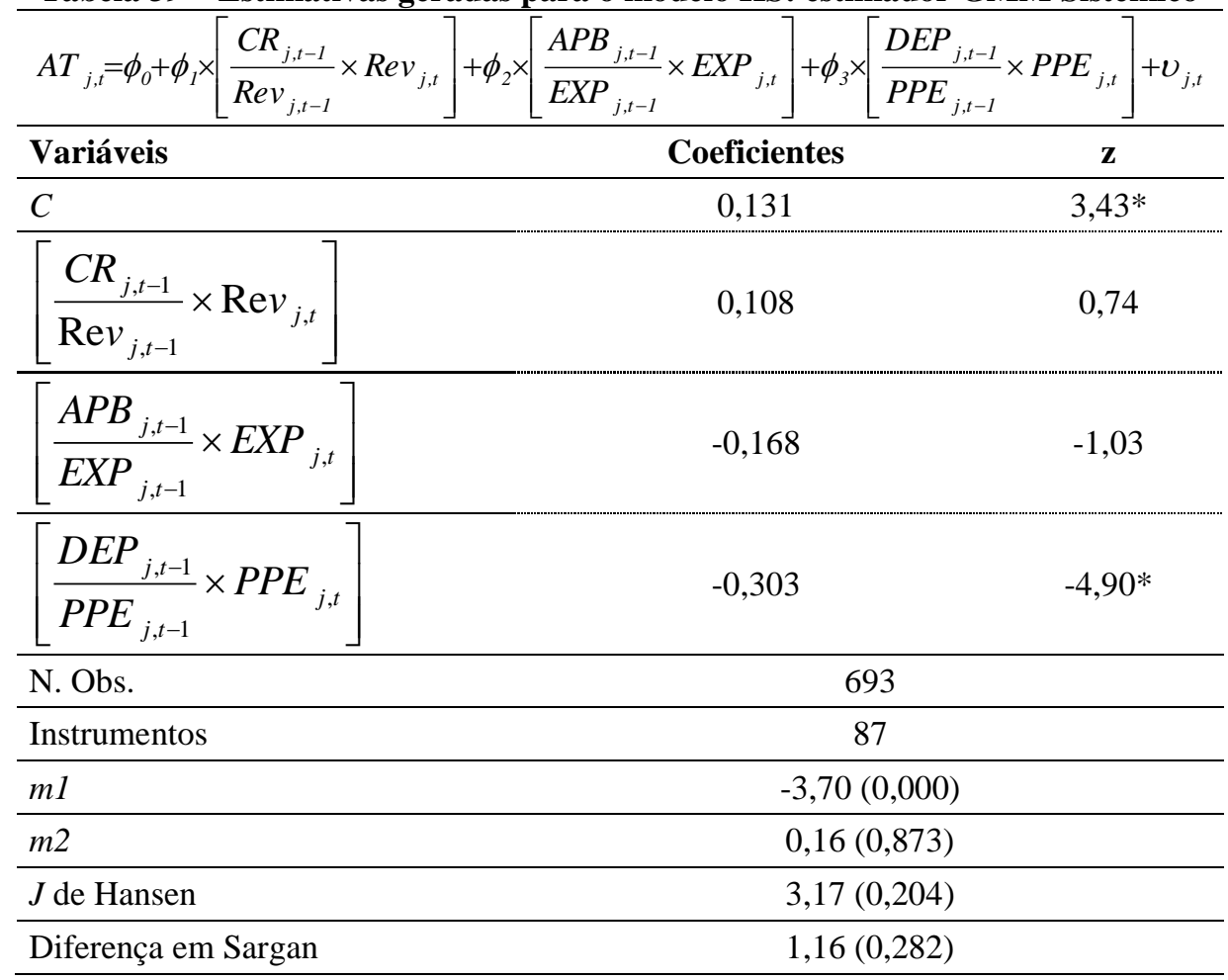

Nota: $A T$ são os accruals totais estimados a partir de equação $18 ; C R$ é o contas a receber da empresa $j ; R e v$ é a receita de vendas da empresa $j ; A P B$ é o capital de giro líquido sem considerar contas a receber da empresa $j$; EXP é a despesa operacional antes da depreciação e amortização da empresa $j$; $D E P$ é a despesa de depreciação e amortização; Asset é o ativo total da empresa $j$; e PPE é o ativo imobilizado da empresa $j$. Coeficientes *, ** e *** são significantes estatisticamente a nível de $0,01,0,05$ e 0,10 , respectivamente.

Ressalta-se que as premissas do modelo GMM foram atendidas conferindo validade às estimativas. A tabela 47, no apêndice, contém os resultados para o teste de raiz unitária.

Após estimação do modelo KS, os resíduos foram utilizados como proxy para gerenciamento de resultados, permitindo avaliar o efeito da adoção completa dado pela dummy IFRS na variável de GR, conforme tabela a seguir. 
Tabela 40 - Estimativas geradas para a equação 31, baseada em Tendeloo e Vanstraelen (2005): estimador GMM Sistêmico

\begin{tabular}{|c|c|c|}
\hline \multicolumn{3}{|c|}{$\left|A D_{K S, G M M_{i t}}\right|=\beta_{0}+\beta_{1}$ IFRS $_{i t}+\beta_{2} A D R_{i t}+\beta_{3} B C G I_{i t}+\beta_{4} C F_{i t}+\beta_{5} D E B T_{i t}+\varepsilon_{i t}$} \\
\hline Variáveis & Coeficientes & $\mathbf{Z}$ \\
\hline IFRS & $-0,006$ & $-2,00 * *$ \\
\hline$B C G I$ & 0,043 & $3,07 *$ \\
\hline$A D R$ & $-0,007$ & $-0,88$ \\
\hline$C F$ & $-0,001$ & $-1,10$ \\
\hline$D E B T$ & 0,001 & $8,98 *$ \\
\hline N. Obs. & \multicolumn{2}{|c|}{310} \\
\hline Instrumentos & \multicolumn{2}{|c|}{31} \\
\hline$m 1$ & \multicolumn{2}{|c|}{$-3,08(0,002)$} \\
\hline \multicolumn{2}{|l|}{$m 2$} & $-1,48(0,139)$ \\
\hline \multicolumn{2}{|l|}{$J$ de Hansen } & $34,29(0,454)$ \\
\hline \multicolumn{2}{|c|}{ Diferença em Sargan } & $0,70(0,404)$ \\
\hline \multicolumn{3}{|c|}{$\begin{array}{l}\text { Nota: }\left|A D_{K S, G M}\right| \text { refere-se a proxy de gerenciamento de resultado baseada no modelo KS (equação } 30 \text { ); } C F \text { é o } \\
\text { fluxo de caixa operacional estimado pela diferença entre lucro líquido e accruals total (SLOAN, 1996); SIZE é o } \\
\text { logaritmo natural do ativo total; e } D E B T \text { é o total de dívidas dividido pelo total do patrimônio líquido. } \\
\text { Coeficientes } *, * * \text { e } * * * \text { são significantes estatisticamente a nível de } 0,01,0,05 \text { e } 0,10 \text { respectivamente. }\end{array}$} \\
\hline
\end{tabular}

Tal como esperado o coeficiente estimado para IFRS mostrou-se negativo e significante estatisticamente, conferindo robustez aos resultados apresentados anteriormente.

\subsubsection{Reconhecimento oportuno de perdas segundo Basu (1997)}

O GMM Sistêmico aplicado ao modelo de reconhecimento oportuno de Basu (1997) gerou os seguintes resultados. 
Tabela 41 - Estimativas geradas para o modelo de reconhecimento oportuno de perdas segundo Basu (1997): estimador GMM Sistêmico

\begin{tabular}{|c|c|}
\hline \multicolumn{2}{|c|}{$E A R N_{i t}=\alpha+\beta_{1} D R_{i t}+\beta_{2} \operatorname{Re} t_{i t}+\beta_{3} D R_{i t} * \operatorname{Re} t_{i t}+\varepsilon_{j t}$} \\
\hline Variáveis & Coeficientes / z \\
\hline$D R$ & $0,487 /(4,00)^{*}$ \\
\hline$R E T$ & $1,257 /(15,93)^{*}$ \\
\hline$D R * R E T$ & $1,430 /(4,27)^{*}$ \\
\hline$I F R S$ & $-0,288 /(-2,23)^{* *}$ \\
\hline$I F R S * D R$ & $0,575 /(1,83)^{* * *}$ \\
\hline$I F R S * R E T$ & $-1,585 /(-10,49)^{*}$ \\
\hline IFRS*DR*RET & $1,748 /(2,73)^{*}$ \\
\hline N. Obs. & 544 \\
\hline Instrumentos & 58 \\
\hline$m 1$ & $-3,19(0,001)$ \\
\hline$m 2$ & $-1,08(0,278)$ \\
\hline$J$ de Hansen & $47,53(0,451)$ \\
\hline Diferença em Sargan & $0,04(0,838)$ \\
\hline
\end{tabular}

Coeficientes $*, * *$ e *** são significantes estatisticamente a nível de $0,01,0,05$ e 0,10 respectivamente.

De acordo com o modelo original, pode-se afirmar que o resultado contábil apresenta a característica de conservadorismo, pois a soma dos coeficientes $\beta_{2}$ e $\beta_{3}(1,257+1,430)$ é superior a $\beta_{2}(1,257)$. A adição da variável IFRS no modelo original revela a existência de tempestividade incremental do reconhecimento de perdas, pois o coeficiente de 1,748, dado pela variável IFRS*DR*RET, é positivo e significante estatisticamente a 0,01 , confirmando o maior conservadorismo no período da adoção completa. Assim, este resultado é coerente com os achados apresentados na seção 4.3.1.

\subsubsection{Relevância da Informação Contábil}

As estimativas para o modelo de relevância podem ser observadas a seguir. 
Tabela 42 - Estimativas geradas para o modelo de relevância: estimador GMM Sistêmico

\begin{tabular}{lc}
\hline \multicolumn{1}{c}{$\frac{P_{i t}}{P_{i t-1}}=\alpha_{0 t}+\beta_{1 t} \frac{B V_{i t}}{P_{i t-1}}+\beta_{2 t} \frac{E A R N_{i t}}{P_{i t-1}}+\varepsilon_{i t}$} \\
\hline Variáveis & Coeficientes / z \\
\hline $\boldsymbol{E A R N}$ & $\mathbf{0 , 2 7 8 / ( 4 , 5 1 ) ^ { * }}$ \\
\hline$B V$ & $0,364 /(2,12)^{* *}$ \\
\hline $\boldsymbol{E A R N} *$ IFRS & $\mathbf{1 , 1 3 5 / ( \mathbf { 2 , 7 0 } ) ^ { * }}$ \\
\hline$B V$ *IFRS & $-0,176 /(-2,72)^{*}$ \\
\hline N. Obs. & 553 \\
\hline Instrumentos & 32 \\
\hline$m$ I & $-4,65(0,000)$ \\
\hline$m 2$ & $-0,75(0,452)$ \\
\hline$J$ de Hansen & $49,15(0,347)$ \\
\hline Diferença em Sargan & $0,18(0,667)$
\end{tabular}

Nota: $P_{i t}$ é o preço da ação três meses após o encerramento do ano fiscal em $t$, deflacionado pelo preço em $t-1$ para a empresa $i ; B V_{i t}$ é o patrimônio líquido por ação da empresa $i$ para o período $t$, deflacionado pelo preço em $t-1 ; E A R N_{i t}$ é o resultado líquido por ação da empresa $i$ para o período $t$, deflacionado pelo preço em $t$ - 1 .

Coeficientes *,** e *** são significantes estatisticamente a nível de $0,01,0,05$ e 0,10 respectivamente.

A significância estatística para a variável $E A R N$ indica que a informação contábil é relevante no contexto do mercado de capitais brasileiro. A estimativa para a interação entre a dummy IFRS e EARN apresenta-se significante estatisticamente a 0,01, além de exibir um coeficiente maior em relação à variável $\operatorname{EARN}(1,135>0,278)$. Consequentemente, os achados observados na seção 4.4 são confirmados pelo método GMM Sistêmico.

\subsubsection{Tempestividade da Informação Contábil}

Por sua vez, a aplicação do GMM Sistêmico para o modelo de tempestividade gerou os seguintes resultados: 
Tabela 43 - Estimativas geradas para o modelo de tempestividade: estimador GMM Sistêmico

\begin{tabular}{|c|c|}
\hline \multicolumn{2}{|c|}{$\operatorname{Re} t_{i t}=\alpha+\beta_{1} E A R N_{i t}+\beta_{2}\left(E A R N_{i t}-E A R N_{i t-1}\right)+\varepsilon_{i t}$} \\
\hline Variáveis & Coeficientes / z \\
\hline $\mathrm{C}$ & $0,577 /(8,68)^{*}$ \\
\hline$E A R N_{i t}$ & $0,203 /(1,32)$ \\
\hline $\begin{array}{l}E A R N_{i t}-E A R N_{i t-1} \\
\end{array}$ & $0,302 /(1,90)^{* *}$ \\
\hline$E A R N_{i t} * I F R S$ & $-2,114 /(-2,74)^{*}$ \\
\hline$\left(E A R N_{i t}-E A R N_{i t-1}\right) * I F R S$ & $1,595 /(1,74) * * *$ \\
\hline N. Obs. & 542 \\
\hline Instrumentos & 33 \\
\hline$m 1$ & $-3,76(0,000)$ \\
\hline$m 2$ & $1,10(0,269)$ \\
\hline$J$ de Hansen & $40,20(0,151)$ \\
\hline Diferença em Sargan & $0,54(0,461)$ \\
\hline
\end{tabular}

Nota: Coeficientes *, ** e *** são significantes estatisticamente a nível de 0,01, 0,05 e 0,10 respectivamente; $\operatorname{Ret}_{i t}$ é o retorno da ação para a empresa $i$ no ano $t ; E A R N_{i t}$ é o lucro por ação da empresa $i$ no ano $t ; E A R N_{i t-1}$ é o lucro por ação da empresa $i$ no ano $t$ - 1 . As variáveis de lucro são deflacionadas pelo preço em $t$ - 1 , com o propósito de reduzir problemas de escala.

Os achados da tabela 43 revelam que a informação é tempestiva ou oportuna no mercado de capitais brasileiro, em especial no período de adoção completa das IFRS, que apresentou maior coeficiente $(1,595>0,302)$. Logo, o GMM Sistêmico confirma as evidências empíricas apresentadas na seção 4.5 .

\subsubsection{Custo de Capital Próprio e Qualidade da Informação Contábil}

Por último, o modelo de custo de capital e qualidade da informação contábil é estimado pelo GMM Sistêmico. Neste caso, adota-se como proxy da qualidade da informação contábil os resíduos do modelo KS. 
Tabela 44 - Estimativas geradas para avaliar a relação entre custo de capital próprio e gerenciamento de resultado conforme equação 59: estimador GMM Sistêmico

$$
\begin{aligned}
& r_{P E G_{i t}}=\alpha_{0}+\alpha_{1}\left|A D_{K S, G M M_{i t}}\right|+\alpha_{2}\left|A D_{K S, G M M_{i t}}\right| * I F R S_{i t}+\alpha_{3} S I Z E_{i t}+\alpha_{4} D E B T_{i t}+\alpha_{5} C F_{i t}+\alpha_{6} A D R_{i t}+ \\
& +\alpha_{7} B C G I_{i t}+\alpha_{8} V O L_{i t}+\varepsilon_{i t}
\end{aligned}
$$

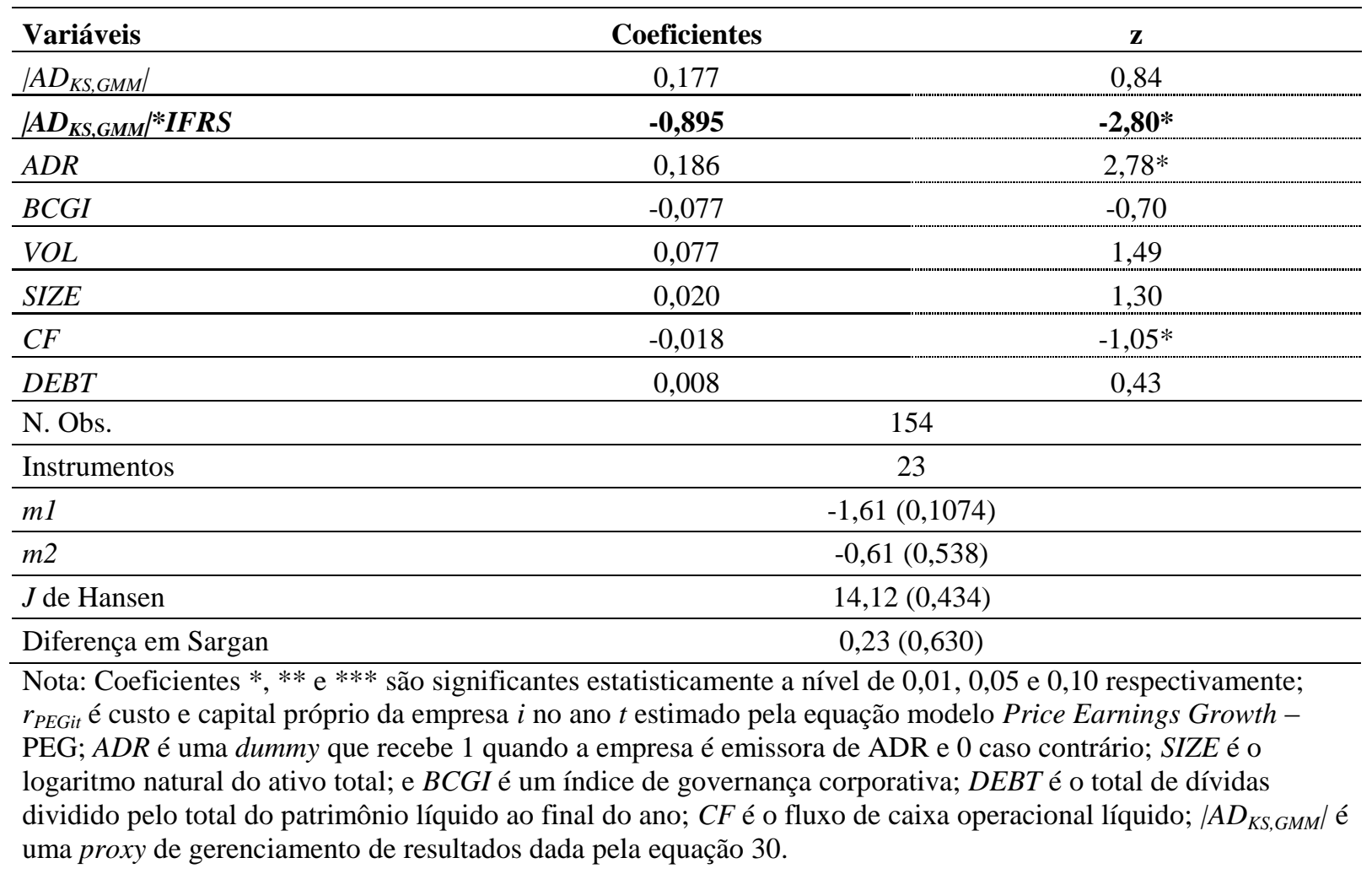

Nota-se que a variável $\left|\mathrm{AD}_{\mathrm{KS}, \mathrm{GMM}}\right|$ não foi significante estatisticamente, muito provavelmente em função da reduzida quantidade de observações da regressão. No entanto, a variável de interesse dada pela interação entre $\left|A D_{K S, G M M}\right|$ e IFRS revela uma redução no custo de capital próprio em função de um aumento na qualidade da informação contábil. Este resultado é coerente com o cenário de aumento da qualidade da informação contábil. Portanto, os achados da seção 4.7 são admitidos, conferindo maior robustez aos testes.

\subsection{Síntese dos achados}

Os resultados observados para os modelos e suas implicações para as hipóteses de pesquisa podem ser resumidos na tabela 45 . 
Tabela 45 - Síntese dos resultados para as hipóteses de pesquisa

\begin{tabular}{|c|c|c|c|}
\hline $\begin{array}{l}\text { Dimensão da qualidade } \\
\text { da informação contábil }\end{array}$ & Modelo & Hipótese de pesquisa & Resultado \\
\hline $\begin{array}{c}\text { Gerenciamento de } \\
\text { resultados }\end{array}$ & $\begin{array}{l}\text { Barth et al (2006) e Lang, } \\
\text { Raedy e Wilson (2006) }\end{array}$ & $\begin{array}{l}\text { Redução do GR após } \\
\text { adoção completa }\end{array}$ & Não conclusivo \\
\hline $\begin{array}{l}\text { Gerenciamento de } \\
\text { resultados }\end{array}$ & $\begin{array}{c}\text { Teoh, Welch e Wong } \\
\text { (1998) ou TEOH }\end{array}$ & $\begin{array}{c}\text { Redução do GR após } \\
\text { adoção completa }\end{array}$ & Não conclusivo \\
\hline $\begin{array}{l}\text { Gerenciamento de } \\
\text { resultados }\end{array}$ & $\begin{array}{c}\text { Dechow, Sloan e } \\
\text { Sweeney (1995) ou Jones } \\
\text { Modificado (JM) }\end{array}$ & $\begin{array}{l}\text { Redução do GR após } \\
\text { adoção completa }\end{array}$ & Não conclusivo \\
\hline $\begin{array}{l}\text { Gerenciamento de } \\
\text { resultados }\end{array}$ & $\begin{array}{c}\text { Kang e Sivaramakrishnan } \\
\text { (1995) ou KS }\end{array}$ & $\begin{array}{l}\text { Redução do GR após } \\
\text { adoção completa }\end{array}$ & Não conclusivo \\
\hline $\begin{array}{l}\text { Gerenciamento de } \\
\text { resultados }\end{array}$ & $\begin{array}{c}\text { Baseado em Tendeloo e } \\
\text { Vanstraelen (2005) }\end{array}$ & $\begin{array}{l}\text { Redução do GR após } \\
\text { adoção completa }\end{array}$ & Aceita \\
\hline $\begin{array}{l}\text { Conservadorismo } \\
\text { Condicional }\end{array}$ & $\begin{array}{c}\text { Reconhecimento oportuno } \\
\text { de perdas segundo Basu } \\
(1997)\end{array}$ & $\begin{array}{c}\text { Aumento do } \\
\text { conservadorismo após } \\
\text { adoção completa }\end{array}$ & Aceita \\
\hline $\begin{array}{l}\text { Conservadorismo } \\
\text { Condicional }\end{array}$ & $\begin{array}{c}\text { Componentes transitórios } \\
\text { do lucro de acordo com } \\
\text { Basu (1997) }\end{array}$ & $\begin{array}{c}\text { Aumento do } \\
\text { conservadorismo após } \\
\text { adoção completa }\end{array}$ & Aceita \\
\hline $\begin{array}{l}\text { Conservadorismo } \\
\text { Condicional }\end{array}$ & Ball e Shivakumar (2005) & $\begin{array}{c}\text { Aumento do } \\
\text { conservadorismo após } \\
\text { adoção completa } \\
\end{array}$ & $\begin{array}{l}\text { Aceita ao controlar por } \\
\text { ADR e BCGI }\end{array}$ \\
\hline Relevância & Easton (1999) & $\begin{array}{l}\text { Aumento da relevância } \\
\text { da informação contábil } \\
\text { após adoção completa }\end{array}$ & Aceita \\
\hline Tempestividade & Easton (1999) & $\begin{array}{c}\text { Aumento da } \\
\text { tempestividade da } \\
\text { informação contábil } \\
\text { após adoção completa }\end{array}$ & Aceita \\
\hline $\begin{array}{l}\text { Tempestividade - curto } \\
\text { prazo }\end{array}$ & Horton e Serafeim (2009) & $\begin{array}{c}\text { Aumento da } \\
\text { tempestividade da } \\
\text { informação contábil } \\
\text { após adoção completa }\end{array}$ & Aceita \\
\hline Relevância - curto prazo & Horton e Serafeim (2009) & $\begin{array}{l}\text { Aumento da relevância } \\
\text { da informação contábil } \\
\text { após adoção completa }\end{array}$ & Não aceita \\
\hline Custo de Capital & Modelo & Hipótese & Resultado \\
\hline $\begin{array}{l}\text { Custo de capital próprio } \\
\text { baseado em Easton (2004) }\end{array}$ & Baseado em Li (2010) & $\begin{array}{l}\text { Redução no custo de } \\
\text { capital própria após } \\
\text { adoção completa }\end{array}$ & Aceita \\
\hline $\begin{array}{l}\text { Custo de capital próprio } \\
\text { baseado em Easton (2004) }\end{array}$ & $\begin{array}{l}\text { Baseado em Francis et al } \\
\qquad(2005)\end{array}$ & $\begin{array}{l}\text { Redução no custo de } \\
\text { capital própria após } \\
\text { adoção completa }\end{array}$ & Aceita \\
\hline
\end{tabular}

Os resultados da tabela 45 são favoráveis à aceitação das hipóteses de pesquisa referente ao aumento da qualidade da informação contábil e redução do custo de capital próprio. 


\section{CONSIDERAÇÕES FINAIS}

Esta tese se desenvolve em torno do processo de convergências às IFRS, com destaque para o período de adoção completa (2010 e 2011). Em resumo, esperou-se observar um aumento na qualidade da informação contábil, por meio da redução no nível de gerenciamento de resultados, do aumento no conservadorismo condicional, do aumento na relevância e na tempestividade da informação contábil. Consequentemente, era esperada uma redução no custo de capital próprio das empresas que possuem ações no mercado de capitais. Algumas pesquisas constataram tais resultados para os países da União Europeia que adotaram obrigatoriamente as IFRS a partir de $2005^{48}$, contudo o resultado foi influenciado fortemente por aspectos institucionais e legais dos países membros. Os países de sistema legal code law apresentaram resultados não confirmatórios. Este efeito é consistente com investidores preocupados com a implementação de IFRS em países com baixo poder de enforcement. Aliada a esta questão, há ainda a peculiaridade do processo de convergência no Brasil que foi realizado em duas etapas. Portanto, o cenário brasileiro apresenta elementos específicos que devem ser considerados na investigação do impacto das normas internacionais de contabilidade.

\subsection{Um Resumo das Evidências Empíricas}

O objetivo da tese se resumiu na investigação da adoção completa das IFRS em duas vertentes: i) análise da mudança de GAAP (BRGAAP para IFRS) na qualidade da informação contábil de acordo com o portfolio approach (BARTH et al, 2006), uma abordagem que observa algumas dimensões da qualidade da informação contábil; e ii) análise do custo de capital próprio no período da adoção completa da IFRS. De maneira geral, espera-se um aumento na qualidade da informação contábil full IFRS das empresas brasileiras em 2010 e 2011, acompanhado de uma redução no custo de capital próprio, conforme pesquisas na literatura nacional e internacional já constataram.

Neste sentido, a qualidade da informação contábil foi investigada a partir das seguintes dimensões: gerenciamento de resultados (GR), conservadorismo condicional, relevância e

\footnotetext{
${ }^{48}$ O quadro 1 apresenta um resumo de vários trabalhos nacionais e internacionais que investigaram as consequências econômicas da adoção das IFRS.
} 
tempestividade. Os modelos de gerenciamento aplicados podem identificar o exercício da discricionariedade voltada para o atendimento de interesses específicos, os quais implicam em informação não confiável ou enganosa. Os modelos de GR aplicados nesta tese são baseados em: i) Barth et al (2006) e Lang, Raedy e Wilson (2006); ii) Teoh, Welch e Wong (1998) ou TEOH; iii) Dechow, Sloan e Sweeney (1995) ou Jones Modificado (JM); e iv) Kang e Sivaramakrishnan (1995) ou KS. Os resultados do modelo baseado em Barth et al (2006) e Lang, Raedy e Wilson (2006) não são conclusivos, visto que a desvalorização da taxa de câmbio em 1999, 2002 e a Crise Financeira de 2008 dificultam a análise dos elementos discricionários. Por outro lado, os accruals discricionários (AD) para os modelos TEOH, JM e KS são convergentes (vide gráfico 5), apresentando um aumento em 2010, seguindo de uma redução em 2011. O maior nível de AD em 2010 não reflete necessariamente a hipótese de manipulação prevista por Dechow (1994), visto que há casos de tratamentos contábeis heterogêneos para eventos similares, caracterizando uma dificuldade prevista na transição de GAAP.

Considerando que o modelo KS apresenta resultados satisfatórios (MARTINEZ, 2001), seus accruals discricionários foram regredidos no modelo adaptado de Tendeloo e Vanstraelen (2005), com o propósito de investigar se os $\left|A D_{K S}\right|$ diminuíram no período da adoção completa das IFRS. Os resultados revelam que os accruals discricionários, proxy para GR, diminuíram no período da adoção completa, consistente com a hipótese de pesquisa que prevê uma redução no gerenciamento de resultados.

O conservadorismo condicional é a segunda dimensão da qualidade da informação contábil investigada, sendo dividida em três modelos: i) reconhecimento oportuno de perdas segundo Basu (1997); ii) modelo de componentes transitórios do lucro de acordo com Basu (1997); e iii) modelo de Ball e Shivakumar (2005). Os 3 modelos indicam um aumento no conservadorismo condicional após adoção completa das IFRS, um resultado que permite aceitar a hipótese de pesquisa de conservadorismo condicional. No entanto, os resultados do modelo de Ball e Shivakumar (2005) são favoráveis à aceitação da hipótese de conservadorismo apenas ao controlar por ADR e BCGI.

A relevância (value-relevance) é a terceira dimensão da informação contábil avaliada. Os resultados revelam um aumento na relevância da informação contábil após adoção completa 
das IFRS, os quais permitem aceitar a hipótese de pesquisa de relevância. Este resultado também é válido ao controlar por práticas de governança corporativa (BCGI e ADR).

A última dimensão analisada corresponde à tempestividade da informação contábil, que reflete a percepção dos investidores diante da divulgação das demonstrações contábeis. $\mathrm{O}$ modelo estudado revela um aumento na tempestividade da informação full IFRS, admitindo a aceitação da hipótese de tempestividade.

O estudo de evento aplicado para os 11 dias ao redor da divulgação das demonstrações contábeis full IFRS fornece evidências empíricas para o curto prazo. A análise gráfica, o teste dos sinais e a regressão linear múltipla revelam que a informação contábil é útil para o mercado de capitais, pois há indícios de que o mercado reagiu quando da divulgação dos relatórios contábeis em IFRS, ou seja, confirma-se a hipótese de tempestividade. Neste sentido, pode-se concluir que a informação contábil em IFRS foi refletida no preço das ações, dada a alteração de retornos anormais após a data de divulgação. Destaca-se o retorno anormal das empresas que emitem ADRs, indicando uma reação exagerada na data de divulgação das IFRS, devido aos incentivos para apresentar maior conteúdo informacional. Além disso, as empresas que adotaram as IFRS antecipadamente revelaram um efeito negativo no retorno anormal, tanto no teste de sinais ao considerar o retorno anormal acumulado, quanto na regressão linear múltipla (tabela 35). Embora seja esperado um efeito positivo e maior para os precursores na adoção das IFRS (DASKE et al 2008), houve uma proximidade entre o GAAP adotado pela empresa e a adoção completa das IFRS (SODERSTROM; SUN, 2007), possivelmente implicando em antecipação dos efeitos da mudança de GAAP. A maioria das empresas que compõem o subgrupo de empresas voluntárias (tabela 46) divulgou suas primeiras demonstrações contábeis full IFRS em 2009 e 2010, sendo que as demonstrações de 2008 e 2009 já seguiam metade das normas internacionais de contabilidade - o período da adoção parcial das IFRS corresponde a 2008 e 2009. Portanto, as consequências econômicas advindas da adoção pela primeira vez podem ter sido antecipadas, culminando em retorno anormal negativo. Esta reação negativa pode ser explicada pela heterogeneidade na aplicação das IFRS, permitindo um aumento no poder discricionário dos gestores (ARMSTRONG et al 2010), coerente com o maior nível de accruals discricionários observado para o primeiro ano de adoção completa. No entanto, o segundo ano demonstra uma reversão na proxy para gerenciamento de resultado. 
No que diz respeito à relevância da informação contábil, os achados não permitem aceitar a hipótese de relevância para o curto prazo. No entanto, os resultados foram obtidos a partir de uma regressão em corte transversal, que corresponde ao estudo da associação entre preço de ação e números contábeis num dado instante de tempo. Por outro lado, a análise na perspectiva de longo prazo (seção 4.4) utiliza-se de dados em painel, um método que combina corte transversal e séries temporais, reduzindo problemas de multicolinearidade, aumentando o número de observações e os graus de liberdade. Portanto, os resultados favoráveis à aceitação da hipótese de relevância da informação contábil na adoção completa das IFRS (seção 4.4) foram gerados a partir de um método mais robusto, aumentando a validade dos achados.

Portanto, as evidências empíricas para as dimensões da qualidade da informação contábil gerenciamento de resultados, conservadorismo, relevância e tempestividade - indicam a aceitação da hipótese de aumento na qualidade da informação contábil após adoção completa das IFRS. Neste sentido, o conjunto desses resultados sugere um modelo contábil que efetivamente fornece informações para o mercado de capitais, corroborando os achados de trabalhos nacionais (LIMA, 2010) e internacionais (LIU; LIU, 2007; BARTH; LANDSMAN; LANG, 2008; HORTON; SERAFEIM, 2009), os quais constataram que a adoção das IFRS aumenta a qualidade da informação contábil. Um ponto que merece destaque é a possibilidade de encontrar resultados diferentes ao controlar por características institucionais dos países (BALL, 2006), implicando em efeito menor para países de ambiente legal com baixo poder de enforcement. No entanto, esse aspecto não se aplica ao caso brasileiro que, apesar de ser classificado como um país de origem code law, oferecendo baixa proteção aos investidores (LA PORTA; LOPEZ-DE-SILANES; SHLEIFER, 1998), os benefícios da adoção completa das IFRS são observados.

A partir de estudos que consideram o ambiente institucional brasileiro fraco (LA PORTA; LOPEZ-DE-SILANES; SHLEIFER, 1998; ANDERSON, 1999; CHONG; LOPEZ-DESILANES, 2007) decidiu-se avaliar o papel das práticas de governança corporativa na transição de GAAP. Para isso, as variáveis BCGI e ADR foram adicionadas nos modelos para avaliar o efeito incremental na qualidade da informação contábil full IFRS. Os achados revelam que a qualidade da informação contábil é aumentada na maioria dos modelos da portfolio approach, coerente com o estudo de Lopes e Walker (2008), que constatou uma 
influência das práticas de governança corporativa na qualidade dos números contábeis das empresas brasileiras.

No que diz respeito ao custo de capital próprio, os modelos das seções 4.1 e 4.7 sugerem uma redução no custo de capital próprio após adoção completa da IFRS, permitindo a aceitação da hipótese de pesquisa de custo de capital próprio. Considerando que as IFRS proporcionam maior nível de divulgação das empresas, este resultado está coerente com os trabalhos que encontraram uma relação negativa entre custo de capital próprio e disclosure, tais como Botosan (1997) e Lopes e Alencar (2010). Os achados de Lopes e Alencar (2010) devem ser destacados, pois sugerem que as normas destinadas a aumentar o nível de divulgação, em países de baixa divulgação, podem levar a reduções no custo de capital próprio. Há diversos exemplos a respeito do maior nível de divulgação das IFRS devido ao registro de transações anteriormente não contabilizadas ou contabilizadas não adequadamente, tais como: i) pagamento baseado em ações; ii) teste de impairment; iii) arrendamento mercantil financeiro; iv) registro da depreciação de acordo com o padrão de consumo dos benefícios do ativo; v) ativos não correntes mantidos para venda e operações descontinuadas; vi) registro de propriedade para investimento; vii) dividendo adicional proposto no patrimônio líquido; viii) reconhecimento dos contratos de concessão em ativo financeiro ou intangível; ix) a conta de ajustes de avaliação patrimonial destinada ao registro de variação de ativos e passivos avaliados a valor justo etc.

Neste contexto, as demonstrações contábeis em IFRS podem revelar maior conteúdo informacional, pois ao registrar eventos econômicos anteriormente não contabilizados, os números contábeis divulgados podem aproximar-se da verdadeira posição econômicofinanceira das empresas. Tal informação torna-se relevante para os investidores interessados em avaliar as empresas.

Além disso, a variável BCGI (tabelas 7 e 38) apresenta sinal negativo, indicando que as práticas de governança corporativa contribuem para reduzir o custo de capital próprio das empresas, coerente com Lopes (2008). Portanto, as empresas que buscam financiamento em função de oportunidades de crescimento devem se comprometer com práticas superiores de governança corporativa, com o objetivo de reduzir os custos de agência e, consequentemente, o custo de capital próprio. 
Enfim, os resultados obtidos para qualidade da informação contábil e custo de capital próprio nesta tese confirmam as declarações dos defensores das IFRS a respeito das consequências econômicas decorrentes da adoção de tais normas, e, também, corroboram diversas evidências empíricas (quadro 1). Ênfase deve se dada para o atual presidente do IASB, Hans Hoogervorst, que defende um aumento na transparência das demonstrações contábeis (IFRS, 2011), e para o ex-presidente David Tweedie, que justifica a redução do custo de capital.

\subsection{Implicações para os Interessados}

Este estudo confirma a existência de aumento no conteúdo informacional e redução no custo de capital próprio após adoção completa das IFRS. Estes achados podem ser úteis para vários interessados, tais como:

- Analistas - este grupo de usuários exerce papel importante no mercado de capitais, visto que se empenha para fornecer informação sobre o desempenho econômicofinanceiro vindouro das empresas, contribuindo para reduzir a assimetria informacional entre os agentes. A mudança de GAAP experimentada pelas empresas brasileiras revelou maior conteúdo informacional das demonstrações contábeis full IFRS. Neste sentido, as informações contábeis podem ser mais úteis no contexto de elaboração de previsões, pois novas práticas contábeis passaram a ser adotadas pelas empresas, contribuindo para aumentar o nível de divulgação dos relatórios contábeis. Com mais informações sobre a posição financeira das empresas, os analistas podem avaliar mais adequadamente os seus riscos e apresentar estimativas mais precisas. Consequentemente, a qualidade das previsões contábeis pode influenciar outros usuários da informação, como investidores ou acionistas, que, por sua vez, tomam decisões de compra, venda ou manutenção de investimentos em ações. Logo, é possível visualizar uma ligação entre qualidade da informação contábil e eficiência de investimentos, sendo que os analistas exercem papel-chave neste processo.

- Acionistas - os proprietários de capital também precisam de informação útil para fins de avaliação do desempenho econômico-financeiro das empresas. Estes estão interessados em avaliar a capacidade de distribuição de dividendos, além do potencial de valorização das ações das companhias. No entanto, as suas estratégias de investimento podem se diferenciar em função do período que estão dispostos a manter 
seus recursos aplicados. Os acionistas que buscam rentabilidade no longo prazo podem recorrer à análise fundamentalista para avaliar a saúde financeira das empresas, projetar seus números contábeis e determinar o preço justo para suas ações. Os achados desta tese mostram maior relevância e tempestividade para as demonstrações contábeis em IFRS, contribuindo para os modelos de decisão pautados na análise fundamentalista, ou algum outro método que dependa de informação de qualidade para projetar os números das companhias. Em resumo, o maior conteúdo informacional dado pelas demonstrações contábeis de acordo com as IFRS pode proporcionar alguns benefícios para os acionistas de acordo com a literatura. Alguns exemplos são: aumento da liquidez das ações, oportunidades de investimento proporcionando retornos superiores, uniformização de regras para atender questões contratuais, ou seja, redução dos custos de transação e da assimetria informacional, contribuindo para uma alocação de recursos no mercado de maneira mais eficiente. Adicionalmente, esta tese fornece evidências empíricas favoráveis à adoção das IFRS em um país de origem legal code law, sendo que há estudos internacionais que observam benefícios oriundos da adoção de IFRS apenas em países de origem common law, refletindo diferenças institucionais. Este aspecto representa um incentivo para investimentos estrangeiros no Brasil, assumindo que as demonstrações contábeis representam um dos principais elementos nas decisões de potenciais acionistas.

- Reguladores - os resultados desta tese corroboram declarações de representantes do IASB acerca das consequências econômicas advindas da adoção das IFRS, que se resumem, basicamente, em maior transparência das demonstrações contábeis e redução no custo de capital das companhias. Neste sentido, este trabalho pode fortalecer a posição do IASB nas atuais discussões sobre o processo de convergência de outros países, como os Estados Unidos. Sabe-se que o IASB e a SEC ainda não encontraram um consenso no que diz respeito à adoção das normas internacionais, sendo que a convergência da maior economia do planeta poderia reforçar o processo de convergência de outros países. Portanto, os resultados desta tese revelam incentivos para os reguladores continuarem apoiando a adoção das IFRS. Todavia, estudos adicionais poderiam investigar os efeitos proporcionados por uma norma específica, com o propósito de trazer evidências sobre a sua utilidade no âmbito do mercado de capitais. Estas pesquisas poderiam orientar os reguladores quanto a eventuais ajustes ou modificações nas normas contábeis. 
- Executivos - este grupo de usuários pode perceber o conjunto de normas internacionais de contabilidade como a possibilidade de sinalizar uma posição econômico-financeira mais fidedigna, visto que novas práticas contábeis foram introduzidas após adoção das IFRS, como a norma de Pagamento Baseado em Ações. Neste sentido, considerando que as IFRS representam um conjunto de normas de alta qualidade, os executivos podem elaborar e divulgar demonstrações contábeis mais transparentes, reduzindo o risco de seleção adversa no mercado de ações. Esta tese revela maior conteúdo informacional após IFRS, coerente com ações voltadas para aumento da transparência. No entanto, sabe-se que os incentivos para gerenciamento de resultados podem ter permanecido durante o processo de convergência, invalidando os benefícios que poderiam ser proporcionados pelas normas internacionais. Ao contrário disso, esta tese revela uma redução no nível de gerenciamento de resultados, evidenciando um aumento na qualidade da informação contábil. Uma explicação para isto deve-se à redução da habilidade da administração em gerenciar diante da emissão de uma nova norma (WATTS; ZIMMERMAN, 1986). Além disso, a possibilidade de comparar as demonstrações contábeis das empresas brasileiras com outros países que adotam IFRS pode causar maior preocupação por parte da administração, visto que o número de pessoas acompanhando os relatórios contábeis pode aumentar. Logo, pode haver maior fiscalização a nível internacional por eventos registrados nos balanços das companhias, implicando em menor divulgação agressiva.

Entre os interessados, há quem argumente que, um aumento na qualidade das demonstrações contábeis implica em maior divulgação e, consequentemente, maior custo de capital próprio. Este raciocínio baseia-se na hipótese de que os investidores terão mais informação a respeito dos negócios da empresa, conseguindo capturar ações discricionárias dos gestores voltadas para manipular as demonstrações contábeis. Neste cenário, é plausível conjecturar um aumento no custo de capital, dado que o investidor fez uma leitura adequada do risco de seleção adversa. No curto prazo esta linha de raciocínio é totalmente coerente. Não obstante, ao analisar uma perspectiva de longo prazo, a conclusão pode ser diferente. Ao aumentar a qualidade de divulgação das demonstrações contábeis em $t$, os investidores terão acesso às boas e más notícias da empresa, considerando que a política de divulgação remete à publicação imediata por meio de vários canais de comunicação (site, press release, 
jornais de grande circulação, reunião com diretor de relações com investidores etc.). Assim, aquelas notícias desfavoráveis terão impacto no preço da ação em $t$, e, em função da ampla divulgação, os investidores poderão ter maior confiança nos números contábeis da empresa, diminuindo qualquer efeito surpresa. Por outro lado, outras empresas podem postergar a divulgação de uma má notícia para $t+1, t+2$ etc. Quando a má notícia tornar-se pública, o mercado pode exigir um prêmio maior dado que esta empresa não divulgou no momento $t$, implicando em efeito maior no custo de capital próprio. Ao comparar os dois grupos de empresas, de divulgação imediata e de postergação, as práticas da gestão podem conduzir a níveis diferentes de divulgação ou qualidade das demonstrações contábeis, resultando em diferenças no custo de capital próprio. O grupo de empresas que posterga informação ou não divulga de acordo com as normas contábeis, pode ser penalizada mediante a exigência de um prêmio maior pelos investidores. Portanto, pode-se concluir que a qualidade da divulgação pode reduzir o custo de capital próprio, coerente com vários trabalhos da literatura.

\subsection{Limitações da Pesquisa}

Uma das principais limitações deste estudo refere-se ao colapso do sistema financeiro global que culminou na crise financeira de 2008. Alguns argumentam que a informação contábil em tempos de crise torna-se menos relevante e confiável, mas não por um problema com a forma de mensuração dos ativos e passivos, mas devido ao elevado risco sistêmico que todos os agentes estão expostos. Além disso, há aspectos institucionais, legais e culturais que devem ser considerados na pesquisa, como a elevada concentração de propriedade no mercado de ações brasileiro, além de outras diferenças em relação aos mercados desenvolvidos.

As evidências empíricas obtidas nesta tese limitam-se às empresas que compõem à amostra. Apesar de usar o portfolio approach para observar qualidade da informação contábil, encontram-se na literatura outros métodos, os quais poderiam gerar resultados diferentes. Portanto, ao analisar os resultados desta tese deve-se considerar que as dimensões da qualidade da informação contábil restringem-se aos modelos do portfolio approach.

Outras limitações que devem ser destacadas são: 
- Modelos econométricos - os modelos usados para observar as características qualitativas da informação contábil possuem limitações que são amplamente discutidas na literatura. Por exemplo, os modelos para avaliação da relevância da informação contábil baseados em preço das ações possuem, entre as variáveis explicativas, o lucro corrente, sendo que grande parte das variações no preço das ações é explicada pelo lucro futuro, ou seja, uma expectativa do mercado para $t+1$, que influencia o preço em $t$. Isto resulta no problema das variáveis não observáveis, implicando em estimadores não consistentes. No entanto, após alguns anos de amadurecimento desta linha de pesquisa, novos métodos de correção ou novas abordagens foram desenvolvidos, visando aumentar a validade dos resultados, tal como a utilização de variáveis instrumentais no modelo KS.

- Período analisado - o período de adoção das normas internacionais de contabilidade considerado nesta tese é relativamente curto, visto que o estudo restringe-se à apenas dois anos, 2010 e 2011. Em função disso, sugere-se, como continuação desta pesquisa, ampliar os anos de adoção das IFRS, para verificar se os benefícios observados se mantêm nos anos vindouros.

- Erros de mensuração - a definição operacional das variáveis pode ser acompanhada de erros, visto que algumas possuem limitações básicas. Assim, as métricas utilizadas podem não capturar adequadamente aquilo que se propõe a mensurar. Além disso, as variáveis de interesse, por exemplo, os resíduos considerados como proxy para gerenciamento de resultados, podem refletir outros incentivos, que não foram tratados no conjunto de variáveis observáveis. Uma alternativa para reduzir problemas associados aos erros de mensuração deve-se à aplicação de abordagens diferentes para investigar qualidade da informação.

- Pressupostos dos modelos - as variáveis omitidas, os erros na mensuração de variáveis e o viés de seleção da amostra implicam em problemas de endogeneidade, resultando em coeficientes estimados enviesados e inconsistentes. No entanto, a aplicação do GMM Sistêmico, um método mais robusto, pode reduzir a incidência destes problemas, visto que seu uso independe da disponibilidade de instrumentos exógenos para os regressores.

- Base de dados - o modelo de estimação de custo de capital próprio é baseado no Price Earnings Growth - PEG, que depende das estimativas de lucro por ação dos analistas de mercado. Porém, o número de empresas acompanhadas por analistas, disponível no 
Data Stream da Thomson, é baixo em relação aos outros mercados, implicando em estimativas limitadas. Além disso, os dados contábeis usados nesta tese estão sujeitos a erros de classificação ou digitação em função de serem dados secundários.

- Custo de capital próprio - o modelo para estimar o custo de capital próprio (PEG) possui algumas premissas, por exemplo, assume-se que o crescimento anormal esperado no resultado fornece uma estimativa imparcial deste crescimento para os próximos períodos. Cabe destacar que, esta premissa representa uma das principais simplificações do modelo, porém necessária para refletir alguma taxa de crescimento. Portanto, há o risco da estimativa não apresentar adequadamente o custo de capital das empresas estudadas. Em vista disto, sugere-se para futuras pesquisas a aplicação de outros modelos de custo de capital. Como sugestão para pesquisas futuras, pode-se investigar os efeitos da qualidade da informação contábil no custo de capital de terceiros, além de verificar se o impacto no custo de capital pode ser diferente entre os setores estudados.

- Variável para adoção completa (IFRS) - para mensurar o efeito da adoção completa das IFRS foi usada uma dummy que assumiu 1 para os anos de 2010 e 2011 e 0 caso contrário. Porém, é sabido que a adoção das normas internacionais pode ter sido realizada de maneira diferente entre as empresas da amostra, em função de um período de adaptação pelo qual as entidades passam nos primeiros anos de adoção. Portanto, deve-se considerar que esse efeito aprendizado pode ter influenciado a aplicação das normas, não sendo tratado nesta tese.

Apesar das limitações apresentadas, elas não invalidam os achados desta tese, uma vez que são consistentes com evidências internacionais. Ademais, o uso do portfolio approach para qualidade da informação contábil e de duas abordagens para observar custo de capital, contribuem para aumentar a validade dos resultados, além da aplicação de métodos robustos. 


\section{REFERÊNCIAS}

AGOGLIA, C. P.; DOUPNIK, T. S.; TSAKUMIS, G. T. Principles-Based versus RulesBased Accounting Standards: The Influence of Standard Precision and Audit Committee Strength on Financial Reporting Decisions. The Accounting Review. v. 86, n. 3, p. 747-767, apr. 2011.

ALALI, F. A.; FOOTE, P. S. The Value Relevance of International Financial Reporting Standards: Empirical Evidence in an Emerging Market. The International Journal of Accounting. v. 47, p. 85-108, 2012.

ALMEIDA, J. E. F. Qualidade da informação contábil em ambientes competitivos. São Paulo, 2010. Tese (Doutorado em Controladoria e Contabilidade) - Programa de PósGraduação em Ciências Contábeis, Departamento de Contabilidade e Atuária, Faculdade de Economia, Administração e Contabilidade, Universidade de São Paulo.

AMERICAN ACCOUNTING ASSOCIATION'S FINANCIAL ACCOUNTING STANDARDS COMMITTEE - AAA FASC. A Framework for Financial Reporting Standards: Issues and a Suggested Model. Accounting Horizons. v. 24, n. 3, 2010, p. 471485.

AMIR, E.; HARRIS, T. S.; VENUTI, E. K. A Comparison of the Value-Relevance of U.S. versus Non-U.S. GAAP Accounting Measures Using Form 20-F Reconciliations. Journal of Accounting Research. v. 31 Supplement, p. 230-264, 1993.

ANDERSON, C. W. Financial contracting under extreme uncertainty: an analysis of Brazilian corporate debentures. Journal of Financial Economics. v. 51, p. 45-84, 1999.

ANGRIST, J. D.; PISCHKE, J. Mostly Harmless Econometrics: An Empiricists Companion. Princeton: Princeton University Press, 2009.

ARELLANO, M. Computing robust standard errors for within-groups estimators. Oxford Bulletin of Economics and Statistics. vol. 49, p. 431-34. 1987.

ARMSTRONG, C. S.; BARTH, M. E.; JAGOLINZER, A. D.; RIEDL, E. J. Market Reaction to the Adoption of IFRS in Europe. The Accounting Review. v. 85, n.1, p.31-61, 2010.

ASSAF NETO, A. Mercado Financeiro. 6. ed. São Paulo: Atlas, 2005.

BALL, R. International Financial Reporting Standards (IFRS): pros and cons for investors. Accounting and Business Research, International Accounting Policy Forum, p. 5-27, 2006. 
BALL, R.; BROWN, P. An Empirical Evaluation of Accounting Income Numbers. Journal of Accounting Research. v. 6, p.159-178, Autumm, 1968.

BALL, R.; KOTHARI, S. P.; ROBIN, A. The effect of institutional factors on properties of accounting earnings. Journal of Accouting and Economics. v. 29, n. 1, p. 1-51, fev. 2000.

BALL, R. J.; SHIVAKUMAR, L. Earnings quality in UK private firms: comparative loss recognition timeliness. Journal of Accounting and Economics. v. 39, p. 83-128, 2005.

BALL, R.; ROBIN, A.; WU, J. S. Incentives versus standards: properties of accounting income in four East Asian countries. Journal of Accounting and Economics. v. 36, p. 235270, 2003.

BARTH, M. E. Research, Standard Setting, and Global Financial Reporting. Foundation and Trends in Accounting. v. 1, n. 2, p. 71-165, 2006.

BARTH, M. E. Global Financial Reporting: Implications for U.S. Academics. The Accounting Review. v. 83, n. 5, p. 1159-1179, 2008.

BARTH, M. E.; BEAVER, W. H.; LANDSMAN, W. R. The market valuation implications of net periodic pension cost components. Journal of Accounting and Economics. v. 15, p. 27 62, 1992.

BARTH, M. E.; BEAVER, W. H.; LANDSMAN, W. R. The relevance of the value relevance literature for financial accounting standard setting: Another view. Journal of Accounting and Economics. v. 31, n. 1-3, p. 77-104, 2001.

BARTH, M.; LANDSMAN, W. R.; LANG, M. H. International Accounting Standards and Accounting Quality. Journal of Accounting Research. v. 46, n. 3, p. 467-498, jun. 2008.

BARTH, M. E.; LANDSMAN, W. R.; LANG, M. H.; WILLIAMS, C. D., 2006. Accounting Quality: International Accounting Standards and US GAAP. Working chapter, Stanford University. Disponível em:

http://www.fox.temple.edu/conferences/cav/2008/documents/barthpaper.pdf >. Acesso: 12 maio 2012.

BARTH, M. E.; LANDSMAN, W. R.; LANG, M. H.; WILLIAMS, C. D., 2012. Are IFRSbased and US GAAP-based Accounting Amounts Comparable? Working paper, SSRN. Disponível em: <http://papers.ssrn.com/sol3/papers.cfm?abstract_id=1585404\&http://papers.ssrn.com/sol3/pa pers.cfm?abstract_id=1585404>. Acesso: 12 maio 2012.

BASU, S. The conservatism principle and the asymmetric timeliness of earnings. Journal of Accouting ang Economics, v. 24, n.1, p. 3-37, 1997. 
BEAVER, W. The information content of annual earnings announcements. Journal of Accounting Research. Supplement, p. 67-92, 1968.

BERTRAND, M.; DUFLO, E.; MULLAINATHAN, S. How much should we trust differences-in-differences estimates. Quarterly Journal of Economics. v. 119, p. 249-275, 2004.

BEYER, A.; COHEN, D. A.; LYS, T. Z.; WALTHER, B. R. The financial reporting environment: Review of the recent literature. Journal of Accounting and Economics. v. 50, p. 296-343, 2010

BINDER, J. J. The Event Study Methodology Since 1969. Review of Quantitative Finance and Accounting. v. 11, n. 2, p. 111-137, 1998.

BRAGA, J. P. Padrões Contábeis, Incentivos Econômicos e Reconhecimento Assimétrico de Perdas. São Paulo, 2011. Dissertação (Mestrado em Ciências Contábeis) - Programa de Pós Graduação em Ciências Contábeis, Departamento de Contabilidade e Atuária, Faculdade de Economia, Administração e Contabilidade, Universidade de São Paulo.

BRASIL. Lei $\mathrm{n}^{\circ} 11.638$, de 28 de dezembro de 2007. Altera e revoga dispositivos da Lei no 6.404, de 15 de dezembro de 1976, e da Lei no 6.385, de 7 de dezembro de 1976, e estende às sociedades de grande porte disposições relativas à elaboração e divulgação de demonstrações financeiras. Diário Oficial da União, Brasília, DF, 28 dez. 2007.

BRITO, G. A. S. Conservadorismo Contábil e o Custo do Crédito Bancário no Brasil. São Paulo, 2010. Tese (Doutorado em Controladoria e Contabilidade) - Programa de PósGraduação em Ciências Contábeis, Departamento de Contabilidade e Atuária, Faculdade de Economia, Administração e Contabilidade, Universidade de São Paulo.

BROOKS, C. Introductory econometrics for finance. Cambridge: Cambridge University Press, 2002.

BROWN, S.; LO, K.; LYS, T. Use of $\mathrm{R}^{2}$ in accounting research: measuring changes in value relevance over the last four decades. Journal of Accounting and Economics. v. 28, p. 83115, 1999.

BUNGE, M. Epistemologia: curso de atualização. ed. da Universidade de São Paulo, 1980.

BUNGE, M. La investigación científica: su estrategia y su filosofia. 3. ed. Siglo xxi editores, 2004. Disponível em < http://books.google.com/books?id=iDjRhR82JHYC\&printsec=frontcover\&hl\#v=onepage \&q= informaci\%C3\%B3n\&f=false>. Acesso em 12 de out. de 2011. 
BURGSTAHLER, D. C.; HAIL, L.; LEUZ, C. The Importance of Reporting Incentives: Earnings Management in Europe Private and Public Firms. The Accounting Review. v. 81, n. 5, p. 883-1016, 2006.

CAMPBELL, J. Y.; LO, A.; MACKINLEY, A. C. The Econometrics of Financial Markets. Princeton University Press, 1997.

CAPKUN, V.; CAZAVAN-JENY, A.; JEANJEAN, T.; WEISS, L. A. Earnings Management and Value Relevance during the Mandatory Transition from Local GAAPs to IFRS in Europe. April 25, 2008. Disponível em SSRN: <http://ssrn.com/abstract=1125716>. Acesso em $10 \mathrm{de}$ jan. de 2011.

CARDOSO, R. L.; MARTINEZ, A. L. Gerenciamento de resultados contábeis no Brasil mediante decisões operacionais. In: ENCONTRO ANUAL DA ASSOCIAÇÃO NACIONAL DOS PROGRAMAS DE PÓS-GRADUAÇÃO EM ADMINISTRAÇÃO - ENANPAD, 30., 2006, Salvador. Anais..., Rio de Janeiro: ANPAD, 2006.

CHALMERS, K.; CLINCH, G.; GODFREY, J. M. Adoption of International Financial Reporting Standards: impact on the value relevance of intangible assets. Australian Accounting Review. v. 18, n. 3, p. 237-247, 2008.

CHALMERS, K.; CLINCH, G.; GODFREY, J. M. Change in value relevance of accounting information upon IFRS adoption: Evidence from Australia. Australian Journal of Management. v. 36, n. 2, p. 151-173, 2011.

CHEN, F.; HOPE, O. K.; LI, Q.; WANG, X. Financial Reporting Quality and Investment Efficiency of Private Firms in Emerging Markets. The Accouting Review. v. 86, n. 4, p. 1255- 1288, 2011.

CHONG, A.; LOPEZ-DE-SILANES, F. Corporate Governance in Latin America. Research Department Working paper series. Washington: Inter- American Development Bank, 2007. Disponível em <http://www.iadb.org/res/publications/pubfiles/pubWP-591.pdf>. Acesso: 01 ago 2012.

CHRISTENSEN, H. B.; LEE, E.; WALKER, M. Incentives or standards: What determines accounting quality changes around IFRS adoption? Working Paper, 2008. Disponível em SSRN: <http://papers.ssrn.com/sol3/papers.cfm?abstract_id=1013054>. Acesso: 25 maio 2012.

CHRISTIE, A. A. On Cross-sectional Analysis in Accounting Research. Journal of Accounting and Economics. v. 9, p. 231-258, 1987.

CLARKSON, P.; HANNA, J. D.; RICHARDSON, G. D.; THOMPSON, R. The impact of IFRS adoption on the value relevance of book value and earnings. Journal of Contemporary Accounting and Economics. v. 7, p. 1-17, 2011. 
COELHO, A. C. D. Qualidade informacional e conservadorismo nos resultados contábeis publicados no Brasil. São Paulo, 2007. Tese (Doutorado em Controladoria e Contabilidade) - Programa de Pós-Graduação em Ciências Contábeis, Departamento de Contabilidade e Atuária, Faculdade de Economia, Administração e Contabilidade, Universidade de São Paulo.

CORMIER, D.; DEMARIA, S.; LAPOINTE-ANTUNES, P.; TELLER, R. First-Time Adoption of IFRS, Managerial Incentives, and Value-Relevance: Some French Evidence. Journal of International Accounting Research. v. 8, n. 2, p. 1-22, 2009.

COSTA, F. M.; REIS, D. J. S.; TEIXEIRA, A. M. C. Implicações de Crises Econômicas na Relevância da Informação Contábil das Empresas Brasileiras. Revista de Educação e Pesquisa em Contabilidade. v. 6, n. 2, p. 141-153, abr./jun. 2012.

PRONUNCIAMENTOS BÁSICOS (R1) - CPC 00 - Estrutura Conceitual para Elaboraçãoe Divulgação de Relatório Contábil-Financeiro, de 02 de dezembro de 2011. Brasília, DF. Disponível em: <http://www.cpc.org.br/pdf/CPC00_R1.pdf>. Acesso em 01 setembro de 2012.

DAlMÁCIO, F. Z. Mecanismos de Governança e Acurácia das Previsões dos Analistas do Mercado Brasileiro: uma Análise sob a Perspectiva da Teoria da Sinalização. São Paulo, 2009. Tese (Doutorado em Controladoria e Contabilidade) - Programa de PósGraduação em Ciências Contábeis, Departamento de Contabilidade e Atuária, Faculdade de Economia, Administração e Contabilidade, Universidade de São Paulo.

DASKE, H.; HAIL, L.; LEUZ, C.; VERDI, R. Mandatory IFRS Reporting around the World: Early Evidence on the Economic Consequences. Journal of Accounting Research. v. 46, n. 5, p. 1085-1142, 2008.

DECHOW, P M. Accounting Earnings and Cash Flows as Measures of Firm Performance: the role of accounting accruals. Journal of Accounting and Economics. v. 18, p.3-42, 1994.

DECHOW, P. M.; DICHEV, I. D. The quality of accruals and earnings: the role of accounting accruals estimation errors. The Accounting Review. v. 77, p. 35-59, 2002.

DECHOW, P. M.; GE, W.; SCHRAND, C. Understanding earnings quality: A review of the proxies, their determinants and their consequences. Journal of Accounting and Economics. v. 50, p. 344-401, 2010.

DECHOW, P. M.; SKINNER, D. J. Eanings Management: Reconciling the Views of Accounting, Practitioners, and Regulators. Accounting Horizons. v. 14, n. 2, p. 235-250, jun 2000.

DECHOW, P.; SLOAN, R.; SWEENEY, A. Detecting earnings management. The Accounting Review. v. 70, n. 2, p.193-225, 1995. 
DEFOND, M. L. Earnings quality research: Advances, challenges and future research. Journal of Accounting and Economics. v. 50, p. 402-409, 2010.

DEVAlLE, A.; ONALI E.; MAGARINI, R. Assessing the Value Relevance of Accounting Data After the Introduction of IFRS in Europe. Journal of International Financial Management \& Accounting. v. 21, n. 2, p. 85-119, 2010.

DOUPNIK, T. S.; SALTER, S. B. An Empirical Test of a Judgmental International Classification of Financial Reporting Practices. Journal of International Business Studies. v. 24, n. 1, p. 41-60, 1993.

EASTON, P. PE ratios, PEG ratios, and estimating the implied expected rate of return on equity capital. The Accounting Review, v. 79, n. 1, p. 73-95, 2004.

EASTON, P. D. Security Returns and the Value Relevance of Accounting Data. Accounting Horizons. v. 13, n. 4, p. 399-412, dez. 1999.

EASTON, P. Estimating the Cost of Capital Implied by Market Prices and Accounting Data. Foundation and Trends in Accounting. v. 2, n. 4, p. 241-364, 2009.

FAMA, E. F. The behavior of stock market prices. Journal of Business. v. 38, p. 34-105, jan. 1965.

FAMA, E. F.; FISHER, L.; JENSEN, M. C.; ROLL, R. The Adjustment of Stock Prices to New Information. International Economic Review. v. 10, n. 1, p. 1-21, 1969.

FAVERO, L. P.; BElfiORE, P.; SILVA, F. L.; CHAN, B. L. Análise de Dados: modelagem multivariada para tomada de decisões. Rio de Janeiro: Elsevier, 2009.

FELTHAM, G. A.; OHLSON, J. Valuation and clean surplus accounting for operating and financial activities. Contemporary Accounting Research. 11 (Spring): 689-732, 1995.

FIELD, T. D.; LYS, T. Z.; VINCENT, L. Empirical Research on Accounting Choice. Journal of Accounting and Economics. v. 31, p. 255-307, 2001.

FIFIELD, S.; FINNINGHAM, G.; FOX, A.; POWER, D.; VENEZIANI, M. A cross-country analysis of IFRS reconciliation statements. Journal of Applied Accounting Research. v. 12, n. 1, p. 26-42, 2011.

FORMIGONI, H.; PAULO, E.; PEREIRA, C. A. Estudo sobre o gerenciamento de resultados contábeis pelas companhias abertas e fechadas brasileiras. In: CONGRESSO ANPCONT, 1., 2007, Gramado. Anais... São Paulo: ANPCONT, 2007. 
FRANCIS, J.; LAFOND, R.; OLSSON, P. M.; SCHIPPER, K. The market pricing of accrual quality. Journal of Accounting and Economics. v. 39, p. 295-327, mar. 2005.

FRANCIS, J. R. MARTIN, X. Acquisition profitability and timely loss recognition. Journal of Accounting and Economics. v. 49, p. 161-178, 2010.

FRANCIS, J.; OLSSON, P.; SCHIPPER, K. Earnings Quality. Foundations and Trends in Accounting. v. 4, n. 4, p. 259-340, 2008.

GABRIEL, F. Impacto da Adesão às Práticas Recomendadas de Governança Corporativa no Índice de Qualidade da Informação Contábil. São Paulo, 2011. Tese (Doutorado em Controladoria e Contabilidade) - Programa de Pós-Graduação em Ciências Contábeis, Departamento de Contabilidade e Atuária, Faculdade de Economia, Administração e Contabilidade, Universidade de São Paulo.

GAO, P. Disclosure Quality, Cost of Capital, and Investor Welfare. The Accounting Review. v. 85, n. 1, 1-29, jan. 2010.

GJERDE, O.; KNIVSFLA, K.; SAETTEM, F. The Value-Relevance of Adopting IFRS: Evidence from 145 NGAAP Restatements. Journal of International Accounting, Auditing and Taxation, n. 17, p. 92-112, 2008.

GOH, B. W.; LI, D. Internal Controls and Conditional Conservatism. The Accounting Review. v. 86, n. 3, 975-1005, abril 2011.

GORDON, M. J. Postulates, Principles and Research in Accounting. Accounting Review, v. 39, p. 251-263, abr. 1964 apud WATTS, R. L, ZIMMERMAN, J. L. Positive Accounting Theory. New Jersey: Prentice-Hall, 1986.

Gujarati, D. Econometria Básica. São Paulo: Makron Books. Quarta Edição, 2006.

HAIL, L.; LEUZ, C. International differences in the cost of equity capital: Do legal institutions and securities regulation matter? Journal of Accounting Research, v. 44, p. 485531, 2006.

HAIL, L.; LEUZ, C. Cost of capital effects and changes in growth expectations around U.S. cross-listings. Journal of Financial Economics. v. 93, n. 3, p. 428-454, set. 2009.

HARRIS, M. S.; MULLER, K. A. The market valuation of IAS versus US-GAAP accounting measures using Form 20-F reconciliations. Journal of Accounting and Economics. v. 26, p. 285-312, 1999.

HEALY, P. M.; WAHLEN, J. M. A Review of the Earnings Management Literature and its Implications for Standard Setting. Accounting Horizons. v. 13, n. 4, p. 365-383, dez 1999. 
HELLMAN, N. Soft Adoption and Reporting Incentives: A Study of the Impact of IFRS on Financial Statements in Sweden. Journal of International Accounting Research. v. 10, n. 1, p. 61-83, 2011.

HENDRIKSEN, E. S.; VAN BREDA, M. E. Teoria da Contabilidade. São Paulo: Atlas, 1999.

HOLTHAUSEN, R. W. Accounting Standards, Financial Reporting Outcomes and Enforcement. Journal of Accounting Research. v. 47, p. 447-458, 2009.

HOLTHAUSEN, R. W.; WATTS, R. L. The relevance of value-relevance literature for financial accounting standard setting. Journal of Accounting and Economics. v. 31, p. 3-75, 2001.

HORTON, J.; SERAFEIM, G. Market reaction to and valuation of IFRS reconciliation adjustments: first evidence from the UK. Review of Accounting Studies. v. 15, n. 4, p. 725 $751,2009$.

HORTON, J.; SERAFEIM, G.; SERAFEIM, I. Does Mandatory IFRS Adoption Improve the Information Environment? Contemporary Accounting Research. 2012.

INTERNATIONAL FINANCIAL REPORTING STANDARDS - IFRS. Who we are and what we do. 2011. Disponível em <http://www.ifrs.org >. Acesso em: 21 jul. 2011.

INTERNATIONAL FINANCIAL REPORTING STANDARDS (IFRS). A welcome from the incoming Chairman of the IASB. Disponível em <http://www.ifrs.org/News/Features/welcome+Chairman+IASB.htm>. Acesso em: 21 jul. 2011.

INTERNATIONAL FINANCIAL REPORTING STANDARDS (IFRS). Response to US SEC publication of staff report on IFRS, jul. 2012. Disponível em <http://www.ifrs.org/Alerts/Governance/ResponseUSSECstaffreport.htm>. Acesso: 21 jul. 2012.

INTERNATIONAL FINANCIAL REPORTING STANDARDS (IFRS). The Concept of Prudence: dead or alive? set. 2012. Disponível em <http://www.ifrs.org/Alerts/PressRelease/Documents/2012/Concept\%20of\%20Prudence\%20s peech.pdf $>$. Acesso: 22 set. 2012.

IQUIAPAZA, R. A.; BARBOSA, F. V.; BRESSAN, A. A. Testes de Não Estacionariedade em Séries Financeiras com Dados em Painel: Uma Síntese Aplicada. In: Reunión Anual de Cladea, 39., 2004, Puerto Plata. Anais..., 2004. 
IUDÍCIBUS, S.; LOPES, A. B. Teoria Avançada da Contabilidade. Atlas: São Paulo, 2004.

IUDÍCIBUS, S; MARTINS, E.; GELBCKE, E. R.; SANTOS, A. Manual de Contabilidade Societária. São Paulo: Atlas, 2010.

JENSEN, M. C.; MECKLING, W. H. Theory of the firm: managerial behavior, agency costs and ownership structure. Journal of Financial Economics. Amsterdam, v. 3, n. 4, p. 305360, out. 1976.

JENSEN, M.; MECKLING, W. H. The nature of man. Journal of Applied Corporate Finance. v. 7, n. 2, p. 4-19, 1998.

JONES, J. J. Earnings management during import relief investigations. Journal of Accounting Research. v. 29, n. 2, p. 193-228, out., 1991.

JONES, J. J. Earnings management during import relief investigations. Journal of Accounting Research. Oxford. v. 33, n. 2, p. 353-367, autumn 1995.

KANG, S.; SIVARAMAKRISHNAN, K. Issues in testing earnings management and an instrumental variable approach. Journal of Accounting Research. Oxford. v. 33, n. 2, p. 353-367, autumn 1995.

KHURANA, I. K.; MICHAS, P. Mandatory IFRS Adoption and the U.S. Home Bias. Working Paper, 2011. Disponível em http://papers.ssrn.com/sol3/papers.cfm?abstract_id=1872239>. Acesso: 24 abril 2012.

KOTHARI, S. P. Capital markets research in accounting. Journal of Accounting and Economics. v. 31, p. 105-231, 2001.

KOTHARI, S. P.; RAMANNA, K.; SKINNER, D. J. Implications for GAAP from an analysis of positive research in accounting. Journal of Accounting and Economics. v. 50, p. 246286, 2010.

KOTHARI, B. R.; ROBIN, A. The Effect of International Institutional Factors on Properties of Accounting Earnings. Journal of Accounintg and Economics. v. 29, p. 1-51, 2000.

KOTHARI, S. P.; ZIMMERMAN, J. L. Price and return models. Journal of Accounting and Economics. v. 20, p. 155-192, 1995.

KPMG. A Governança Corporativa e o Mercado de Capitais: Um panorama das corporações brasileiras na BMF\&FBOVESPA e nas Bolsas norte-americanas. Versão 2009/2010.

Disponível

em <http://www.kpmg.com.br/aci/publicacoes/2009/Estudo_GC2009.pdf>. Acesso: 01 set. 2009. 
KPMG. SEC Statement Provides Plan for 2011 Decision on IFRS Implementation in the U.S. maio 2010.20 Disponível em <http://www.kpmg.com/US/en/IssuesAndInsights/ArticlesPublications/Documents/fei-ifrsfinancial-reporting.pdf>. Acesso: 21 jul. 2012.

KVAAL, E.; NOBES, C. International differences in IFRS policy choice. Accounting and Business Research. v. 40, n. 2, p.173-187, 2010.

LA PORTA, R.; LOPEZ-DE-SILANES, F.; SHLEIFER, A.; VISHNY, R. Legal Determinants of External Finance. The Journal of Finance. v. 52, n. 3, p. 1131-1150, 1997.

LA PORTA, R.; LOPEZ-DE-SILANES, F.; SHLEIFER, A. Law and Finance. Journal of Political Economy. v. 106, n. 6, p. 1113-1155, 1998.

LA PORTA, R.; LOPEZ-DE-SILANES, F.; SHLEIFER, A. Corporate Ownership Around the World. The Journal of Finance. v. 54, n. 2, p. 471-517, 1999.

LAMBERT, R. Discussion of "Implications for GAAP from an analysis of positive research in accounting". Journal of Accounting and Economics. v. 50, p. 287-295, 2010.

LANG, M.; RAEDY, J. S.; WILSON, W. Earnings Management and Cross Listing: are reconciled earnings comparable to US earnings? Journal of Accounting and Economics. v. 42, p. 255-283, 2006.

LANZANA, A. P. Relação entre disclosure e governança corporativa das empresas brasileiras. São Paulo, 2004. Dissertação (Mestrado em Administração) - Programa de PósGraduação em Administração, Departamento de Administração, Faculdade de Economia, Administração e Contabilidade, Universidade de São Paulo.

LARCKER, D. F.; RUSTICUS, T. O. On the use of instrumental variables in accounting research. Journal of Accounting and Economics. v. 49, p. 186-250, 2010.

LEE, E.; WALKER, M.; CHRISTENSEN, H. B. Mandating IFRS: Its Impact on the Cost of Equity Capital in Europe. Journal of International Accounting Research. v. 9, n.1, 2010.

LI, S. Does Mandatory Adoption of International Financial Reporting Standards in the European Union Reduce the Cost of Equity Capital? The Accounting Review. v. 85, n. 2, p. 607-636, 2010.

LIMA, J. B. N. A Relevância da Informação Contábil e o Processo de Convergência Para as Normas IFRS no Brasil. São Paulo, 2010. Tese (Doutorado em Controladoria e Contabilidade) - Programa de Pós-Graduação em Ciências Contábeis, Departamento de Contabilidade e Atuária, Faculdade de Economia, Administração e Contabilidade, Universidade de São Paulo. 
LIMA, V. S. Incentivos no Nível da Firma e Consequências Econômicas da Convergência ao IFRS no Brasil. São Paulo, 2011. Dissertação (Mestrado em Ciências Contábeis) - Programa de Pós-Graduação em Ciências Contábeis, Departamento de Contabilidade e Atuária, Faculdade de Economia, Administração e Contabilidade, Universidade de São Paulo.

LIU, J.; LIU, C. Value Relevance of Accounting Information in Different Stock Market Segments: The Case of Chinese A-, B-, and H-Shares. Journal of International Accounting Research. v. 6, n. 2, p. 55-81, 2007.

LOPES, A. B. A Relevância da Informação Contábil para o Mercado de Capitais: o modelo de Ohlson aplicado à Bovespa. São Paulo, 2001. Tese (Doutorado em Ciências Contábeis) - Programa de Pós-Graduação em Ciências Contábeis, Departamento de Contabilidade e Atuária, Faculdade de Economia, Administração e Contabilidade, Universidade de São Paulo.

LOPES, A. B. Financial Accounting in Brazil: An Empirical Examination. Latin American Business Review. v. 6, p.45-68, 2005.

LOPES, A. B. The relation between firm-specific corporate governance, cross listing and the Informativeness of accounting numbers in Brazil. Manchester, 2008. Tese (Doutorado em Accounting and Finance). Manchester Business School - University of Manchester

LOPES, A. B.; de ALENCAR, R. C. Disclosure and cost of equity capital in emerging markets: The Brazilian case. The International Journal of Accounting, v. 45, n. 4, p. 443464, 2010.

LOPES, A. B.; MARTINS, E. Teoria da Contabilidade: uma nova abordagem. São Paulo: Atlas, 2005.

LOPES, A. B.; WALKER, M. Firm-Level Incentives and the Informativeness of Accounting Reports: An Experiment in Brazil (February 1, 2008). Available at SSRN: <http://ssrn.com/abstract=1095781>. Acesso: 02 mai. 2012.

MADDALA, G. S.; WU, S. A comparative study of unit root tests whit panel data and a new simple test. Oxford Bulletin of Economics and Statistics, v. 61, p. 631-652, 1999.

MAINES, L. A.; BARTOV, E.; FAIRFIELD, P.; HIRST, D. E.; IANNACONI, T. E.; MALLETT, R.; SCHRAND, C. M.; SKINNER, D.; VINCENT, L. Evaluating concepts-based vs. rules-based approaches to standard setting. Accounting Horizons. v. 17, n. 1, p. 73-89, 2003.

MARTINEZ, A. L. Gerenciamento dos resultados contábeis: estudo empírico das companhias abertas brasileiras. São Paulo, 2001. Tese (Doutorado em Ciências Contábeis) 
- Programa de Pós-Graduação em Ciências Contábeis, Departamento de Contabilidade e Atuária, Faculdade de Economia, Administração e Contabilidade, Universidade de São Paulo.

MARTINEZ, A. L. Detectando earnings management no Brasil: estimando os accruals discricionários. Revista de Contabilidade e Finanças. São Paulo, v. 19, p.7-17, jan./abr. 2008.

MARTINS, G. A.; THEÓPHILO, C. R. Metodologia da investigação científica para ciências sociais aplicadas. 2. ed. São Paulo: Atlas, 2009.

MCNICHOLS, M. F. Discussion of the quality of accruals and earnings: The role of accrual estimation errors.The Accouting Review. v. 77, supplement, p. 61-69, 2002.

MCNICHOLS, M. F.; STUBBEN, S. R. Does earnings management affect firms' investment decisions.The Accouting Review. v. 83, n. 6, p. 1571-1603, 2008.

MEULEN, S. V.; GAEREMYNCK, A.; WILLEKENS, M. Attribute differences between U.S. GAAP and IFRS earnings: An exploratory study. The International Journal of Accounting, v. 42, n. 2, p. 123-142, 2007.

MILLER, M. H.; MODIGLIANI, F. Dividend Policy, Growth, and the Valuation of Shares. The Journal of Business. v. 34, n. 4, p. 411- 433, out. 1961.

NELSON, M. W.; ELLIOTT, J. A.; TARPLEY, R. L. Evidence from auditors about managers' and auditor's earnings management decisions. The Accounting Review, v. 77, Supplement, p. 175-202, 2002.

NARDI, P. C. C. Gerenciamento de resultados contábeis e a relação com o custo da dívida das empresas brasileiras de capital aberto. Ribeirão Preto, 2008. Dissertação (Mestrado em Controladoria e Contabilidade) - Programa de Pós-Graduação em Ciências Contábeis, Departamento de Cicências Contábeis, Faculdade de Economia, Administração e Contabilidade de Ribeirão Preto, Universidade de São Paulo.

NARDI, P. C. C.; NAKAO, S. H. Gerenciamento de resultados e a relação com o custo da dívida das empresas brasileiras abertas. Revista de Contabilidade e Finanças. v. 20, n. 51, São Paulo set./dez, 2009.

NARDI, P. C. C.; SILVA, R. L. M.; NAKAO, S. H.; VALLE, M. R. A Relação entre Gerenciamento de Resultados Contábeis e o Custo de Capital das Companhias Abertas Basileiras. Revista Universo Contábil. v. 5, n. 4, p. 06-26, out./dez., 2009.

NIYAMA, J. K. Contabilidade Internacional. 1. ed. São Paulo: Atlas, 2008. 
NOBES, C. International Classification of Financial Reporting. 2. ed. Londres: Routledge, 1992.

OHLSON, J. Earnings, book values and dividends in security valuation. Contemporary Accounting Research. v. 11 (Spring): p. 661-687, 1995.

OHLSON, J. A.; GAO, Z. O Lucro, seu Crescimento e o Valor da Empresa. Atlas: São Paulo, 2008.

OHLSON, J. A.; LOPES, A. B. Avaliação de Empresas com Base em Números Contábeis. Brazilian Business Review, v. 4, n. 2, p. 96-103, mai/ago, 2007.

OHLSON, J. A.; NAUROTH-JUETTNER, B. E. Expected EPS and EPS Growth as Determinants of Value. Review of Accounting Studies. v. 10, p. 349-365, 2005.

PAANANEN, M.; LIN, H. The Development of Accounting Quality of IAS and IFRS over Time: the case of Germany. Journal of International Accounting Research. v. 8, n. 1, p. 31-55, 2009.

PAUlO, E.; ANTUNES, M. T. P.; FORMIGONI, H. Conservadorismo Contábil nas Companhias Abertas e Fechadas Brasileiras. Revista de Administração de Empresas RAE, v. 48, n.3, p.46-60, jul./set. 2008.

PAULO, E. Manipulação das informações contábeis: uma análise teórica e empírica sobre os modelos operacionais de detecção de gerenciamento de resultados. São Paulo, 2007.Tese (Doutorado em Contabilidade) - Programa de Pós-Graduação em Ciências Contábeis, Departamento de Contabilidade e Atuária, Faculdade de Economia, Administração e Contabilidade, Universidade de São Paulo.

PAULO, E.; CORRAR, L. J.; MARTINS, E. Detectando gerenciamento de resultados pela análise do diferimento tributário. In: ENCONTRO ANUAL DA ASSOCIAÇÃO NACIONAL DOS PROGRAMAS DE PÓS-GRADUAÇÃO EM ADMINISTRAÇÃO - ENANPAD, 30., 2006, Salvador. Anais... Bahia, 2006.

PENMAN, S. H.; ZHANG, X. J. Accounting conservatism, the quality of earnings, and stock returns. The Accounting Review. v. 77, n. 2, p. 237-264, 2002.

PRATHER-KINSEY, J., JERMAKOWICZ, E. K., VONGPHANITH, T. Capital Market Consequences of European Firms' Mandatory Adoption of IFRS. American Accounting Association, Anaheim, CA. August 3-6, 2008. Disponível em <http://aaahq.org/AM2008/abstract.cfm?submissionID=808>. Acesso em 10 de jan. de 2011.

SECURITIES AND EXCHANGE COMMISSION - SEC, jul. 2012. Work Plan for the Consideration of Incorporating International Financial Reporting Standards into the Financial $\begin{array}{llllll}\text { Reporting System for } & \text { U.S. Issuers. }\end{array}$ 
<http://www.sec.gov/spotlight/globalaccountingstandards/ifrs-work-plan-final-report.pdf>. Acesso: 20 jul. 2012.

SILVEIRA, A. M. Governança Corporativa e Estrutura de Propriedade: determinantes e relação com o desempenho das empresas no Brasil. São Paulo, 2004. Tese (Doutorado em Administração) - Programa de Pós-Graduação em Ciências Contábeis, Departamento de Contabilidade e Atuária, Faculdade de Economia, Administração e Contabilidade, Universidade de São Paulo.

SLOAN, R. Do Stock Prices Fully Reflect Information in Accuals and Cash Flows About Future Earnings? The Accounting Review. v. 71, n. 3, p. 289-315, jul 1996.

SODERSTROM, N. S.; SUN, K. J. IFRS Adoption and Accounting Quality: A Review. European Accounting Review. v. 16, n. 4, p. 675-702, 2007.

TENDELOO, B. V.; VANSTRAELEN, A. Earnings Management under German GAAP versus IFRS. European Accouting Review. v. 14, n. 1, p. 155-180, 2005.

TEOH, S. H.; WELCH, I.; WONG, T. J. W. Earnings management and the long run underperformance of seasoned public offerings. Journal of Financial Economics. v. 50, p. 63-99. 1998.

TORRES, F. Adaptação Plena ao Padrão IFRS ainda vai Demorar. Jornal Valor Econômico, p. D4, 21/09/2011.

TWEEDIE, D. Prepared statement of Sir David Tweedie, Chairman of the International Accounting Standards Board before the Economic and Monetary Affairs Committee of the European Parliament. 2006. Disponível em http://www.iasplus.com/resource/0601tweedieeuspeech.pdf >. Acesso em 10 Out. de 2011.

WALKER, M. Accounting for Varieties of Capitalism: the case against a single set of global accounting standards. The British Accounting Review. v. 42, n. 3, p. 137-152, 2010.

WATTS, R. L. Accounting Choice Theory and Market-Based Research In Accounting. British Accounting Review. v. 24, p. 235-267, 1992.

WATTS, R. L. Conservatism in Accounting Part I: Explanations and Implications. Accounting Horizons. v. 17, n. 3, p. 207-221, 2003.

WATTS, R. L.; ZIMMERMAN, J. L. Positive Accounting Theory. New Jersey: PrenticeHall, 1986.

WHITE, H. A Heteroskedasticity-Consistent Covariance Matrix Estimator and a Direct Test for Heteroskedasticity. Econometrica. n. 4, v. 48, p. 817-838, maio, 1980. 
WHITE, H. Estimation, Inference and Specification Analysis. Cambridge: Cambridge University Press, 1994.

WOOLDRIDGE, J. M. Econometric analysis of cross-section and panel data. Cambridge: MIT Press, 2002.

YIP, W. Y. The Effects of IFRS Adoption on Cross-border Information Comparability and Economic Activity. Hong Kong, 2010. Tese (Doctor of Philosophy in Accountancy) - The Chinese University of Hong Kong. 


\section{APÊNDICE}

APÊNDICE 1 - Companhias abertas que divulgaram em IFRS, classificadas em obrigatórias e voluntárias, com seus respectivos períodos de adoção inicial.

Tabela 46 - Empresas da amostra e suas respectivas datas de adoção inicial das IFRS

\begin{tabular}{|c|c|c|c|c|c|}
\hline Adoção & Empresa & Código & Setor & $\begin{array}{c}\text { Período de } \\
\text { adoção } \\
\text { inicial }\end{array}$ & $\begin{array}{c}\text { Data de } \\
\text { Divulgação }\end{array}$ \\
\hline OBR & AES TIETE & GETI4 & Energia Elétrica & 2010 & $24 / 03 / 2011$ \\
\hline OBR & ALL AMER LAT & ALLL3 & Transporte Serviç & 2010 & $02 / 03 / 2011$ \\
\hline OBR & AMIL & AMIL3 & Outros & 2010 & $22 / 03 / 2011$ \\
\hline OBR & ANHANGUERA & AEDU3 & Outros & 2010 & $30 / 03 / 2011$ \\
\hline OBR & B2W VAREJO & BTOW3 & Comércio & 2010 & $18 / 03 / 2011$ \\
\hline OBR & BANRISUL & BRSR6 & Finanças e Seguros & 2010 & $14 / 02 / 2011$ \\
\hline OBR & BMFBOVESPA & BVMF3 & Finanças e Seguros & 2010 & $17 / 02 / 2011$ \\
\hline OBR & BR BROKERS & BBRK3 & Outros & 2010 & $23 / 03 / 2011$ \\
\hline OBR & BRADESCO & BBDC4 & Finanças e Seguros & 2010 & $31 / 01 / 2011$ \\
\hline OBR & BRADESPAR & BRAP4 & Outros & 2010 & $24 / 03 / 2011$ \\
\hline OBR & BRASIL & BBAS3 & Finanças e Seguros & 2010 & $17 / 02 / 2011$ \\
\hline OBR & BRASIL TELEC & OIBR4 & Telecomunicações & 2010 & $19 / 03 / 2011$ \\
\hline OBR & BRASKEM & BRKM5 & Química & 2010 & $17 / 03 / 2011$ \\
\hline OBR & BRF FOODS & BRFS3 & Alimentos e Beb & 2010 & $24 / 03 / 2011$ \\
\hline OBR & BROOKFIELD & BISA3 & Construção & 2010 & $29 / 03 / 2011$ \\
\hline OBR & CCR SA & CCRO3 & Transporte Serviç & 2010 & $17 / 03 / 2011$ \\
\hline OBR & CEMIG & CMIG4 & Energia Elétrica & 2010 & $29 / 03 / 2011$ \\
\hline OBR & CESP & CESP6 & Energia Elétrica & 2010 & $31 / 03 / 2011$ \\
\hline OBR & CETIP & CTIP3 & Finanças e Seguros & 2010 & $29 / 03 / 2011$ \\
\hline OBR & CIA HERING & HGTX3 & Textil & 2010 & 03/03/2011 \\
\hline OBR & CONFAB & CNFB4 & Siderur \& Metalur & 2010 & $21 / 02 / 2011$ \\
\hline OBR & COPEL & CPLE6 & Energia Elétrica & 2010 & $28 / 03 / 2011$ \\
\hline OBR & COSAN & CSAN3 & Alimentos e Beb & 2010 & 07/06/2011 \\
\hline OBR & CPFL ENERGIA & CPFE3 & Energia Elétrica & 2010 & $28 / 03 / 2011$ \\
\hline OBR & CYRELA REALT & CYRE3 & Construção & 2010 & $28 / 03 / 2011$ \\
\hline OBR & DASA & DASA3 & Outros & 2010 & $18 / 03 / 2011$ \\
\hline OBR & DURATEX & DTEX3 & Outros & 2010 & $15 / 02 / 2011$ \\
\hline OBR & ECODIESEL & VAGR3 & Outros & 2010 & $30 / 03 / 2011$ \\
\hline OBR & ECORODOVIAS & ECOR3 & Transporte Serviç & 2010 & $22 / 03 / 2011$ \\
\hline OBR & ELETROBRAS & ELET6 & Energia Elétrica & 2010 & $13 / 05 / 2011$ \\
\hline OBR & ELETROPAULO & ELPL4 & Energia Elétrica & 2010 & $23 / 03 / 2011$ \\
\hline OBR & EMBRAER & EMBR3 & Veiculos e peças & 2010 & $24 / 03 / 2011$ \\
\hline OBR & ENERGIAS BR & ENBR3 & Energia Elétrica & 2010 & $02 / 03 / 2011$ \\
\hline OBR & EVEN & EVEN3 & Construção & 2010 & $28 / 03 / 2011$ \\
\hline OBR & GAFISA & GFSA3 & Construção & 2010 & $28 / 03 / 2011$ \\
\hline OBR & HYPERMARCAS & HYPE3 & Outros & 2010 & $14 / 03 / 2011$ \\
\hline OBR & IOCHP-MAXION & MYPK3 & Veiculos e peças & 2010 & $23 / 02 / 2011$ \\
\hline OBR & ITAUSA & ITSA4 & Outros & 2010 & $29 / 03 / 2011$ \\
\hline OBR & ITAUUNIBANCO & ITUB4 & Finanças e Seguros & 2010 & $22 / 02 / 2011$ \\
\hline
\end{tabular}




\begin{tabular}{|c|c|c|c|c|c|}
\hline OBR & KLABIN S/A & KLBN4 & Papel e Celulose & 2010 & $24 / 02 / 2011$ \\
\hline OBR & LIGHT S/A & LIGT3 & Energia Elétrica & 2010 & 28/03/2011 \\
\hline OBR & LLX LOG & LLXL3 & Outros & 2010 & $24 / 03 / 2011$ \\
\hline OBR & LOCALIZA & RENT3 & Outros & 2010 & $04 / 03 / 2011$ \\
\hline OBR & LOJAS AMERIC & LAME4 & Comércio & 2010 & $18 / 03 / 2011$ \\
\hline OBR & MARFRIG & MRFG3 & Alimentos e Beb & 2010 & $31 / 03 / 2011$ \\
\hline OBR & MMX MINER & MMXM3 & Mineração & 2010 & $23 / 03 / 2011$ \\
\hline OBR & MPX ENERGIA & MPXE3 & Energia Elétrica & 2010 & $24 / 03 / 2011$ \\
\hline OBR & MRV & MRVE3 & Construção & 2010 & $30 / 03 / 2011$ \\
\hline OBR & MULTIPLAN & MULT3 & Outros & 2010 & $14 / 03 / 2011$ \\
\hline OBR & ODONTOPREV & ODPV3 & Outros & 2010 & $14 / 03 / 2011$ \\
\hline OBR & OGX PETROLEO & OGXP3 & Petróleo e Gas & 2010 & $25 / 03 / 2011$ \\
\hline OBR & P.ACUCAR-CBD & PCAR4 & Comércio & 2010 & $24 / 02 / 2011$ \\
\hline OBR & PANAMERICANO & BPNM4 & Finanças e Seguros & 2010 & $15 / 02 / 2011$ \\
\hline OBR & PARANAPANEMA & PMAM3 & Siderur \& Metalur & 2010 & $28 / 03 / 2011$ \\
\hline OBR & PDG REALT & PDGR3 & Construção & 2010 & $21 / 03 / 2011$ \\
\hline OBR & PORTO SEGURO & PSSA3 & Finanças e Seguros & 2010 & $26 / 02 / 2011$ \\
\hline OBR & POSITIVO INF & POSI3 & Eletroeletrônicos & 2010 & $01 / 03 / 2011$ \\
\hline OBR & RANDON PART & RAPT4 & Veiculos e peças & 2010 & $16 / 03 / 2011$ \\
\hline OBR & REDECARD & RDCD3 & Software e Dados & 2010 & $02 / 02 / 2011$ \\
\hline OBR & ROSSI RESID & RSID3 & Construção & 2010 & $24 / 03 / 2011$ \\
\hline OBR & SABESP & SBSP3 & Outros & 2010 & $29 / 03 / 2011$ \\
\hline OBR & SANTANDER BR & SANB11 & Finanças e Seguros & 2010 & $03 / 02 / 2011$ \\
\hline OBR & SID NACIONAL & CSNA3 & Siderur \& Metalur & 2010 & $28 / 03 / 2011$ \\
\hline OBR & SUL AMERICA & SULA11 & Finanças e Seguros & 2010 & $24 / 02 / 2011$ \\
\hline OBR & SUZANO PAPEL & SUZB5 & Papel e Celulose & 2010 & $01 / 03 / 2011$ \\
\hline OBR & TELEMAR & TNLP4 & Telecomunicações & 2010 & $01 / 04 / 2011$ \\
\hline OBR & TELEMAR N L & TMAR5 & Telecomunicações & 2010 & $28 / 03 / 2011$ \\
\hline OBR & TIM PART S/A & TCSL4 & Telecomunicações & 2010 & $22 / 02 / 2011$ \\
\hline OBR & TRACTEBEL & TBLE3 & Energia Elétrica & 2010 & $04 / 02 / 2011$ \\
\hline OBR & TRAN PAULIST & TRPL4 & Energia Elétrica & 2010 & $28 / 03 / 2011$ \\
\hline OBR & ULTRAPAR & UGPA4 & Química & 2010 & $24 / 02 / 2011$ \\
\hline OBR & VALEFERT & FFTL4 & Química & 2010 & $24 / 03 / 2011$ \\
\hline OBR & Vivo & VIVO4 & Telecomunicações & 2010 & $24 / 02 / 2011$ \\
\hline OBR & WEG & WEGE3 & Máquinas Indust & 2010 & $23 / 02 / 2011$ \\
\hline VOL & AMBEV & AMBV4 & Alimentos e Beb & 2008 & $18 / 05 / 2009$ \\
\hline VOL & BR MALLS PAR & BRML3 & Outros & 2009 & $13 / 04 / 2010$ \\
\hline VOL & CIELO & CIEL3 & Software e Dados & 2009 & $24 / 02 / 2010$ \\
\hline VOL & COMGÁS & CGAS5 & Petróleo e Gas & 1o. Tri 2010 & $27 / 07 / 2010$ \\
\hline VOL & COPASA & CSMG3 & Outros & 2009 & $28 / 03 / 2010$ \\
\hline VOL & ESTACIO SA & ESTC3 & Outros & 1o. Tri 2010 & $11 / 11 / 2010$ \\
\hline VOL & FIBRIA & FIBR3 & Papel e Celulose & 1o. Tri 2010 & $14 / 05 / 2010$ \\
\hline VOL & GERDAU & GGBR4 & Siderur \& Metalur & 2008 & $15 / 07 / 2009$ \\
\hline VOL & GERDAU MET & GOAU4 & Siderur \& Metalur & 3o. Tri 2007 & $07 / 11 / 2007$ \\
\hline VOL & GOL & GOLL4 & Transporte Serviç & 2008 & 07/05/2009 \\
\hline VOL & GRENDENE SA & GRND3 & Textil & 1o. Tri 2009 & $14 / 05 / 2009$ \\
\hline VOL & $\begin{array}{c}\text { INDÚSTRIAS ROMI } \\
\text { S.A. }\end{array}$ & ROMI3 & Máquinas Indust & 1o. Tri 2009 & $01 / 06 / 2009$ \\
\hline VOL & JBS & JBSS3 & Alimentos e Beb & 1o. Tri 2010 & $14 / 05 / 2010$ \\
\hline VOL & LOJAS RENNER & LREN3 & Comércio & 1o. Tri 2010 & $29 / 04 / 2010$ \\
\hline VOL & LUPATECH S/A & LUPA3 & Siderur \& Metalur & 2009 & $29 / 03 / 2010$ \\
\hline VOL & MARCOPOLO & POMO4 & Veiculos e peças & 1o. Tri 2010 & $10 / 05 / 2010$ \\
\hline VOL & MARISOL SA & MRSL4 & Textil & 1o. Tri 2010 & $22 / 10 / 2010$ \\
\hline
\end{tabular}




\begin{tabular}{lccccc} 
VOL & NATURA & NATU3 & Comércio & 2009 & $08 / 04 / 2010$ \\
VOL & NET S.A. & NETC4 & Outros & 2009 & $26 / 04 / 2010$ \\
VOL & PETROBRAS & PETR4 & Petróleo e Gas & 1o. Tri 2010 & $14 / 05 / 2010$ \\
VOL & SOUZA CRUZ & CRUZ3 & Outros & 2008 & $11 / 02 / 2009$ \\
VOL & TAM S/A & TAMM4 & Transporte Serviç & 2009 & $30 / 06 / 2010$ \\
VOL & TEGMA SA & TGMA3 & Transporte Serviç & 1o. Tri 2010 & $14 / 05 / 2010$ \\
VOL & TELESP & VIVT4 & Telecomunicações & 1o. Tri 2010 & $12 / 05 / 2010$ \\
VOL & TEREOS S/A & TERI3 & Alimentos e Beb & 2o. Tri 2010 & $16 / 08 / 2010$ \\
VOL & TOTVS & TOTS3 & Software e Dados & 1o. Tri 2010 & $29 / 04 / 2010$ \\
VOL & USIMINAS & USIM5 & Siderur \& Metalur & 2009 & $30 / 07 / 2010$ \\
VOL & VALE & VALE5 & Mineração & 1o. Tri 2010 & $05 / 05 / 2010$ \\
VOL & VULCABRAS SA & VULC3 & Textil & 2o. Tri 2010 & $13 / 08 / 2010$ \\
\hline
\end{tabular}

Nota: essa tabela apresenta a amostra antes do corte de empresas do setor Finanças e Seguros, ou seja, corresponde ao subtotal 3 da tabela 3 . As empresas que divulgaram suas demonstrações contábeis full IFRS antes de 31/12/2010 foram consideradas no grupo de adoção antecipada ou voluntária (VOL), seguindo a deliberação n 603 de 2009; os códigos e setores foram obtidos no Economatica; o período de adoção inicial e a data de divulgação das demonstrações contábeis foram definidos a partir de consulta no site da CVM.

APÊNDICE 2 - teste de raiz unitária de Fisher.

Tabela 47 - Teste de raiz unitária de Fisher

\begin{tabular}{lcc}
\hline Variável & Estatística Chi $^{2}$ & p-valor \\
\hline$A T$ & 307,64 & 0,0000 \\
$R E V$ & 236,14 & 0,0000 \\
$E X P$ & 265,22 & 0,0000 \\
$P P E$ & 196,39 & 0,0000 \\
$A D_{K S, G M M}$ & 318,46 & 0,0000 \\
$C F$ & 230,48 & 0,0000 \\
$D E B T$ & 269,03 & 0,0000 \\
$R E T$ & 168,04 & 0,0000 \\
$E A R N$ & 230,77 & 0,0000 \\
$B V$ & 137,13 & 0,0081 \\
$\triangle E A R N$ & 279,93 & 0,0000 \\
SIZE & 264,70 & 0,0000 \\
\hline
\end{tabular}

Nota: resultados do teste de raiz unitária para avaliar a premissa "não correlação das primeiras diferenças defasadas dos regressores endógenos com os erros e os efeitos específicos" do GMM Sistêmico. Utilizou-se o teste de Fisher desenvolvido por Maddala e Wu (1999), cuja hipótese nula implica na existência de raiz unitária. 


\section{ANEXO}

ANEXO 1 - Brazilian Corporate Governance Index - BCGI

Quadro 2 - Brazilian Corporate Governance Index - BCGI Evidenciação

1. A empresa publica suas demonstrações na data exigida pela Lei?

2. A empresa publica suas demonstrações contábeis de acordo com o padrão norte-americano (USGAAP)?

3. A empresa é auditada por uma das grandes empresas internacionais de auditoria?

Composição e Funcionamento dos Conselhos

1. Há sobreposição de cargos na presidência do conselho de administração e presidência da empresa (CEO)?

2. O conselho é composto em sua maioria por insiders?

3. O tamanho do conselho está entre 5 e 9 membros conforme sugestão do IBGC?

4. Os membros do conselho têm mandatos consecutivos de um ano conforme sugerido pelo IBGC?

5. A empresa possui um comitê de auditoria permanente?

6. A empresa possui um conselho fiscal permanente?

Estrutura de Propriedade e Controle

1. Os acionistas controladores possuem menos de 50\% das ações ON?

2. O percentual das ações ordinárias em relação ao total é maior do que $80 \%$ ?

3. A razão entre os direitos do fluxo de caixa e direitos de voto dos controladores é maior do que 1 ?

4. O free float é maior ou igual ao requerido pelo Novo Mercado da BM\&FBOVESPA $(25 \%)$ ?

Direitos dos Acionistas

1. O estatuto da empresa estabelece a arbitragem como forma de resolver os conflitos?

2. O estatuto estabelece direitos de voto adicionais além daqueles exigidos pela Lei?

3. A empresa oferece tag along aos seus acionistas além do que é exigido por Lei?

FONTE: LOPES; WALKER, 2008; LIMA, 2011. 